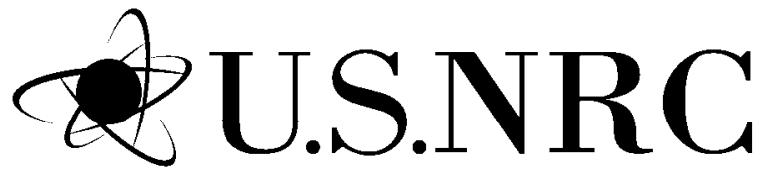

United States Nuclear Regulatory Commission

Protecting People and the Environment

\title{
Crack Growth Rates and Fracture Toughness of Irradiated Austenitic Stainless Steels in BWR Environments
}


United States Nuclear Regulatory Commission

Protecting People and the Environment

\section{Crack Growth Rates and Fracture Toughness of Irradiated Austenitic Stainless Steels in BWR Environments}

Manuscript Completed: December 2006

Date Published: March 2008

Prepared by

O.K. Chopra and W.J. Shack

Argonne National Laboratory

Argonne, IL 60439

S. Crane, NRC Project Manager

NRC Job Code Y6388

Office of Nuclear Regulatory Research 
This page is intentionally left blank. 


\section{Abstract}

In light water reactors, austenitic stainless steels (SSs) are used extensively as structural alloys in reactor core internal components because of their high strength, ductility, and fracture toughness. However, exposure to high levels of neutron irradiation for extended periods degrades the fracture properties of these steels by changing the material microstructure (e.g., radiation hardening) and microchemistry (e.g., radiation-induced segregation). Experimental data are presented on the fracture toughness and crack growth rates (CGRs) of wrought and cast austenitic SSs, including weld heataffected-zone materials, that were irradiated to fluence levels as high as $\approx 2 \times 10^{21} \mathrm{n} / \mathrm{cm}^{2}(\mathrm{E}>1 \mathrm{MeV})$ $(\approx 3 \mathrm{dpa})$ in a boiling heavy water reactor at $288-300^{\circ} \mathrm{C}$. The results are compared with the data available in the literature. The effects of material composition, irradiation dose, and water chemistry on CGRs under cyclic and stress corrosion cracking conditions were determined. A superposition model was used to represent the cyclic CGRs of austenitic SSs. The effects of neutron irradiation on the fracture toughness of these steels, as well as the effects of material and irradiation conditions and test temperature, have been evaluated. A fracture toughness trend curve that bounds the existing data has been defined. The synergistic effects of thermal and radiation embrittlement of cast austenitic SS internal components have also been evaluated.

\section{Paperwork Reduction Act Statement}

This NUREG does not contain information collection requirements and, therefore, is not subject to the requirements of the Paperwork Reduction Act of 1995 (44 U.S.C. 3501 et seq.).

\section{Public Protection Notification}

The NRC may not conduct or sponsor, and a person is not required to respond to, a request for information or an information collection requirement unless the requesting document displays a current valid OMB control number. 
This page is intentionally left blank. 


\section{Foreword}

This report presents the results of a study of simulated light-water reactor coolants, material chemistry, and irradiation damage and their effects on the susceptibility to stress-corrosion cracking of various commercially available and laboratory-melted stainless steels. This report is one of a series dating back about 8 years, describing such results, which are required to support analysis of the structural integrity of reactor internal components, many of which are subject to irradiation-assisted stress-corrosion cracking (IASCC).

The earlier reports detailed crack growth rates in heat-affected zones adjacent to stainless steel weldments, and they comprised the final publications based on specimens irradiated in Phase I (of two) in the Halden test reactor. Phase I irradiations principally involved stainless steels of wide-ranging chemistry (including commercial steels of typical chemistry) and conventional heat treatment and product form processing. By contrast, this report is the first to present data from specimens irradiated in Phase II, which featured a variety of innovatively fabricated and engineered alloys designed to be (possibly) more resistant to IASCC.

Irradiation levels in both Phase I and Phase II ranged up to about 3 displacements per atom (dpa), and the high-temperature water environment used in these tests contained dissolved oxygen concentrations ranging from 200 parts per billion ( $\mathrm{ppb}$ ) to 8 parts per million (ppm). The materials tested included several commonly used stainless steels, such as Types 304 and 316 (and their low-carbon counterparts), as well as CF-8M cast stainless steel. Taken together, these test conditions and materials make the study results most applicable to boiling-water reactor (BWR) internals.

This report presents additional crack growth rate data, which reinforce the earlier observation that when typical stainless steels are irradiated from $>0.75$ to $4.0 \mathrm{dpa}$, the growth rates of stress-corrosion cracks are elevated (by a factor of 2 to 7 ) above the reference line established in Revision 2 of NUREG-0313, "Technical Report on Material Selection and Processing Guidelines for BWR Coolant Pressure Boundary Piping: Final Report," dated January 1988. By contrast, for stainless steels irradiated to $0.45 \mathrm{dpa}$, or not irradiated at all, the growth rates of stress-corrosion cracks are comparable to, or slightly lower than, the NUREG-0313 reference line. Therefore, accumulated irradiation doses above 0.75 dpa can elevate crack growth rates in stainless steels. All tests conducted in simulated hydrogen water chemistry had substantially lower crack growth rates than the NUREG-0313 reference line. This result illustrates the beneficial effect of a low dissolved oxygen environment.

In addition, this report describes initial results of fracture toughness testing of sensitized and irradiated Type 304 stainless steel, heat-affected zone material, and CF-8M. The tests were conducted in simulated BWR environments by applying slowly-rising loads to specimens with stress-corrosion precracks (as opposed to air environment fatigue precracks). This approach is inherently more representative of the presumed failure mode of reactor internal components. However, these initial results exhibited little toughness degradation compared to comparable materials in high-temperature air environments. This finding suggests that the BWR environment may not substantially degrade the fracture toughness of irradiated stainless steels.

In part, the results of this NUREG/CR form the technical basis for Title 10 of the Code of Federal Regulations Part 50.55a (10 CFR 50.55a). In addition, the results of this research, including crack growth rates, may be reviewed, and if applicable, used as a basis for making a decision to approve or deny requests for relief or requests for reductions of inspection requirements of 10 CFR 50.55a. 
This page is intentionally left blank. 


\section{Contents}

Foreword

Contents

vii

Figures..

Tables $\mathrm{XV}$

Executive Summary xvii

Acknowledgments xxi

Acronyms and Abbreviations.

xxiii

Symbols

XXV

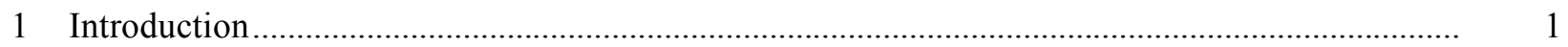

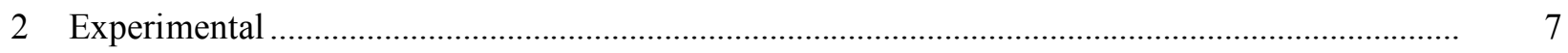

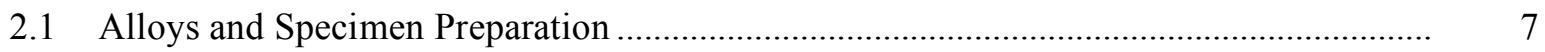

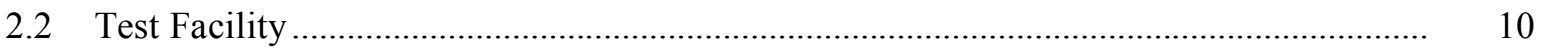

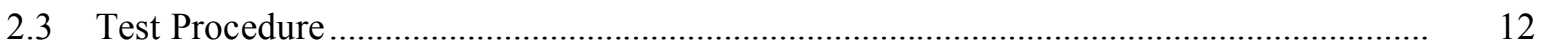

2.3.1 Crack Growth Rate Tests …........................................................................ 12

2.3.2 Fracture Toughness J-R Curve Tests ……...................................................... 16

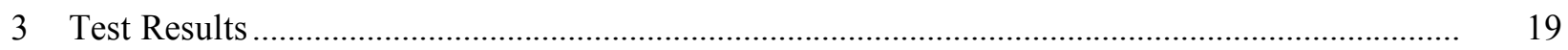

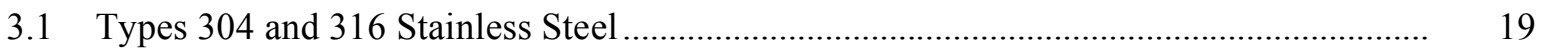

3.1.1 Specimen C21-A of Type 316 SS, Test CGRI-25 ……………………............ 19

3.1.2 Specimen C21-B of Type 316 SS, Test CGRI-24 ............................................. 21

3.1.3 Specimen C21-C of Type 316 SS, Test CGRI-26 ............................................. 24

3.1.4 Specimen 85-3TT of Sensitized Type 304 SS, Test CGRI JR-31 …................ 27

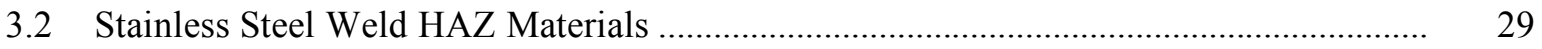


3.2.1 Simulated BWR Environment.

3.2.1.1 Specimen 85-XA of Type 304 SS SMA Weld HAZ, Test CGRI JR-32.

3.2.1.2 Specimen GG6T-A of Type 304L SS SA Weld HAZ, Test CGRI JR-35.

3.2.2 Air Environment.....

3.2.2.1 Specimen 85-XB of Type 304 SS SMA Weld HAZ, Test JRI-35... 36

3.2.2.2 Specimen GG6T-B of Type 304L SS SA Weld HAZ, Test JRI-36 39

3.3 Cast CF-8M Stainless Steel

3.3.1 Specimen 75-11TT of Thermally Aged CF-8M Cast SS, Test CGRI JR-33 ....

3.3.2 Specimen 75-11TM of Thermally Aged CF-8M Cast SS, Test CGRI JR-34 ...

4 Discussion

4.1 CGRs under Constant Load with or without Periodic Partial Unloading

4.1.1 Solution-Annealed Materials

4.1.2 Stainless Steel Weld HAZ Materials

4.1.3 Cast Austenitic Stainless Steel

4.1.4 Comparison with CGR Data in the Literature

4.1.5 Specimen K/Size Criterion

4.2 CGRs under Continuous Cycling.

4.2.1 Solution-Annealed Materials

4.2.2 Stainless Steel Weld HAZ Materials.

4.2.2.1 Air Environment

4.2.2.2 Simulated BWR Environment.

4.2.3 Cast Austenitic Stainless Steels.

4.3 Fracture Toughness of Irradiated Austenitic SSs.

4.3.1 Comparison with Fracture Toughness Data in the Literature... 
4.3.2 Fracture Toughness Trend Curve

4.3.3 Synergistic Effect of Thermal and Neutron Irradiation

5. Summary

References.

Appendix A: Crack Growth Rate Data for Irradiated Austenitic SSs

A-1

Appendix B: Fracture Toughness J-R Curve Data for Irradiated Austenitic SSs

B-1 


\section{Figures}

1. Fracture toughness $J_{I c}$ as a function of neutron exposure for austenitic Types 304 and 316 stainless steels irradiated in fast reactors and BWRs.

2. Susceptibility of irradiated austenitic SSs to IGSCC as a function of fluence in high-DO water.

3. Configuration of compact-tension specimen for this study.

4. Micrographs of the structure of Heat 10285 of Type 304 SS and Type 304L from the top shell of the H5 weld of the GG core shroud.

5. Micrographs of the interface between the weld metal and top shell of the H5 weld of the GG core shroud.

6. Ferrite morphology for the CF-8M cast SS

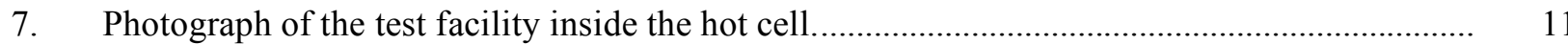

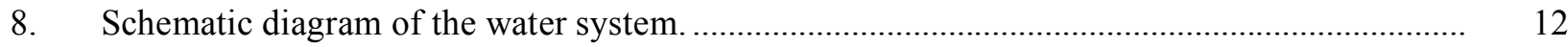

9. Photograph of the fracture surfaces of the two halves of the fractured specimen C21-A.......... 20

10. Crack-length-vs.-time plot for Type $316 \mathrm{SS}$ in $\mathrm{BWR}$ water at $288^{\circ} \mathrm{C}$ during test periods precracking-3, 4-5, and 6-7.

11. Change in crack length and ECP of Pt and SS electrodes during test periods 5-6 and the intermediate transition period.

12. Photomicrographs of the fracture surface of Specimen C21-B.

13. Crack-length-vs.-time plot for Type $316 \mathrm{SS}$ in $\mathrm{BWR}$ water at $288^{\circ} \mathrm{C}$ during test periods precraking-5 and 6-7

14. Change in crack length and ECP of Pt and SS electrodes during test periods 3-5 and 7-9.......

15. Photograph of the fracture surfaces of the two halves of the fractured specimen C21-C.

16. Crack-length-vs.-time plot for Type $316 \mathrm{SS}$ in BWR water at $288^{\circ} \mathrm{C}$ during test periods precracking-3, 4-7, and 8-9.

17. Load vs. load-line displacement curve for sensitized Type 304 SS tested in high-purity water at $289^{\circ} \mathrm{C}$.

18. Photograph of the fracture surface of for sensitized Type 304 SS tested in high-purity water at $289^{\circ} \mathrm{C}$. 
19. Crack-length-vs.-time plots for sensitized and irradiated Type $304 \mathrm{SS}$ in high-purity water at $289^{\circ} \mathrm{C}$ during test periods precracking-2 and 3-4.....

20. Fracture toughness J-R curve for sensitized Type 304 SS irradiated to 2.16 dpa in high-DO water at $289^{\circ} \mathrm{C}$

21. Load vs. load-line displacement curve for Type 304 SS SMA weld HAZ tested in high-purity water at $289^{\circ} \mathrm{C}$.

22. Photograph of the fracture surface of Type 304 SS SMA weld HAZ tested in high-purity water at $289^{\circ} \mathrm{C}$

23. Crack-length-vs.-time plots for irradiated Type 304 SS SMA weld HAZ in high-purity water at $289^{\circ} \mathrm{C}$ during test periods precracking- 2 and $3-4$.

24. Fracture toughness J-R curve for Type 304 SS SMA weld irradiated to 2.16 dpa in high-DO water at $289^{\circ} \mathrm{C}$.

25. Fracture pieces of Type 304 SS SMA weld HAZ: side view and end view.

26. Load vs. load-line displacement curve for Type 304L SS SA weld HAZ tested in high-purity water at $289^{\circ} \mathrm{C}$

27. Photographs of the fracture surface and end view of Type 304L SS SA weld HAZ.

28. Crack-length-vs.-time plot for Type 304L SS SA weld HAZ in BWR water at $289^{\circ} \mathrm{C}$ for test periods precracking-5 and 6-9.

29. Fracture toughness J-R curve for Type 304L SS SA weld HAZ material in high-DO water at $289^{\circ} \mathrm{C}$.

30. Load vs. load-line displacement curve for Type 304 SS SMA weld HAZ tested in air at $289^{\circ} \mathrm{C}$.

31. Photograph of the fracture surface of the two halves of Type 304 SS SMA weld HAZ.

32. Crack-length-vs.-time plots for irradiated Type $304 \mathrm{SS}$ SMA weld HAZ in air at $289^{\circ} \mathrm{C}$ during test periods precracking-2 and 3-4.

33. Photograph of the side view of the two halves of Type 304 SS SMA weld HAZ.

34. Photograph of the end view of the two halves of Type 304 SS SMA weld HAZ.

35. Fracture toughness J-R curve for Type 304 SS SMA weld HAZ irradiated to 2.16 dpa tested in air and $\mathrm{NWC} \mathrm{BWR}$ water at $289^{\circ} \mathrm{C}$.

36. Load vs. load-line displacement curve for Type 304L SS SA weld HAZ tested in air at $289^{\circ} \mathrm{C}$ 
37. Photograph of the fracture surface of Type 304L SS SA weld HAZ tested in air at $289^{\circ} \mathrm{C} \ldots \ldots .$.

38. Fracture pieces of Type 304L SS SA weld HAZ: side view and end view.

39. Crack-length-vs.-time plot for Type $304 \mathrm{~L} \mathrm{SS} \mathrm{SA}$ weld $\mathrm{HAZ}$ in air at $289^{\circ} \mathrm{C}$ from precracking to test period 4 .

40. Fracture toughness J-R curve for Type 304L SS SA weld HAZ irradiated to 2.16 dpa tested in air at $289^{\circ} \mathrm{C}$.

41. Load vs. load-line displacement curve for CF-8M cast SS tested in high-purity water.

42. Photographs of the fracture surface of the two halves of CF-8M cast SS.

43. Side view of the fractured pieces of CF-8M cast SS.

44. Crack-length-vs.-time plot for CF-8M cast SS in BWR water at $289^{\circ} \mathrm{C}$ for test periods precracking-3, 3-5, and 6-7.

45. Fracture toughness J-R curve for thermally aged and irradiated cast CF-8M SS in high-DO water at $289^{\circ} \mathrm{C}$.

46. Load vs. load-line displacement curve for CF-8M cast SS tested in high-purity water.

47. Photographs of the fracture surface and end view of the two halves of CF-8M cast SS.

48. Crack-length-vs.-time plot for CF-8M cast SS in BWR water at $289^{\circ} \mathrm{C}$ for test periods precracking-3, 3-5, and 6-7.

49. Fracture toughness J-R curve for thermally aged and irradiated cast CF-8M SS in high-DO water at $289^{\circ} \mathrm{C}$.

50. CGR data under constant load with periodic partial unloads for irradiated austenitic SSs in high-purity water at $289^{\circ} \mathrm{C}$.

51. Crack growth rates under constant load for irradiated Heat C21 of Type 316 SS in NWC and HWC BWR environments at $289^{\circ} \mathrm{C}$.

52. CGR under constant load with periodic partial unloads for nonirradiated and irradiated SS weld $\mathrm{HAZ}$ specimens in high-purity water at $289^{\circ} \mathrm{C}$.

53. CGR under constant load for thermally aged and irradiated CF-8M cast stainless steel specimens in BWR environment at $289^{\circ} \mathrm{C}$.

54. CGR under constant load in NWC and HWC BWR environments at $289^{\circ} \mathrm{C}$ for austenitic stainless steels irradiated to $0.75-2.2 \mathrm{dpa}$.

55. CGR under constant load in NWC and HWC BWR environments at $289^{\circ} \mathrm{C}$ for austenitic stainless steels irradiated to 3.0-4.0 dpa. 
56. CGR under constant load in BWR environment at $289^{\circ} \mathrm{C}$ for austenitic stainless steels irradiated to $<0.5 \mathrm{dpa}$ and $\approx 13.0 \mathrm{dpa}$.

57. CGR under constant load in NWC and HWC BWR environments for austenitic stainless steels irradiated to 1.0-2.5 dpa, 3.0-4.0 dpa, and $13 \mathrm{dpa}$, plotted as a function of the steel ECP.

58. Experimental CGRs for irradiated austenitic stainless steels obtained in high- and low-DO BWR environments under loading conditions that exceeded the $\mathrm{K} /$ size criterion.

59. Crack length and $\mathrm{K}_{\max }$ vs. time for Type 304L SS Specimen C3-C in high-purity water at $289^{\circ} \mathrm{C}$ during test periods 6 and 7.

60. Side view of the first slice cut from Type 304L SS Specimen C3-C.

61. A photograph of the entire crack extension for the first slice of Type 304L SS Specimen C3$\mathrm{C}$ and high-magnification micrographs of the surface at locations 2 and 1.

62. Photograph of the fracture surface of the second slice of Type 304L SS Specimen C3-C and high-magnification micrographs of the surface at locations D, C, B, and A.

63. Engineering stress vs. strain curve for Type 304 stainless steel irradiated to $3.0 \mathrm{dpa}$ and tested in air at 289 and $325^{\circ} \mathrm{C}$.

64. Strain distribution of a moving crack in a strain-softening and a strain-hardening material......

65. CGR for irradiated specimens of austenitic SSs under continuous cycling at $289^{\circ} \mathrm{C}$ in highpurity water with $\approx 300 \mathrm{ppb}$ and $<30 \mathrm{ppb}$ dissolved oxygen.

66. CGR data under cyclic loading for irradiated SS weld HAZ materials in air and high-purity water at $289^{\circ} \mathrm{C}$.

67. CGR data under cyclic loading for nonirradiated SS weld HAZ materials in high-purity water at $289^{\circ} \mathrm{C}$.

68. CGR for irradiated specimens of Type 304L SA weld HAZ from the Grand Gulf core shroud and laboratory-prepared Type 304 SS SMA weld HAZ under continuous cycling in highpurity water at $289^{\circ} \mathrm{C}$.

69. CGR data under cyclic loading for irradiated CF-8M cast austenitic SS in high-purity water at $289^{\circ} \mathrm{C}$.

70. Change in fracture toughness $\mathrm{J}_{\mathrm{Ic}}$ as a function of neutron exposure for irradiated austenitic SSs.

71. J-R curves for irradiated Type $304 \mathrm{SS}$ and thermally aged CF-8M cast SS at $289^{\circ} \mathrm{C}$.

72. J-R curves for irradiated specimens of Type 304 SS SMA weld HAZ and Type 304L SA weld HAZ in air and BWR water environments. 
73. The change in initiation toughness $\mathrm{J}_{\mathrm{Ic}}$ of wrought austenitic SSs and cast austenitic SSs and weld metals as a function of neutron exposure.

74. Fracture toughness $\mathrm{J}_{\mathrm{Ic}}$ of irradiated austenitic stainless steels and welds as a function of test temperature.

75. The change in coefficient $\mathrm{C}$ of the power-law J-R curve for wrought austenitic SSs and cast austenitic SSs and weld metals as a function of neutron exposure.

76. Experimental values of J-integral at a crack extension of $2.5 \mathrm{~mm}$ for wrought austenitic SSs and cast austenitic SSs and weld metals plotted as a function of neutron exposure.

A1. Photograph of the fracture surfaces of the two halves of the fractured Specimen C3-A.

A2. Photomicrographs of the fracture surface of Specimen C3-B.

A3. Photograph of the fracture surfaces of the two halves of the fractured Specimen C3-C.

A4. Photograph of the fracture surfaces of the two halves of the fractured Specimen C16-B.

A5. Photomicrograph of the fracture surface of Specimen GG5B-A

A6. Photomicrographs of the fracture surfaces of the two halves of Specimen 85-3A-TT.

A7. Micrograph of the fracture surface of Specimen GG3B-A-TT tested in high-DO water at $289^{\circ} \mathrm{C}$.

A8. Micrograph of the fracture surface of Specimen 85-YA tested in BWR environment at $289^{\circ} \mathrm{C}$.

A9. Photomicrograph of the fracture surface of Specimen GG5T-B.

A10. Photomicrograph of the fracture surface of Specimen 85-1A TT.

A11. Photomicrograph of the fracture surface of Specimen 85-7A. 


\section{Tables}

1. Composition of austenitic stainless steels being investigated..................................................... 8

2. Tensile properties at $289^{\circ} \mathrm{C}$ of austenitic stainless steels from Halden Phase I irradiations....... $\quad 10$

3. Tensile properties at $289^{\circ} \mathrm{C}$ of austenitic stainless steels from Halden Phase II irradiations..... $\quad 10$

4. Test conditions and results for Specimen C21-A of Type $316 \mathrm{SS}$ in BWR water at $289^{\circ} \mathrm{C} . \ldots . . \quad 20$

5. Test conditions and results for Specimen C21-B of Type 316 SS in BWR water at $289^{\circ} \mathrm{C} \ldots \ldots . .23$

6. Test conditions and results for Specimen C21-C of Type 316 SS in BWR water at $289^{\circ} \mathrm{C} \ldots \ldots . .25$

7. Test conditions and results for Specimen 85-3TT of sensitized Type 304 SS in high-purity

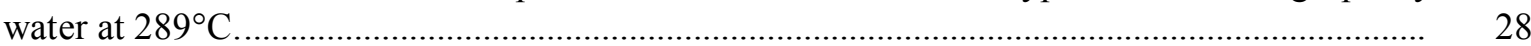

8. Test conditions and results for Specimen 85-XA of Type 304 SS SMA weld HAZ in highpurity water at $289^{\circ} \mathrm{C}$.

9. Test conditions and results for Type 304L SS SA weld HAZ specimen GG6T-A in BWR water at $289^{\circ} \mathrm{C}$

10. Test conditions and results for Type 304 SMA weld $\mathrm{HAZ}$ specimen $85-\mathrm{XB}$ in air at $289^{\circ} \mathrm{C} \ldots$.

11. Test conditions and results for Type 304L SA weld HAZ specimen GG6T-B in air at $289^{\circ} \mathrm{C}$..

12. Test conditions and results for thermally aged CF-8M Specimen 75-11TT in BWR water at $289^{\circ} \mathrm{C}$.

13. Test conditions and results for thermally aged CF-8M Specimen 75-11TM in BWR water at $289^{\circ} \mathrm{C}$.

14. Test conditions and constant-load crack growth data in BWR environment at $289^{\circ} \mathrm{C}$

15. The cyclic crack growth data in BWR environment at $289^{\circ} \mathrm{C}$

16. Screening criteria for thermal-aging susceptibility of cast austenitic stainless steels.

17. Cyclic CGR correlations for wrought and cast austenitic stainless steels in BWR environments at $289^{\circ} \mathrm{C}$.

A1. Crack growth data for Specimen C3-A of Type 304L SS in BWR water at $289^{\circ} \mathrm{C}$

A2. Crack growth data for Specimen C3-B of Type 304L SS in BWR water at $289^{\circ} \mathrm{C}$.

A3. Crack growth data for Specimen C3-C of Type 304L SS in BWR water at $289^{\circ} \mathrm{C}$. 
A4. Crack growth data for Specimen C16-B of Type $316 \mathrm{~L} \mathrm{SS}$ in BWR water at $289^{\circ} \mathrm{C}$.

A5. Crack growth results for Specimen GG5B-A of Type 304L HAZ in high-purity water at $289^{\circ} \mathrm{C}$.

A6. Crack growth results for Specimen 85-3A-TT of nonirradiated Type 304 SS SMA weld HAZ in high-purity water at $289^{\circ} \mathrm{C}$.

A7. Cr A-ack growth results for Specimen GG3B-A-TT of Type 304L HAZ in high-purity water at $289^{\circ} \mathrm{C}$.

A8. Crack growth results for Specimen 85-YA of nonirradiated Type 304 SS SMA weld HAZ in high-purity water at $289^{\circ} \mathrm{C}$.

A9. Crack growth results for Specimen GG5T-A of Type 304L HAZ in high-purity water at $289^{\circ} \mathrm{C}$.

A10. Crack growth results for Specimen GG5T-B of Type 304L HAZ in high-purity water at $289^{\circ} \mathrm{C}$.

A11. Crack growth results for Specimen 85-1A-TT of Type 304 SS SMA weld HAZ in highpurity water at $289^{\circ} \mathrm{C}$.

A12. Crack growth data for specimen 85-7A of SS SMA Weld HAZ in high-purity water at $289^{\circ} \mathrm{C}$.

B1. Fracture toughness data for specimen $\mathrm{C} 19-\mathrm{A}$ in air at $289^{\circ} \mathrm{C}$.

B2. Fracture toughness data for specimen C19-B in air at $289^{\circ} \mathrm{C}$.

B3. Fracture toughness data for specimen $\mathrm{C} 19-\mathrm{C}$ in air at $289^{\circ} \mathrm{C}$.

B4. Fracture toughness data for specimen $\mathrm{C} 16-\mathrm{A}$ in air at $289^{\circ} \mathrm{C}$

B5. Fracture toughness data for specimen $85-3 \mathrm{TT}$ in high-purity water at $289^{\circ} \mathrm{C}$.

B6. Fracture toughness data for specimen 85 -XA in high-purity water at $289^{\circ} \mathrm{C}$

B7. Fracture toughness data for specimen GG6T-A in high-purity water at $289^{\circ} \mathrm{C}$.

B8. Fracture toughness data for specimen $85-\mathrm{XB}$ in air at $289^{\circ} \mathrm{C}$.

B9. Fracture toughness data for specimen GG6T-B in air at $289^{\circ} \mathrm{C}$.

B10. Fracture toughness data for specimen $75-11 \mathrm{TT}$ in high-purity water at $289^{\circ} \mathrm{C}$. 


\section{Executive Summary}

\section{Background}

In light water reactors (LWRs), austenitic stainless steels (SSs) are used extensively as structural alloys in the internal components of reactor pressure vessels because of their relatively high strength, ductility, and fracture toughness. However, exposure to neutron irradiation for extended periods changes the microstructure and degrades the fracture properties of these steels. Irradiation leads to a significant increase in yield strength and reduction in ductility and fracture resistance of austenitic SSs. Although radiation embrittlement was not considered in the design of LWR core internal components constructed of austenitic SSs, it has become an important consideration in addressing nuclear plant aging and license renewal issues. Also, irradiation exacerbates the corrosion fatigue and stress corrosion cracking (SCC) behavior of SSs by affecting the material microchemistry (e.g., radiation-induced segregation); material microstructure (e.g., radiation hardening); and water chemistry (e.g., radiolysis).

The factors that influence SCC susceptibility of materials include neutron fluence, cold work, corrosion potential, water purity, temperature, and loading. Although a threshold fluence level of $5 \times 10^{20} \mathrm{n} / \mathrm{cm}^{2}(\mathrm{E}>1 \mathrm{MeV})(\approx 0.75 \mathrm{dpa})$ is often assumed for austenitic SSs in the boiling water reactor (BWR) environment, experimental data show that increases in susceptibility to intergranular cracking can occur at fluences greater than $\approx 2 \times 10^{20} \mathrm{n} / \mathrm{cm}^{2}(\mathrm{E}>1 \mathrm{MeV})(\approx 0.3 \mathrm{dpa})$. At low enough fluences, reducing the corrosion potential of the environment has proved beneficial. However, low corrosion potential does not always provide immunity to irradiation-assisted stress corrosion cracking (IASCC). For example, intergranular SCC has occurred in cold-worked, irradiated SS baffle bolts in pressurized water reactors (PWRs) where the corrosion potential is very low.

\section{Test Program}

A program is being conducted at Argonne National Laboratory (ANL) on irradiated SSs to better understand the cracking of BWR core internal components. The susceptibility of austenitic SSs to IASCC and the resulting crack growth rates (CGRs) are being evaluated as a function of the fluence level, material composition, and water chemistry. The effect of neutron irradiation on the fracture toughness of wrought and cast austenitic SSs is also being evaluated.

Crack growth and fracture toughness tests have been completed on irradiated wrought and cast austenitic SSs, including weld heat-affected-zone (HAZ) materials, in BWR environments at $289^{\circ} \mathrm{C}$. The present report presents experimental data on Type $316 \mathrm{SS}$ irradiated to $0.3,0.9$, and $2.0 \times 10^{21} \mathrm{n} / \mathrm{cm}^{2}$ $(0.45,1.35$, and $3.0 \mathrm{dpa})$; sensitized Type $304 \mathrm{SS}$ and SS weld HAZ materials irradiated to $1.44 \times 10^{21} \mathrm{n} / \mathrm{cm}^{2}(2.16 \mathrm{dpa})$; and thermally aged CF-8M cast SS irradiated to $1.63 \times 10^{21} \mathrm{n} / \mathrm{cm}^{2}$ ( $2.46 \mathrm{dpa})$. The CGR tests on materials irradiated to 2.16 or $2.46 \mathrm{dpa}$ were followed by a fracture toughness J-R curve test in the BWR environment. Tests have also been conducted in air at $289^{\circ} \mathrm{C}$ to obtain baseline data. Also compiled in this report are crack growth and fracture toughness data from earlier ANL studies on Types 304L and 316L SS irradiated up to 3.0 dpa and SS weld HAZ materials irradiated to $0.75 \mathrm{dpa}$ in BWR environments, as well as fracture toughness data on Types 304 and $316 \mathrm{~L}$ $\mathrm{SS}$ irradiated up to $3.0 \mathrm{dpa}$ in air at $289^{\circ} \mathrm{C}$. The results from the $\mathrm{ANL}$ studies are compared with the data available in the literature. 


\section{Crack Growth Rate Tests}

The test results indicate that in normal water chemistry (NWC) BWR environment, the SCC CGRs of nonirradiated SSs or materials irradiated to $\approx 3 \times 10^{20} \mathrm{n} / \mathrm{cm}^{2}(\approx 0.45 \mathrm{dpa})$ are either comparable to or slightly lower than the disposition curve in NUREG-0313 for sensitized SSs in water with 8 ppm dissolved oxygen (DO). Neutron irradiation to higher dpa increases the growth rates significantly. The SCC CGRs of SSs irradiated to $5 \times 10^{20}-2.67 \times 10^{21} \mathrm{n} / \mathrm{cm}^{2}(0.75-4.0 \mathrm{dpa})$ are a factor of 2-7 higher than the NUREG-0313 disposition curve. For the same irradiation level, the CGRs for weld HAZ materials were higher than those for solution-annealed SSs. Results in the literature suggest that the CGRs of SSs irradiated to higher fluence levels (e.g., $8.67 \times 10^{21} \mathrm{n} / \mathrm{cm}^{2}$ or $13 \mathrm{dpa}$ ) strongly depend on the stress intensity factor $(\mathrm{K})$ and can be up to a factor of 30 higher than the NUREG-0313 disposition curve.

The results for nonirradiated SSs and steels irradiated up to $2.67 \times 10^{21} \mathrm{n} / \mathrm{cm}^{2}(4.0 \mathrm{dpa})$ indicate a benefit from a low-DO environment. The SCC CGRs were decreased more than an order of magnitude when the environment was changed from a NWC BWR environment to hydrogen water chemistry (HWC) environment. It is known that at very high fluence levels, the beneficial effect of HWC is lost. The question of the maximum fluence level at which HWC is effective is of obvious importance. In our tests, a few specimens with less than 4.0 dpa did not show the benefit of the low-DO environment at higher values of $\mathrm{K}$ (greater than $20 \mathrm{MPa} \mathrm{m}^{1 / 2}$ ). Because the loading conditions exceeded the proposed "effective yield stress" K/size criterion for irradiated SSs, it is not clear whether the specimen constraint had been lost for these tests. However, the adequacy of the current proposed K/size criterion is not well established, and the possible effects of a loss of specimen constraint on fracture morphology and crack growth behavior are discussed.

Although the data are limited, tests on SS weld HAZ materials indicate that neutron irradiation to $\approx 2.2$ dpa has little or no effect on cyclic CGRs in air. The experimental CGRs are, in fact, slightly lower than those predicted by the previously published correlations for solution-annealed SSs.

In an NWC BWR environment, the cyclic CGRs of wrought SSs irradiated to $\approx 3 \times 10^{20} \mathrm{n} / \mathrm{cm}^{2}$ $(\approx 0.45 \mathrm{dpa})$ are the same as those for nonirradiated materials, whereas the cyclic CGRs of SSs irradiated to $5 \times 10^{20}-2.67 \times 10^{21} \mathrm{n} / \mathrm{cm}^{2}(0.75-4.0 \mathrm{dpa})$ are higher. Limited data suggest that the growth rates of irradiated CF-8M cast SS are lower than those of solution-annealed materials irradiated to the same fluence level. At low frequencies, cyclic CGRs are decreased by more than an order of magnitude when the DO level is decreased by changing from NWC to HWC. A superposition model was used to represent the cyclic CGRs of austenitic SSs. The CGR in the BWR environments can be expressed as the superposition of the rate in air (mechanical fatigue) and the rates due to corrosion fatigue and SCC.

\section{Fracture Toughness Tests}

Neutron irradiation also decreases the fracture toughness of wrought and cast austenitic SSs and SS weld HAZ materials. For the same irradiation conditions, the fracture toughness of thermally aged cast SS is lower than that of HAZ material, which, in turn, is lower than that of solution-annealed materials. Limited data on irradiated SS weld HAZ materials indicate that an NWC BWR environment has little or no effect on the fracture toughness J-R curves of these materials (i.e., the fracture toughness J-R curves in air and NWC BWR environments are comparable). However, additional tests are needed to investigate the possible effects of LWR coolant environments on fracture toughness, e.g., the effect of the corrosion/ oxidation reaction during crack extension or using specimens with an intergranular crack rather than the transgranular fatigue crack generally used in nearly all fracture toughness tests. 
The available fracture toughness data in the open literature on wrought and cast austenitic SSs and their welds have been reviewed. The data were analyzed to determine the effect of neutron irradiation on the fracture toughness of these steels, as well as the effect of material and irradiation conditions and test temperature. Most of the experimental data on neutron embrittlement of austenitic SSs are from materials irradiated in high flux fast reactors. Test results under irradiation conditions that are characteristic of LWRs, beyond those discussed in this report, are very limited. However, although the irradiation conditions differ, in general, the data trends to first order appear to be similar for the fast reactor and LWR irradiations.

The fracture toughness data on austenitic SSs indicate little or no change in toughness below $0.5 \mathrm{dpa}$, then a rapid decrease in toughness between 1 and 5 dpa to reach a saturation toughness value, and no further change beyond $10 \mathrm{dpa}$. There appear to be no significant differences in the fracture toughness data trends for the various grades of wrought austenitic SSs. For nonirradiated materials, it is wellestablished that the fracture toughness of weld metals and thermally aged cast SSs is lower than that of wrought materials. The fracture toughness of these materials also decreases more rapidly with irradiation than does that of wrought steels.

The data have been evaluated to define (a) a threshold neutron exposure for radiation embrittlement of austenitic SSs and a minimum fracture toughness of austenitic SSs irradiated to less than the threshold value, (b) a saturation irradiation level and saturation fracture toughness, and (c) a bounding curve for the changes in fracture toughness between the threshold and saturation irradiation levels. The results indicate that the fracture toughness properties exhibit (a) a threshold irradiation level of $\approx 0.3$ dpa below which irradiation has little or no effect on fracture toughness and (b) a saturation irradiation level of $\approx 5$ dpa. Conservatively, no ductile crack extension is assumed to occur at or above the saturation irradiation level. The available data indicate a $J$ value for the onset of crack extension $\left(J_{I c}\right)$ of $15 \mathrm{~kJ} / \mathrm{m}^{2}\left(86 \mathrm{in} .-1 \mathrm{~b} / \mathrm{in} .{ }^{2}\right)$ for austenitic SSs irradiated to $5 \mathrm{dpa}$. A fracture toughness trend curve that bounds the existing data has been derived in terms of $\mathrm{J}_{\mathrm{Ic}}$ vs. neutron dose as well as the coefficient $\mathrm{C}$ of the power-law J-R curve vs. dose.

The synergistic effects of thermal and radiation embrittlement of cast austenitic SS internal components have also been evaluated. Cast austenitic SSs have a duplex structure consisting of both ferrite and austenite phases and are susceptible to thermal embrittlement even in the absence of irradiation. Thermal aging affects primarily the ferrite phase and has little or no effect on the austenite phase. Below $2 \times 10^{20} \mathrm{n} / \mathrm{cm}^{2}(0.3 \mathrm{dpa})$, the minimum fracture toughness can be estimated from the correlations available for thermal embrittlement of cast SS. For fluences $>2 \times 10^{20} \mathrm{n} / \mathrm{cm}^{2}(>0.3 \mathrm{dpa})$, the minimum fracture toughness of cast SSs can be assumed to be given by the lesser of the minimum predicted toughness for thermal aging or the lower bound curves for the fracture toughness of irradiated stainless steels. 
This page is intentionally left blank. 


\section{Acknowledgments}

The authors thank T. M. Karlsen, OECD Halden Reactor Project, Halden, Norway, for specimen irradiations in the Halden reactor; D. O. Pushis for specimen retrieval; L. A. Knoblich, E. E. Gruber, Y. Chen, and R. Clark for their contributions to the experimental effort; and B. A. Alexandreanu and A. G. Hins for fractographic examination by scanning electron microscopy. This work is sponsored by the Office of Nuclear Regulatory Research, U.S. Nuclear Regulatory Commission, under Job Code Y6388; Program Manager: S. Crane. 
This page is intentionally left blank. 


\section{Acronyms and Abbreviations}

$\begin{array}{ll}\text { ANL } & \text { Argonne National Laboratory } \\ \text { ASTM } & \text { American Society for Testing and Materials } \\ \text { BWR } & \text { Boiling Water Reactor } \\ \text { CGR } & \text { Crack Growth Rate } \\ \text { CT } & \text { Compact Tension } \\ \text { CW } & \text { Cold Worked } \\ \text { DC } & \text { Direct Current } \\ \text { DO } & \text { Dissolved Oxygen } \\ \text { dpa } & \text { Displacements per atom } \\ \text { ECP } & \text { Electrochemical Potential } \\ \text { EPFM } & \text { Elastic-Plastic Fracture Mechanics } \\ \text { EPRI } & \text { Electric Power Research Institute } \\ \text { GG } & \text { Grand Gulf } \\ \text { GTA } & \text { Gas Tungsten Arc } \\ \text { HAZ } & \text { Heat-Affected Zone } \\ \text { HWC } & \text { Hydrogen Water Chemistry } \\ \text { IASCC } & \text { Irradiation-Assisted Stress Corrosion Cracking } \\ \text { IG } & \text { Intergranular } \\ \text { J-R } & \text { J Integral Resistance } \\ \text { LEFM } & \text { Linear-Elastic Fracture Mechanics } \\ \text { LWR } & \text { Light Water Reactor } \\ \text { MA } & \text { Mill Annealed } \\ \text { NDT } & \text { Nil-Ductility Transition } \\ \text { NRC } & \text { Nuclear Regulatory Commission } \\ \text { NWC } & \text { Normal Water Chemistry } \\ \text { PWR } & \text { Pressurized Water Reactor } \\ \text { RIS } & \text { Radiation-Induced Segregation } \\ \text { SA } & \text { Submerged Arc } \\ \text { SCC } & \text { Stress Corrosion Cracking } \\ \text { SHE } & \text { Standard Hydrogen Electrode } \\ \text { SMA } & \text { Shielded Metal Arc } \\ \text { SS } & \text { Stainless Steel } \\ \text { TG } & \text { Transgranular } \\ & \end{array}$


This page is intentionally left blank. 


\section{Symbols}

\begin{tabular}{|c|c|}
\hline a & Crack length \\
\hline$a_{i}$ & Current value of crack length \\
\hline$\dot{\mathrm{a}}_{\text {air }}$ & Crack growth rate in air \\
\hline$\dot{\mathrm{a}}_{\mathrm{env}}$ & Crack growth rate in the environment \\
\hline$\dot{\mathrm{a}}_{\mathrm{scc}}$ & Stress corrosion crack growth rate \\
\hline$A_{p l}$ & Plastic area under the load versus load-line displacement curve \\
\hline $\mathrm{b}$ & Remaining ligament (distance from the physical crack front to the back edge of the specimen) \\
\hline $\mathrm{B}$ & Specimen thickness \\
\hline $\mathrm{B}_{\mathrm{N}}$ & Net specimen thickness \\
\hline da & Increment in crack length \\
\hline $\mathrm{d} J$ & Increment in $\mathrm{J}$ integral \\
\hline $\mathrm{E}$ & Elastic modulus \\
\hline $\mathrm{J}$ & $\begin{array}{l}\mathrm{J} \text { integral, a mathematical expression used to characterize the local stress-strain field at the } \\
\text { crack tip region (parameter J represents the driving force for crack propagation) }\end{array}$ \\
\hline $\mathrm{J}_{\mathrm{el}}$ & Elastic component of $\mathrm{J}$ \\
\hline $\mathrm{J}_{\mathrm{pl}}$ & Plastic component of $\mathrm{J}$ \\
\hline $\mathrm{J}_{\mathrm{Ic}}$ & Value of $\mathrm{J}$ near the onset of crack extension \\
\hline $\mathrm{K}$ & Stress intensity factor \\
\hline $\mathrm{K}_{\max }$ & Maximum stress intensity factor \\
\hline $\mathrm{K}_{\min }$ & Minimum stress intensity factor \\
\hline $\mathrm{P}$ & Applied load \\
\hline $\mathrm{P}_{\max }$ & Maximum applied load \\
\hline $\mathrm{P}_{\min }$ & Minimum applied load \\
\hline $\mathrm{R}$ & load ratio \\
\hline $\mathrm{T}$ & Tearing modulus \\
\hline $\mathrm{t}_{\mathrm{r}}$ & Rise time \\
\hline $\mathrm{U}$ & Current value of DC potential \\
\hline $\mathrm{U}_{0}$ & Initial value of DC potential \\
\hline $\mathrm{V}$ & Total load-line displacement \\
\hline $\mathrm{V}_{\mathrm{pl}}$ & Plastic component of loadline displacement \\
\hline $\mathrm{W}$ & Specimen width \\
\hline$\sigma_{\mathrm{f}}$ & Flow stress, defined as the average of yield and ultimate stress \\
\hline$\sigma_{\mathrm{u}}$ & Ultimate stress \\
\hline$\sigma_{\mathrm{y}}$ & Yield stress \\
\hline$v$ & Poisson ratio \\
\hline
\end{tabular}


This page is intentionally left blank. 


\section{Introduction}

In light water reactors (LWRs), austenitic stainless steels (SSs) are used extensively as structural alloys in the internal components of reactor pressure vessels because of their high strength, ductility, and fracture toughness. Fracture of these steels occurs by stable tearing at stresses well above the yield stress, and tearing instabilities require extensive plastic deformation. However, exposure to neutron irradiation for extended periods changes the microstructure and degrades the fracture properties of these steels. ${ }^{1-4}$ Radiation embrittlement was not considered in the design of LWR core internal components constructed of austenitic SSs, but it is considered in addressing nuclear plant aging and license renewal issues. In addition to irradiation embrittlement, irradiation-assisted stress corrosion cracking (IASCC) is another degradation process that affects LWR internal components exposed to fast neutron radiation, $1,5,6$ and needs to be considered in addressing nuclear plant aging and license renewal issues.

Neutron irradiation of austenitic SSs can produce damage by displacing atoms from their lattice position. This displacement creates point defects such as vacancies and interstitials. These point defects are unstable, and most of them are annihilated by recombination. The surviving defects rearrange into more stable configurations such as dislocation loops, network dislocations, precipitates, and cavities (or voids). Changes in the microstructure of austenitic SSs due to neutron irradiation vary with the irradiation temperature, neutron fluence, flux, and energy spectrum.

At temperatures below $300^{\circ} \mathrm{C}\left(572^{\circ} \mathrm{F}\right)$, neutron irradiation leads to the formation of a substructure with very fine defects that consist primarily of small $(<5 \mathrm{~nm})$ vacancy and interstitial loops ("black spots") and larger $(>5 \mathrm{~nm})$ faulted interstitial loops. ${ }^{7-9}$ At irradiation temperatures above $300^{\circ} \mathrm{C}\left(572^{\circ} \mathrm{F}\right)$, the microstructure consists of larger faulted loops, network dislocations, and cavities that are threedimensional clusters (voids) of vacancies and/or gas bubbles. The microchemistry of the material is also changed due to radiation-induced segregation (RIS). Regions that act as sinks for the point defects that are created by neutron irradiation are enriched with $\mathrm{Ni}$, $\mathrm{Si}$, and $\mathrm{P}$, and depleted in $\mathrm{Cr}$ and Mo. Such changes in microchemistry can result in the formation of various precipitates. Cavities are often associated with these precipitates, as well as dislocations and grain boundaries.

The point defect clusters and precipitates act, to varying extent, as obstacles to a dislocation motion that leads to matrix strengthening, resulting in an increase in tensile strength and a reduction in ductility and fracture toughness of the material. In general, cavities (or voids) are strong barriers, large faulted Frank loops are intermediate barriers, and small loops and bubbles are weak barriers to dislocation motion. ${ }^{1}$ For austenitic SSs, the greatest increase in yield strength for a given irradiation level occurs at irradiation temperatures near $300^{\circ} \mathrm{C}\left(572^{\circ} \mathrm{F}\right)$, which is in the temperature range of LWR operation. In boiling water reactors (BWRs), the temperature of core internal components is nearly constant at $\approx 288^{\circ} \mathrm{C}$ $\left(550^{\circ} \mathrm{F}\right)$. Most pressurized water reactor (PWR) core internals operate nominally at $\approx 300^{\circ} \mathrm{C}\left(572^{\circ} \mathrm{F}\right)$, the temperature where the rate of increase in yield strength with irradiation is the greatest.

As the yield strength approaches the ultimate strength of the material, deformation by a planar slip mechanism is promoted. 10 This process is also termed "dislocation channeling," whereby dislocation motion along a narrow band of slip planes clears the irradiation-induced defect structure, creating a defect-free channel that offers less resistance to subsequent dislocation motion or deformation. The enhanced planar slip leads to a pronounced degradation in the fracture toughness of austenitic SSs. ${ }^{3}$ Such effects of irradiation on the fracture toughness of austenitic SSs appear to be strongly influenced by minor differences in the chemical composition of the steels; ${ }^{1}$ the chemical composition can influence the 
stacking fault energy and/or irradiation-induced microstructure. In general, a higher stacking-fault energy enhances, and cold work inhibits, dislocation channeling. ${ }^{1}$

As discussed above, neutron irradiation can decrease the fracture toughness of austenitic SSs significantly, and failure may occur without general yielding. In such instances, a fracture mechanics methodology such as elastic-plastic fracture mechanics (EPFM) or linear-elastic fracture mechanics (LEFM) is needed for analysis of structural integrity and development of inspection guidelines. The former involves the $\mathrm{J}$ integral-resistance $(\mathrm{J}-\mathrm{R})$ curve approach and is used where failure involves plastic deformation. The $J$ integral is a mathematical expression used to characterize the local stress-strain field at the crack tip region (parameter $\mathrm{J}$ represents the driving force for crack propagation), and the $\mathrm{J}-\mathrm{R}$ curve characterizes the resistance of the material to stable crack extension. The fracture toughness of such materials is represented by fracture mechanics parameters such as $\mathrm{J}_{\mathrm{Ic}}$, the value of $\mathrm{J}$ near the onset of crack extension, and the tearing modulus, T, which characterizes the slope of the J-R curve:

$$
\mathrm{T}=\frac{\mathrm{dJ}}{\mathrm{da}} \frac{\mathrm{E}}{\sigma_{\mathrm{f}}^{2}},
$$

where $\mathrm{E}$ is the elastic modulus, $\mathrm{a}$ is the crack length, and $\sigma_{\mathrm{f}}$ is the flow stress defined as the average of the yield stress $\left(\sigma_{\mathrm{y}}\right)$ and ultimate stress $\left(\sigma_{\mathrm{u}}\right)$. The LEFM methodology is used where failure involves negligible plastic deformation. The fracture toughness of such materials is represented by the parameter $\mathrm{K}_{\mathrm{Ic}}$ (i.e., plane strain fracture toughness), which characterizes the resistance of the material to unstable crack extension. Under EPFM conditions, an equivalent $\mathrm{K}$ can be determined from the relationship

$$
\mathrm{K}_{\mathrm{Jc}}=\left(\mathrm{E}^{\prime} \mathrm{J}_{\mathrm{Ic}}\right)^{1 / 2}
$$

where $E^{\prime}=E /\left(1-v^{2}\right), E$ is the elastic modulus, and $v$ is the Poisson ratio.

Most published experimental data on neutron embrittlement of austenitic SSs have been obtained on materials irradiated in high-flux fast reactors. ${ }^{11-26}$ In these studies, the embrittlement of the materials has been characterized in terms of tensile properties, Charpy-impact properties, and fracture toughness. Irradiation damage is characterized by either the neutron fluence in neutrons per square centimeter $\left(\mathrm{n} / \mathrm{cm}^{2}\right)$ or the average number of displacements experienced by each atom, i.e., displacements per atom (dpa). ${ }^{*}$ Similar test results under LWR conditions are limited. ${ }^{2,27}$

The effect of neutron exposure (in dpa) on the fracture toughness $\mathrm{J}_{\mathrm{Ic}}$ of austenitic SSs irradiated at $350-450^{\circ} \mathrm{C}\left(662-842^{\circ} \mathrm{F}\right)$ up to $\approx 25 \mathrm{dpa}$ in fast reactors and BWRs is shown in Figs. $1 \mathrm{a}$ and $\mathrm{b}$, respectively. $2,3,11-27$ The fast reactor data show a rapid decrease in fracture toughness at a neutron dose of 1-2 dpa (Fig. 1a); the neutron dose at the onset of the rapid decrease varies with the chemical composition and heat treatment of the steel. The effects of irradiation may be divided into three regimes: little or no loss of toughness below an exposure of $\approx 1 \mathrm{dpa}$, substantial decrease in toughness at exposures of 1-10 dpa, and no further reduction in toughness above a saturation exposure of $10 \mathrm{dpa}$. The degradation in fracture properties saturates at a $\mathrm{J}_{\mathrm{Ic}}$ value of $\approx 30 \mathrm{~kJ} / \mathrm{m}^{2}\left(171 \mathrm{in} .-\mathrm{lb} / \mathrm{in} .{ }^{2}\right)$ [or equivalent

\footnotetext{
* In this study, unless otherwise noted, when neutron dose in dpa was not available, the values of neutron fluence $\left(\mathrm{n} / \mathrm{cm}^{2}\right) \mathrm{were}$ converted to dpa as follows: for LWRs, E $>1 \mathrm{MeV}$ and $10^{22} \mathrm{n} / \mathrm{cm}^{2} \approx 15 \mathrm{dpa}$; and for fast reactors, $\mathrm{E}>0.1 \mathrm{MeV}$ and $10^{22} \mathrm{n} / \mathrm{cm}^{2}$ $\approx 5 \mathrm{dpa}$.
} 
critical stress intensity factor $\mathrm{K}_{\mathrm{Jc}}$ of $75 \mathrm{MPa} \mathrm{m}^{1 / 2}\left(68.2 \mathrm{ksi}\right.$ in. $\left.{ }^{1 / 2}\right)$ ]. Also, the failure mode changes from dimple fracture to channel fracture.

The limited data from BWR irradiations (Fig. 1b) show fracture toughness trends similar to those observed for fast reactor irradiations. Most of the fracture toughness $\mathrm{J}_{\mathrm{Ic}}$ values for austenitic SSs irradiated in BWRs fall within the scatter band of the data obtained on materials irradiated in fast reactors at temperatures higher than $288^{\circ} \mathrm{C}\left(550^{\circ} \mathrm{F}\right) .{ }^{27}$ However, some tests on BWR irradiated materials report $\mathrm{K}_{\mathrm{Ic}}$ values of 45-60 MPa m ${ }^{1 / 2}$ (41-55 $\left.\mathrm{ksi}^{\text {in. }}{ }^{1 / 2}\right)$, corresponding to $\mathrm{J}_{\mathrm{Ic}}$ of $11-20 \mathrm{~kJ} \mathrm{~m}^{2}$.

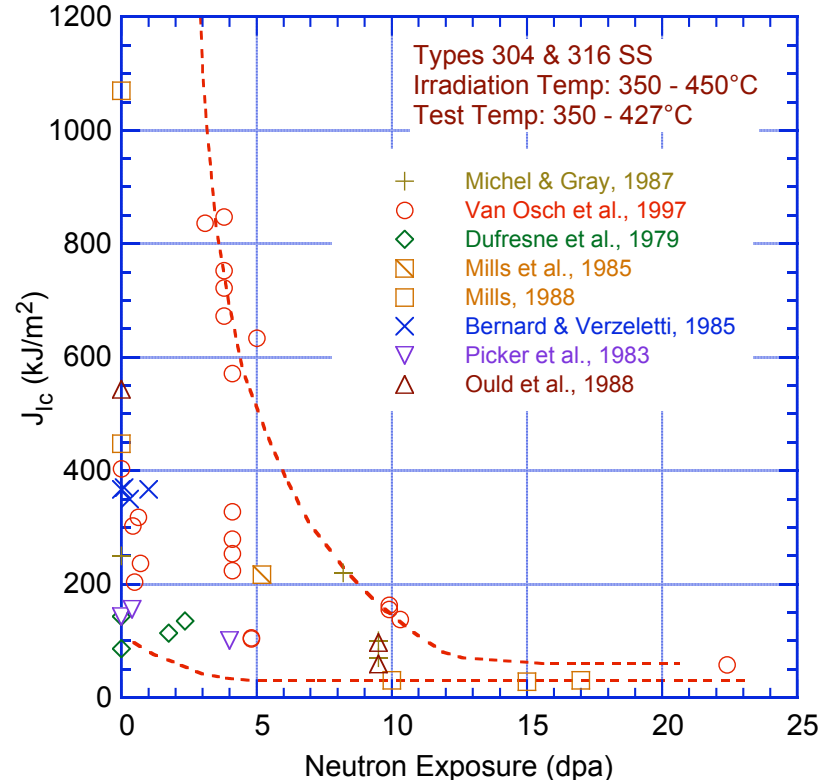

(a)

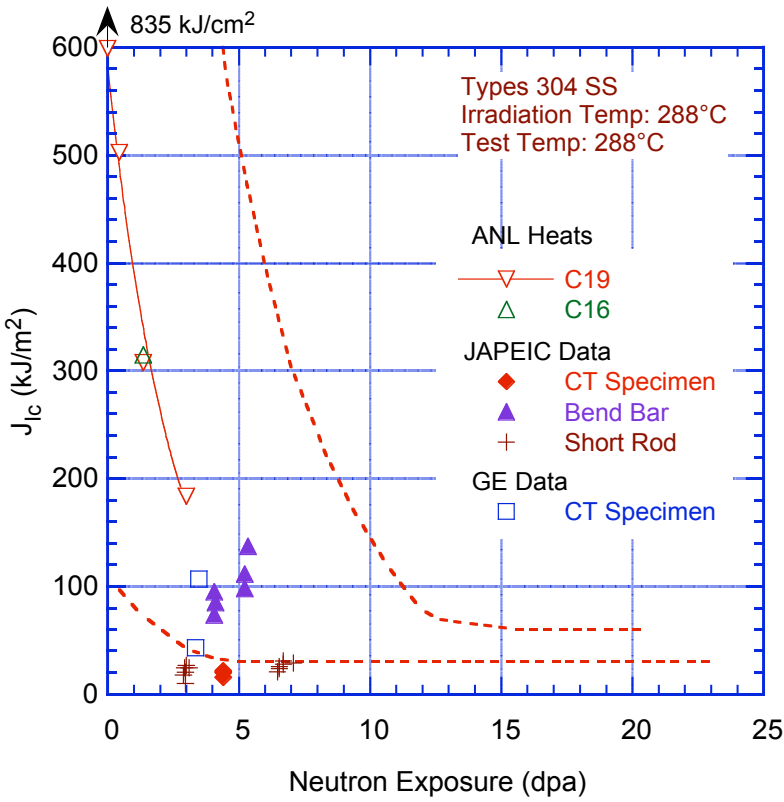

(b)

Figure 1. Fracture toughness $\mathrm{J}_{\mathrm{lc}}$ as a function of neutron exposure for austenitic Types 304 and 316 stainless steels irradiated in (a) fast reactors and (b) BWRs. Dashed lines represent upper and lower bounds for change in $\mathrm{J}_{\mathrm{IC}}$ for austenitic SSs irradiated at $350-450^{\circ} \mathrm{C}$ in fast reactors.

Another issue that has been a concern for reactor core internal components is the possibility of a synergistic interaction between irradiation and thermal embrittlement of cast austenitic SSs and SS weld metals. ${ }^{28-32}$ Although wrought SSs are typically completely austenitic, welded and cast SSs have a duplex microstructure consisting of austenite and ferrite phases. The ferrite phase increases the tensile strength and improves resistance to SCC, but it is susceptible to thermal embrittlement after extended service at reactor operating temperatures. Thermal aging of cast SSs at $250-400^{\circ} \mathrm{C}\left(482-752^{\circ} \mathrm{F}\right)$ leads to precipitation of additional phases in the ferrite (e.g., formation of Cr-rich $\alpha^{\prime}$ phase by spinodal decomposition; nucleation and growth of $\alpha^{\prime}$; precipitation of a Ni- and Si-rich $\mathrm{G}$ phase, $\mathrm{M}_{23} \mathrm{C}_{6}$ carbide, and $\gamma_{2}$ austenite; and additional precipitation and/or growth of existing carbides at the ferrite/austenite phase boundaries). ${ }^{33-36}$ The formation of the Cr-rich $\alpha^{\prime}$ phase by spinodal decomposition of ferrite is the primary mechanism for thermal embrittlement; it strengthens the ferrite phase by increasing strain hardening and the local tensile stress. Thermal aging has little or no effect on the austenite phase. Thus, thermal aging of cast SSs leads to the development of a material with a brittle phase dispersed in a ductile matrix.

Embrittlement of the ferrite phase due to neutron irradiation occurs much faster than for austenitic SSs; at reactor operating temperatures of $288-343^{\circ} \mathrm{C}\left(550-650^{\circ} \mathrm{F}\right)$ a shift in the nil-ductility transition 
( $\triangle \mathrm{NDT})$ temperature of up to $150^{\circ} \mathrm{C}\left(302^{\circ} \mathrm{F}\right)$ has been observed in pressure vessel steels after neutron exposures of $0.07-0.15 \mathrm{dpa}\left(0.5-1.0 \times 10^{20} \mathrm{n} / \mathrm{cm}^{2}\right) .{ }^{37}$ The irradiation temperature is an important factor in establishing the extent of embrittlement of ferritic steels. Although both the thermal aging embrittlement of ferrite and the neutron irradiation embrittlement of ferrite are well characterized, the synergistic effect of thermal aging and neutron irradiation on the embrittlement of SS welds and cast SSs has not been investigated yet.

Neutron irradiation increases the susceptibility of austenitic SSs to IASCC by changing the material microchemistry (e.g., radiation-induced segregation); material microstructure (e.g., radiation hardening); and water chemistry (e.g., radiolysis). ${ }^{1,5,6}$ The factors that influence the IASCC susceptibility of materials include neutron fluence, cold work, material composition, corrosion potential, water purity, temperature, and loading. The effects of neutron fluence on the IASCC of SSs have been investigated for BWR control blade sheaths ${ }^{38-40}$ and in laboratory tests on BWR-irradiated material. ${ }^{5,41-46}$ The results indicate that the extent of intergranular (IG) SCC increases with fluence. The percent IGSCC measured in various irradiated SS specimens is plotted as a function of fast neutron fluence in Fig. 2. Although a threshold fluence level of $5 \times 10^{20} \mathrm{n} / \mathrm{cm}^{2}(\mathrm{E}>1 \mathrm{MeV}) *(\approx 0.75 \mathrm{dpa})$ has been proposed for austenitic SSs in BWR environments, ${ }^{5,47}$ the results in Fig. 2 indicate an increase in IG cracking susceptibility in some commercial-purity SSs at fluence levels of $\approx 2 \times 10^{20} \mathrm{n} / \mathrm{cm}^{2}(\approx 0.3 \mathrm{dpa})$ and in high-purity heats of SSs at even lower fluence levels.

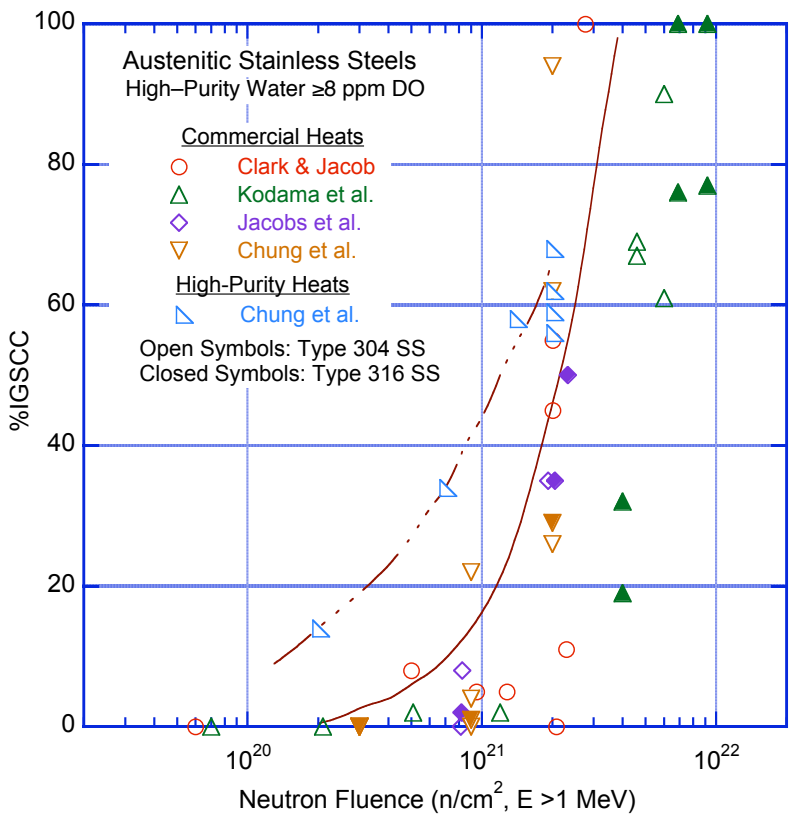

Figure 2.

Susceptibility of irradiated austenitic SSs to IGSCC as a function of fluence in high-DO water. From slow-strain-rate tensile tests

(Refs. 41,43-45).

Constant extension rate tests on Types 304 and 316 SS irradiated to $0.3-4.0 \times 10^{21} \mathrm{n} / \mathrm{cm}^{2}(0.45$ $6.0 \mathrm{dpa}$ ) in a commercial BWR show a beneficial effect of reducing the corrosion potential of the environment. ${ }^{6,48}$ This finding suggests that the threshold fluence for IASCC is higher under low potential conditions such as BWR hydrogen water chemistry (HWC) or PWR primary water chemistry. However, low corrosion potential does not provide immunity to IASCC if the fluence is high enough. For example, IGSCC has been observed in cold-worked, irradiated SS baffle bolts in PWRs.

\footnotetext{
*All references to fluence levels are calculated for $\mathrm{E} \geq 1 \mathrm{MeV}$.
} 
The work at Argonne National Laboratory (ANL) on irradiated SSs sponsored by the Nuclear Regulatory Commission (NRC) is intended to provide a better understanding of the cracking and fracture toughness of BWR core internal components. The effect of neutron irradiation on the fracture toughness and IASCC behavior of austenitic SSs is being evaluated as a function of the fluence level, material composition, and water chemistry. Experimental data are being obtained on fracture toughness, corrosion fatigue, and SCC of Types 304 and 316 SS base metal and weld heat-affected zone (HAZ) as well as cast SSs that were irradiated to fluence levels up to $2.0 \times 10^{21} \mathrm{n} / \mathrm{cm}^{2}(3.0 \mathrm{dpa})$ at $\approx 288^{\circ} \mathrm{C}$. Fracture toughness $\mathrm{J}-\mathrm{R}$ curve tests are being conducted in air and normal water chemistry (NWC) BWR environment at $289^{\circ} \mathrm{C}$, and the crack growth rate (CGR) tests are being conducted in NWC and HWC BWR environments at $\approx 289^{\circ} \mathrm{C}$.

This report presents the following:

- $\quad$ CGR data for Type 316 SS irradiated to $0.3,0.9$, and $2.0 \times 10^{21} \mathrm{n} / \mathrm{cm}^{2}(0.45,1.35$, and $3.0 \mathrm{dpa})$,

- $\quad$ CGR and fracture toughness data for sensitized Type 304 SS and SS weld HAZ materials irradiated to $1.44 \times 10^{21} \mathrm{n} / \mathrm{cm}^{2}(2.16 \mathrm{dpa})$, and

- $\quad$ CGR and fracture toughness data for cast CF-8M SS irradiated to $1.63 \times 10^{21} \mathrm{n} / \mathrm{cm}^{2}(2.46 \mathrm{dpa})$.

The weld HAZ specimens were obtained from a Type 304L submerged arc (SA) weld and a Type 304 SS shielded metal arc (SMA) weld. 
This page is intentionally left blank. 


\section{Experimental}

\subsection{Alloys and Specimen Preparation}

Crack growth rate and fracture toughness J-R curve tests have been conducted on 1/4-T compact tension (CT) specimens of irradiated austenitic SSs in simulated BWR environments at $289^{\circ} \mathrm{C}$. A standard CT specimen geometry (Fig. 3) was used in the present study. Tests have been completed on Types 304L, 304, 316L, and 316 SS (Heats C3, C19, C16, and C21, respectively), sensitized Type 304 SS (Heat 10285), HAZ of SA and SMA weld, and thermally aged cast CF-8M SS (Heat 75). The compositions of the various materials that are being investigated in the ANL study are presented in Table 1.

All irradiations were carried out in the Halden heavy boiling water reactor in a helium environment. The CT specimens from Heats C3, C16, C19, and C21 were irradiated in the reactor from April 1992 to November 1999. Six Type 304 SS capsules, each containing four CT specimens, were irradiated to fluence levels of $0.3,0.9$, and $2.0 \times 10^{21} \mathrm{n} / \mathrm{cm}^{2}(0.45,1.35$, and $3.0 \mathrm{dpa})$ at $288 \pm 2{ }^{\circ} \mathrm{C}$. Several spacers made of Type 304 SS wires were used to maintain a fixed gap between the specimens and the inner surface of the capsule during irradiation. To allow a uniform irradiation temperature, the gap was filled with helium. The specimens irradiated to $0.45,1.35$, and 3.0 dpa were discharged from the reactor in October 1992, November 1996, and November 1999, respectively.

A similar dry helium-filled capsule design was used for irradiating the specimens from sensitized SS, weld HAZ material, and cast SS. The neutron dose was monitored by Al/1\% Co wire (for thermal neutrons) and by $\mathrm{Fe}$ and $\mathrm{Ni}$ wires (for fast neutrons) attached to the external surface of the irradiation capsules. Also, each irradiation capsule contained two sets of melting alloy temperature monitors (MATMs) to estimate the specimen temperature. The specimens irradiated to $0.5 \times 10^{21} \mathrm{n} / \mathrm{cm}^{2}(0.75 \mathrm{dpa})$ were discharged from the reactor in September 2002, and those irradiated to $1.44 \times 10^{21} \mathrm{n} / \mathrm{cm}^{2}$ (2.16 dpa) or $1.63 \times 10^{21} \mathrm{n} / \mathrm{cm}^{2}(2.46 \mathrm{dpa})$ were discharged in October 2004. The MATM results indicate that the specimen temperature was greater than $290^{\circ} \mathrm{C}$ and less than $305^{\circ} \mathrm{C}$; i.e., irradiation temperature $\approx 297^{\circ} \mathrm{C}$.

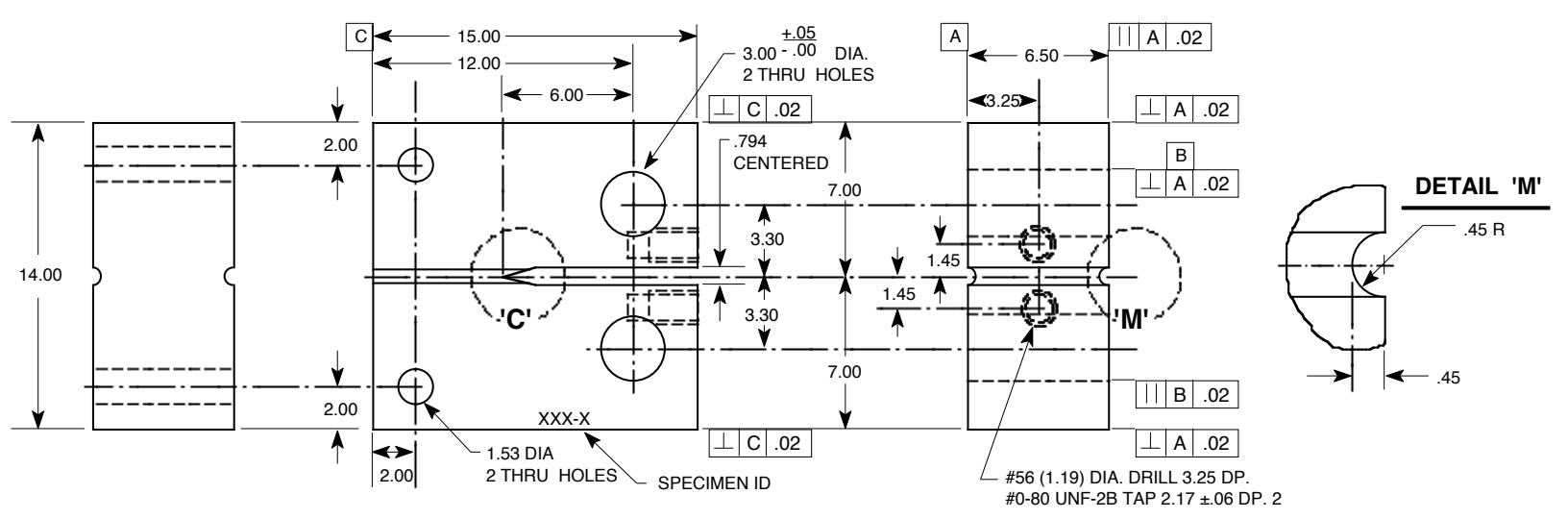

Figure 3. Configuration of compact-tension specimen for this study (dimensions in $\mathrm{mm}$ ).

The SA weld was obtained from the H5 weld of the core shroud from the Grand Gulf (GG) reactor. The top and bottom shroud shells for the GG H5 weld were fabricated from SA 240 Type 304L hot-rolled plate and welded by the SA method with ER308L filler metal using a double-V joint design. The SMA weld was prepared in the laboratory by welding two $70 \times 178 \mathrm{~mm}(2.75 \times 7.0 \mathrm{in}$.) pieces of 30 -mm thick 
Table 1. Composition (wt.\%) of austenitic stainless steels being investigated.

\begin{tabular}{|c|c|c|c|c|c|c|c|c|c|c|c|c|}
\hline $\begin{array}{l}\text { Steel } \\
\text { Type }\end{array}$ & Heat ID & Analysis & $\mathrm{Ni}$ & $\mathrm{Si}$ & $\mathrm{P}$ & $\mathrm{S}$ & $\mathrm{Mn}$ & $\mathrm{C}$ & $\mathrm{N}$ & $\mathrm{Cr}$ & Mo & $\mathrm{O}$ \\
\hline \multirow[t]{2}{*}{$304 \mathrm{~L}$} & $\mathrm{C} 3$ & Vendor & 8.91 & 0.46 & 0.019 & 0.004 & 1.81 & 0.016 & 0.083 & 18.55 & - & - \\
\hline & & ANL & 9.10 & 0.45 & 0.020 & 0.003 & 1.86 & 0.024 & 0.074 & 18.93 & 0.12 & 0.014 \\
\hline \multirow[t]{2}{*}{304} & $\mathrm{C} 19$ & Vendor & 8.08 & 0.45 & 0.031 & 0.003 & 0.99 & 0.060 & 0.070 & 18.21 & - & - \\
\hline & & ANL & 8.13 & 0.51 & 0.028 & 0.008 & 1.00 & 0.060 & 0.068 & 18.05 & 0.09 & 0.020 \\
\hline \multirow[t]{2}{*}{$316 \mathrm{~L}$} & C16 & Vendor & 12.90 & 0.38 & 0.014 & 0.002 & 1.66 & 0.020 & 0.011 & 16.92 & - & - \\
\hline & & ANL & 12.32 & 0.42 & 0.026 & 0.003 & 1.65 & 0.029 & 0.011 & 16.91 & 2.18 & 0.016 \\
\hline \multirow[t]{2}{*}{316} & $\mathrm{C} 21$ & Vendor & 10.24 & 0.51 & 0.034 & 0.001 & 1.19 & 0.060 & 0.020 & 16.28 & 2.08 & - \\
\hline & & ANL & 10.45 & 0.61 & 0.035 & 0.002 & 1.23 & 0.060 & 0.016 & 16.27 & 2.10 & 0.014 \\
\hline \multirow[t]{2}{*}{304} & 10285 & Vendor & 8.40 & 0.51 & 0.032 & 0.006 & 1.64 & 0.058 & - & 18.25 & 0.41 & - \\
\hline & & ANL & 8.45 & 0.60 & 0.015 & 0.007 & 1.90 & 0.070 & 0.084 & 18.56 & 0.51 & 0.013 \\
\hline \multirow[t]{2}{*}{$304 \mathrm{~L}$} & GG Top Shell & ANL & 9.05 & 0.53 & 0.027 & 0.016 & 1.84 & 0.013 & 0.064 & 18.23 & 0.44 & 0.010 \\
\hline & GG Bottom Shell & ANL & 8.95 & 0.55 & 0.023 & 0.008 & 1.80 & 0.015 & 0.067 & 18.62 & 0.31 & 0.014 \\
\hline CF-8M & 75 & ANL & 9.12 & 0.67 & 0.022 & 0.012 & 0.53 & 0.065 & 0.052 & 20.86 & 2.58 & - \\
\hline
\end{tabular}

(1.18-in. thick) plate of Type $304 \mathrm{SS}$ (Heat 10285). The weld had a single-V joint design and was produced by 31 weld passes using E308 filler metal. Passes 1-5 were produced with 3.2-mm (0.125-in.) filler metal rod and $178-\mathrm{mm} / \mathrm{min}(7-\mathrm{ipm})$ travel speed, and passes $6-31$ were produced with $4.0-\mathrm{mm}$ (0.156-in.) filler metal rod and 216- $\mathrm{mm} / \mathrm{min}(8.5$-ipm) travel speed. Between passes the laboratory weld surfaces were cleaned by wire brush and grinding and were rinsed with de-mineralized water or alcohol. The corresponding details of the GG weld procedure are not known to the authors.

There are two potential differences between the GG SA weld HAZ and laboratory-prepared SMA weld HAZ: microstructure and residual strain. The HAZ of high-C austenitic SS welds typically consists of a sensitized microstructure. The low-C grades of SSs are considered to be resistant to weld sensitization. A transmission electron microscopy study of the GG Type 304L weld HAZ in the core shroud vertical weld revealed a few, very small $\mathrm{Cr}$-rich precipitates at the grain boundaries about 1 and $3 \mathrm{~mm}$ (0.04 and 0.12 in.) from the fusion line; however, most boundaries showed no precipitates. ${ }^{49}$ Thus, only the laboratory-prepared weld HAZ is likely to have a sensitized microstructure. The residual strain in various SS weld HAZs has been measured by the electron back-scattered pattern technique. ${ }^{49-52}$ The results indicate that the peak strains typically extend up to $5 \mathrm{~mm}$ from the fusion line and range from 8 to $20 \%$. Residual strains up to $10 \%$ have been measured in the GG Type 304L weld HAZ of core shroud vertical weld. ${ }^{49}$ Because the heat input per pass for SA welds is typically higher than that for SMA welds of comparable geometry, the HAZ associated with an SA weld is wider than that associated with an SMA weld. However, because the total number of passes is less in an SA weld than an SMA weld, residual strains associated with SA welds are smaller.

The specimens were machined from $9.5-\mathrm{mm}(0.37 \mathrm{in}$.) thick slices of the weld; some slices were thermally treated for $24 \mathrm{~h}$ at $500^{\circ} \mathrm{C}$ to simulate low-temperature sensitization. For all specimens, the machined notch was located in the HAZ of the weld. Each slice was etched, and the specimen orientation and notch location relative to the weld were clearly identified. In all cases, the machine notch was located $\approx 1 \mathrm{~mm}(0.04 \mathrm{in}$.) from the fusion zone in a region where the fusion zone was relatively straight.

Metallographic examination of weld HAZ materials showed that the base metal of Heat 10285 of Type 304 SS and the GG Type 304L core shroud shells contain stringers of ferrite (Fig. 4). Heat 10285 appears to have the most ferrite and the GG bottom shell, the least. The grain sizes for the GG top and bottom shell materials are comparable and are larger than those for Heat 10285; for example, the grain size in the HAZ region of the GG shell is $\approx 110 \mu \mathrm{m}$, and that of Heat 10285 is $\approx 80 \mu \mathrm{m}$. In all welds, the fusion line extends into the base metal along the ferrite stringers (Fig. 5). In other words, the ferrite stringers intersecting the fusion line appear to have melted and re-solidified during the welding process. 


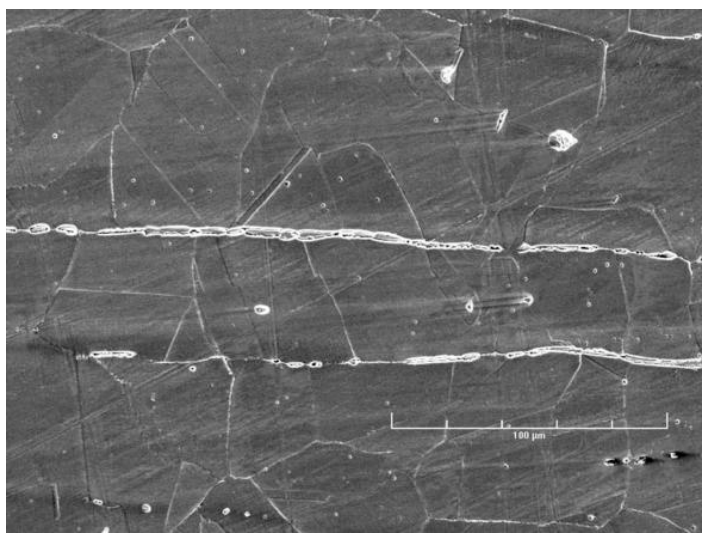

(a)

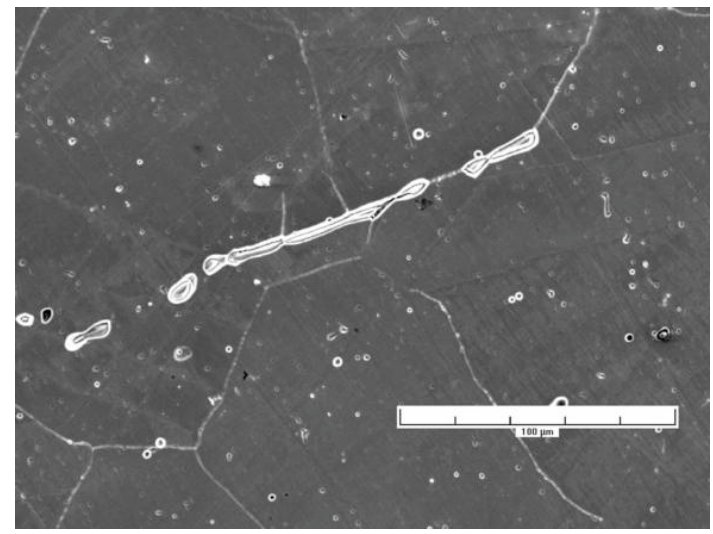

(b)

Figure 4. Micrographs of the structure of (a) Heat 10285 of Type 304 SS and (b) Type 304L from the top shell of the H5 weld of the GG core shroud.

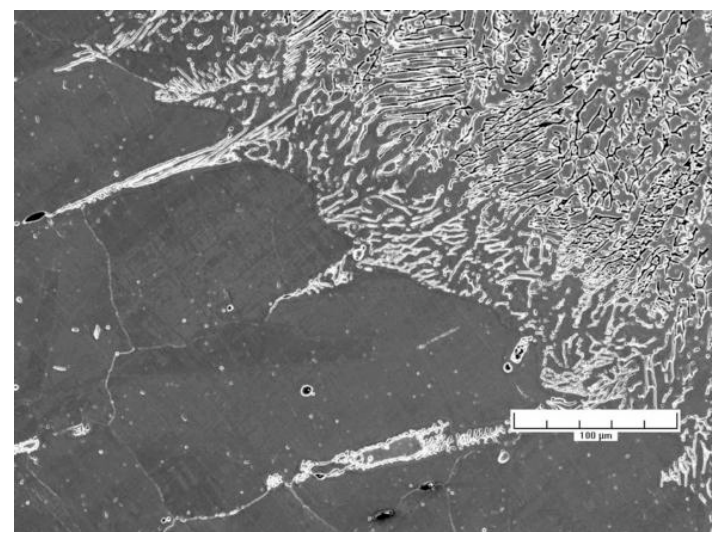

Figure 5.

Micrographs of the interface between the weld metal and top shell of the H5 weld of the GG core shroud.

The cast CF-8M SS was obtained from a static cast plate, $\approx 610 \times 610 \times 76 \mathrm{~mm}(24 \times 24 \times 3 \mathrm{in}$.). The cast SS material has a duplex ferrite-austenite structure consisting of lacy ferrite morphology. Figure 6 shows a photograph of the interlaced network of ferrite islands. The ferrite content, measured by a ferrite scope, was $\approx 28 \%$. Prior to irradiation, the cast SS material was aged for $10,000 \mathrm{~h}$ at $400^{\circ} \mathrm{C}$ $\left(752^{\circ} \mathrm{F}\right)$, and Heat 10285 of Type $304 \mathrm{SS}$ was sensitized for $10.5 \mathrm{~h}$ at $600^{\circ} \mathrm{C}\left(1112^{\circ} \mathrm{F}\right)$.

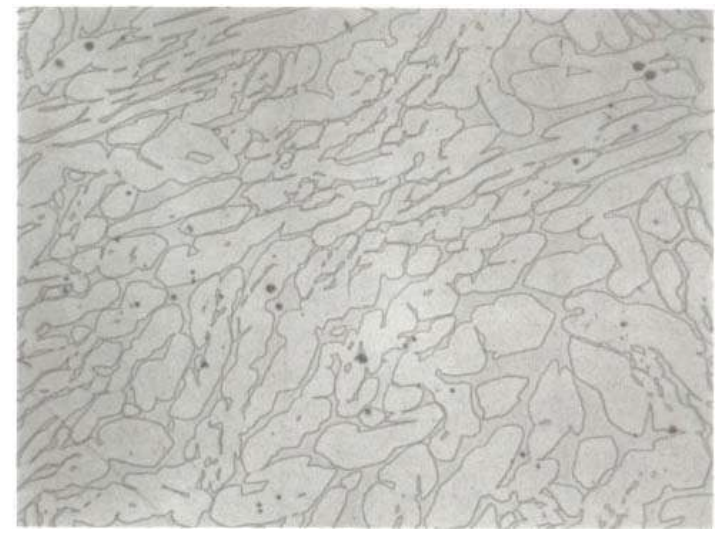

Figure 6.

Ferrite morphology for the CF-8M cast SS.

Table 2 gives the tensile yield and ultimate stress, determined from slow-strain-rate-tensile tests in high-dissolved oxygen (DO) water, for Types 304L, 304, 316L, and 316 SS (Heats C3, C19, C16, and 
C21, respectively), irradiated to the three fluence levels and in the nonirradiated condition. ${ }^{53}$ For the few materials that were tested in air and water environments, the experimental tensile stress was 10-20\% higher in air than in water. Table 3 lists the tensile properties of nonirradiated Type 304L SS from the GG core shroud shell, Heat 10285 of Type 304 SS in the mill-annealed condition and after sensitization at $600^{\circ} \mathrm{C}$ for $10.5 \mathrm{~h}, 54$ and the thermally aged cast CF-8M SS. ${ }^{28}$ For these steels, the tensile properties of the irradiated materials have not been measured and were therefore estimated. The ultimate stresses for the irradiated steels were estimated from the data in Ref. 53, and the yield stress was estimated from the correlation developed by Odette and Lucas. ${ }^{55}$ The increase in yield stress (MPa) is expressed in terms of the fluence (dpa) by the relationship

$$
\Delta \sigma_{\mathrm{y}}=670[1-\exp (-\mathrm{dpa} / 2)]^{0.5} .
$$

The estimated tensile yield and ultimate stresses for the irradiated SSs are given in Table 3. For Heat 10285 and the GG core shroud, the tensile properties of the sensitized material were used to determine the "K/size criterion" (discussed in Section 2.3.1) for nonirradiated and irradiated HAZ specimens, both in the as-welded and as-welded plus thermally-treated conditions.

Table 2. Tensile properties ${ }^{\mathrm{a}}$ at $289^{\circ} \mathrm{C}$ of austenitic stainless steels from Halden Phase I irradiations.

\begin{tabular}{|c|c|c|c|c|c|c|c|c|}
\hline \multirow[b]{3}{*}{$\begin{array}{c}\text { Steel Type } \\
\text { (Heat) }\end{array}$} & & & \multicolumn{6}{|c|}{ Fluence $(\mathrm{E}>1 \mathrm{MeV})$} \\
\hline & \multicolumn{2}{|c|}{ Nonirradiated } & \multicolumn{2}{|c|}{$0.3 \times 10^{21} \mathrm{n} / \mathrm{cm}^{2}(0.45 \mathrm{dpa})$} & \multicolumn{2}{|c|}{$0.9 \times 10^{21} \mathrm{n} / \mathrm{cm}^{2}(1.35 \mathrm{dpa})$} & \multicolumn{2}{|c|}{$2.0 \times 10^{21} \mathrm{n} / \mathrm{cm}^{2}(3.00 \mathrm{dpa})$} \\
\hline & $\begin{array}{l}\text { Yield } \\
\text { (MPa) }\end{array}$ & $\begin{array}{c}\text { Ultimate } \\
\text { (MPa) }\end{array}$ & $\begin{array}{l}\text { Yield } \\
\text { (MPa) }\end{array}$ & $\begin{array}{l}\text { Ultimate } \\
\text { (MPa) }\end{array}$ & $\begin{array}{l}\text { Yield } \\
\text { (MPa) }\end{array}$ & $\begin{array}{l}\text { Ultimate } \\
\text { (MPa) }\end{array}$ & $\begin{array}{l}\text { Yield } \\
(\mathrm{MPa})\end{array}$ & $\begin{array}{l}\text { Ultimate } \\
(\mathrm{MPa})\end{array}$ \\
\hline 304L SS (C3) & $(154)$ & (433) & 338 & 491 & 632 & 668 & 796 & 826 \\
\hline 304 SS (C19) & 178 & 501 & 554 & 682 & 750 & 769 & 787 & 801 \\
\hline 316L SS (C16) & (189) & $(483)$ & 370 & 527 & 562 & 618 & 766 & 803 \\
\hline $316 \mathrm{SS}(\mathrm{C} 21)$ & 277 & 455 & 480 & 620 & 643 & 716 & 893 & 924 \\
\hline
\end{tabular}

aEstimated values within parentheses.

Table 3. Tensile properties ${ }^{\mathrm{a}}$ at $289^{\circ} \mathrm{C}$ of austenitic stainless steels from Halden Phase II irradiations.

\begin{tabular}{|c|c|c|c|c|c|c|c|}
\hline $\begin{array}{l}\text { Steel Type } \\
\text { (Heat) }\end{array}$ & $\begin{array}{c}\text { Material } \\
\text { Condition }\end{array}$ & $\begin{array}{l}\text { Yield } \\
\text { (MPa) }\end{array}$ & $\begin{array}{l}\text { Ultimate } \\
\text { (MPa) }\end{array}$ & $\begin{array}{l}\text { Yield } \\
\text { (MPa) }\end{array}$ & $\begin{array}{l}\text { Ultimate } \\
\text { (MPa) }\end{array}$ & $\begin{array}{l}\text { Yield } \\
(\mathrm{MPa}) \\
\end{array}$ & $\begin{array}{l}\text { Ultimate } \\
(\mathrm{MPa})\end{array}$ \\
\hline & & \multicolumn{2}{|c|}{ Nonirradiated } & \multicolumn{2}{|c|}{$0.5 \times 10^{21} \mathrm{n} / \mathrm{cm}^{2}(0.75 \mathrm{dpa})$} & \multicolumn{2}{|c|}{$1.44 \times 10^{21} \mathrm{n} / \mathrm{cm}^{2}(2.16 \mathrm{dpa})$} \\
\hline \multirow[t]{2}{*}{304 SS (10285) } & Mill annealed & 196 & 508 & - & - & & \\
\hline & $\mathrm{MA}+10.5 \mathrm{~h}$ at $600^{\circ} \mathrm{C}$ & 156 & 501 & (531) & (680) & $(670)$ & $(780)$ \\
\hline \multirow[t]{3}{*}{ 304L SS GG Core Shroud } & Mill annealed & 158 & 411 & - & - & & \\
\hline & $\mathrm{MA}+10.5 \mathrm{~h}$ at $600^{\circ} \mathrm{C}$ & 159 & 425 & (533) & $(610)$ & $(702)$ & $(720)$ \\
\hline & & \multicolumn{2}{|c|}{ Nonirradiated } & & & \multicolumn{2}{|c|}{$1.63 \times 10^{21} \mathrm{n} / \mathrm{cm}^{2}(2.46 \mathrm{dpa})$} \\
\hline CF-8M (75) & As-cast $+10,000 \mathrm{~h}$ at $400^{\circ} \mathrm{C}$ & 207 & 612 & & & $(740)$ & $(780)$ \\
\hline
\end{tabular}

aEstimated values within parentheses.

\subsection{Test Facility}

The facility for conducting crack growth and fracture toughness tests on irradiated austenitic SSs is designed for in-cell testing, with the test frame, furnace, and other required equipment mounted on top of a portable wheeled cart that can be easily rolled into the cell. A 1-liter SS autoclave is installed inside the furnace for conducting tests in simulated BWR environments. The furnace is mounted on a pneumatic cylinder and can be raised to enclose the autoclave with the load cage and the specimen during the test. Water is circulated through a port in the autoclave cover plate that serves both as inlet and outlet. The hydraulic actuator is mounted on top of the test frame, with the load train components suspended beneath it. The 22-kN (5-kip) load cell is at the top of the pull rod. An Instron Model 8500+ Dynamic Materials 
Testing System is used to load the specimen. A photograph of the test facility inside the hot cell is shown in Fig. 7.

The 1/4-T CT specimen is mounted in the clevises with 17-4 PH SS pins. Crack extensions are monitored by the reversing direct-current (DC) potential difference method. The specimen and clevises are kept electrically insulated from the load train by using oxidized Zircaloy pins and mica washers to connect the clevises to the rest of the load train. The Zircaloy pins were oxidized at $500^{\circ} \mathrm{C}$ for $24 \mathrm{~h}$ and air-cooled. Platinum wires are used for the current and potential leads. The current leads are attached to SS split pins that are inserted into the holes at the top and bottom of the specimen. The potential leads are attached by screwing short SS pins into threaded holes on the front face of the specimen and attaching the platinum wires with in-line SS crimps.

The recirculating water system consists of a storage tank, high pressure pump, regenerative heat exchanger, autoclave preheater, test autoclave, electrochemical potential (ECP) cell preheater, ECP cell, regenerative heat exchanger, Mity Mite $^{\mathrm{TM}}$ back-pressure regulator, an ion-exchange cartridge, a 0.2 micron filter, a demineralizer resin bed, another 0.2 micron filter, and return line to the tank. A schematic diagram of the recirculating water system is shown in Fig. 8.

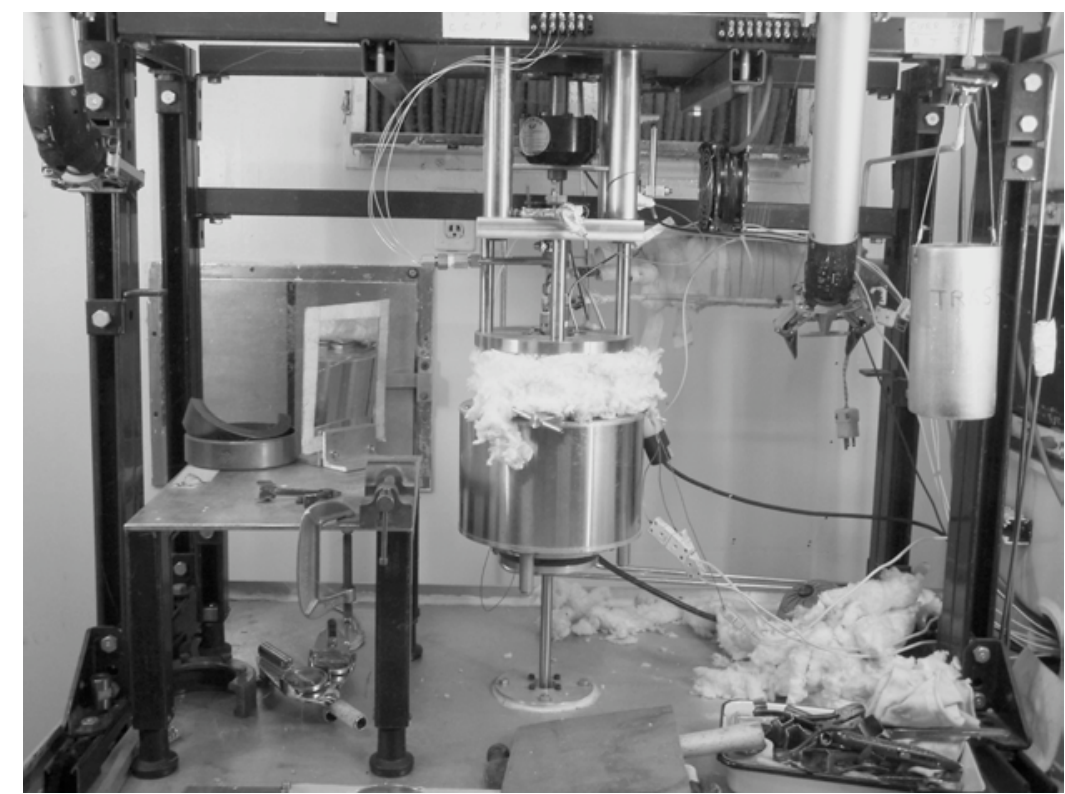

Figure 7. Photograph of the test facility inside the hot cell.

The simulated BWR environments consist of high-purity deionized water that either contains 250$500 \mathrm{ppb}$ DO (corresponding to NWC BWR water), or $<30 \mathrm{ppb}$ DO (corresponding to HWC BWR water). The resulting ECPs for SS are in the range of 160 to $240 \mathrm{mV}$ versus a standard hydrogen electrode (SHE) for NWC and -200 to $-500 \mathrm{mV}$ (vs. SHE) for HWC. The feedwater is stored in a 135-L SS tank manufactured by Filpaco Industries. The tank is designed for vacuums and over-pressures up to $414 \mathrm{kPa}$ (60 psig). The deionized water is prepared by passing purified water through a set of filters that comprise a carbon filter, an Organex-Q filter, two ion exchangers, and a $0.2-\mathrm{mm}(8-\mathrm{mil})$ capsule filter. The DO level in water is established by maintaining a cover gas of nitrogen plus $1 \%$ oxygen above the supply tank and initially bubbling the gas mixture through the deionized water. The ECP of a Pt electrode and an SS sample located at the exit of the autoclave was monitored continuously during the test, and water samples were taken periodically to measure $\mathrm{pH}$, resistivity, and $\mathrm{DO}$ concentration. The DO level was measured in the in-cell facility by the colorimetric technique using CHEMets sampling ampoules. 


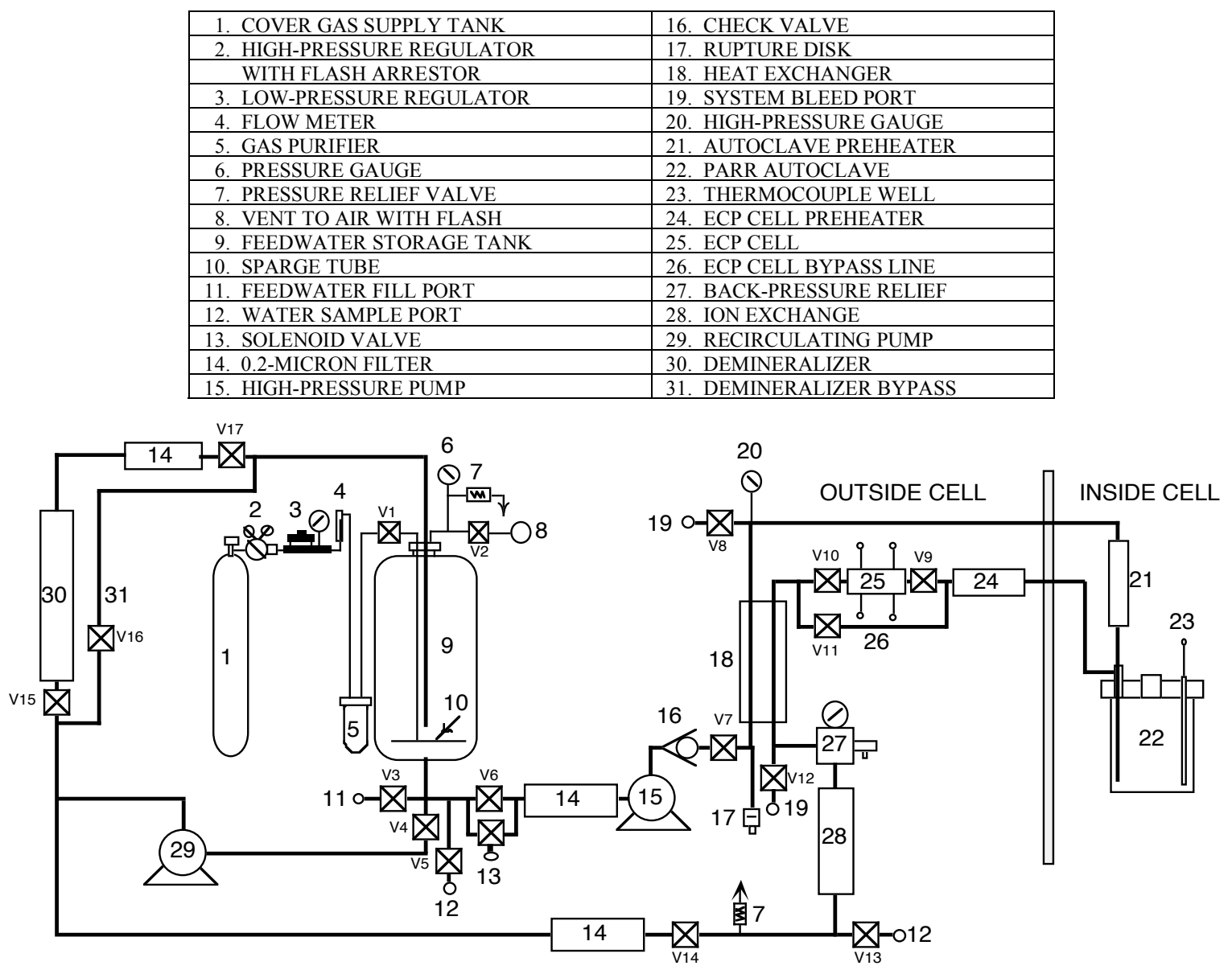

Figure 8. Schematic diagram of the water system.

All tests in simulated BWR environment were started in high-purity water that contained 250$500 \mathrm{ppb}$ DO. After data were obtained for high-DO water, the DO level in the feedwater was decreased to $<30 \mathrm{ppb}$ by sparging it with a gas mixture of $\mathrm{N}_{2}+5 \% \mathrm{H}_{2}$. Because of the very low water flow rates, it took several days for the environmental conditions to stabilize for the in-cell tests. In general, the changes in ECP were slower in the SS sample than in the Pt electrode.

The autoclave, but without the water, was also used as the test chamber for conducting CGR and fracture toughness tests in air. The specimen temperature was monitored with a thermocouple located near the specimen and by measuring the temperatures of the top and bottom clevis.

\subsection{Test Procedure}

\subsubsection{Crack Growth Rate Tests}

The CGR tests were performed in accordance with American Society for Testing and Materials (ASTM) E-647, "Standard Test Method for Measurement of Fatigue Crack Growth Rates," and ASTM E-1681, "Standard Test Method for Determining a Threshold Stress Intensity Factor for EnvironmentAssisted Cracking of Metallic Materials under Constant Load." The tests were conducted in the loadcontrol mode using a triangular or sawtooth waveform with load ratio $\mathrm{R}$ of 0.2-0.7. All specimens were fatigue precracked in the test environment at $\mathrm{R}=0.2-0.3$, frequency of $1-5 \mathrm{~Hz}$, and maximum stress intensity factor $\left(\mathrm{K}_{\max }\right)$ of $13-16 \mathrm{MPa} \mathrm{m}^{1 / 2}$. After $0.3-0.5 \mathrm{~mm}$ crack extension, a prescribed loading 
sequence was followed to facilitate the transition of a transgranular (TG) fatigue crack to an IG stress corrosion crack. To achieve this transition, $\mathrm{R}$ was increased incrementally to 0.7 , and the loading waveform changed to a slow/fast sawtooth with rise times of 30-1000 s. The SCC growth rates were measured under constant load with or without periodic partial unloading to $\mathrm{R}=0.7$ every 1 or $2 \mathrm{~h}$; the unload/reload period was $24 \mathrm{~s}$. During individual test periods, $\mathrm{K}_{\max }$ was maintained approximately constant by periodic load shedding (less than $2 \%$ decrease in load at any given time); $\mathrm{K}_{\max }$ at the end of the test period is reported in the results.

In the present study, crack length "a" was calculated from the following correlation, which was developed from the best fit of the experimental data for normalized crack length and normalized DC potential:

$$
\frac{\mathrm{a}}{\mathrm{W}}=\left[0.28887\left(\frac{\mathrm{U}}{\mathrm{U}_{0}}-0.5\right)\right]^{0.34775}
$$

where $\mathrm{W}$ is the specimen width, and $\mathrm{U}$ and $\mathrm{U}_{0}$ are the current and initial potentials, respectively. Equation 4 is comparable to the ASTM E 1737 correlation for a CT specimen with current inputs at the $\mathrm{W} / 4$ position and DC potential lead connections at the W/3 position. Also, the stress intensity factor range $\Delta \mathrm{K}$ was calculated from the correlations for a $\mathrm{CT}$ specimen as follows:

$$
\begin{aligned}
& \Delta \mathrm{K}=\frac{\Delta \mathrm{P} \quad 1 / 2}{\left(\mathrm{BB}_{\mathrm{N}} \mathrm{W}\right)} \frac{\left(2+\frac{\mathrm{a}}{\mathrm{W}}\right)}{\left(1-\frac{\mathrm{a}}{\mathrm{W}}\right)^{3 / 2}} \mathrm{f}\left(\frac{\mathrm{a}}{\mathrm{W}}\right), \\
& \Delta \mathrm{P}=\Delta \mathrm{P}_{\max }-\Delta \mathrm{P}_{\min } \quad \text { for } \mathrm{R}>0, \\
& \mathrm{f}\left(\frac{\mathrm{a}}{\mathrm{W}}\right)=0.886+4.64\left(\frac{\mathrm{a}}{\mathrm{W}}\right)-13.32\left(\frac{\mathrm{a}}{\mathrm{W}}\right)^{2}+14.72\left(\frac{\mathrm{a}}{\mathrm{W}}\right)^{3}-5.60\left(\frac{\mathrm{a}}{\mathrm{W}}\right)^{4},
\end{aligned}
$$

where $\mathrm{P}_{\max }$ and $\mathrm{P}_{\min }$ are maximum and minimum applied load, respectively; $\mathrm{B}$ is the specimen thickness; $\mathrm{B}_{\mathrm{N}}$ is the net specimen thickness (or distance between the roots of the side grooves).

In an earlier report, ${ }^{27}$ experimental J-R curve data were obtained at ANL on irradiated Types 304 and 316L SS (Heats C19 and C16, respectively), and K values were calculated using the correlations for a disc-shaped specimen instead of a standard CT specimen. The earlier data have been corrected using Eqs. 5-7; the corrected data are given in Appendix B of this report. The difference between the J-R curves based on the correlations for a disc-shaped specimen and standard CT specimen is minimal.

In the present test facility, the Bal-seal ${ }^{\mathrm{TM}}$ between the pull rod and the autoclave cover plate exerts a frictional load on the pull rod. In earlier tests, the frictional load typically varied in the range of $\pm 22-44 \mathrm{~N}$ $( \pm 5-10 \mathrm{lb})$. However, the pull rod was replaced for the tests being performed on Halden Phase II specimens, and the frictional load on the new pull rod is in the range of $\pm 111-133 \mathrm{~N}( \pm 25-30 \mathrm{lb})$. Therefore, the measured values of $\mathrm{P}_{\max }$ and $\mathrm{P}_{\min }$ are first corrected for the frictional load before calculating the $\Delta \mathrm{K}$ for the various test periods. The applied $\mathrm{K}$ and load ratio for each test period are 
determined by subtracting the frictional load from the measured maximum load and adding it to the measured minimum load. The most significant effect of this correction is on the waveform for the cyclic tests; although the tests were intended to be conducted with either triangular or sawtooth waveforms, the actual loading waveforms for the test specimen are trapezoidal because the load did not change during the initial $40-50 \%$ of the loading or unloading cycles. For example, for a test intended to be conducted at $\mathrm{R}=0.7$ and a sawtooth waveform with 300-s rise time and 12-s return time, the actual loading waveform was trapezoidal with 112-s hold at minimum load, 188-s rise time, 6-s hold at maximum load, and 6-s return time. Because the autoclave, including the Bal-seal in the cover plate, was used as the test chamber for tests in air, the experimental data for the air tests were also corrected for frictional load.

During each test period, the CGR was determined from the slope of the corrected crack length vs. time plots; for cyclic loading, only the rise time was used to determine growth rate. The crack extension during each test period was at least 10 times the resolution of the DC potential drop method (i.e., typically $5 \mu \mathrm{m}$ ). Thus, crack extensions were at least $50 \mu \mathrm{m}$; for test periods with very low CGRs (e.g., less than $1 \times 10^{-11} \mathrm{~m} / \mathrm{s}$ ), smaller crack extensions were used to reduce testing time.

The CGR test results were validated in accordance with the specimen size criteria of ASTM E 1681 and E 647. Fracture mechanics is a correlative technology, i.e., it does not attempt to describe the mechanisms that are occurring at the crack tip. It correlates the behavior of components with that of specimens through the use of the $\mathrm{K}$ parameter. If two cracks have the same $\mathrm{K}$, then they have the same strains and stresses in a region near the crack tip. For this correlation between specimen and component to work, $\mathrm{K}$ has to control the stresses and strains at the crack tip in the process zone. Mathematically it can be shown that this is true if the plastic zone size is "small enough". The $\mathrm{K} /$ size criteria are combined theoretical and empirical results that have been found to ensure the plastic zone is small enough and $\mathrm{K}$ is controlling. The ASTM specifications for specimen $\mathrm{K} /$ size criteria are intended to ensure the applicability and transferability of the cracking behavior of a component or specimen of a given thickness under a specific loading condition to a crack associated with a different geometry, thickness, and loading condition. For constant load tests, ASTM E 1681 requires that

$$
\mathrm{B}_{\text {eff }} \text { and }(\mathrm{W}-\mathrm{a}) \geq 2.5\left(\mathrm{~K} / \sigma_{\mathrm{y}}\right)^{2} \text {, }
$$

and for cyclic loading, ASTM 647 requires that

$$
\mathrm{B}_{\text {eff }} \text { and }(\mathrm{W}-\mathrm{a}) \geq(4 / \pi)\left(\mathrm{K} / \sigma_{\mathrm{y}}\right)^{2} \text {, }
$$

where $\mathrm{K}$ is the applied stress intensity factor, $\sigma_{\mathrm{y}}$ is the yield stress of the material, a is crack length, and the $\mathrm{B}_{\text {eff }}$ is the specimen effective thickness, defined as $\left(\mathrm{B} \mathrm{B}_{\mathrm{N}}\right)^{0.5}$. For high strain-hardening materials, i.e., $\left(\sigma_{\mathrm{u}} / \sigma_{\mathrm{y}}\right) \geq 1.3$, both criteria allow the use of the flow stress defined as $\sigma_{\mathrm{f}}=\left(\sigma_{\mathrm{u}}+\sigma_{\mathrm{y}}\right) / 2$ rather than the yield stress.

However, the database for defining the $\mathrm{K} /$ size criteria for irradiated materials is inadequate. The $\mathrm{K} /$ size criteria were developed for materials that show work hardening and, therefore, may not be applicable for materials irradiated to fluence levels where, on a local level, they do not strain harden. This lack of strain hardening, termed "strain softening," is most dramatic when dislocation channeling occurs but may also occur at lower fluences. For moderate to highly irradiated material, Andresen ${ }^{56}$ has suggested an effective yield stress, defined as the average of the nonirradiated and irradiated yield stresses $\left[\sigma_{\text {eff }}=\left(\sigma_{\text {yirr }}+\sigma_{\text {ynonirr }}\right) / 2\right]$; this discounts the irradiation-induced increase in yield stress by a factor of 2 . 
Jenssen et al. 57 obtained crack growth data in simulated BWR environment on Type 304L SS irradiated to $\approx 13 \mathrm{dpa}$ and investigated the specimen $\mathrm{K} /$ size criterion for CGR testing of irradiated austenitic SSs. They performed a finite element study that indicated that if the strain softening found in highly irradiated materials is taken into account, there is a significant amount of plastic deformation in the plane of the growing crack if the $\mathrm{K} /$ size criterion is defined as $\sigma_{\mathrm{eff}}=\left(\sigma_{\mathrm{yirr}}+\sigma_{\mathrm{ynonirr}}\right) / 2$. The authors argue that as a result of an increased tendency for "highly irradiated material" to deform by dislocation channeling, a $\mathrm{K} /$ size criterion based on the sum of irradiated and nonirradiated yield stress divided by 3 [i.e., $\sigma_{\text {eff }}=\left(\sigma_{\text {yirr }}+\sigma_{\text {ynonirr }}\right) / 3$ ] fits the crack growth behavior better. ${ }^{57}$

In the present study, because the ultimate-to-yield stress ratio was generally less than 1.3 , the effective yield stress was used to determine the allowed $\mathrm{K}_{\max }$ for the irradiated specimens. The only exception was austenitic SSs irradiated to $\approx 0.45 \mathrm{dpa}$, where effective flow stress was used to determine allowed $\mathrm{K}_{\max }$ for this specimen. Also, because the materials that have been investigated in the present study were irradiated only up to $\approx 3 \mathrm{dpa}$, the effective yield stress was defined as $\left(\sigma_{\text {yirr }}+\sigma_{\text {ynonirr }}\right) / 2$.

Under cyclic loading, the CGR $(\mathrm{m} / \mathrm{s})$ can be expressed as the superposition of the rate in air (i.e., mechanical fatigue) and the rates due to corrosion fatigue and SCC, given as

$$
\dot{\mathrm{a}}_{\mathrm{env}}=\dot{\mathrm{a}}_{\mathrm{air}}+\dot{\mathrm{a}}_{\mathrm{cf}}+\dot{\mathrm{a}}_{\mathrm{scc}} .
$$

The CGRs in air, $\dot{\mathrm{a}}_{\text {air }}(\mathrm{m} / \mathrm{s})$, were determined from the correlations developed by James and Jones: ${ }^{58}$

$$
\dot{\mathrm{a}}_{\text {air }}=\mathrm{C}_{\mathrm{SS}} \mathrm{S}(\mathrm{R}) \Delta \mathrm{K}^{3.3} / \mathrm{t}_{\mathrm{r}}
$$

where $R$ is the load ratio $\left(K_{\min } / K_{\max }\right), \Delta K$ is $K_{\max }-K_{\min }$ in $M P a m^{1 / 2}, t_{r}$ is the rise time (s) of the loading waveform, and the function $\mathrm{S}(\mathrm{R})$ is expressed in terms of the load ratio $\mathrm{R}$ as follows:

$$
\begin{array}{ll}
\mathrm{S}(\mathrm{R})=1.0 & \mathrm{R}<0 \\
\mathrm{~S}(\mathrm{R})=1.0+1.8 \mathrm{R} & 0<\mathrm{R}<0.79 \\
\mathrm{~S}(\mathrm{R})=-43.35+57.97 \mathrm{R} & 0.79<\mathrm{R}<1.0 .
\end{array}
$$

Function $\mathrm{C}_{\mathrm{SS}}$ is given by a third-order polynomial of temperature $\mathrm{T}\left({ }^{\circ} \mathrm{C}\right)$, expressed as

$$
\mathrm{C}_{\mathrm{SS}}=1.9142 \times 10^{-12}+6.7911 \times 10^{-15} \mathrm{~T}-1.6638 \times 10^{-17} \mathrm{~T}^{2}+3.9616 \times 10^{-20} \mathrm{~T}^{3} .
$$

Environmental effects on fatigue crack growth of nonirradiated austenitic SSs have been investigated by Shack and Kassner. ${ }^{59}$ In the absence of any significant contribution of SCC to growth rate, the CGRs in water with $\approx 0.3 \mathrm{ppm}$ DO are best represented by the expression

$$
\dot{\mathrm{a}}_{\text {env }}=\dot{\mathrm{a}}_{\text {air }}+4.5 \times 10^{-5}\left(\dot{\mathrm{a}}_{\text {air }}\right)^{0.5}
$$

and in water with $\approx 8 \mathrm{ppm}$ DO by the expression,

$$
\dot{\mathrm{a}}_{\text {env }}=\dot{\mathrm{a}}_{\text {air }}+1.5 \times 10^{-4}\left(\dot{\mathrm{a}}_{\text {air }}\right)^{0.5} \text {. }
$$

The CGR $(\mathrm{m} / \mathrm{s})$ under SCC conditions is represented by the correlation given in the U.S. NRC report NUREG-0313, Rev. 2:60 


$$
\dot{\mathrm{a}}_{\mathrm{SCC}}=\mathrm{A}(\mathrm{K})^{2.161}
$$

where $\mathrm{K}$ is the stress intensity factor $\left(\mathrm{MPa} \mathrm{m}^{1 / 2}\right)$, and the magnitude of the constant $\mathrm{A}$ depends on the water chemistry and composition and structure of the steel. A value of $2.1 \times 10^{-13}$ has been proposed in NUREG-0313 for sensitized SS in water with $8 \mathrm{ppm}$ DO. For water with $0.2 \mathrm{ppm} \mathrm{DO}$, the CGR is taken as one-third that of the value given in NUREG-0313; in this case A is $7.0 \times 10^{-14}$. The value of constant $\mathrm{A}$ is smaller in low-DO environments, such as HWC BWR or PWR environments.

\subsubsection{Fracture Toughness J-R Curve Tests}

After the CGR test, a J-R test was performed on the specimen at $289^{\circ} \mathrm{C}$ in high-DO water. The test was conducted at a constant extension rate of $\approx 0.43 \mu \mathrm{m} / \mathrm{s}(0.017 \mathrm{mil} / \mathrm{s})$ in accordance with ASTM specification E-1737 for "J-Integral Characterization of Fracture Toughness." The test was interrupted periodically (by holding the specimen at constant extension) to measure the crack length. For most steels, load relaxation occurs during the hold period, which may influence the DC potential readings. Consequently, before measuring the DC potential drop at each and every hold point, the specimen was held for $\approx 30$ min to allow relaxation.

Specimen extension was monitored and controlled outside the high-temperature zone. The actual displacement of load points was determined by subtracting the extension of the load train from the measured extension. The load train displacement was determined as a function of applied load with a very stiff specimen. The J-integral was calculated from the load vs. load-line displacement curves according to the correlations for a CT specimens in ASTM Specification E 1737. The total J is the sum of the elastic and plastic components, $\mathrm{J}_{\mathrm{el}}$ and $\mathrm{J}_{\mathrm{pl}}$, respectively,

$$
\mathrm{J}=\mathrm{J}_{\mathrm{el}}+\mathrm{J}_{\mathrm{pl}} \cdot
$$

The total area and plastic component of the area $A_{p l(i)}$ at each recorded deflection are computed during the test by summing the increase in areas for each increment in deflection; the elastic component of deflection is calculated from the specimen load-line elastic compliance at each step and subtracted from the total deflection to obtain plastic deflection. The elastic component of $\mathrm{J}$, at a point corresponding to $\mathrm{a}_{\mathrm{i}}$, $\mathrm{V}_{\mathrm{i}}$, and $\mathrm{P}_{\mathrm{i}}$ on the specimen load vs. load-line displacement record, is given by

$$
\mathrm{J}_{\mathrm{el}(\mathrm{i})}=\frac{\left(\mathrm{K}_{(\mathrm{i})}\right)^{2}\left(1-v^{2}\right)}{\mathrm{E}_{\mathrm{ef}}},
$$

where the stress intensity $\mathrm{K}_{(\mathrm{i})}$ is calculated from Eqs. 5 and 7. The plastic component of $\mathrm{J}$ is given by

$$
\mathrm{J}_{\mathrm{pl}(\mathrm{i})}=\left[\mathrm{J}_{\mathrm{pl}(\mathrm{i}-1)}+\left(\frac{\eta_{(\mathrm{i}-1)}}{\mathrm{b}_{(\mathrm{i}-1)}}\right) \frac{\mathrm{A}_{\mathrm{pl}(\mathrm{i})}-\mathrm{A}_{\mathrm{pl}(\mathrm{i}-1)}}{\mathrm{B}_{\mathrm{N}}}\right]\left[1-\gamma_{(\mathrm{i}-1)} \frac{\mathrm{a}_{(\mathrm{i})}-\mathrm{a}_{(\mathrm{i}-1)}}{\mathrm{b}_{(\mathrm{i}-1)}}\right]
$$

where the factors that account for limited crack growth $\gamma_{(\mathrm{i})}$ and for the tensile component of the load $\eta_{(\mathrm{i})}$ are expressed as 


$$
\begin{aligned}
& \eta_{(i-1)}=2.0+0.552 \frac{\mathrm{b}_{(\mathrm{i}-1)}}{\mathrm{W}}, \\
& \gamma_{(\mathrm{i}-1)}=1.0+0.76 \frac{\mathrm{b}_{(\mathrm{i}-1)}}{\mathrm{W}} .
\end{aligned}
$$

In the above equation $b_{(i-1)}$ is the remaining ligament (distance from the physical crack front to the back edge of the specimen) at a point i-1.

The quantity $A_{p l(i)}-A_{p l(i-1)}$ is the increment of plastic area under the load vs. load-line displacement record between lines of constant displacement at points i-1 and i. The quantity $\mathrm{J}_{\mathrm{pl}(\mathrm{i})}$ represents the total crack-growth-corrected plastic $J$ at point $i$ and is obtained by first incrementing the existing $\mathrm{J}_{\mathrm{pl}(\mathrm{i}-1)}$ and then by modifying the total accumulated result to account for the crack growth increment. Accurate evaluations of $\mathrm{J}_{\mathrm{pl}(\mathrm{i})}$ require small uniform increments in crack growth. The plastic area under the load vs. load-line displacement record is given by

$$
A_{p l(i)}=A_{p l(i-1)}+\frac{\left[P_{i}+P_{i-1}\right]\left[V_{p l(i)}-V_{p l(i-1)}\right]}{2},
$$

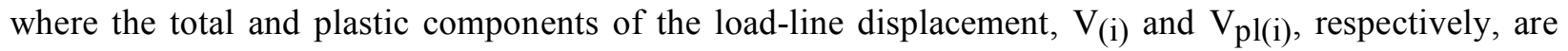
expressed as

$$
\mathrm{V}_{\mathrm{pl}(\mathrm{i})}=\mathrm{V}_{(\mathrm{i})}-\mathrm{P}_{\mathrm{i}} \mathrm{C}_{\mathrm{LL}(\mathrm{i})}
$$

where $\mathrm{C}_{\mathrm{LL}(\mathrm{i})}$ is the compliance, $(\Delta \mathrm{V} / \Delta \mathrm{P})_{\mathrm{i}}$, required to give the current crack length $\mathrm{a}_{\mathrm{i}}$. For test methods that do not use the elastic compliance techniques, $\mathrm{C}_{\mathrm{LL}(\mathrm{i})}$ can be determined from knowledge of $\mathrm{a}_{\mathrm{i}} / \mathrm{W}$, as follows:

$$
\mathrm{C}_{\mathrm{LL}(\mathrm{i})}=\frac{\left[1.62+17.80\left(\mathrm{a}_{\mathrm{i}} / \mathrm{W}\right)-4.88\left(\mathrm{a}_{\mathrm{i}} / \mathrm{W}\right)^{2}+1.27\left(\mathrm{a}_{\mathrm{i}} / \mathrm{W}\right)^{3}\right]}{\mathrm{E}^{\prime} \mathrm{B}_{\mathrm{e}}\left[1-\left(\mathrm{a}_{\mathrm{i}} / \mathrm{W}\right)\right]^{2}}
$$

where $B_{e}$ is specimen effective thickness given by $B-\left(B-B_{N}\right)^{2} / B$ and $E^{\prime}=E /\left(1-v^{2}\right)$.

After the test the final crack size was marked by fatigue cycling in air at room temperature. The specimens were then fractured, and the fracture surface of both halves of the specimen was photographed with a telephoto lens through the hot cell window. The final crack length of each half of the fractured specimen was determined from the optical photograph by the $9 / 8$ averaging technique. In this technique, nine measurements were taken across the width of the specimen at equal intervals, the two near-surface measurements were averaged, and the resultant value was averaged with the remaining seven measurements. The crack extensions determined from the DC potential drop method were proportionately scaled to match the final optically measured crack length.

The experimental results from the J-R curve test were analyzed in accordance with ASTM E-1737 to obtain the fracture toughness J-R curve. The DC potential data were corrected to account for the 
effects of plasticity on the measured potential, since large crack-tip plasticity can increase the measured potentials due to resistivity increases without crack extension. As per ASTM E1737, the change in potential before crack initiation was ignored, and the remainder of the potential change was used to establish the J-R curve. The normalized potential varies linearly with load-line displacement until the onset of crack extension. For all data prior to the loss in linearity, crack extension was expressed as $\mathrm{a}_{\mathrm{O}}+\Delta \mathrm{a}_{\mathrm{B}}$, where $\mathrm{a}_{\mathrm{O}}$ is the initial crack length, and the crack extension $\Delta \mathrm{a}_{\mathrm{B}}$ is calculated from the blunting line relationship $\Delta \mathrm{a}=\mathrm{J} /\left(4 \sigma_{\mathrm{f}}\right)$. For all data after this point, crack length was calculated from Eq. 4 , in which $\mathrm{U}_{0}$ is considered to be the potential at the onset of crack extension in the potential vs. load-linedisplacement plot (i.e., at $\Delta \mathrm{a}_{\mathrm{B}}$ crack extension).

The use of the blunting line given by $\Delta \mathrm{a}=\mathrm{J} /\left(4 \sigma_{\mathrm{f}}\right)$ is not consistent with ASTM E 813 , which specifies a slope of two times the effective yield stress (or flow stress) for the blunting line. However, for high-strain-hardening materials, such as austenitic SSs, a slope that is four times the flow stress $\left(4 \sigma_{f}\right)$ represents the blunting line better than the slope of $2 \sigma_{\mathrm{f}}$ defined in ASTM E 1737.61,62 In irradiated materials, the increase in yield stress is primarily due to a high density of barriers to dislocation motion. During deformation, as dislocations sweep through the irradiated matrix, they annihilate the very fine scale of barriers, thus creating a "channel" for easy dislocation motion. As discussed in Section 4.3.1, this condition may result in marked work softening and produce a distinctive change in fracture mode. As discussed in Section 2.3.1, to account for the possible strain softening that may occur in irradiated materials, an effective flow stress, defined as the average of the nonirradiated and irradiated flow stress, ${ }^{56}$ was used in the J-R curve data analysis. Because the effective flow stress discounts the irradiationinduced increase in flow stress by a factor of two, the slope of the blunting line was defined as $4 \sigma_{\mathrm{f}}$ even for the irradiated materials. 


\section{Test Results}

In earlier ANL studies, CGR tests were completed in simulated BWR environments at $289^{\circ} \mathrm{C}$ with the following: Types 304L and 316L SS (Heats C3 and C16, respectively) irradiated to 0.45, 1.35, and $3.0 \mathrm{dpa}$ and Types 304 and 304L weld HAZ irradiated to $0.75 \mathrm{dpa}$. The CGR data from earlier studies are given in Appendix A of this report, Tables A1-A12.

Fracture toughness tests were also completed in air on Types 304 and 316L SS (Heats C19 and C16, respectively) irradiated 3.0 dpa. However, as discussed in Section 2.3.1, because the experimental data from the J-R curve tests performed earlier ${ }^{27}$ were analyzed by using the correlations for a discshaped specimen instead of a standard CT specimen, the earlier data have been corrected using Eqs. 5-7. The corrected fracture toughness J-R curve data are compiled in Appendix B of this report, Tables B1-B4.

\subsection{Types 304 and 316 Stainless Steel}

Crack growth tests have been completed in BWR environments at $289^{\circ} \mathrm{C}$ on $1 / 4-\mathrm{T}$ CT specimens of Type $316 \mathrm{SS}$ (Heat C21) irradiated to $\approx 0.45,1.35$, and $3.00 \mathrm{dpa}$, as well as sensitized Type 304 SS (Heat 10285) irradiated to $\approx 2.16 \mathrm{dpa}$. The test on sensitized Type $304 \mathrm{SS}$ included a fracture toughness $\mathrm{J}-\mathrm{R}$ curve test conducted in high-DO water at $289^{\circ} \mathrm{C}$, after the CGR test. The significant results for the various tests are summarized below.

\subsubsection{Specimen C21-A of Type 316 SS, Test CGRI-25}

The test on Specimen C21-A of Type 316 SS irradiated to 0.45 dpa was started in high-purity water with $\approx 350 \mathrm{ppb}$ DO and a flow rate of $\approx 20 \mathrm{~mL} / \mathrm{min}$. The specimen was fatigue precracked at $\mathrm{R}=0.35$, $\mathrm{K}_{\max }=15.5 \mathrm{MPa} \mathrm{m}{ }^{1 / 2}$, triangular waveform, and $1-\mathrm{Hz}$ frequency. After $\approx 0.20$-mm crack advance, $\mathrm{R}$ was increased incrementally to 0.7 , and the waveform was changed to a slow/fast sawtooth with rise times of 30-1000 s. Finally, the specimen was subjected to a constant load with and without periodic partial unloading. At $\approx 162 \mathrm{~h}$ the test was interrupted because of a power bump that tripped the autoclave temperature control unit and the water pump. The cessation of water flow caused overheating of the ECP-cell unit, which damaged the reference electrode. The test was restarted with the ECP cell bypassed; ECP measurements were not obtained for the remainder of the test. There was no chloride intrusion during the interruption, and test conditions prior to the interruption were restored.

After the test the final crack size was marked by fatigue cycling in air at room temperature. The specimen was then fractured; a photograph of the fracture surfaces is shown in Fig. 9. The final crack length measured from the photograph of each half of the specimen was $\approx 23 \%$ greater than the value determined from the DC potential measurements. The experimental crack extensions were scaled proportionately. The environmental and loading conditions, corrected CGRs, and the allowed $\mathrm{K}_{\max }$ based on the $\mathrm{K} /$ size criterion are given in Table 4; the changes in crack length, CGR, and $\mathrm{K}_{\max }$ with time during the various test periods are plotted in Fig. 10. 


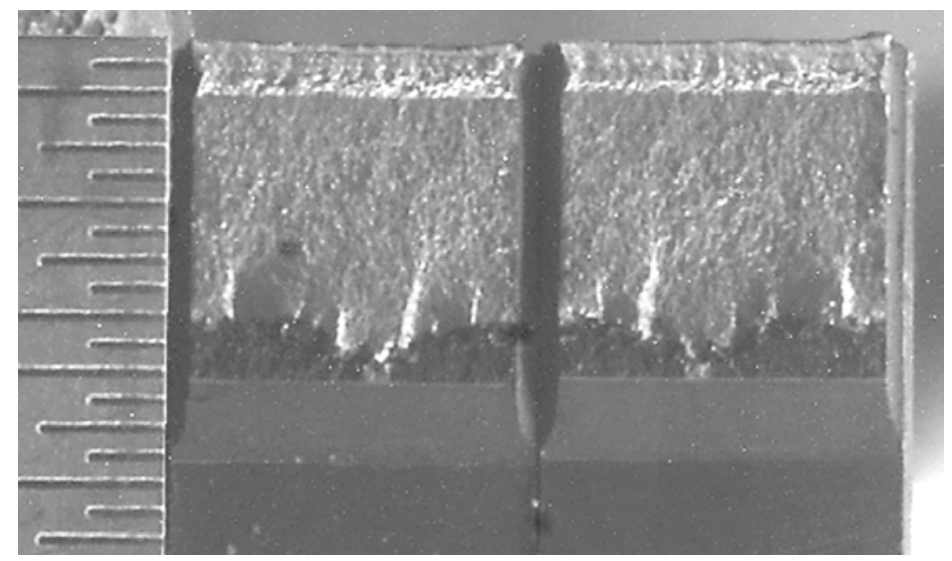

Figure 9.

Photograph of the fracture surfaces of the two halves of the fractured specimen C21-A.

Table 4. Test conditions and results for Specimen C21-A of Type 316 SS in BWR water at $289^{\circ} \mathrm{C}$.

\begin{tabular}{|c|c|c|c|c|c|c|c|c|c|c|c|c|c|}
\hline $\begin{array}{c}\text { Test } \\
\text { Period }\end{array}$ & $\begin{array}{c}\text { Test } \\
\text { Time, } \\
\mathrm{h}\end{array}$ & $\begin{array}{c}\mathrm{E} \\
\mathrm{mV} \\
\mathrm{Pt} \\
\end{array}$ & $\begin{array}{l}\mathrm{P} \\
\mathrm{HE}) \\
\text { Steel }\end{array}$ & $\begin{array}{c}\mathrm{O}_{2},{ }^{b} \\
\text { Conc., } \\
\text { ppb }\end{array}$ & $\begin{array}{c}\mathrm{R} \\
\text { Load } \\
\text { Ratio } \\
\end{array}$ & $\begin{array}{c}\text { Rise } \\
\text { Time, } \\
\mathrm{s} \\
\end{array}$ & $\begin{array}{c}\text { Return } \\
\text { Time, } \\
\mathrm{s} \\
\end{array}$ & $\begin{array}{c}\text { Hold } \\
\text { Time, } \\
\mathrm{s} \\
\end{array}$ & $\begin{array}{c}\mathrm{K}_{\max }, \\
\mathrm{MPa} \mathrm{m}^{1 / 2}\end{array}$ & $\begin{array}{c}\Delta \mathrm{K}, \\
\mathrm{MPa} \mathrm{m}^{1 / 2}\end{array}$ & $\begin{array}{c}\text { Growth } \\
\text { Rate, } \\
\text { m/s }\end{array}$ & $\begin{array}{c}\text { Allowed } \\
\mathrm{K}_{\max }{ }^{c} \\
\mathrm{MPa} \mathrm{m}^{1 / 2}\end{array}$ & $\begin{array}{c}\text { Crack } \\
\text { Length, }{ }^{\mathrm{d}} \\
\mathrm{mm}\end{array}$ \\
\hline Pre a & 95 & - & - & 350 & 0.35 & 0.5 & 0.5 & 0 & 15.5 & 10.1 & $1.10 \mathrm{E}-08$ & 22.2 & $\begin{array}{l}6.000 \\
6.138\end{array}$ \\
\hline Pre b & 112 & 249 & 103 & 350 & 0.34 & 5 & 5 & 0 & 15.7 & 10.3 & 5.69E-09 & 22.0 & 6.244 \\
\hline 1 & 157 & 246 & 116 & 350 & 0.51 & 30 & 4 & 0 & 16.0 & 7.9 & 1.33E-09 & 21.7 & 6.410 \\
\hline 2 & 232 & $\mathrm{e}$ & $\mathrm{e}$ & 350 & 0.53 & 300 & 12 & 0 & 16.1 & 7.6 & $3.82 \mathrm{E}-10$ & 21.5 & 6.497 \\
\hline 3 & 331 & e & e & 350 & 0.69 & 300 & 12 & 0 & 16.2 & 5.0 & $1.10 \mathrm{E}-10$ & 21.4 & 6.544 \\
\hline 4 & 474 & $\mathrm{e}$ & $\mathrm{e}$ & 350 & 0.70 & 1,000 & 12 & 0 & 16.3 & 4.9 & $5.84 \mathrm{E}-11$ & 21.3 & 6.571 \\
\hline 5 & 570 & e & e & 350 & 0.70 & 12 & 12 & 3600 & 16.5 & 5.0 & $1.51 \mathrm{E}-10$ & 21.2 & 6.622 \\
\hline 6 & 695 & e & e & 350 & 0.70 & 12 & 12 & 3600 & 21.8 & 6.5 & $2.46 \mathrm{E}-10$ & 21.0 & 6.748 \\
\hline 7 & 835 & $\mathrm{e}$ & $\mathrm{e}$ & 350 & 1.00 & - & - & - & 22.7 & - & $2.56 \mathrm{E}-10$ & 20.7 & 6.883 \\
\hline
\end{tabular}

${ }^{\text {a }}$ Type 316 SS Heat C21, irradiated to $0.3 \times 10^{21} \mathrm{n} / \mathrm{cm}^{2}(0.45 \mathrm{dpa})$ at $\approx 288^{\circ} \mathrm{C}$.

${ }^{b}$ Represents values in the effluent. Conductivity and DO were $\approx 0.07 \mu \mathrm{S} / \mathrm{cm}$ and $500 \mathrm{ppb}$, respectively, in the feedwater.

${ }^{c}$ Based on effective flow stress, defined as the average of irradiated and nonirradiated flow stresses.

${ }^{d}$ Actual crack extension was $23 \%$ greater than the value determined from the DC potential drop measurements.

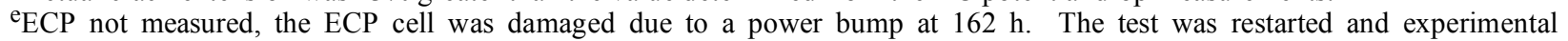
conditions were restored; there was no chloride intrusion during the interruption.

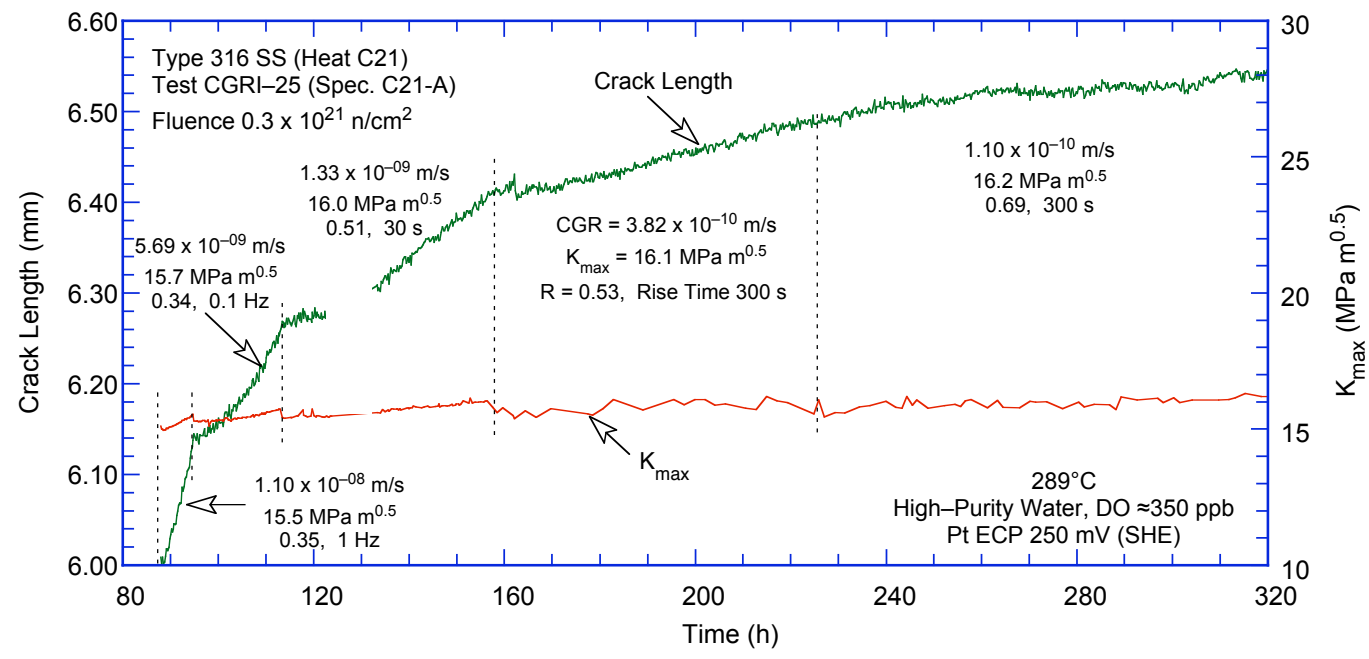

(a)

Figure 10. Crack-length-vs.-time plot for Type $316 \mathrm{SS}$ in BWR water at $288^{\circ} \mathrm{C}$ during test periods (a) precracking-3, (b) 4-5, and (c) 6-7. 


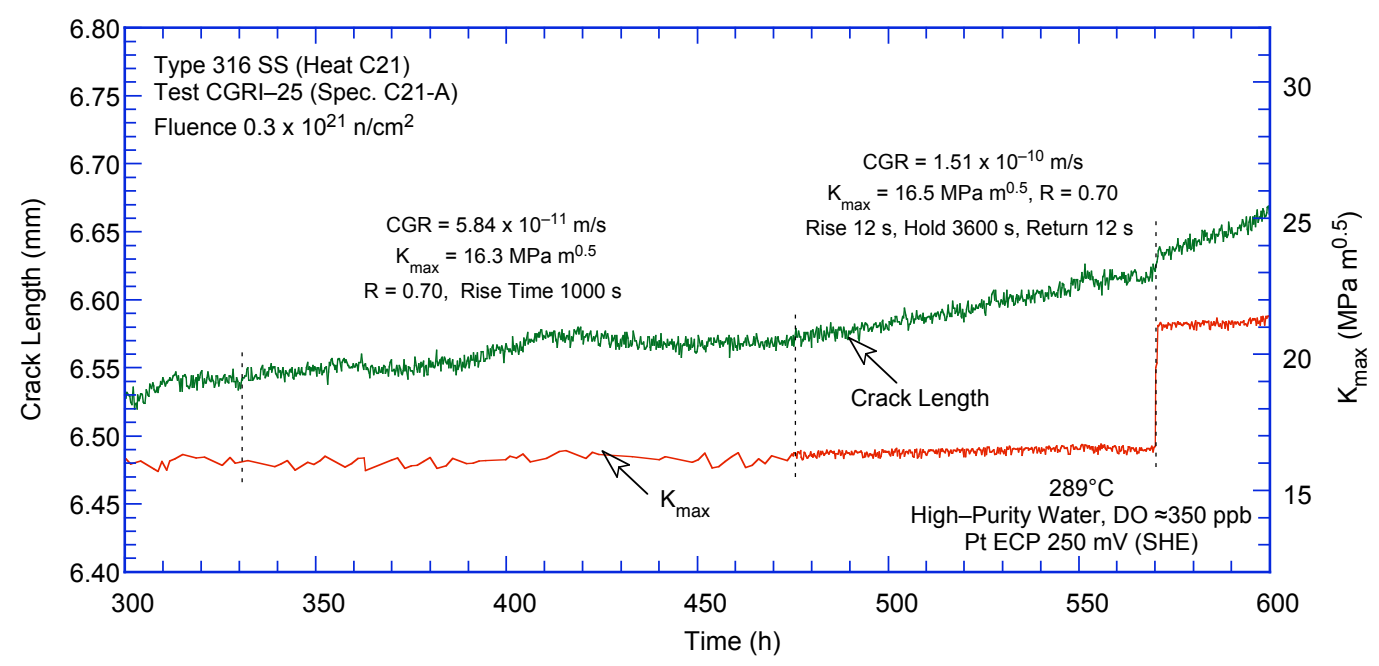

(b)

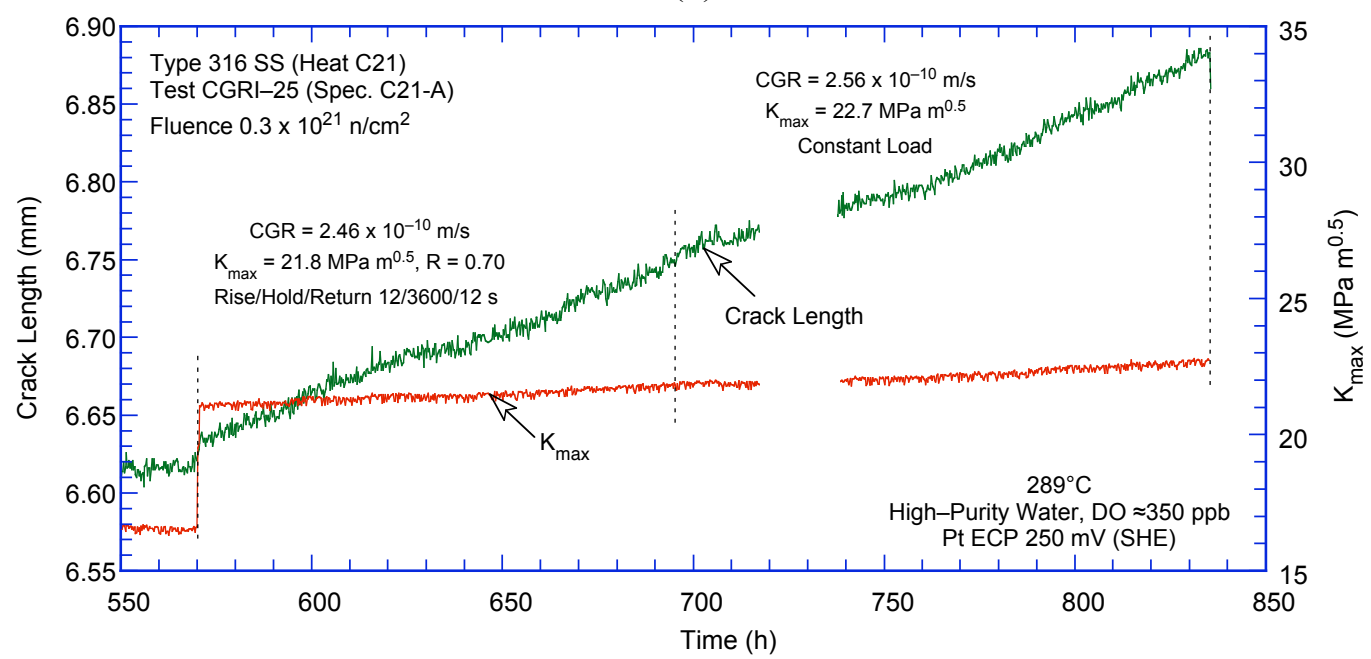

(c)

Figure 10. (Contd.)

\subsubsection{Specimen C21-B of Type 316 SS, Test CGRI-24}

The test on Specimen C21-B of Type 316 SS irradiated to 1.35 dpa was started in high-purity water with $\approx 350 \mathrm{ppb}$ DO and a flow rate of $\approx 34 \mathrm{~mL} / \mathrm{min}$. The specimen was fatigue precracked at $\mathrm{R}=0.33$, $\mathrm{K}_{\max }=15.9 \mathrm{MPa} \mathrm{m}{ }^{1 / 2}$, triangular waveform, and $1-\mathrm{Hz}$ frequency. Initially, the crack length data were lost for about $24 \mathrm{~h}$ because of a malfunction in the DC potential drop system. After $\approx 0.3$-mm crack advance, $\mathrm{R}$ was increased incrementally to 0.7 , and the waveform was changed to a slow/fast sawtooth with rise times of 300 or $1000 \mathrm{~s}$ and a return time of $12 \mathrm{~s}$.

At $\approx 245 \mathrm{~h}$ the DO level in the feedwater was decreased from $\approx 350 \mathrm{ppb}$ to $<30 \mathrm{ppb}$ by purging the feedwater tank with a mixture of $\mathrm{N}_{2}+5 \% \mathrm{H}_{2}$. The change in crack length and ECP of the Pt and SS electrodes during the transient period is shown in Fig. 11. The ECP of the Pt electrode decreased to below $-450 \mathrm{mV}$ (SHE) within 3-4 h, while the ECP of the SS electrode took nearly $20 \mathrm{~h}$ to decrease to $-200 \mathrm{mV}$ (SHE), although it eventually decreased to less than $-400 \mathrm{mV}$. Crack growth rates dropped significantly in the low DO environment. The test was terminated after $557 \mathrm{~h}$. 


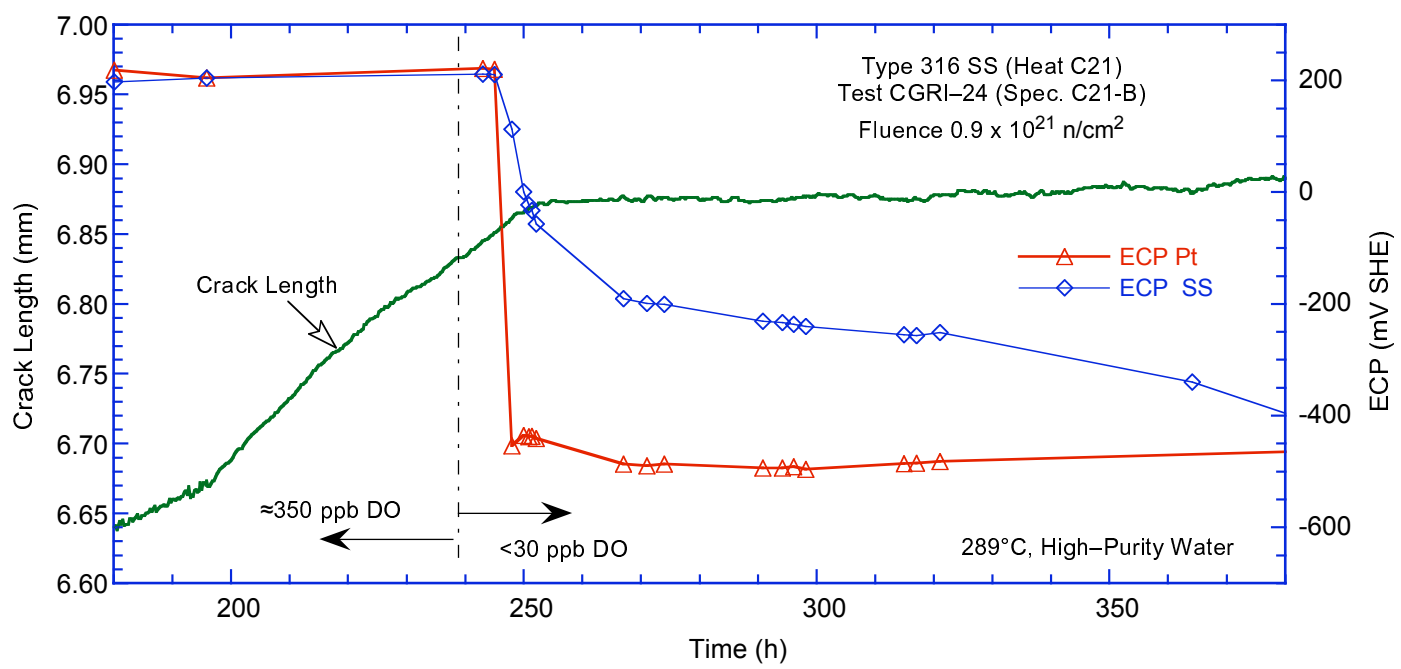

Figure 11. Change in crack length and ECP of Pt and SS electrodes during test periods 5-6 and the intermediate transition period.

After the CGR test, the final crack front was marked by fatigue cycling at room temperature in air. The specimen was then fractured; a photograph of the fracture surface is shown in Fig. 12. The final crack length, measured from the photograph, showed good agreement with the values estimated from the DC potential drop measurements; the difference in measured and estimated crack lengths was $<5 \%$. The environmental and loading conditions, corrected CGRs, and the allowed $\mathrm{K}_{\max }$ based on the $\mathrm{K} /$ size criterion are given in Table 5; the changes in crack length, CGR, and $\mathrm{K}_{\max }$ with time during the various test periods are plotted in Fig. 13. For this specimen, the K/size criterion was satisfied for all loading conditions.

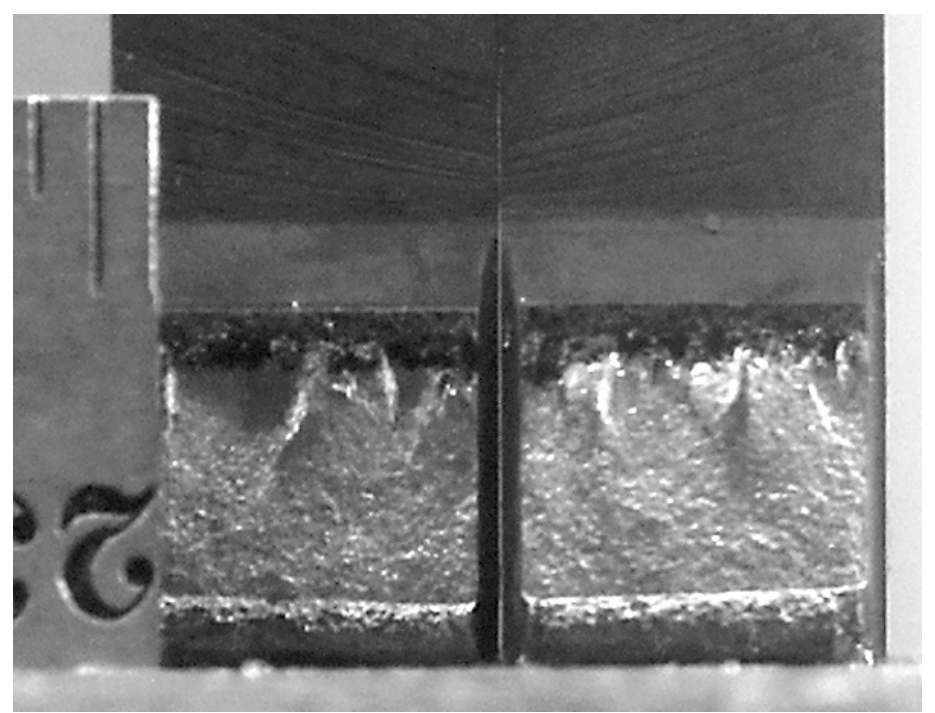

Figure 12.

Photomicrographs of the fracture surface of Specimen C21-B. 
Table 5. Test conditions and results for Specimen C21-Ba of Type 316 SS in BWR water at $289^{\circ} \mathrm{C}$.

\begin{tabular}{|c|c|c|c|c|c|c|c|c|c|c|c|c|c|}
\hline $\begin{array}{c}\text { Test } \\
\text { Period } \\
\end{array}$ & $\begin{array}{c}\text { Test } \\
\text { Time, } \\
\mathrm{h}\end{array}$ & $\begin{array}{r}\mathrm{E} \\
\mathrm{mV} \\
\mathrm{Pt} \\
\end{array}$ & $\begin{array}{l}\mathrm{P} \\
\mathrm{S} H E) \\
\text { Steel } \\
\end{array}$ & $\begin{array}{c}\mathrm{O}_{2},{ }^{b} \\
\text { Conc., } \\
\text { ppb }\end{array}$ & $\begin{array}{c}\mathrm{R} \\
\text { Load } \\
\text { Ratio } \\
\end{array}$ & $\begin{array}{c}\text { Rise } \\
\text { Time, } \\
\mathrm{s} \\
\end{array}$ & $\begin{array}{c}\text { Return } \\
\text { Time, } \\
\text { s } \\
\end{array}$ & $\begin{array}{c}\text { Hold } \\
\text { Time, } \\
\mathrm{s} \\
\end{array}$ & $\begin{array}{c}\mathrm{K}_{\max }, \\
\mathrm{MPa} \mathrm{m}^{1 / 2}\end{array}$ & $\begin{array}{c}\Delta \mathrm{K}, \\
\mathrm{MPa} \mathrm{m}^{1 / 2}\end{array}$ & $\begin{array}{c}\text { Growth } \\
\text { Rate, } \\
\text { m/s }\end{array}$ & $\begin{array}{c}\text { Allowed } \\
\mathrm{K}_{\max }{ }^{\mathrm{c}} \\
\mathrm{MPa} \mathrm{m}^{1 / 2}\end{array}$ & $\begin{array}{c}\text { Crack } \\
\text { Length, } \\
\mathrm{mm}\end{array}$ \\
\hline Pre & 7 & - & - & 350 & 0.33 & 0.5 & 0.5 & 0 & 15.9 & 10.6 & $2.63 \mathrm{E}-08$ & 21.9 & $\begin{array}{l}6.000 \\
6.312\end{array}$ \\
\hline $1^{\mathrm{e}}$ & 24 & 268 & 151 & 350 & 0.52 & 300 & 12 & 0 & - & - & - & - & - \\
\hline $2 \mathrm{a}^{\mathrm{e}}$ & 30 & 267 & 166 & 350 & 0.50 & 12 & 2 & 0 & - & - & - & - & - \\
\hline $2 b$ & 77 & 231 & 185 & 350 & 0.50 & 300 & 12 & 0 & 16.0 & 8.0 & $5.85 \mathrm{E}-10$ & 21.7 & 6.458 \\
\hline 3 & 124 & 221 & 191 & 350 & 0.71 & 300 & 12 & 0 & 16.3 & 4.7 & $5.40 \mathrm{E}-10$ & 21.5 & 6.551 \\
\hline 4 & 196 & 204 & 204 & 350 & 0.70 & 1000 & 12 & 0 & 16.2 & 4.9 & $4.91 \mathrm{E}-10$ & 21.2 & 6.670 \\
\hline 5 & 255 & 221 & 211 & 350 & 1.00 & - & - & 0 & 16.2 & - & $9.67 \mathrm{E}-10$ & 20.8 & 6.872 \\
\hline 6 & 395 & -485 & -452 & $<30$ & 1.00 & - & - & 0 & 16.3 & - & $3.32 \mathrm{E}-11$ & 20.8 & 6.889 \\
\hline 7 & 557 & -512 & -551 & $<30$ & 1.00 & - & - & 0 & 19.6 & - & $1.24 \mathrm{E}-11$ & 20.8 & 6.914 \\
\hline
\end{tabular}

${ }^{\text {a }}$ Type 316 SS Heat C21, irradiated to $0.9 \times 10^{21} \mathrm{n} / \mathrm{cm}^{2}(1.35 \mathrm{dpa})$ at $\approx 288^{\circ} \mathrm{C}$.

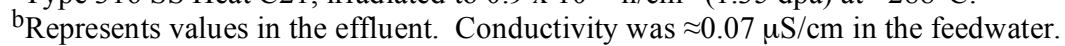

${ }^{\mathrm{c}}$ Based on effective yield stress, defined as the average of irradiated and nonirradiated yield stresses.

${ }^{\mathrm{d}}$ The difference between the measured crack extension and that determined from the DC potential drop measurements was $<5 \%$.

${ }^{\mathrm{e}} \mathrm{Crack}$ length could not be determined because of a malfunction in the DC potential system.

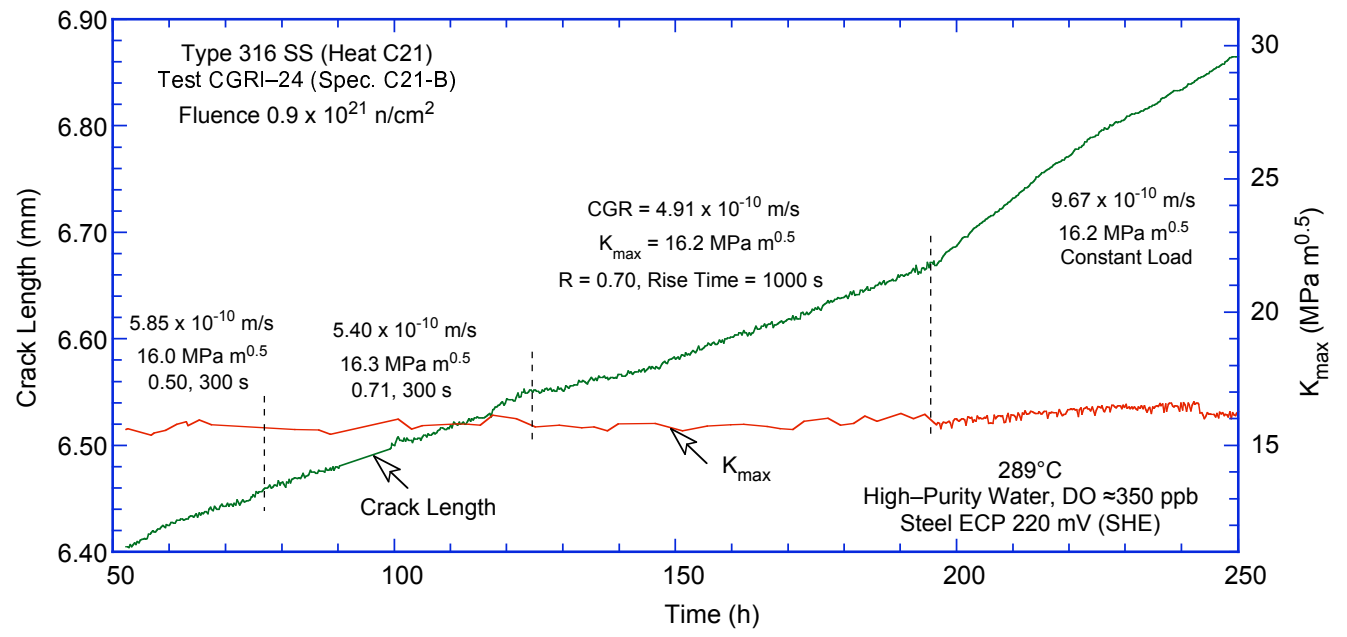

(a)

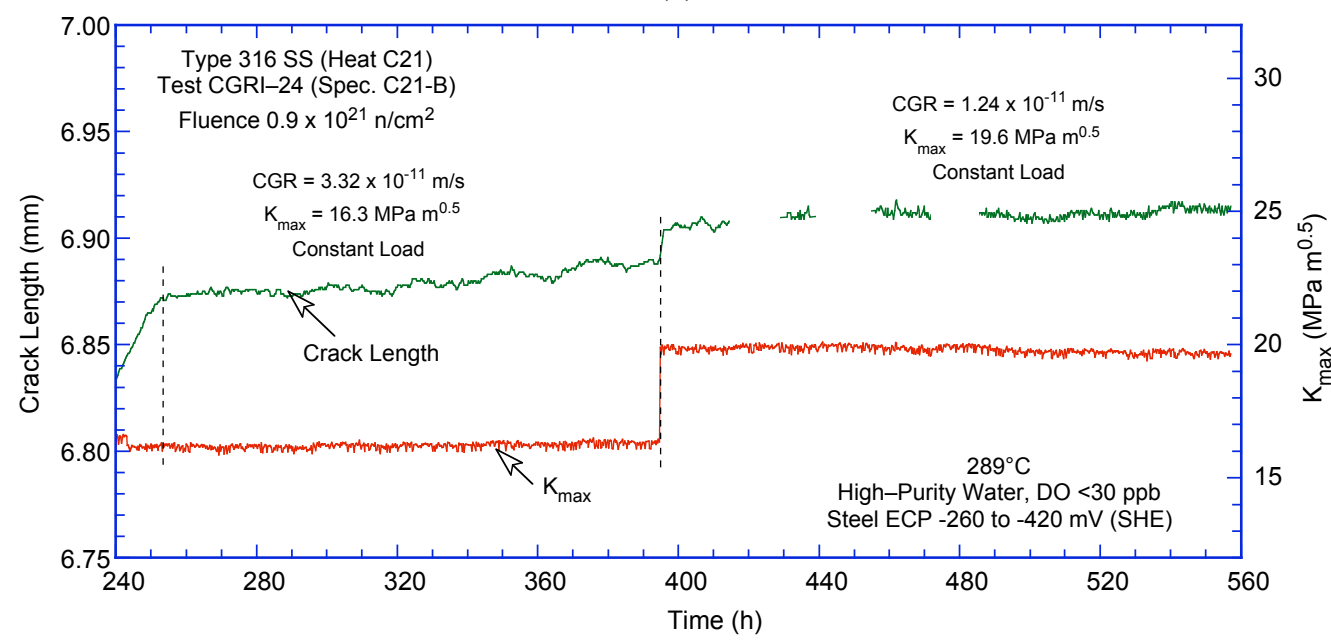

(b)

Figure 13. Crack-length-vs.-time plot for Type $316 \mathrm{SS}$ in BWR water at $288^{\circ} \mathrm{C}$ during test periods (a) precraking-5 and (b) 6-7. 


\subsubsection{Specimen C21-C of Type 316 SS, Test CGRI-26}

The test on Specimen C21-C of Type 316 SS irradiated to 3.0 dpa was started in high-purity water with $\approx 500 \mathrm{ppb} \mathrm{DO}$ and a flow rate of $27 \mathrm{~mL} / \mathrm{min}$. The specimen was fatigue precracked at $\mathrm{R}=0.33$, $\mathrm{K}_{\max }=15.5 \mathrm{MPa} \mathrm{m}{ }^{1 / 2}$, triangular waveform, and $1-\mathrm{Hz}$ frequency. After $\approx 0.4-\mathrm{mm}$ crack advance, $\mathrm{R}$ was increased incrementally to 0.7 , and the waveform was changed to a slow/fast sawtooth with rise times of 30-1000 s. Finally, the specimen was subjected to a constant load. At $450 \mathrm{~h}$, the CGR increased rapidly by a factor of $\approx 6$ (Fig. $14 \mathrm{~b}$ ); considering that the applied $\mathrm{K}_{\max }$ for the test period may have exceeded the specimen size criterion, the test was terminated at $510 \mathrm{~h}$.

The DO level in the effluent was decreased after $96 \mathrm{~h}$ from $\approx 500 \mathrm{ppb}$ to $<20 \mathrm{ppb}$, then at $192 \mathrm{~h}$ it was increased to $\approx 450 \mathrm{ppb}$, and finally at $318 \mathrm{~h}$ it was again decreased below $20 \mathrm{ppb}$. The change in crack length and ECP of the Pt and SS electrodes during the transient periods is shown in Fig. 14. During the first change, the ECP of the Pt electrode decreased to below $-450 \mathrm{mV}$ (SHE) rather rapidly while the ECP of the SS electrode took nearly a day to decrease below $-200 \mathrm{mV}$ (SHE); it eventually decreased to about $-400 \mathrm{mV}$. The CGR decreased significantly in the low-DO water (Fig. 14a); the change in CGR is abrupt and appears to have occurred when the ECP of the SS electrode decreased to about $-200 \mathrm{mV}$. Similarly, when the DO content was increased from $<20 \mathrm{ppb}$ to $\approx 400 \mathrm{ppb}$, although the ECP of the Pt

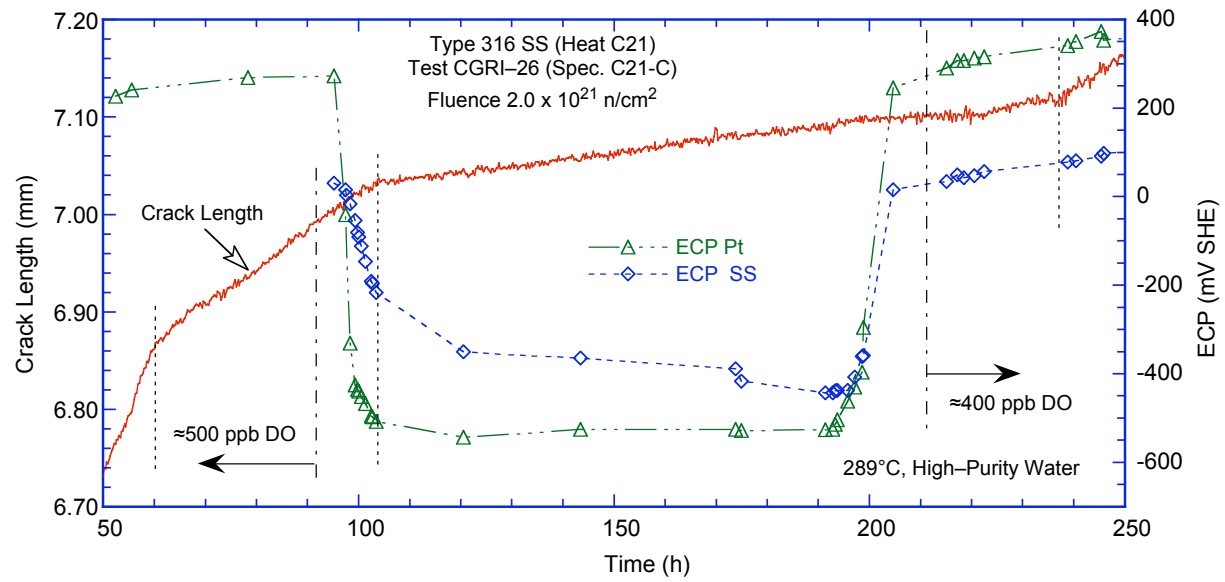

(a)

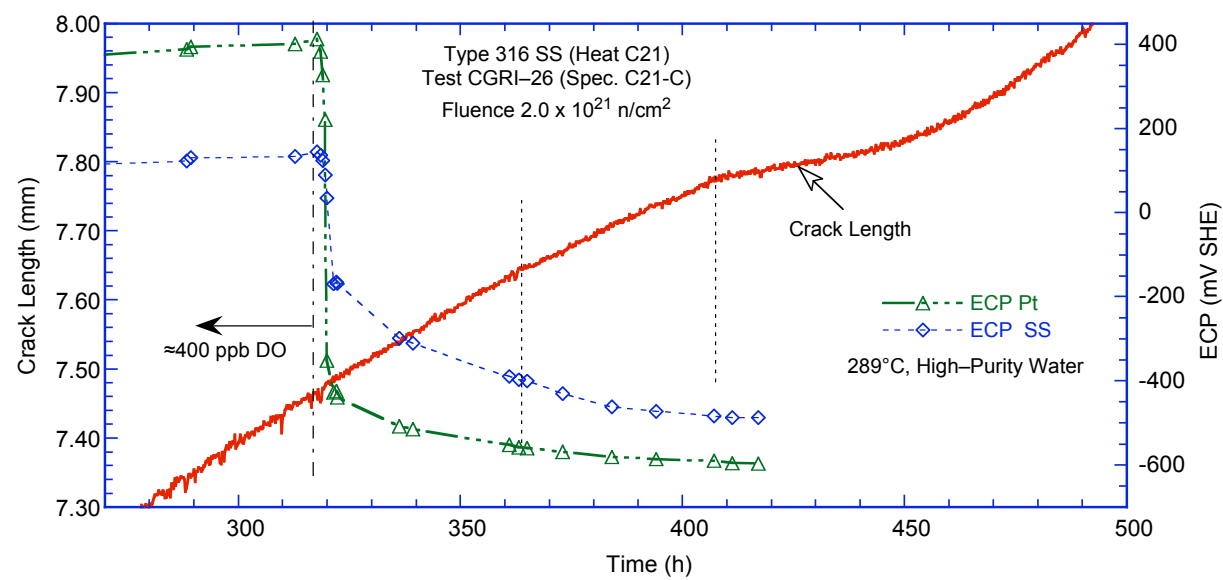

(b)

Figure 14. Change in crack length and ECP of Pt and SS electrodes during test periods (a) 3-5 and (b) 7-9. 
electrode had increased above $250 \mathrm{mV}$ at $\approx 200 \mathrm{~h}$, the CGR increased at $238 \mathrm{~h}$ when the ECP of the SS electrode increased above $\approx 100 \mathrm{mV}$ (Fig. 14a).

The crack growth behavior during the second decrease in the DO level at $318 \mathrm{~h}$ (Fig. 14b) was different from that during the first decrease in DO level. The CGR did not decrease for nearly $100 \mathrm{~h}$, even after the SS ECP had decreased below $-400 \mathrm{mV}$ (SHE). The reason for the different behavior during the second decrease in the DO level is not clear. The applied $\mathrm{K}_{\max }$ during the change in DO (from $\approx 270$ $360 \mathrm{~h}$ ) was $23.6-24.9 \mathrm{MPa} \mathrm{m}{ }^{1 / 2}$, which is equal to or marginally above the value allowed by the $\mathrm{K} /$ size criterion based on effective flow stress. To ensure compliance with the $\mathrm{K} /$ size criterion, $\mathrm{K}_{\max }$ was gradually decreased from $\approx 25.0$ to $20.0 \mathrm{MPa} \mathrm{m}^{1 / 2}$. The CGR decreased for about a day (Fig. 14b) and then increased back to approximately the growth rate prior to the decrease in $\mathrm{K}_{\max }$.

After the test the final crack size was marked by fatigue cycling in air at room temperature. The specimen was then fractured; a photograph of the fracture surfaces is shown in Fig. 15. The final crack length was $\approx 69 \%$ greater than the value determined from the DC potential measurements. The experimental crack extensions were scaled proportionately. The environmental and loading conditions, corrected CGRs, and allowed $\mathrm{K}_{\max }$ based on the $\mathrm{K} /$ size criterion are given in Table 6 ; the changes in crack length, CGR, and $\mathrm{K}_{\max }$ with time during the various test periods are plotted in Fig. 16.

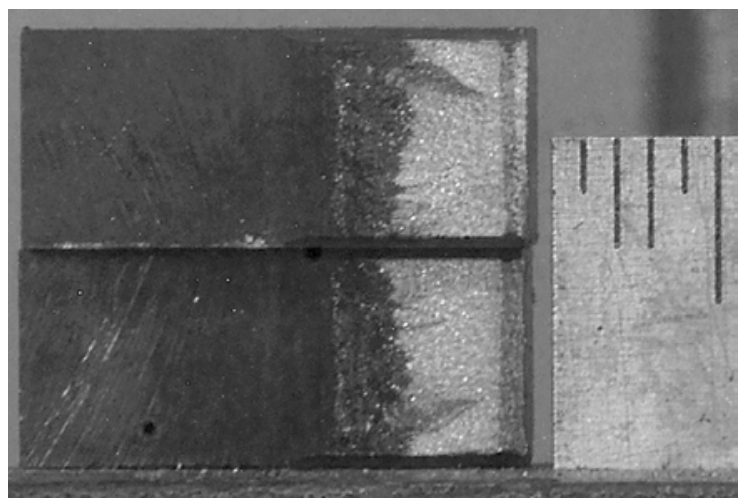

Figure 15.

Photograph of the fracture surfaces of the two halves of the fractured specimen C21-C.

Table 6. Test conditions and results for Specimen C21-Ca of Type 316 SS in BWR water at $289^{\circ} \mathrm{C}$.

\begin{tabular}{|c|c|c|c|c|c|c|c|c|c|c|c|c|c|}
\hline $\begin{array}{c}\text { Test } \\
\text { Period }\end{array}$ & $\begin{array}{c}\text { Test } \\
\text { Time, } \\
\mathrm{h}\end{array}$ & $\begin{array}{c}\mathrm{E} \\
\mathrm{mV} \\
\mathrm{Pt}\end{array}$ & $\begin{array}{l}\mathrm{P}^{\mathrm{b}} \\
\text { SHE) } \\
\text { Steel }\end{array}$ & $\begin{array}{c}\mathrm{O}_{2} \\
\text { Conc., } \\
\text { ppb }\end{array}$ & $\begin{array}{c}\text { R } \\
\text { Load } \\
\text { Ratio } \\
\end{array}$ & $\begin{array}{c}\text { Rise } \\
\text { Time, } \\
\mathrm{s}\end{array}$ & $\begin{array}{c}\text { Return } \\
\text { Time, } \\
\text { s }\end{array}$ & $\begin{array}{l}\text { Hold } \\
\text { Time, } \\
\text { s }\end{array}$ & $\begin{array}{c}\mathrm{K}_{\max }, \\
\mathrm{MPa} \mathrm{m}^{1 / 2}\end{array}$ & $\begin{array}{c}\Delta \mathrm{K}, \\
\mathrm{MPa} \mathrm{m}^{1 / 2}\end{array}$ & $\begin{array}{c}\text { Growth } \\
\text { Rate, } \\
\mathrm{m} / \mathrm{s}\end{array}$ & $\begin{array}{c}\text { Allowed } \\
\mathrm{K}_{\max }{ }^{\mathrm{c}} \\
\mathrm{MPa} \mathrm{m}^{1 / 2}\end{array}$ & $\begin{array}{c}\text { Crack } \\
\text { Length, } \\
\mathrm{mm}\end{array}$ \\
\hline & & & & & & & & & & & & & 6.000 \\
\hline Pre & 7 & $\mathrm{e}$ & $\mathrm{e}$ & 500 & 0.33 & 0.5 & 0.5 & 0 & 15.5 & 10.4 & $4.87 \mathrm{E}-08$ & 27.7 & 6.404 \\
\hline 1 & 29 & 249 & e & 500 & 0.52 & 30 & 5 & 0 & 15.7 & 7.5 & $3.12 \mathrm{E}-09$ & 27.4 & 6.528 \\
\hline 2 & 48 & 227 & $\mathrm{e}$ & 500 & 0.51 & 300 & 4 & 0 & 16.5 & 8.1 & $2.84 \mathrm{E}-09$ & 26.9 & 6.708 \\
\hline 3 & 56 & 241 & $\mathrm{e}$ & 500 & 0.71 & 1000 & 12 & 0 & 17.0 & 4.9 & $3.22 \mathrm{E}-09$ & 26.7 & 6.797 \\
\hline 4 & 103 & 241 & e & 500 & 1.00 & - & - & - & 17.6 & - & $1.06 \mathrm{E}-09$ & 26.1 & 7.025 \\
\hline 5 & 237 & -507 & -216 & $<30$ & 1.00 & - & - & - & 17.9 & - & $1.77 \mathrm{E}-10$ & 25.9 & 7.116 \\
\hline 6 & 266 & 379 & 114 & 450 & 1.00 & - & - & - & 18.1 & - & $9.18 \mathrm{E}-10$ & 25.6 & 7.212 \\
\hline 7 & 321 & 328 & 124 & 450 & 1.00 & - & - & - & 23.6 & - & $1.21 \mathrm{E}-09$ & 24.9 & 7.480 \\
\hline 8 & 360 & -551 & -389 & $<30$ & 1.00 & - & - & - & 24.9 & - & $1.06 \mathrm{E}-09$ & 24.5 & 7.631 \\
\hline $9 \mathrm{a}$ & 409 & -590 & -483 & $<30$ & 1.00 & - & - & - & $23.3^{f}$ & - & $7.85 \mathrm{E}-10$ & 24.1 & 7.774 \\
\hline $9 b$ & 442 & -596 & -487 & $<30$ & 1.00 & - & - & - & $20.8^{\mathrm{f}}$ & - & $3.12 \mathrm{E}-10$ & 23.9 & 7.814 \\
\hline $9 \mathrm{c}$ & 506 & - & - & $<30$ & 1.00 & - & - & - & 22.1 & - & $1.80 \mathrm{E}-09$ & 23.1 & 8.097 \\
\hline
\end{tabular}

${ }^{a}$ Type 316 SS Heat C21, irradiated to $2.0 \times 10^{21} \mathrm{n} / \mathrm{cm}^{2}(3.0 \mathrm{dpa})$ at $\approx 288^{\circ} \mathrm{C}$.

${ }^{b}$ Represents values in the effluent. Conductivity and DO were $\approx 0.07 \mu \mathrm{S} / \mathrm{cm}$ and $600 \mathrm{ppb}$, respectively, in the feedwater.

${ }^{\mathrm{c}}$ Based on effective yield stress, defined as the average of irradiated and nonirradiated yield stresses.

${ }^{d}$ Actual crack extension was $69 \%$ greater than the value determined from the DC potential drop measurements.

eNot measured.

${ }^{f} K_{\max }$ was decreased during the test period; the listed value represents the average value for the period. 


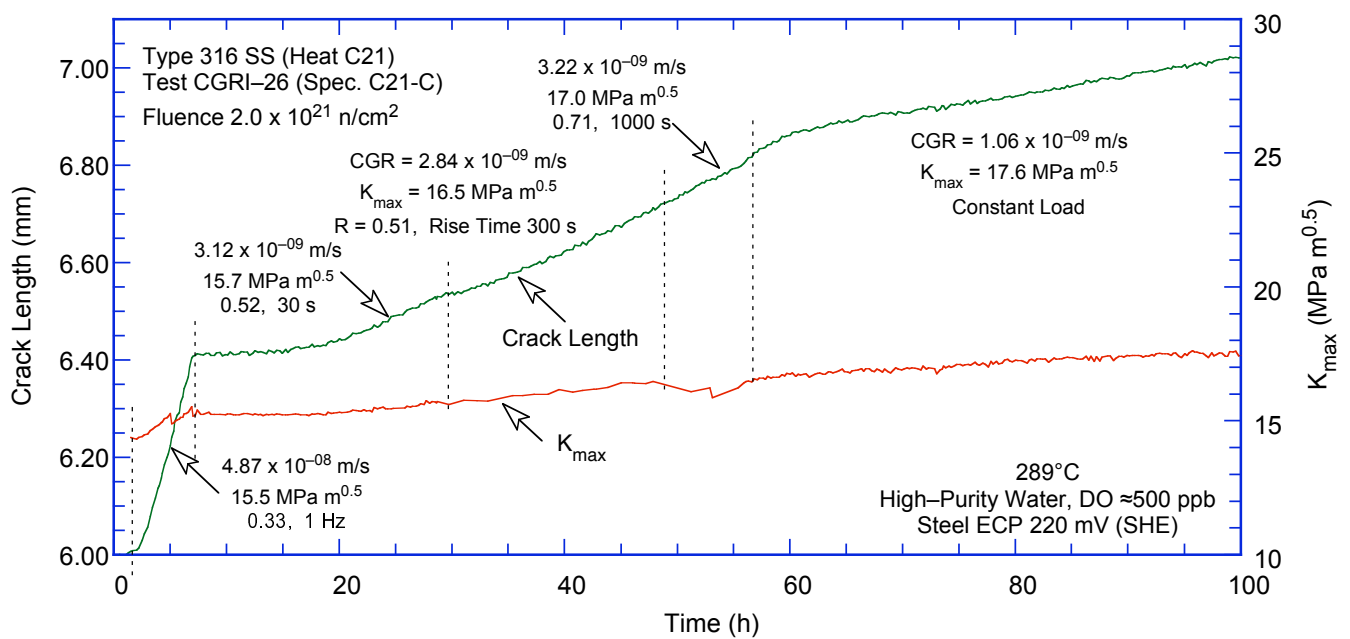

(a)

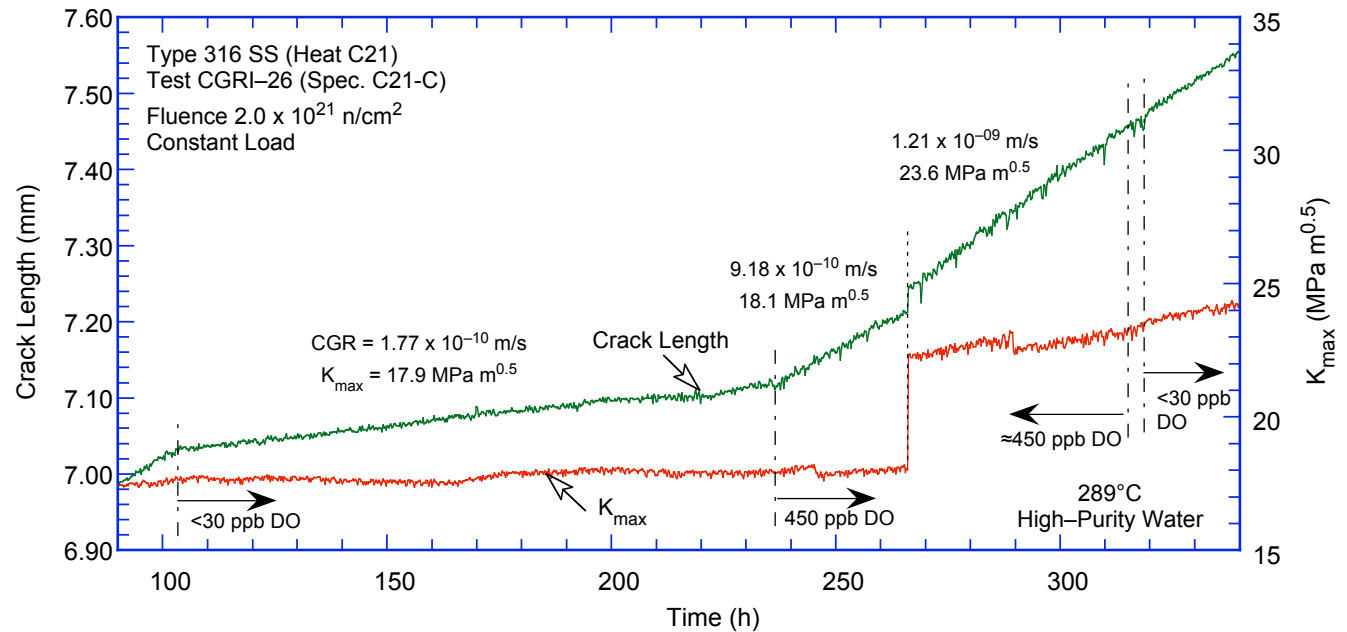

(b)

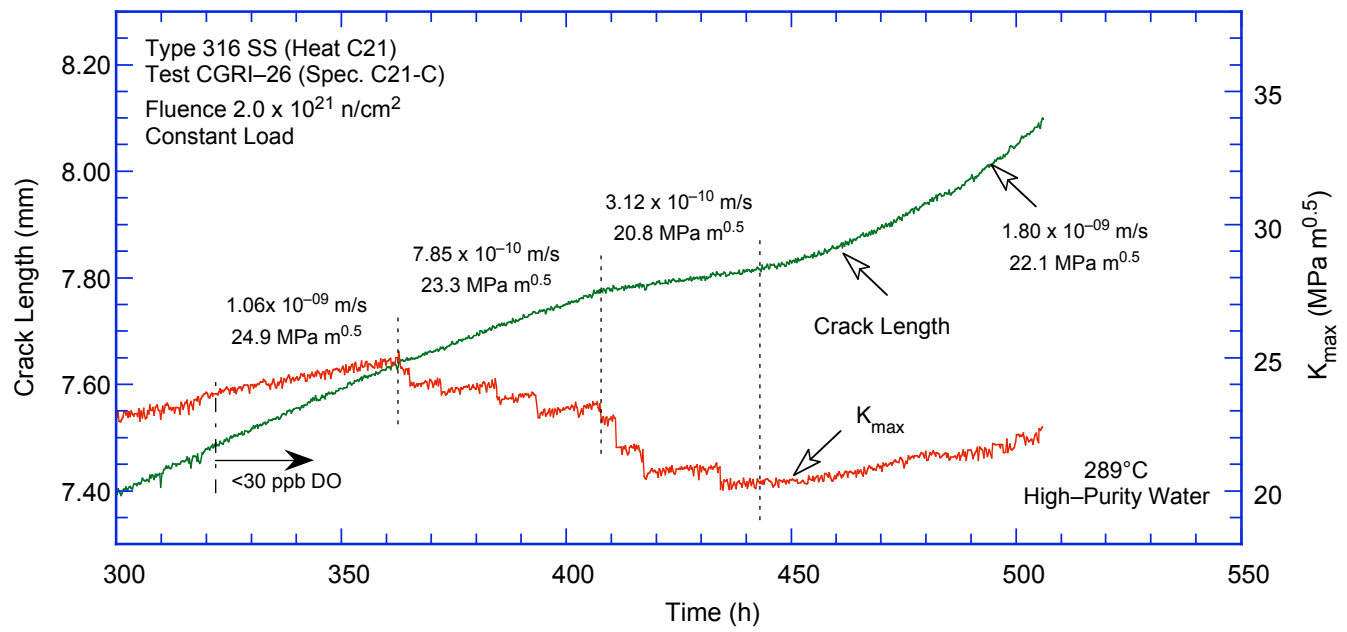

(c)

Figure 16. Crack-length-vs.-time plot for Type $316 \mathrm{SS}$ in BWR water at $288^{\circ} \mathrm{C}$ during test periods (a) precracking-3, (b) 4-7, and (c) 8-9. 


\subsubsection{Specimen 85-3TT of Sensitized Type 304 SS, Test CGRI JR-31}

The test on Specimen 85-3TT of sensitized Type 304 SS (Heat 10285) irradiated to 2.16 dpa was started in high-purity water with $300-350 \mathrm{ppb}$ DO and a flow rate of $22 \mathrm{~mL} / \mathrm{min}$. The frictional load was measured to be $\pm 156 \mathrm{~N} \mathrm{(} \pm 35 \mathrm{lb}$ ); the results presented here have been corrected to account for this frictional load. Fatigue precracking was carried out at $\mathrm{R} \approx 0.42, \mathrm{~K}_{\max } \approx 14.9 \mathrm{MPa} \mathrm{m}^{1 / 2}$, triangular waveform, and frequency of $1 \mathrm{~Hz}$. After $\approx 0.1-\mathrm{mm}$ crack extension, to transition the TG fatigue crack to an IG crack, the loading waveform was changed to a sawtooth, and the load ratio was increased to 0.7 with rise times of $30-1000 \mathrm{~s}$ and return times of 4 or $12 \mathrm{~s}$. Finally, the specimen was subjected to a constant load $\left(\mathrm{K}_{\max }=15.7 \mathrm{MPa} \mathrm{m}^{1 / 2}\right)$ to obtain the $\mathrm{SCC}$ growth rate.

After the CGR test, the DC potential measuring system was reinitialized, and a J-R test was performed on the specimen at $289^{\circ} \mathrm{C}$ in high-DO water $(\approx 350 \mathrm{ppb} \mathrm{DO})$. The test was conducted at a constant extension rate of $\approx 0.43 \mu \mathrm{m} / \mathrm{s}(0.017 \mathrm{mil} / \mathrm{s})$. The test was interrupted periodically to measure the crack length by the DC potential drop measurements. The measured load vs. extension curve and the load vs. load-line displacement curve for Specimen 85-3TT are shown in Fig 17.

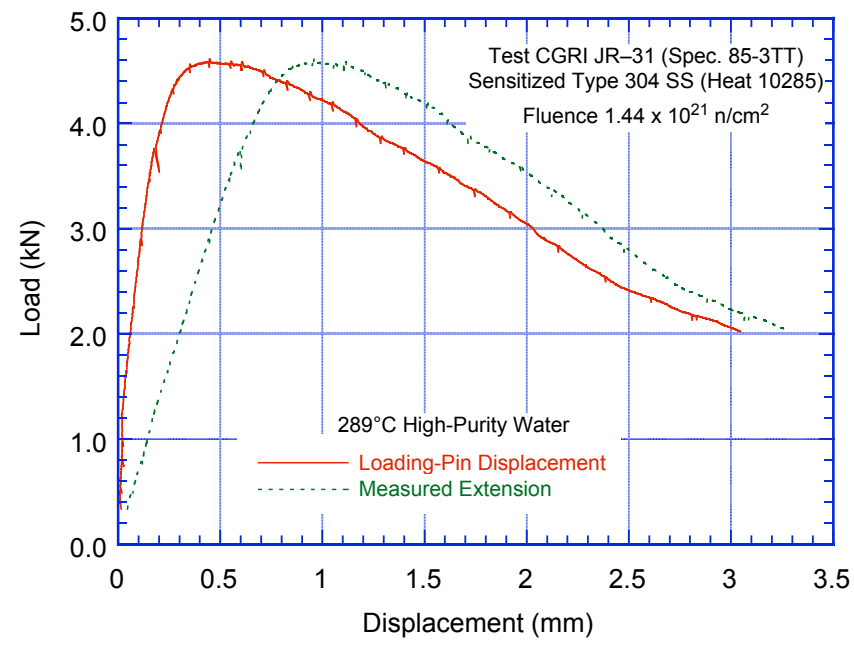

Figure 17. Load vs. load-line displacement curve for sensitized Type 304 SS tested in high-purity water at $289^{\circ} \mathrm{C}$.

The final crack size was marked by fatigue cycling at room temperature. The specimen was then fractured; a photograph of the fracture surface is shown in Fig. 18. The actual crack extension, measured from a photograph, was $\approx 28 \%$ greater than the value determined from the DC potential measurements. Crack extensions estimated from the DC potential method were adjusted accordingly. The results for the test, including the allowed $\mathrm{K}_{\max }$ from the $\mathrm{K} /$ size criterion, are given in Table 7; the changes in crack length, CGR, and $\mathrm{K}_{\max }$ with time are given in Fig. 19.

The DC potential data during the J-R curve test were also corrected to account for the effects of plasticity on the measured potential. The fracture toughness J-R curve for Specimen 85-3TT in high-DO water is shown in Fig. 20; the actual data for the J-R curve test are given in Appendix B, Table B5. The results yield a $\mathrm{J}_{\mathrm{Ic}}$ value of $176 \mathrm{~kJ} / \mathrm{m}^{2}$. 


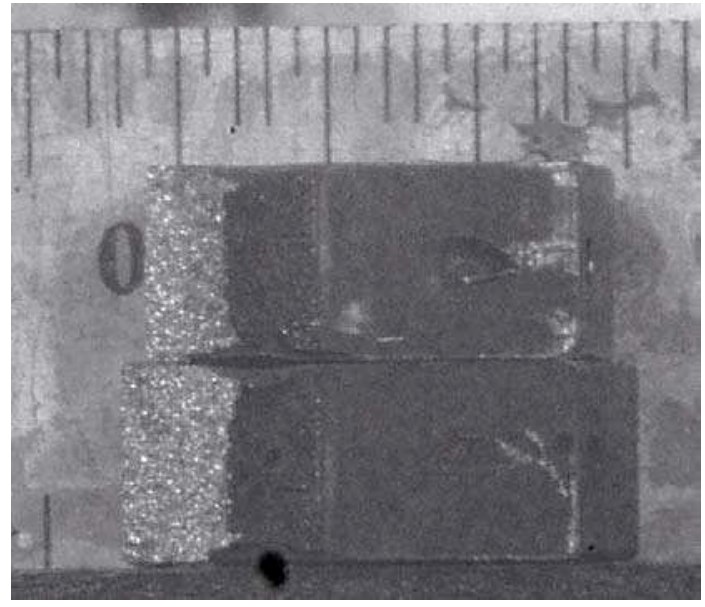

Figure 18.

Photograph of the fracture surface of for sensitized Type 304 SS tested in high-purity water at $289^{\circ} \mathrm{C}$.

Table 7. Test conditions and results for Specimen 85-3TT of sensitized Type 304 SS in high-purity water a ${ }^{\mathrm{a}}$ at $289^{\circ} \mathrm{C}$.

\begin{tabular}{|c|c|c|c|c|c|c|c|c|c|c|c|c|c|}
\hline $\begin{array}{c}\text { Test } \\
\text { Period }\end{array}$ & $\begin{array}{c}\text { Test } \\
\text { Time, } \\
\mathrm{h}\end{array}$ & $\begin{array}{c}\mathrm{E} \\
\mathrm{mV} \\
\mathrm{Pt}\end{array}$ & $\begin{array}{l}\mathrm{P}^{\mathrm{b}} \\
\text { SHE) } \\
\text { Steel }\end{array}$ & $\begin{array}{c}\mathrm{O}_{2} \\
\text { Conc., } \\
\text { ppb }\end{array}$ & $\begin{array}{c}\text { R } \\
\text { Load } \\
\text { Ratio }\end{array}$ & $\begin{array}{c}\text { Rise } \\
\text { Time, } \\
\text { s }\end{array}$ & $\begin{array}{c}\text { Return } \\
\text { Time, } \\
\text { s }\end{array}$ & $\begin{array}{c}\text { Hold } \\
\text { Time, } \\
\text { s }\end{array}$ & $\begin{array}{c}\mathrm{K}_{\max }, \\
\mathrm{MPa} \mathrm{m}^{1 / 2}\end{array}$ & $\begin{array}{c}\Delta \mathrm{K}, \\
\mathrm{MPa} \mathrm{m}^{1 / 2}\end{array}$ & $\begin{array}{c}\text { Growth } \\
\text { Rate, } \\
\mathrm{m} / \mathrm{s}\end{array}$ & $\begin{array}{c}\text { Allowed } \\
\mathrm{K}_{\max }{ }^{c} \\
\mathrm{MPa} \mathrm{m}^{1 / 2}\end{array}$ & $\begin{array}{c}\text { Crack } \\
\text { Length, }{ }^{\mathrm{d}} \\
\mathrm{mm}\end{array}$ \\
\hline & & & & & & & & & & & & & 5.812 \\
\hline Pre & 29 & - & - & 500 & 0.42 & 0.33 & 0.33 & $0.17 / 0.17$ & 14.9 & 8.7 & $1.64 \mathrm{E}-08$ & 20.4 & 5.911 \\
\hline 1 & 93 & 200 & 218 & 500 & 0.74 & 142 & 5.7 & $158 / 6.3$ & 15.3 & 4.0 & $1.02 \mathrm{E}-09$ & 20.3 & 5.986 \\
\hline 2 & 102 & 196 & e & 500 & 0.75 & 13.7 & 1.8 & $16.3 / 2.2$ & 15.4 & 3.8 & $3.16 \mathrm{E}-09$ & 20.2 & 6.027 \\
\hline 3 & 195 & $\mathrm{e}$ & $\mathrm{e}$ & 500 & 0.95 & 140 & 1.7 & $860 / 10.3$ & 15.7 & 0.7 & $2.22 \mathrm{E}-10$ & 20.1 & 6.098 \\
\hline 4 & 285 & $\mathrm{e}$ & $\mathrm{e}$ & 500 & 1.00 & - & - & - & 15.7 & - & $1.97 \mathrm{E}-10$ & 20.0 & 6.161 \\
\hline
\end{tabular}

${ }^{\mathrm{a}}$ Type $304 \mathrm{SS}$ Heat 10285 , sensitized $10.5 \mathrm{~h}$ at $600^{\circ} \mathrm{C}$, irradiated to $1.44 \times 10^{21} \mathrm{n} / \mathrm{cm}^{2}(2.16 \mathrm{dpa})$ at $\approx 297^{\circ} \mathrm{C}$.

${ }^{\mathrm{b}}$ Represents values in the effluent. Conductivity was $\approx 0.07$ and $0.3 \mu \mathrm{S} / \mathrm{cm}$ in feedwater and effluent, respectively.

${ }^{\mathrm{c}}$ Based on effective yield stress, defined as the average of irradiated and nonirradiated yield stresses.

d Actual crack extension was $28 \%$ greater than the value determined from the DC potential drop measurements.

eNot measured.

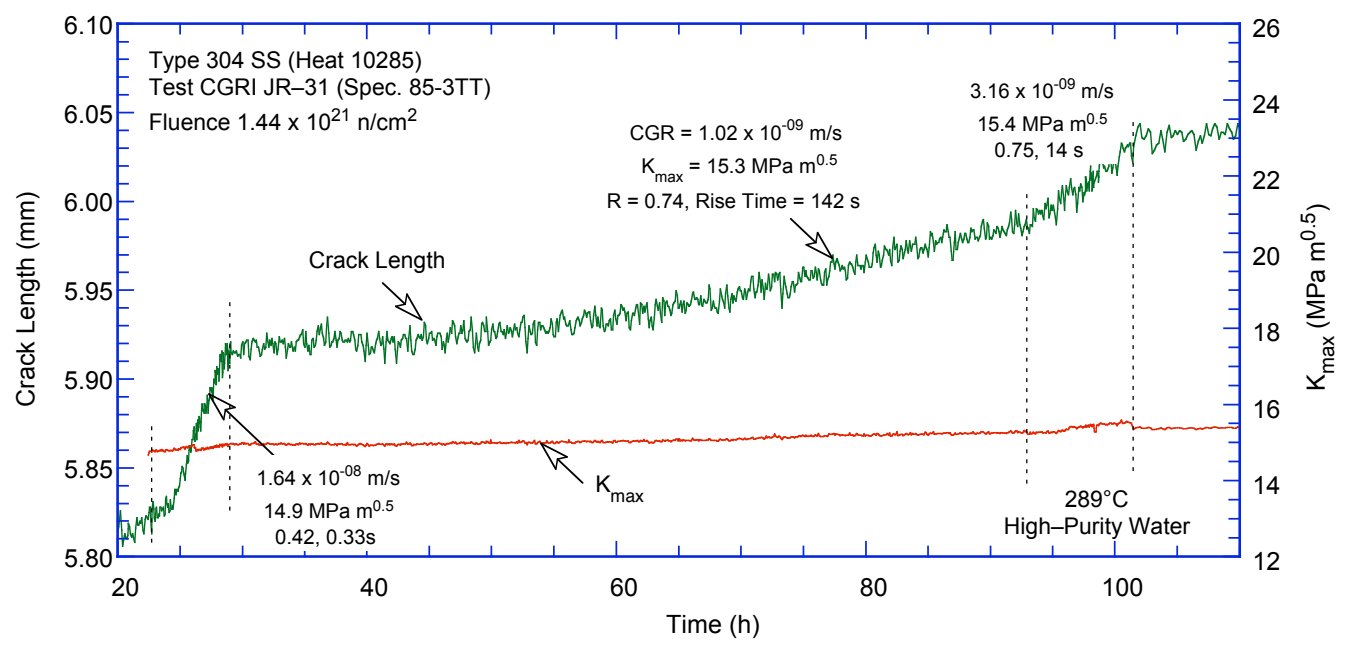

(a)

Figure 19. Crack-length-vs.-time plots for sensitized and irradiated Type 304 SS in high-purity water at $289^{\circ} \mathrm{C}$ during test periods (a) precracking-2 and (b) 3-4. 


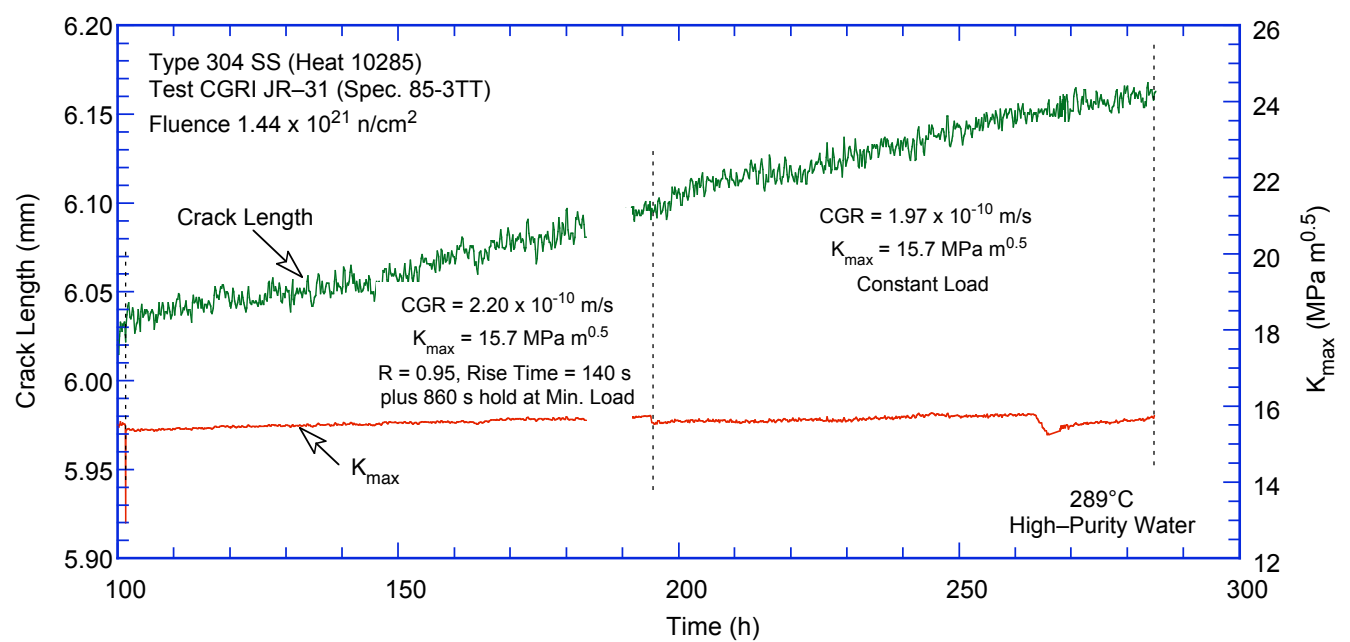

(b)

Figure 19. (Contd.)

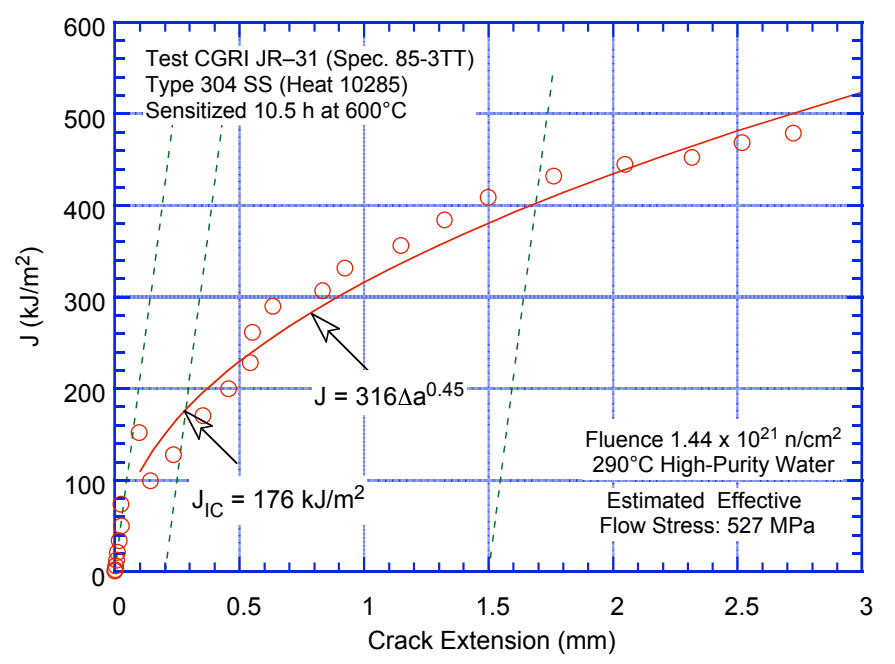

Figure 20.

Fracture toughness $\mathrm{J}-\mathrm{R}$ curve for sensitized Type 304 SS irradiated to $2.16 \mathrm{dpa}$ in high-DO water at $289^{\circ} \mathrm{C}$.

\subsection{Stainless Steel Weld HAZ Materials}

Crack growth and fracture toughness J-R curve tests have been completed in air and simulated BWR environments at $289^{\circ} \mathrm{C}$ on $1 / 4-\mathrm{T}$ CT specimens of Types 304 and 304L SS weld HAZ materials irradiated to $\approx 2.16 \mathrm{dpa}$. The significant results for the various tests are summarized below.

\subsubsection{Simulated BWR Environment}

\subsubsection{Specimen 85-XA of Type 304 SS SMA Weld HAZ, Test CGRI JR-32}

The test on Specimen 85-XA of Type 304 SS (Heat 10285) SMA weld HAZ irradiated to 2.16 dpa was started in high-purity water with $\approx 400 \mathrm{ppb} D O$ and a flow rate of $21 \mathrm{~mL} / \mathrm{min}$. The frictional load was measured to be $\pm 156 \mathrm{~N} \mathrm{(} \pm 35 \mathrm{lb}$ ); the results presented here have been corrected to account for this frictional load. Fatigue precracking was carried out at $\mathrm{R}=0.42, \mathrm{~K}_{\max }=13.3 \mathrm{MPa} \mathrm{m}{ }^{1 / 2}$, triangular waveform, and frequency of $2 \mathrm{~Hz}$. After $\approx 0.11-\mathrm{mm}$ crack extension, to transition the TG fatigue crack to an IG crack, the load ratio $\mathrm{R}$ was increased to $\approx 0.73$, and the waveform changed from triangular to 
sawtooth with rise times of 26 or $433 \mathrm{~s}$ and return times of $\approx 5 \mathrm{~s}$. Finally, the specimen was subjected to a constant load $\left(\mathrm{K}_{\max } \approx 14.0 \mathrm{MPa} \mathrm{m}^{1 / 2}\right)$ to obtain the SCC growth rate.

After the CGR test, the DC potential measuring system was reinitialized, and a J-R test was performed on the specimen at $289^{\circ} \mathrm{C}$ in high-DO water $(\approx 400 \mathrm{ppb} \mathrm{DO})$. The test was conducted at a constant extension rate of $\approx 0.43 \mu \mathrm{m} / \mathrm{s}(0.017 \mathrm{mil} / \mathrm{s})$. The test was interrupted periodically to measure crack length by the DC potential drop measurements. The measured load vs. extension curve and the load vs. load-line displacement curve for Specimen 85-XA are shown in Fig. 21.

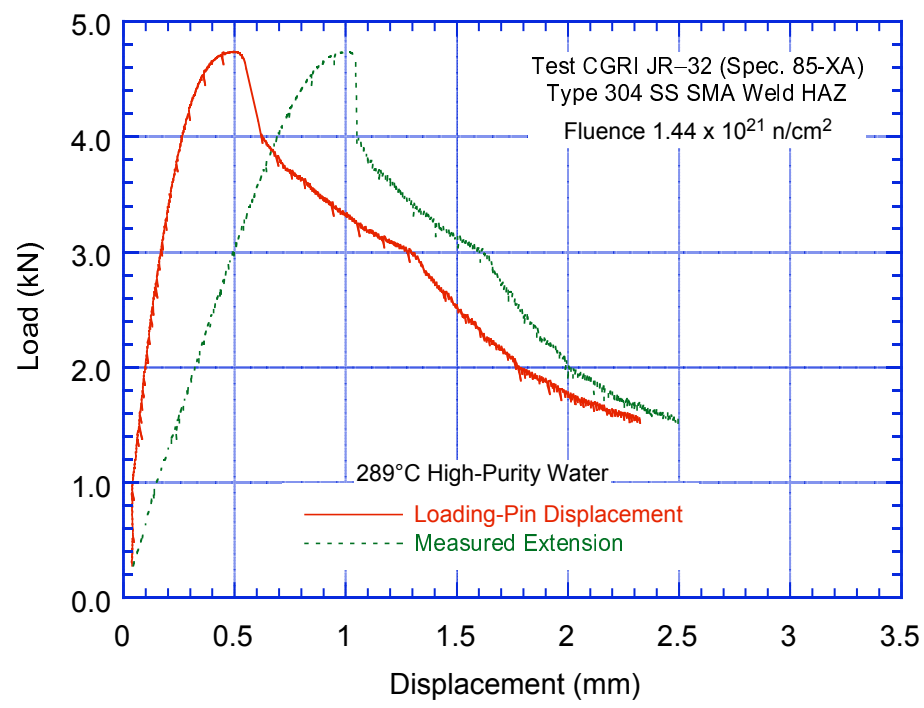

Figure 21.

Load vs. load-line displacement curve for Type 304 SS SMA weld HAZ tested in high-purity water at $289^{\circ} \mathrm{C}$.

The final crack size was marked by fatigue cycling at room temperature. The specimen was then fractured, and the final crack length of both halves of the fractured specimen was measured from the photograph of the fracture surface of Specimen 85 -XA (Fig. 22). The actual crack extension was $\approx 16 \%$ greater than the value determined from the DC potential measurements. Crack extensions estimated from the DC potential method were adjusted accordingly. The results for the CGR test, including the allowed $\mathrm{K}_{\max }$ from the $\mathrm{K} /$ size criterion, are given in Table 8; the changes in crack length, CGR, and $\mathrm{K}_{\max }$ with time are given in Fig. 23.

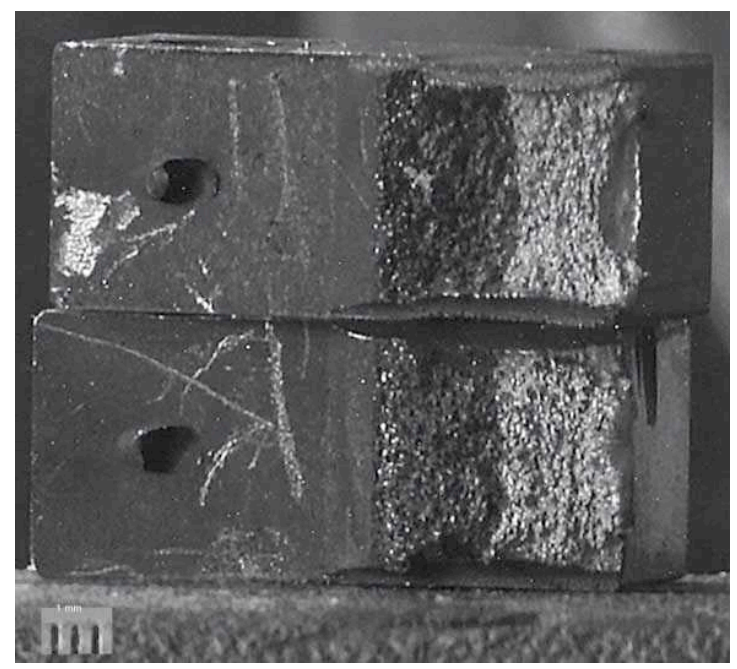

Figure 22.

Photograph of the fracture surface of Type 304 SS SMA weld HAZ tested in high-purity water at $289^{\circ} \mathrm{C}$. 
Table 8. Test conditions and results for Specimen 85-XA of Type 304 SS SMA weld HAZ in high-purity water ${ }^{\mathrm{a}}$ at $289^{\circ} \mathrm{C}$.

\begin{tabular}{|c|c|c|c|c|c|c|c|c|c|c|c|c|c|}
\hline $\begin{array}{c}\text { Test } \\
\text { Period } \\
\end{array}$ & $\begin{array}{c}\text { Test } \\
\text { Time, } \\
\mathrm{h}\end{array}$ & $\begin{array}{r}\mathrm{E} \\
\mathrm{mV} \\
\mathrm{Pt} \\
\end{array}$ & $\begin{array}{l}\mathrm{P} \\
\mathrm{P} H E) \\
\text { Steel } \\
\end{array}$ & $\begin{array}{c}\mathrm{O}_{2} \\
\text { Conc., } \\
\text { ppb }\end{array}$ & $\begin{array}{c}\mathrm{R} \\
\text { Load } \\
\text { Ratio } \\
\end{array}$ & $\begin{array}{c}\text { Rise } \\
\text { Time, } \\
\mathrm{s} \\
\end{array}$ & $\begin{array}{c}\text { Return } \\
\text { Time, } \\
\text { s } \\
\end{array}$ & $\begin{array}{c}\text { Hold } \\
\text { Time, } \\
\mathrm{s} \\
\end{array}$ & $\begin{array}{c}\mathrm{K}_{\max }, \\
\mathrm{MPa} \mathrm{m}^{1 / 2}\end{array}$ & $\begin{array}{c}\Delta \mathrm{K}, \\
\mathrm{MPa} \mathrm{m}^{1 / 2}\end{array}$ & $\begin{array}{c}\text { Growth } \\
\text { Rate, } \\
\mathrm{m} / \mathrm{s}\end{array}$ & $\begin{array}{c}\text { Allowed } \\
\mathrm{K}_{\max }{ }^{\mathrm{c}}{ }^{1 / 2} \\
\mathrm{MPa} \mathrm{m}^{1 / 2}\end{array}$ & $\begin{array}{c}\text { Crack } \\
\text { Length, } \\
\mathrm{mm}\end{array}$ \\
\hline Pre & 51 & $\mathrm{e}$ & 205 & 500 & 0.42 & 0.16 & 0.16 & $0.09 / 0.09$ & 13.3 & 7.7 & $1.86 \mathrm{E}-08$ & 20.3 & $\begin{array}{l}5.809 \\
5.920\end{array}$ \\
\hline 1 & 93 & e & 240 & 500 & 0.74 & 26 & 5.2 & $34 / 6.8$ & 13.9 & 3.6 & $2.21 \mathrm{E}-09$ & 20.2 & 6.006 \\
\hline 2 & 140 & $\mathrm{e}$ & 236 & 500 & 0.72 & 433 & 5.2 & $567 / 6.8$ & 13.0 & 3.6 & $7.07 \mathrm{E}-10$ & 20.1 & 6.061 \\
\hline 3 & 190 & $\mathrm{e}$ & 235 & 500 & 1.00 & - & - & - & 13.9 & - & $1.98 \mathrm{E}-10$ & 20.0 & 6.132 \\
\hline 4 & 331 & $\mathrm{e}$ & 210 & 500 & 1.00 & - & - & - & 14.0 & - & $2.61 \mathrm{E}-10$ & 19.8 & 6.263 \\
\hline
\end{tabular}

${ }^{a}$ Type 304 SS Heat 10285 , SMA weld HAZ irradiated to $1.44 \times 10^{21} \mathrm{n} / \mathrm{cm}^{2}(2.16 \mathrm{dpa})$ at $\approx 297^{\circ} \mathrm{C}$.

${ }^{b}$ Represents values in the effluent. Conductivity was $\approx 0.07$ and $0.3 \mu \mathrm{S} / \mathrm{cm}$ in feedwater and effluent, respectively.

${ }^{\mathrm{c}}$ Based on effective yield stress, defined as the average of irradiated and nonirradiated yield stresses.

${ }^{\mathrm{d}}$ Actual crack extension was $16 \%$ greater than the value determined from the DC potential drop measurements.

e Not measured.

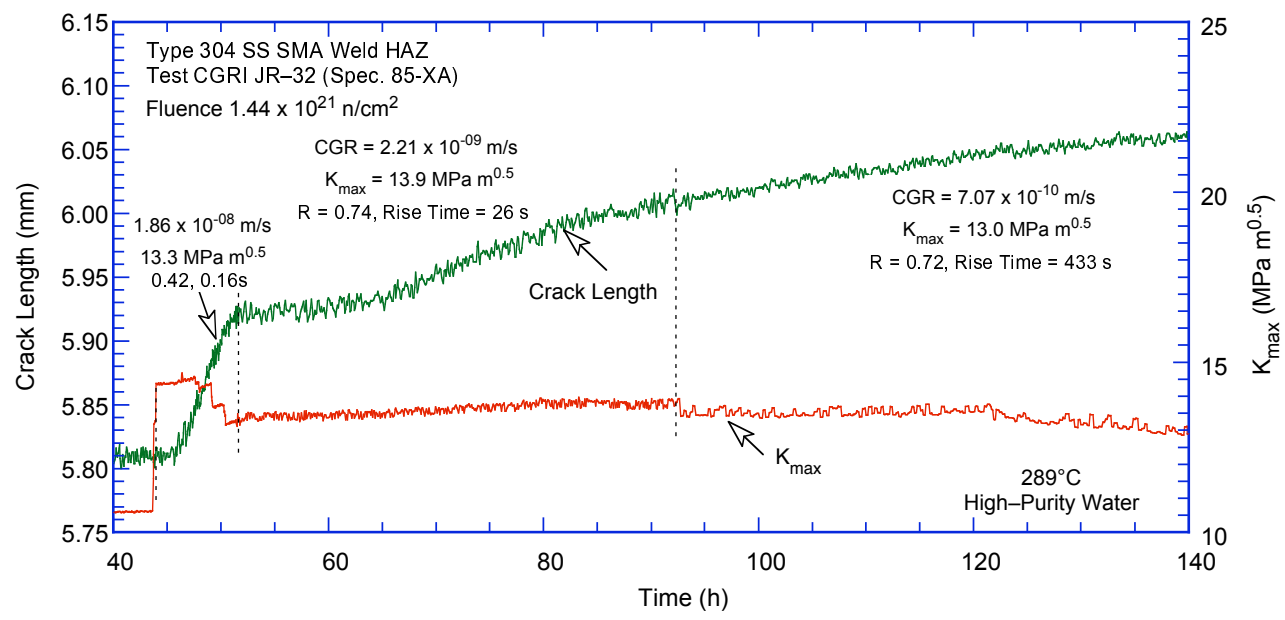

(a)

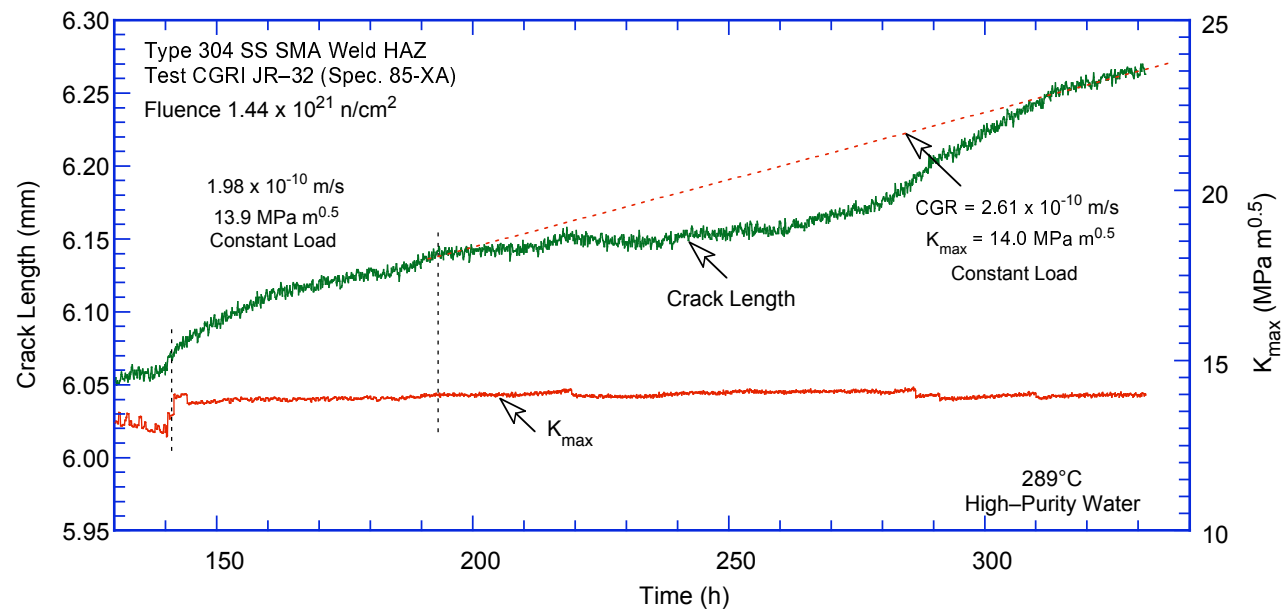

(b)

Figure 23. Crack-length-vs.-time plots for irradiated Type 304 SS SMA weld HAZ (Spec. 85-XA) in highpurity water at $289^{\circ} \mathrm{C}$ during test periods (a) precracking-2 and (b) 3-4.

The DC potential data during the J-R curve test were also corrected to account for the effects of plasticity on the measured potential. The fracture toughness J-R curve for Specimen 85-XA in high-DO 
water is shown in Fig. 24; the actual data for the J-R curve test are given in Appendix B, Table B6. The results yield a $\mathrm{J}_{\mathrm{Ic}}$ value of $128 \mathrm{~kJ} / \mathrm{m}^{2}$.

The results indicate that the fracture toughness of the SMA weld HAZ material is significantly lower than that of the sensitized material from the same heat of Type 304 SS (e.g., compare J-R curve for Specimen 85-3TT in Fig. 20). However, examination of the fracture surface through the hot cell window by telescope indicated that the fracture surface might not have been in the HAZ of the specimen. The fracture plane might have moved away from the HAZ region and into the weld metal, as indicated by Fig. 25. The sharp drop in load (Fig. 21) most likely is associated with this change in the fracture plane.

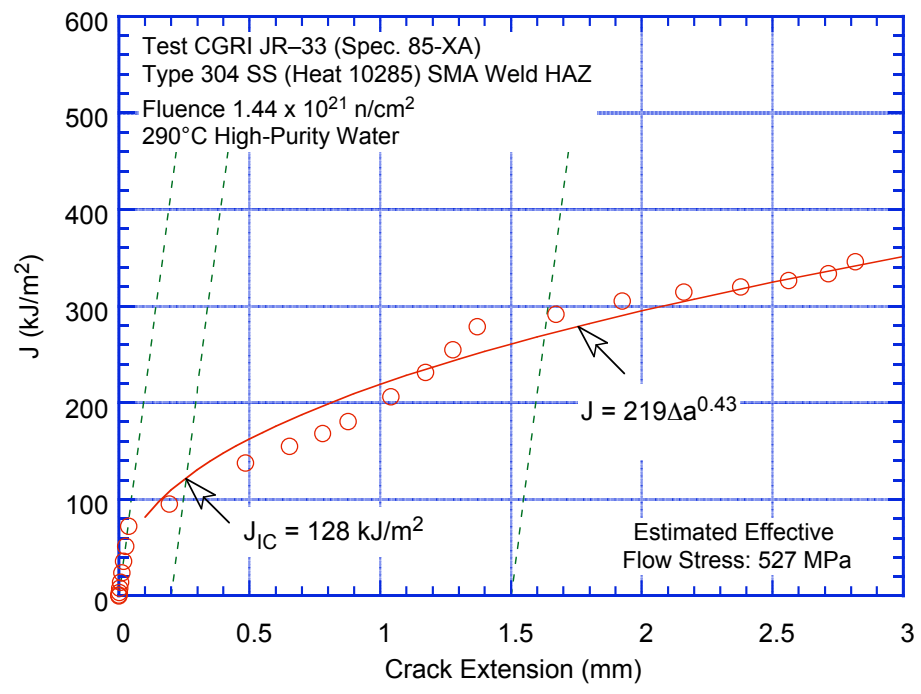

Figure 24.

Fracture toughness J-R curve for Type 304 SS SMA weld irradiated to $2.16 \mathrm{dpa}$ in high-DO water at $289^{\circ} \mathrm{C}$.
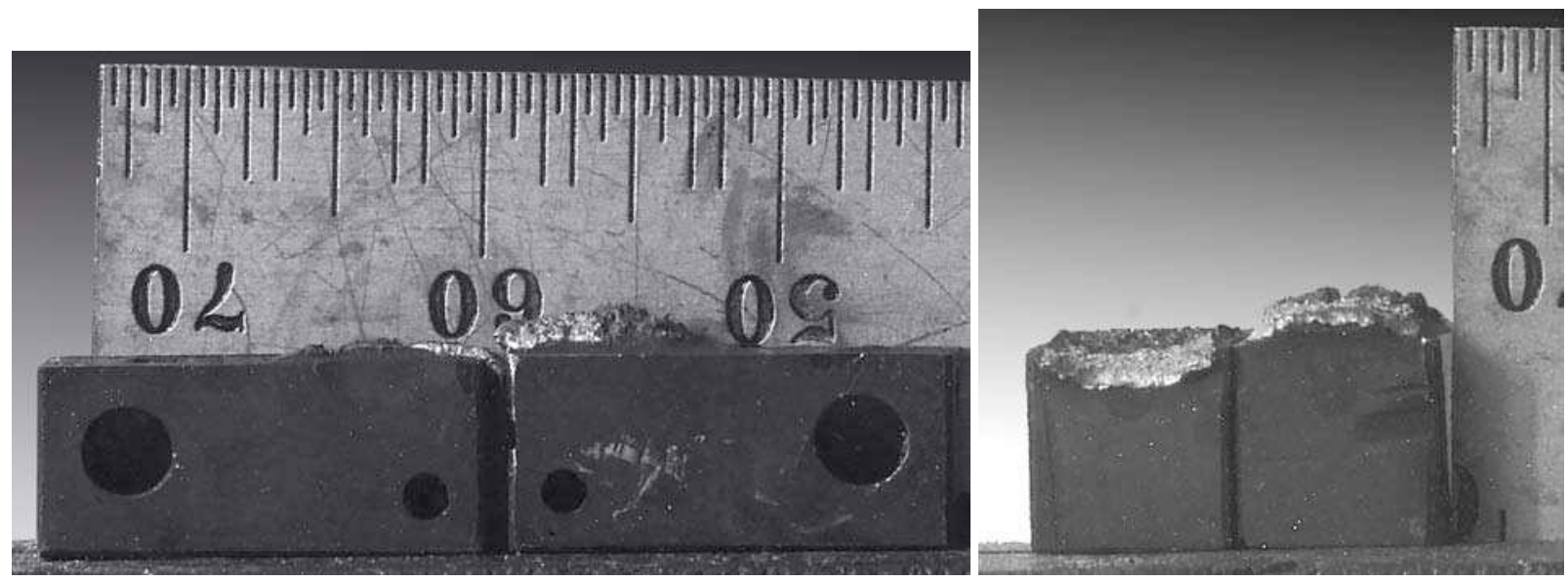

Figure 25. Fracture pieces of Type 304 SS SMA weld HAZ: (a) side view and (b) end view.

\subsubsection{Specimen GG6T-A of Type 304L SS SA Weld HAZ, Test CGRI JR-35}

The test on Specimen GG6T-A of the GG Type 304L SA weld HAZ irradiated to 2.16 dpa was started in high-purity water with $\approx 600 \mathrm{ppb} \mathrm{DO}$ and a flow rate of $20 \mathrm{~mL} / \mathrm{min}$. The measured frictional load on the pull rod was $\pm 133 \mathrm{~N}$ ( $\pm 30 \mathrm{lb}$ ) during the test; the results presented here have been corrected to account for this frictional load. Fatigue precracking was carried out at $\mathrm{R}=0.26, \mathrm{~K}_{\max } \approx 15.2 \mathrm{MPa} \mathrm{m}^{1 / 2}$, triangular waveform, and $2-\mathrm{Hz}$ frequency. After $\approx 0.26-\mathrm{mm}$ crack extension, to transition the TG fatigue crack to an IG crack, the loading waveform was changed to sawtooth with a load ratio of $\approx 0.5$, a rise time 
of $38 \mathrm{~s}$, and a return time of $2.5 \mathrm{~s}$. However, the crack actually stalled under these loading conditions, and no crack growth was observed even after $\approx 3$ days. The above steps were repeated but with one difference, the rise time was increased gradually. Environmental enhancement was achieved during test period 2. Finally, the specimen was subjected to a constant load (four conditions with decreasing load corresponding to $\mathrm{K}_{\max }=16.0,13.6,10.9$, and $7.0 \mathrm{MPa} \mathrm{m}^{1 / 2}$ ) to obtain the SCC growth rates. The CGR test was terminated after $\approx 580 \mathrm{~h}$.

After the CGR test, the DC potential measuring system was reinitialized, and a J-R test was performed on the specimen at $289^{\circ} \mathrm{C}$ in high-DO water $(\approx 600 \mathrm{ppb} \mathrm{DO})$. The test was conducted at a constant extension rate of $\approx 0.43 \mu \mathrm{m} / \mathrm{s}(0.017 \mathrm{mil} / \mathrm{s})$. The test was interrupted periodically (by holding the specimen at constant extension) to measure crack length by the DC potential drop measurements. The load vs. extension curve and the load vs. load-line displacement curve for Specimen GG6T-A are shown in Fig. 26.

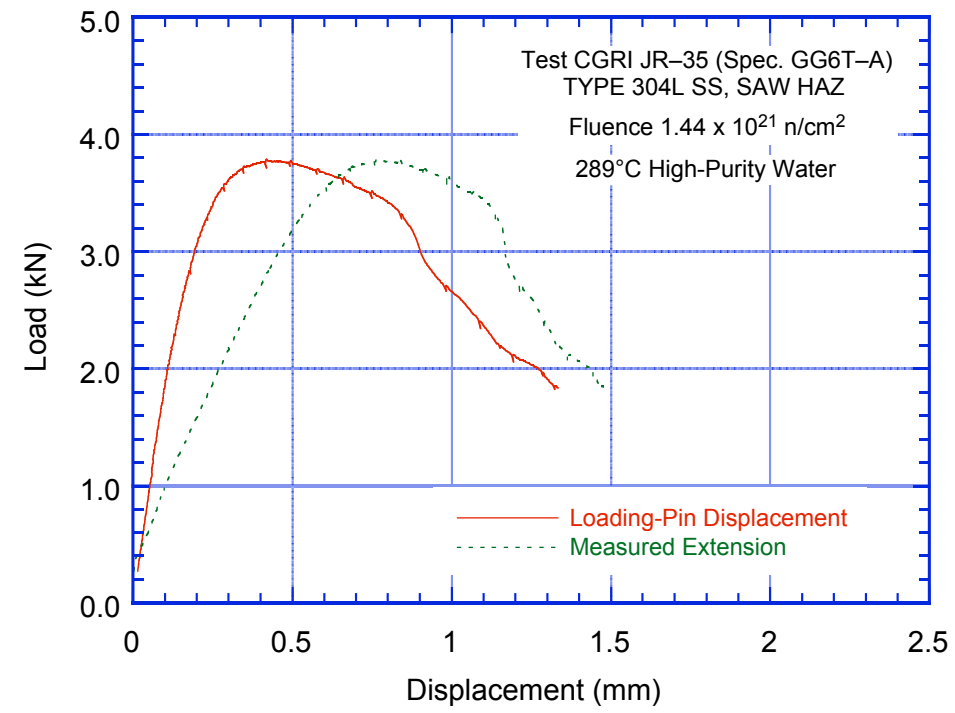

Figure 26.

Load vs. load-line displacement curve for Type 304L SS SA weld $\mathrm{HAZ}$ tested in high-purity water at $289^{\circ} \mathrm{C}$.

The final crack size was marked by fatigue cycling at room temperature. The specimen was then fractured, and the final crack length was measured from photographs of the fracture surface of both halves of the fractured specimen (Fig. 27a). The actual crack extension was $\approx 30 \%$ greater than the value determined from the DC potential measurements; the measured crack extensions were scaled proportionately. The side view of the two broken halves of the specimen, Fig. 27b, indicates a relatively straight crack plane. The results for the CGR test, including the allowed $\mathrm{K}_{\max }$ from the $\mathrm{K} /$ size criterion, are given in Table 9; the changes in crack length, CGR, and $\mathrm{K}_{\max }$ with time are given in Fig. 28. 


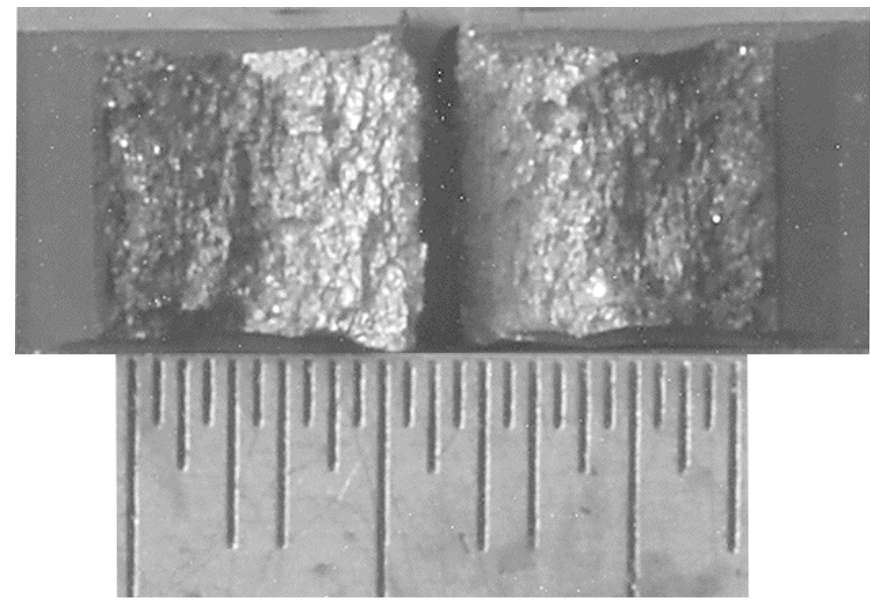

(a)

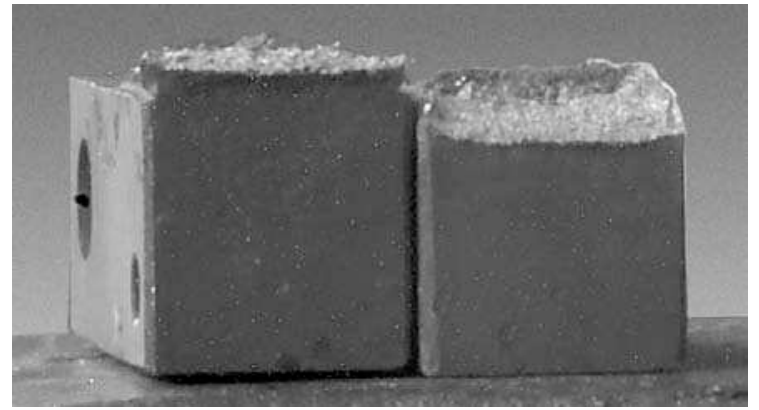

(b)

Figure 27. Photographs of the (a) fracture surface and (b) end view of Type 304L SS SA weld HAZ.

Table 9. Test conditions and results for Type 304L SS SA weld HAZ specimen GG6T-A ${ }^{a}$ in BWR water at $289^{\circ} \mathrm{C}$.

\begin{tabular}{|c|c|c|c|c|c|c|c|c|c|c|c|c|c|}
\hline $\begin{array}{c}\text { Test } \\
\text { Period }\end{array}$ & $\begin{array}{c}\text { Test } \\
\text { Time, } \\
\mathrm{h}\end{array}$ & $\begin{array}{c}\mathrm{E} \\
\mathrm{mV} \\
\mathrm{Pt} \\
\end{array}$ & $\begin{array}{l}\mathrm{b} \\
\mathrm{HE}) \\
\text { Steel }\end{array}$ & $\begin{array}{c}\mathrm{O}_{2} \\
\text { Conc., } \\
\text { ppb }\end{array}$ & $\begin{array}{c}\mathrm{R} \\
\text { Load } \\
\text { Ratio } \\
\end{array}$ & $\begin{array}{c}\text { Rise } \\
\text { Time, } \\
\mathrm{s}\end{array}$ & $\begin{array}{l}\text { Return } \\
\text { Time, } \\
\text { s }\end{array}$ & $\begin{array}{l}\text { Hold } \\
\text { Time, }{ }^{c} \\
\text { s }\end{array}$ & $\begin{array}{c}\mathrm{K}_{\max } \\
\mathrm{MPa} \mathrm{m}^{1 / 2}\end{array}$ & $\begin{array}{c}\Delta \mathrm{K}, \\
\mathrm{MPa} \mathrm{m}^{1 / 2}\end{array}$ & $\begin{array}{c}\text { Growth } \\
\text { Rate, } \\
\mathrm{m} / \mathrm{s}\end{array}$ & $\begin{array}{c}\text { Allowed } \\
\mathrm{K}_{\max }{ }{ }^{1 / 2} \\
\mathrm{MPa} \mathrm{m}^{1 / 2}\end{array}$ & $\begin{array}{c}\text { Crack } \\
\text { Length, } \\
\text { mm }\end{array}$ \\
\hline & & & & & & & & & & & & & 5.827 \\
\hline Pre & 8 & 233 & 232 & 600 & 0.26 & 0.18 & 0.18 & $0.07 / 0.07$ & 15.2 & 11.3 & $4.54 \mathrm{E}-08$ & 20.8 & 6.179 \\
\hline $1 \mathrm{a}$ & 71 & 229 & 230 & 600 & 0.53 & 38 & 2.5 & $22 / 1.5$ & 15.0 & 7.1 & no growth & 20.8 & 6.178 \\
\hline $1 b$ & 79 & 228 & 229 & 600 & 0.29 & 0.18 & 0.18 & $0.07 / 0.07$ & 15.3 & 11.0 & $5.93 \mathrm{E}-10$ & 20.8 & 6.185 \\
\hline $1 \mathrm{c}$ & 101 & 224 & 223 & 600 & 0.29 & 7.3 & 7.3 & $2.7 / 2.7$ & 15.5 & 11.0 & $3.91 \mathrm{E}-10$ & 20.7 & 6.194 \\
\hline 2 & 127 & 222 & 223 & 600 & 0.57 & 7.4 & 2.5 & $4.6 / 1.5$ & 15.4 & 6.6 & $1.44 \mathrm{E}-09$ & 20.6 & 6.249 \\
\hline 3 & 151 & 221 & 222 & 600 & 0.57 & 37 & 2.5 & $23 / 1.5$ & 15.4 & 6.6 & $6.29 \mathrm{E}-10$ & 20.6 & 6.279 \\
\hline 4 & 195 & 219 & 220 & 600 & 0.67 & 168 & 6.7 & $132 / 5.3$ & 16.2 & 5.4 & $7.85 \mathrm{E}-10$ & 20.5 & 6.345 \\
\hline 5 & 238 & 221 & 222 & 600 & 0.67 & 559 & 6.7 & $441 / 5.3$ & 16.1 & 5.4 & $6.08 \mathrm{E}-10$ & 20.4 & 6.398 \\
\hline 6 & 288 & 222 & 223 & 600 & 1.00 & - & - & - & 16.0 & - & $4.17 \mathrm{E}-10$ & 20.2 & 6.482 \\
\hline 7 & 412 & 223 & 224 & 600 & 1.00 & - & - & - & 13.6 & - & $4.04 \mathrm{E}-10$ & 20.0 & 6.595 \\
\hline 8 & 507 & 217 & 218 & 600 & 1.00 & - & - & - & 10.9 & - & $5.78 \mathrm{E}-10$ & 19.8 & 6.711 \\
\hline 9 & 575 & 217 & 218 & 600 & 1.00 & - & - & - & 7.0 & - & $1.66 \mathrm{E}-10$ & 19.7 & 6.747 \\
\hline
\end{tabular}

${ }^{\mathrm{a}}$ Grand Gulf Type 304L SS core shroud shell, SA weld HAZ irradiated to $1.44 \times 10^{21} \mathrm{n} / \mathrm{cm}^{2}(2.16 \mathrm{dpa})$ at $\approx 297^{\circ} \mathrm{C}$.

${ }^{b}$ Represents values in the effluent. Conductivity and DO were $\approx 0.07 \mu \mathrm{S} / \mathrm{cm}$ and $800 \mathrm{ppb}$, respectively, in the feedwater.

${ }^{\mathrm{c}}$ Hold periods at maximum load during the unloading cycle and at minimum load during the loading cycle.

${ }^{\mathrm{d}}$ Based on effective yield stress, defined as the average of irradiated and nonirradiated yield stresses.

${ }^{\mathrm{e}}$ Actual crack extension was $30 \%$ greater than the value determined from the DC potential drop measurements.

The DC potential data during the J-R curve test were also corrected to account for the effects of plasticity on the measured potential. The fracture toughness J-R curve for Specimen GG6T-A in high-DO water is shown in Fig. 29; the actual data for the J-R curve test are given in Appendix B, Table B7. The results yield a $\mathrm{J}_{\mathrm{Ic}}$ value of $121 \mathrm{~kJ} / \mathrm{m}^{2}$. 


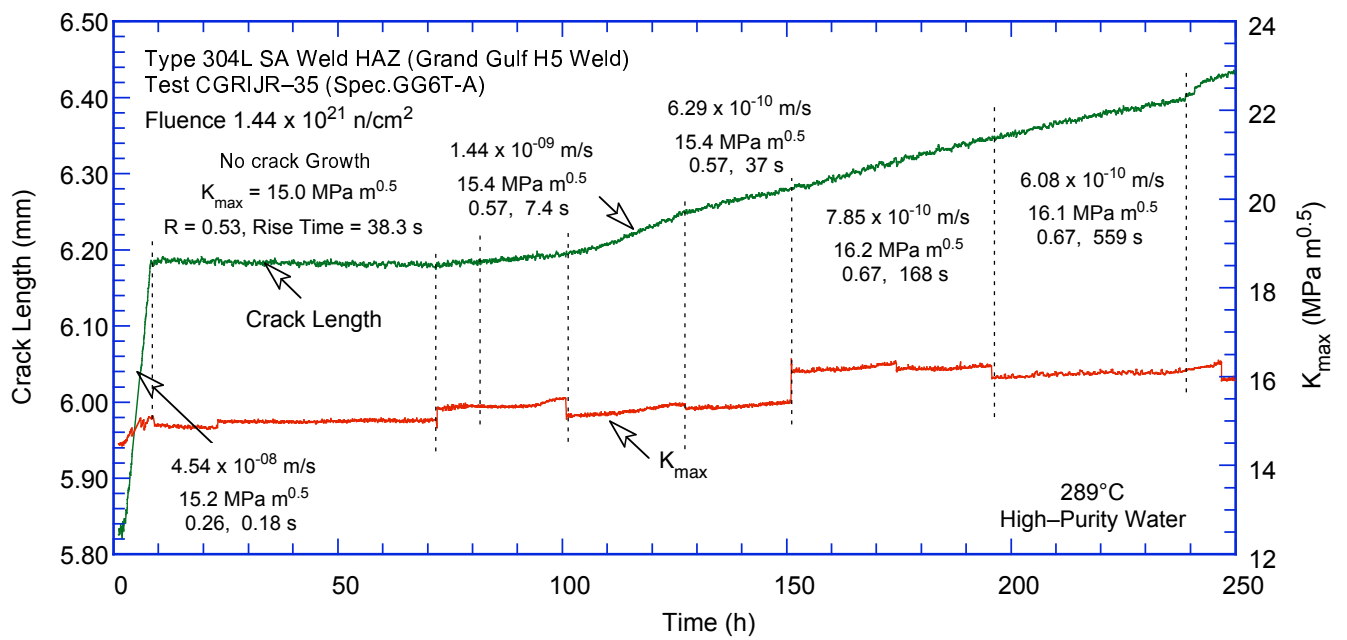

(a)

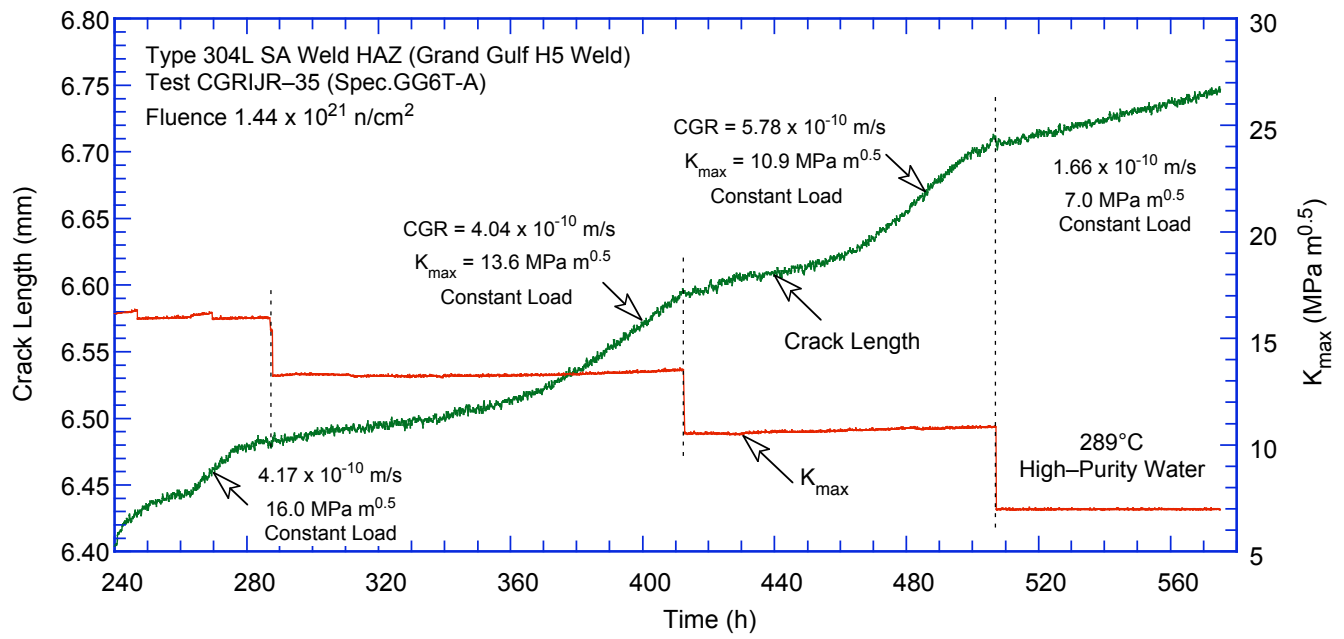

(b)

Figure 28. Crack-length-vs.-time plot for Type 304L SS SA weld HAZ in BWR water at $289^{\circ} \mathrm{C}$ for test periods (a) precracking-5 and (b) 6-9.

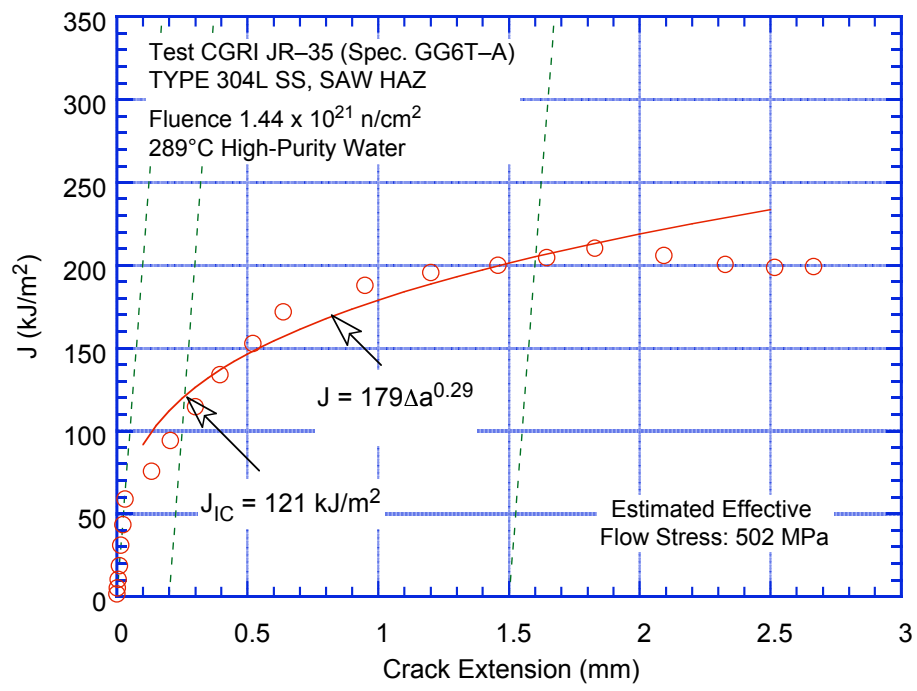

Figure 29.

Fracture toughness J-R curve for Type 304L SS SA weld HAZ material in high-DO water at $289^{\circ} \mathrm{C}$. 


\subsubsection{Air Environment}

\subsubsection{Specimen 85-XB of Type 304 SS SMA Weld HAZ, Test JRI-35}

The test on Specimen 85-XB of Type 304 SS SMA weld HAZ irradiated to 2.16 dpa was initiated by fatigue precracking the specimen at $\mathrm{R}=0.28, \mathrm{~K}_{\max } \approx 20.2 \mathrm{MPa} \mathrm{m}^{1 / 2}$, triangular waveform, and $2-\mathrm{Hz}$ frequency in air at $289^{\circ} \mathrm{C}$. As discussed in Section 2.3.1, because the autoclave, including the Bal-seal, was used as the test chamber for tests in air, the experimental data in air were also corrected for the frictional load between the pull rod and the Bal-seal. For this test, the frictional load was measured to be $\pm 133 \mathrm{~N}( \pm 30 \mathrm{lb}$ ); the results presented here have been corrected to account for this frictional load. After $\approx 0.31$-mm crack advance, the waveform was changed to a slow/fast sawtooth, and CGRs were obtained at $\mathrm{R}=0.3-0.5$ and rise times $=5-50 \mathrm{~s}$.

Fatigue loading was stopped after $\approx 0.7$-mm crack extension, and a fracture toughness $\mathrm{J}$-R curve test was performed on the specimen in air at $289^{\circ} \mathrm{C}$. The test, conducted at a constant extension rate of $\approx 0.43 \mu \mathrm{m} / \mathrm{s}(0.017 \mathrm{mil} / \mathrm{s})$, was interrupted periodically (by holding the specimen at constant extension) to measure crack length by the DC potential drop measurements. Unfortunately, a complete J-R curve could not be obtained for the specimen because of a large abrupt load drop (from 5.4 to $<1.0 \mathrm{kN}$ ) at $\approx 0.5-\mathrm{mm}$ load-line displacement. The crack advanced more than $3 \mathrm{~mm}$ during the load drop; the test was terminated. A sharp load drop, near the onset of crack extension, also occurred for a duplicate specimen of the same material tested in NWC BWR water. However, the crack extension was only $\approx 0.3 \mathrm{~mm}$, and a stable crack extension was observed for the remainder of that test. The load vs. extension curve and the load vs. load-line displacement curve for Specimen 85-XB are shown in Fig. 30.

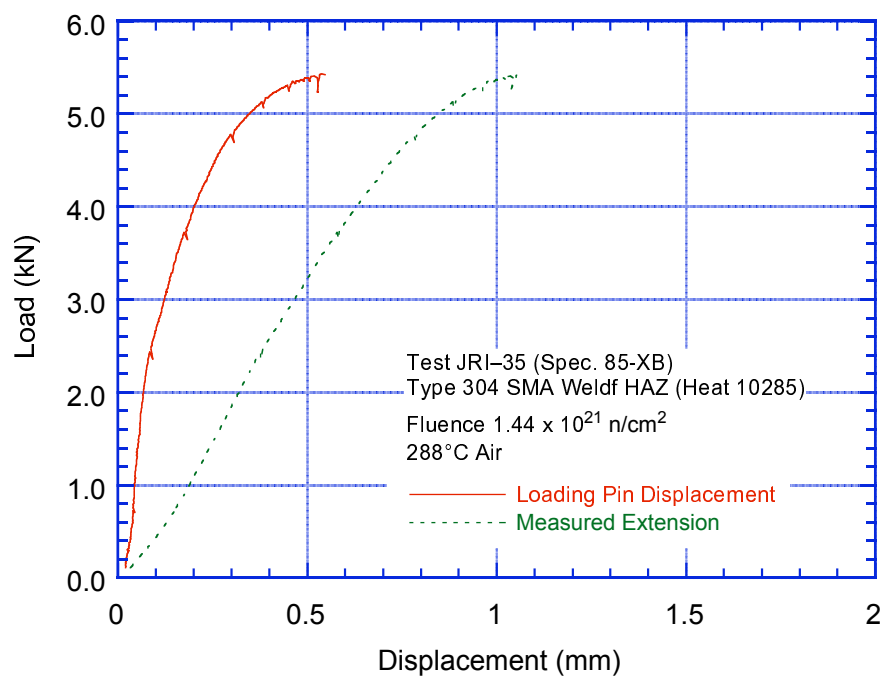

Figure 30 .

Load vs. load-line displacement curve for Type 304 SS SMA weld $\mathrm{HAZ}$ tested in air at $289^{\circ} \mathrm{C}$.

The specimen was then broken open, and crack extension during the CGR test and final crack length were measured from photographs of the fracture surface of the two broken halves (Fig. 31). The actual fatigue crack length was $25 \%$ greater than the values determined from the DC potential measurements; the measured crack extensions were scaled proportionately. The results for the CGR test, including the allowed $\mathrm{K}_{\max }$ from the $\mathrm{K} /$ size criterion, are given in Table 10; the changes in crack length, $\mathrm{CGR}$, and $\mathrm{K}_{\max }$ with time are given in Fig. 32.

The side and end views of the two broken halves of the specimen are shown in Figs. 33 and 34, respectively. These photographs indicate that crack extension was along the normal plane during the 


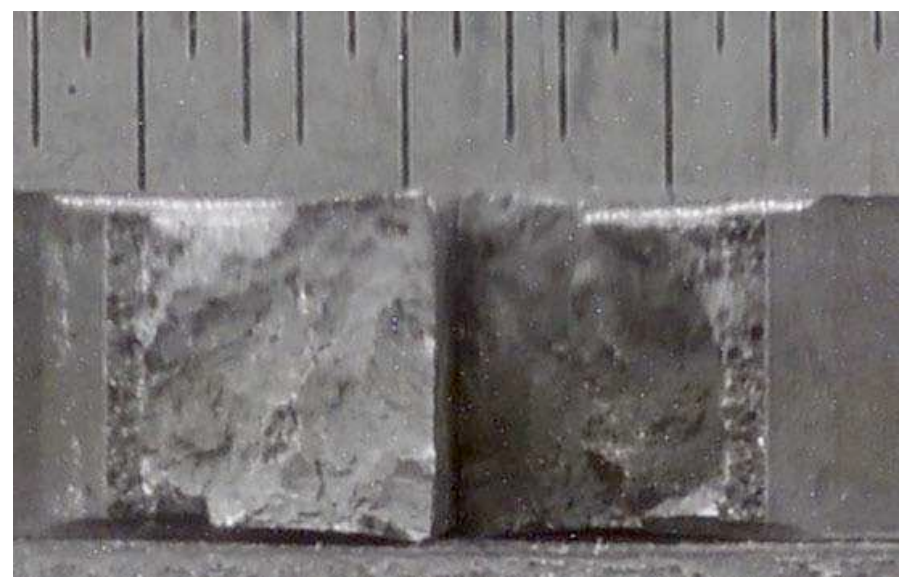

Figure 31.

Photograph of the fracture surface of the two halves of Type 304 SS SMA weld HAZ.

Table 10. Test conditions and results for Type 304 SMA weld HAZ specimen $85-\mathrm{XB}^{\mathrm{a}}$ in air at $289^{\circ} \mathrm{C}$.

\begin{tabular}{|c|c|c|c|c|c|c|c|c|c|c|c|}
\hline $\begin{array}{c}\text { Test } \\
\text { Period } \\
\end{array}$ & $\begin{array}{c}\text { Test } \\
\text { Time, } \\
\mathrm{h} \\
\end{array}$ & $\begin{array}{c}\mathrm{R} \\
\text { Load } \\
\text { Ratio } \\
\end{array}$ & $\begin{array}{c}\text { Rise } \\
\text { Time, } \\
\mathrm{s} \\
\end{array}$ & $\begin{array}{c}\text { Return } \\
\text { Time, } \\
\mathrm{s} \\
\end{array}$ & $\begin{array}{c}\text { Hold } \\
\text { Time, }^{b} \\
\text { s } \\
\end{array}$ & $\begin{array}{c}\mathrm{K}_{\max }, \\
\mathrm{MPa} \mathrm{m}^{1 / 2}\end{array}$ & $\begin{array}{c}\Delta \mathrm{K}, \\
\mathrm{MPa} \mathrm{m}^{1 / 2}\end{array}$ & $\begin{array}{c}\text { Growth } \\
\text { Rate, } \\
\mathrm{m} / \mathrm{s} \\
\end{array}$ & $\begin{array}{c}\text { Allowed } \\
\mathrm{K}_{\max }, \\
\mathrm{MPa} \mathrm{m}^{1 / 2}\end{array}$ & $\begin{array}{c}\mathrm{K}_{\max }- \\
\mathrm{K}_{\text {allowed }}{ }^{\circ} \\
\%\end{array}$ & $\begin{array}{c}\text { Crack } \\
\text { Length }^{\mathrm{d}} \\
\mathrm{mm} \\
\end{array}$ \\
\hline & & & & & & & & & & & 5.747 \\
\hline Pre & 3 & 0.28 & 0.20 & 0.20 & $0.05 / 0.05$ & 20.2 & 14.6 & $8.15 \mathrm{E}-08$ & 20.0 & 1 & 6.064 \\
\hline $1 \mathrm{c}$ & 23 & 0.55 & 40.8 & 8.2 & $19.2 / 3.8$ & 18.7 & 8.5 & $2.23 \mathrm{E}-10$ & 20.0 & -6 & 6.094 \\
\hline 2 & 47 & 0.44 & 4.4 & 0.72 & $1.6 / 0.28$ & 19.8 & 11.0 & 2.83E-09 & 19.7 & 0 & 6.254 \\
\hline 3 & 120 & 0.43 & 43.5 & 2.9 & $16.5 / 1.1$ & 19.8 & 11.3 & $4.23 \mathrm{E}-10$ & 19.6 & 1 & 6.338 \\
\hline 4 & 143 & 0.39 & 8.8 & 2.9 & $3.2 / 1.1$ & 19.8 & 12.1 & $2.60 \mathrm{E}-09$ & 19.4 & 2 & 6.442 \\
\hline
\end{tabular}

aType 304 SS Heat 10285 , SMA weld HAZ irradiated to $1.44 \times 10^{21} \mathrm{n} / \mathrm{cm}^{2}(2.16 \mathrm{dpa})$ at $\approx 297^{\circ} \mathrm{C}$.

${ }^{b}$ Hold periods at maximum load during the unloading cycle and at minimum load during the loading cycle.

${ }^{\mathrm{c}}$ Based on effective yield stress, defined as the average of irradiated and nonirradiated yield stresses.

${ }^{d}$ Actual crack extension was $25 \%$ greater than the value determined from the DC potential drop measurements.

fatigue crack growth test, but the abrupt 3-mm crack extension during the J-R curve test occurred away from the normal plane, particularly near the specimen sides. It is not clear whether the crack extended into the weld metal or base metal. Also, because the crack plane moved considerably away from the normal plane and away from the side groove, the specimen fractured along a plane nearly $2 \mathrm{~mm}$ away from the side groove.

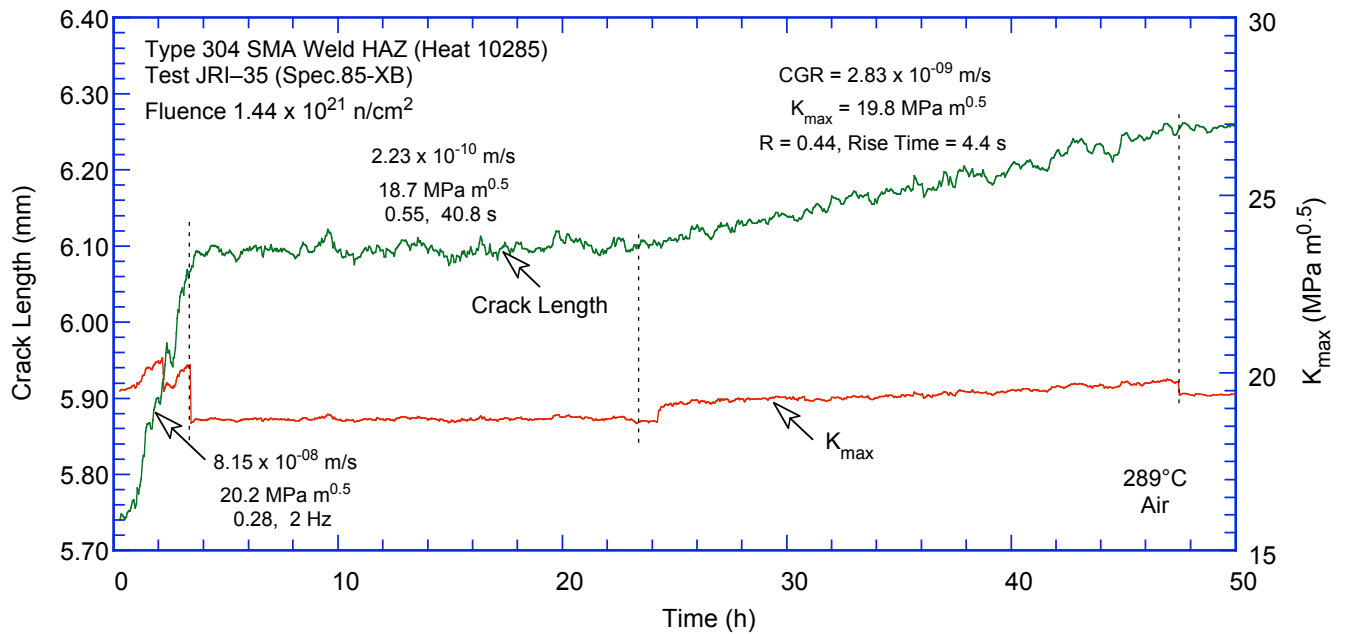

(a)

Figure 32. Crack-length-vs.-time plots for irradiated Type 304 SS SMA weld HAZ (Spec. 85-XB) in air at $289^{\circ} \mathrm{C}$ during test periods (a) precracking-2 and (b) 3-4. 


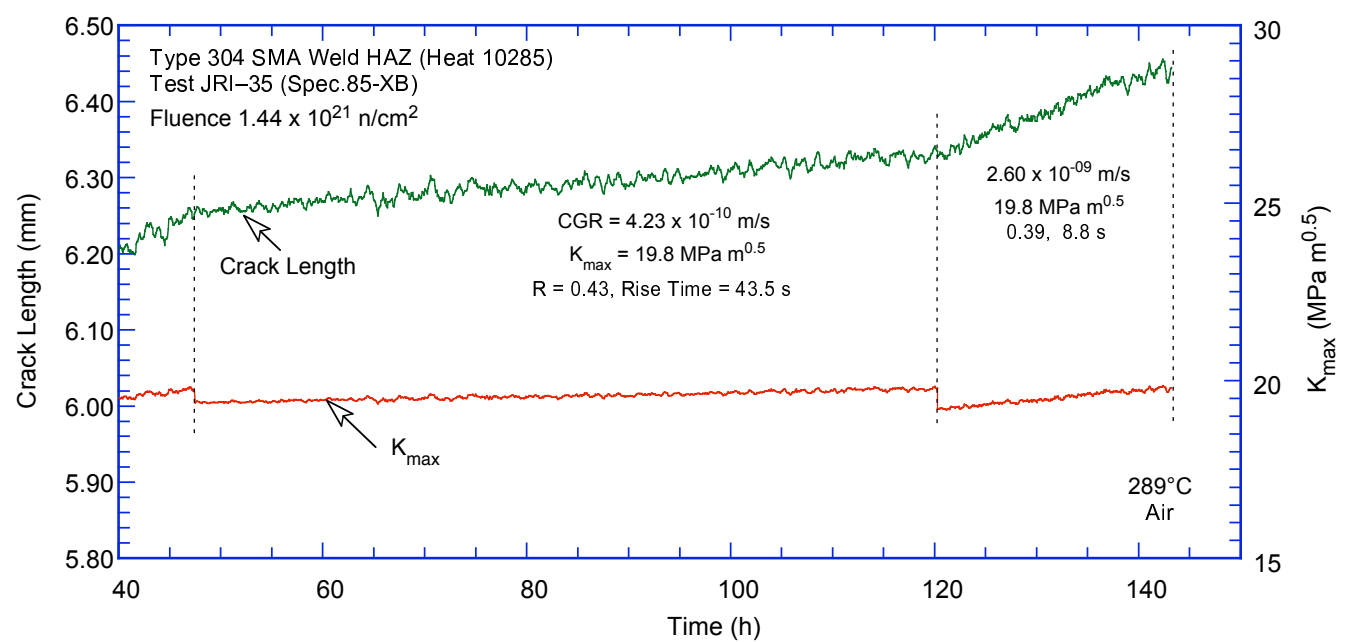

(b)

Figure 32. (Contd.)

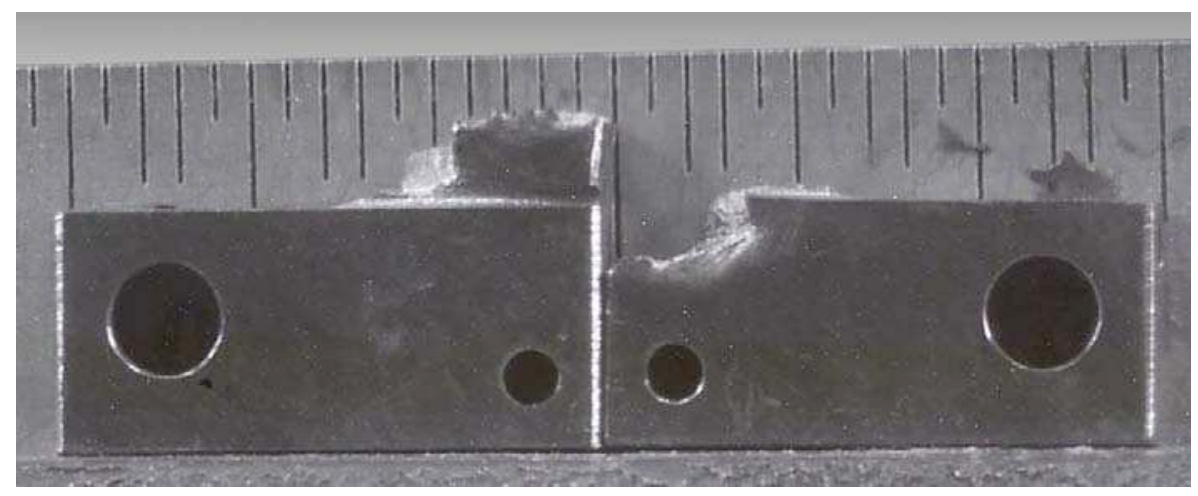

Figure 33.

Photograph of the side view of the two halves of Type 304 SS SMA weld HAZ.

The DC potential data during the J-R curve test were corrected to account for the effects of plasticity on the measured potential. The fracture toughness J-R curve for Specimen $85-\mathrm{XB}$ in air is shown in Fig. 35; the actual data for the J-R curve test are given in Appendix B, Table B8. The J-R curve for a duplicate specimen of the same material (Specimen 85-XA) tested in the NWC BWR environment is also included in the figure for comparison. The limited data in air suggest that the fracture toughness J-R curve for this material may not be significantly different from that in NWC BWR water.

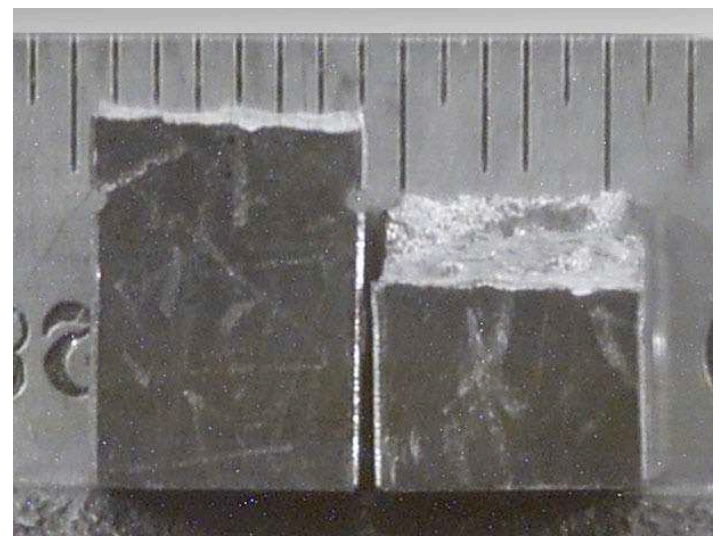

Figure 34 .

Photograph of the end view of the two halves of Type 304 SS SMA weld HAZ. 


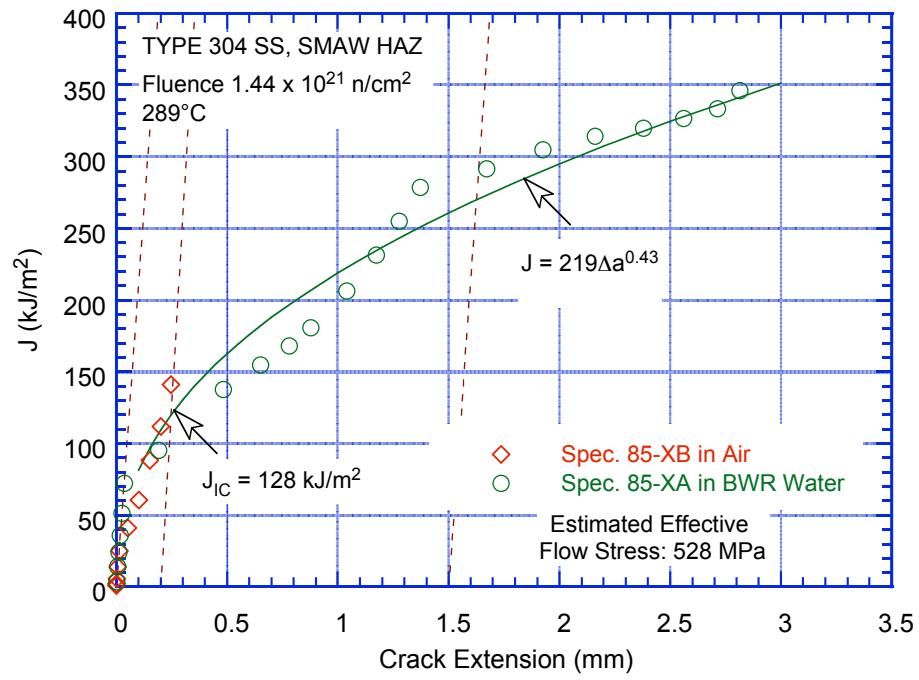

Figure 35.

Fracture toughness $\mathrm{J}-\mathrm{R}$ curve for Type 304 SS SMA weld HAZ irradiated to 2.16 dpa tested in air and NWC BWR water at $289^{\circ} \mathrm{C}$.

\subsubsection{Specimen GG6T-B of Type 304L SS SA Weld HAZ, Test JRI-36}

The test on Specimen GG6T-B of Type 304L SS SA weld HAZ irradiated to 2.16 dpa was initiated by fatigue precracking the specimen at $\mathrm{R}=0.20, \mathrm{~K}_{\max } \approx 17.6 \mathrm{MPa}^{1 / 2}$, triangular waveform, and $2-\mathrm{Hz}$ frequency in air at $289^{\circ} \mathrm{C}$. The frictional load in the system was measured to be $\pm 102 \mathrm{~N}( \pm 23 \mathrm{lb})$; the results presented here have been corrected to account for this frictional load. After $\approx 0.43$-mm crack advance, the waveform was changed to a slow/fast sawtooth, and CGRs were obtained at $\mathrm{R} \approx 0.35$ and rise times $=23$ or $5 \mathrm{~s}$.

Fatigue loading was stopped after $\approx 0.6$-mm crack extension, and a fracture toughness J-R curve test was performed on the specimen in air at $289^{\circ} \mathrm{C}$. The test, conducted at a constant extension rate of $\approx 0.43 \mu \mathrm{m} / \mathrm{s}(0.017 \mathrm{mil} / \mathrm{s})$, was interrupted periodically (by holding the specimen at constant extension) to measure crack length by the DC potential drop measurements. The load vs. extension curve and the load vs. load-line displacement curve for Specimen 85-XB are shown in Fig. 36.

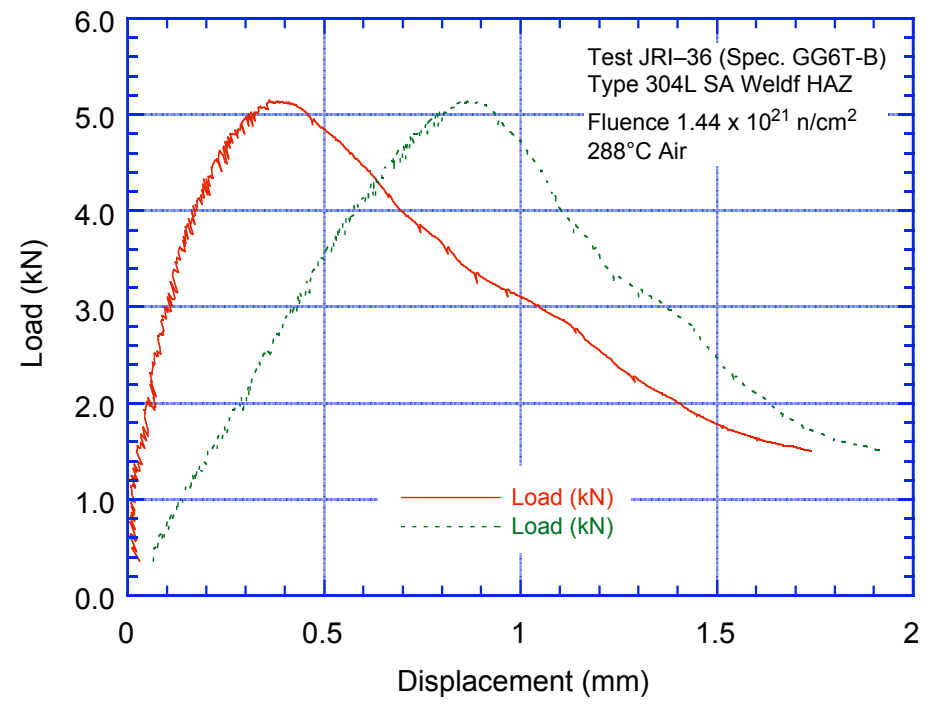

Figure 36 .

Load vs. load-line displacement curve for Type 304L SS SA weld $\mathrm{HAZ}$ tested in air at $289^{\circ} \mathrm{C}$. 
The final crack size was marked by fatigue cycling at room temperature. The specimen was then fractured, and the final crack length of both halves of the fractured specimen was measured from the photograph of the fracture surface (Fig. 37 ). The actual crack extension was $\approx 27 \%$ greater than the value determined from the DC potential measurements. Crack extensions estimated from the DC potential method were adjusted accordingly. The side and end views of the two broken halves of the specimen, shown in Fig. 38, indicate a relatively straight crack plane. The results for the CGR test, including the allowed $\mathrm{K}_{\max }$ from the $\mathrm{K} /$ size criterion, are given in Table 11; the changes in crack length, CGR, and $\mathrm{K}_{\max }$ with time are given in Fig. 39.

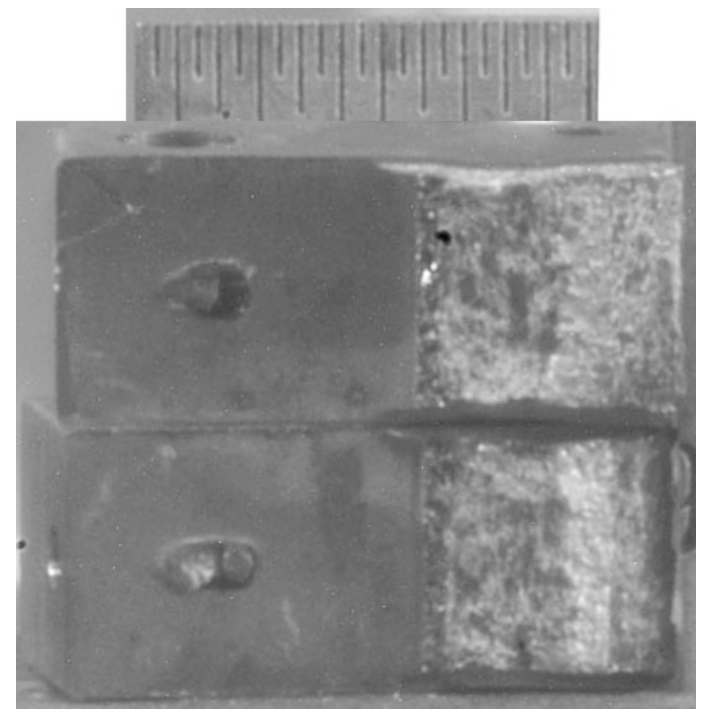

Figure 37.

Photograph of the fracture surface of Type 304L SS SA weld HAZ tested in air at $289^{\circ} \mathrm{C}$.
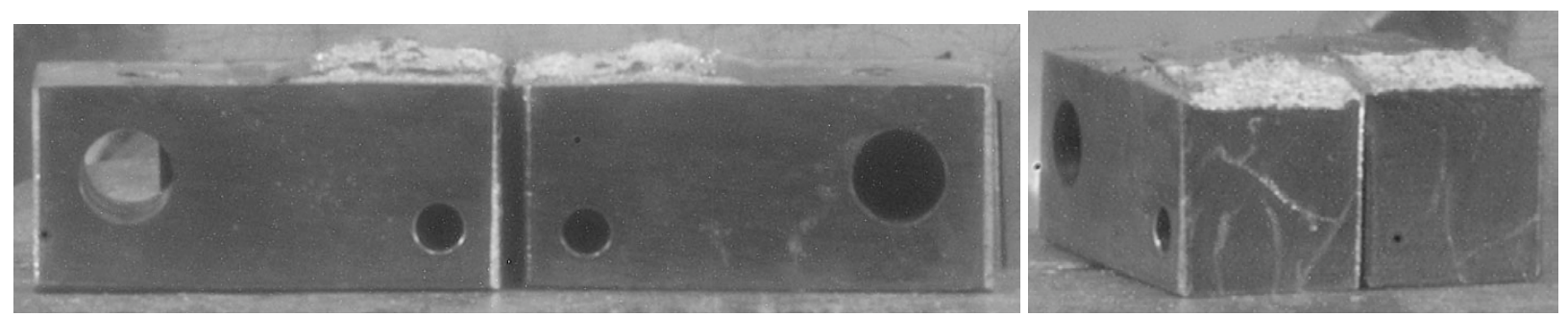

Figure 38. Fracture pieces of Type 304L SS SA weld HAZ: (a) side view and (b) end view.

Table 11. Test conditions and results for Type 304L SA weld HAZ specimen GG6T-Ba in air at $289^{\circ} \mathrm{C}$.

\begin{tabular}{|c|c|c|c|c|c|c|c|c|c|c|c|}
\hline $\begin{array}{c}\text { Test } \\
\text { Period }\end{array}$ & $\begin{array}{c}\text { Test } \\
\text { Time, } \\
\mathrm{h}\end{array}$ & $\begin{array}{c}\mathrm{R} \\
\text { Load } \\
\text { Ratio } \\
\end{array}$ & $\begin{array}{c}\text { Rise } \\
\text { Time, } \\
\mathrm{s}\end{array}$ & $\begin{array}{c}\text { Return } \\
\text { Time, } \\
\mathrm{s}\end{array}$ & $\begin{array}{c}\text { Hold } \\
\text { Time, } \\
\text { s }\end{array}$ & $\begin{array}{c}\mathrm{K}_{\max } \\
\mathrm{MPa} \mathrm{m}^{1 / 2} \\
\end{array}$ & $\begin{array}{c}\Delta \mathrm{K}, \\
\mathrm{MPa} \mathrm{m}^{1 / 2}\end{array}$ & $\begin{array}{c}\text { Growth } \\
\text { Rate, } \\
\mathrm{m} / \mathrm{s}\end{array}$ & $\begin{array}{c}\text { Allowed } \\
\mathrm{K}_{\max }, \\
\text { MPa m}^{1 / 2}\end{array}$ & $\begin{array}{c}\mathrm{K}_{\max }{ }^{-} \\
\mathrm{K}_{\text {allowed }}{ }^{\mathrm{c}} \\
\% \%\end{array}$ & $\begin{array}{c}\text { Crack } \\
\text { Length }^{\mathrm{d}} \\
\mathrm{mm} \\
\end{array}$ \\
\hline & & & & & & & & & & & 5.831 \\
\hline Pre a & 2 & 0.19 & 0.21 & 0.21 & $0.04 / 0.04$ & 17.7 & 14.3 & $9.10 \mathrm{E}-08$ & 21.1 & -16 & 5.988 \\
\hline Pre $b$ & 5 & 0.21 & 0.20 & 0.20 & $0.05 / 0.05$ & 17.5 & 13.9 & 7.69E-08 & 20.6 & -15 & 6.258 \\
\hline 1 & 48 & 0.35 & 23.1 & 3.1 & $6.9 / 0.9$ & 16.5 & 10.8 & $4.29 \mathrm{E}-10$ & 20.5 & -20 & 6.311 \\
\hline 2 & 72 & 0.32 & 4.7 & 1.6 & $1.3 / 0.4$ & 17.0 & 11.6 & $2.44 \mathrm{E}-09$ & 20.3 & -16 & 6.426 \\
\hline
\end{tabular}




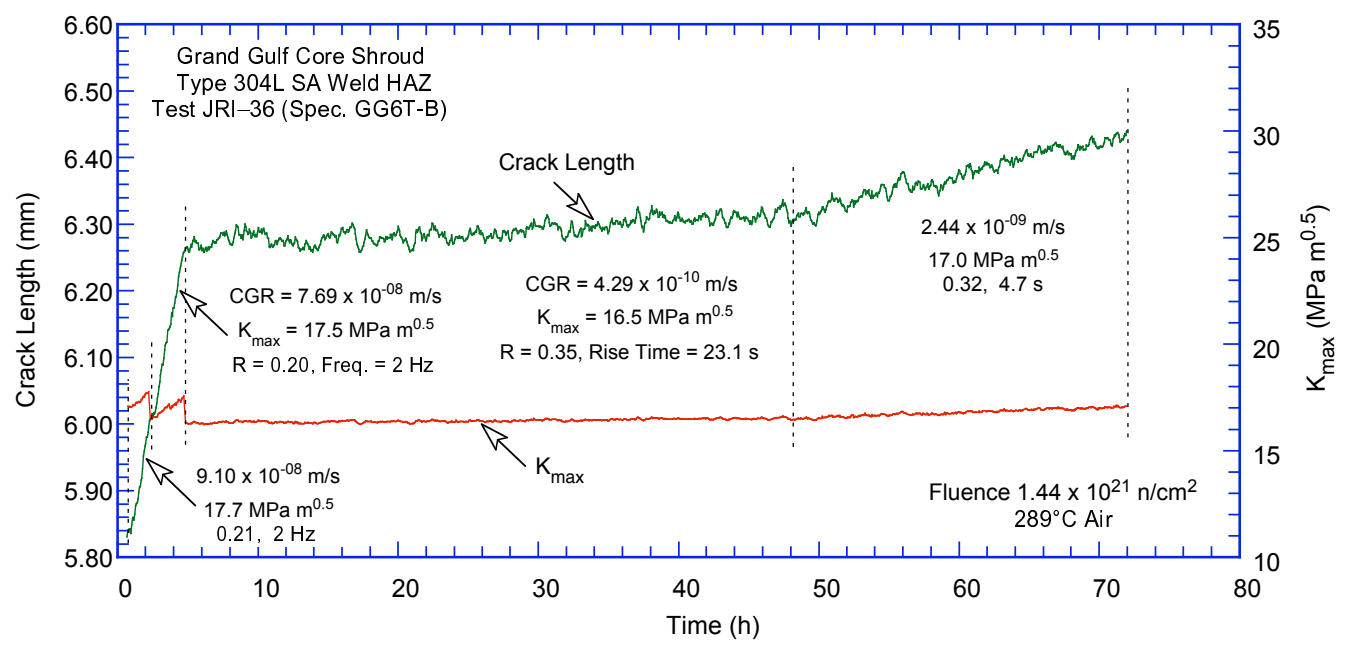

Figure 39. Crack-length-vs.-time plot for Type $304 \mathrm{~L} \mathrm{SS} \mathrm{SA} \mathrm{weld} \mathrm{HAZ} \mathrm{in} \mathrm{air} \mathrm{at} 289^{\circ} \mathrm{C}$ from precracking to test period 4.

The DC potential data during the J-R curve test were also corrected to account for the effects of plasticity on the measured potential. The fracture toughness J-R curve for Specimen GG6T-B in air is shown in Fig. 40; the actual data for the J-R curve test are given in Appendix B, Table B9. The results yield a $\mathrm{J}_{\mathrm{Ic}}$ value of $125 \mathrm{~kJ} / \mathrm{m}^{2}$. For the GG core shroud SA weld HAZ material, the J-R curve in air is comparable to that in NWC BWR water (Fig. 29).

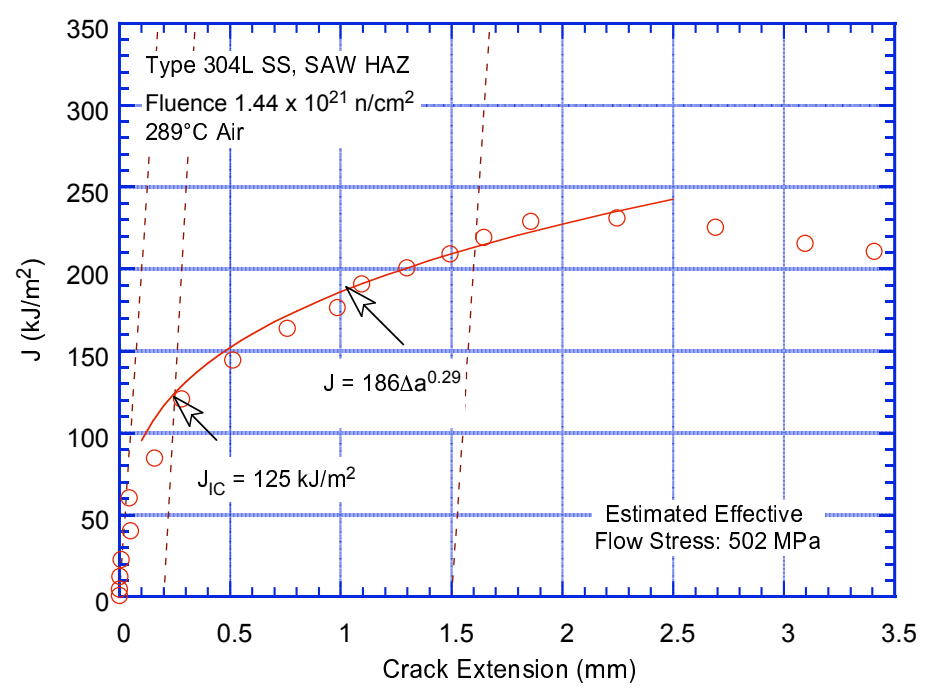

Figure 40.

Fracture toughness $\mathrm{J}-\mathrm{R}$ curve for Type 304L SS SA weld HAZ irradiated to $2.16 \mathrm{dpa}$ tested in air at $289^{\circ} \mathrm{C}$.

\subsection{Cast CF-8M Stainless Steel}

Crack growth and fracture toughness J-R curve tests have been completed in BWR environments at $289^{\circ} \mathrm{C}$ on $1 / 4-\mathrm{T} \mathrm{CT}$ specimens of cast CF-8M SS that were thermally aged for $10,000 \mathrm{~h}$ at $400^{\circ} \mathrm{C}\left(752^{\circ} \mathrm{F}\right)$ and then irradiated to $\approx 2.46 \mathrm{dpa}$. The significant results for the various tests are summarized below.

\subsubsection{Specimen 75-11TT of Thermally Aged CF-8M Cast SS, Test CGRI JR-33}

The CGR test on Specimen 75-11TT was started in high-purity water at a flow rate of $21 \mathrm{~mL} / \mathrm{min}$. The system was operated for a few days to stabilize environmental conditions. The conductivity and DO 
in the feedwater were $0.07 \mu \mathrm{S} / \mathrm{cm}$ and $\approx 800 \mathrm{ppb}$, respectively, and the DO content in the effluent was $\approx 600 \mathrm{ppb}$. The frictional load was measured to be $\pm 156 \mathrm{~N}( \pm 35 \mathrm{lb})$; the results presented here have been corrected to account for the frictional load.

Fatigue precracking was carried out at $\mathrm{R}=0.45, \mathrm{~K}_{\max } \approx 11.5 \mathrm{MPa} \mathrm{m}{ }^{1 / 2}$, triangular waveform, and frequency of $2 \mathrm{~Hz}$. After $\approx 0.05-\mathrm{mm}(\approx 3.5$-mil $)$ crack extension, the load ratio was increased to $0.5-0.8$ with rise times of 14-177 s and return times of 2-7 s. However, environmental enhancement was not readily achieved for this specimen; the loading conditions for most test periods yielded little or no enhancement in CGRs. Finally, the specimen was subjected to a constant load $\left(\mathrm{K}_{\max }=17.5 \mathrm{MPa}\right)$ to obtain the SCC growth rate.

After determination of the SCC growth rate, a J-R test was performed on the specimen at $289^{\circ} \mathrm{C}$ $\left(552^{\circ} \mathrm{F}\right)$ in high-DO water $(\approx 600 \mathrm{ppb} \mathrm{DO})$. The test was conducted at a constant extension rate of $\approx 0.43 \mu \mathrm{m} / \mathrm{s}(0.017 \mathrm{mil} / \mathrm{s})$. The test was interrupted periodically (by holding the specimen at constant extension) to measure the crack length from the DC potential drop. The load vs. extension curve and the load vs. load-line displacement curve for Specimen 75-11TT are shown in Fig. 41. After the onset of crack extension, two large, abrupt load drops $(\approx 1.2$ and $0.7 \mathrm{kN})$ were observed. These load drops resulted in two large crack extensions of $\approx 0.9$ and $0.6 \mathrm{~mm}$, respectively.

The final crack size was marked by fatigue cycling at room temperature. The specimen was then fractured, and the final crack length of both halves of the fractured specimen was measured from photographs of the fracture surface for the two broken halves (Fig. 42). The actual crack extension was comparable to the value determined from the DC potential measurements; therefore, no correction was needed for the crack length measurements. The side view of the two broken halves of Specimen 75-11TT (Fig. 43) indicates a relatively straight crack plane. The results for the CGR test, including the allowed $\mathrm{K}_{\max }$ from the $\mathrm{K} /$ size criterion, are given in Table 12; the changes in crack length, CGR, and $\mathrm{K}_{\max }$ with time are given in Fig. 44.

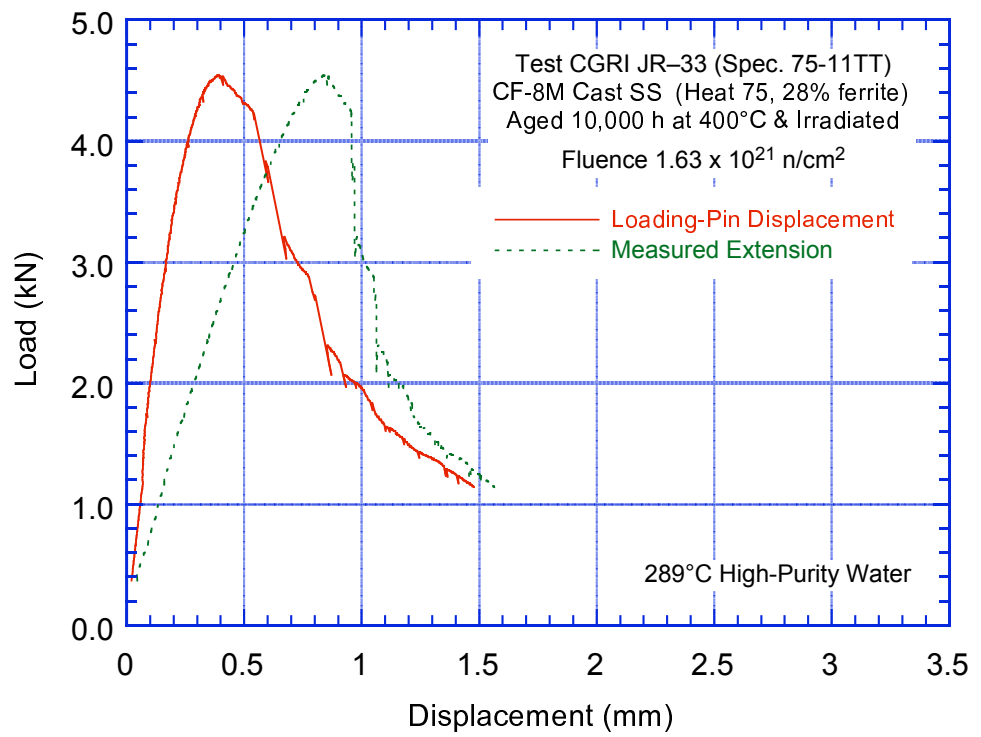

Figure 41.

Load vs. load-line displacement curve for CF-8M cast SS (Specimen 75-11TT) tested in high-purity water. 

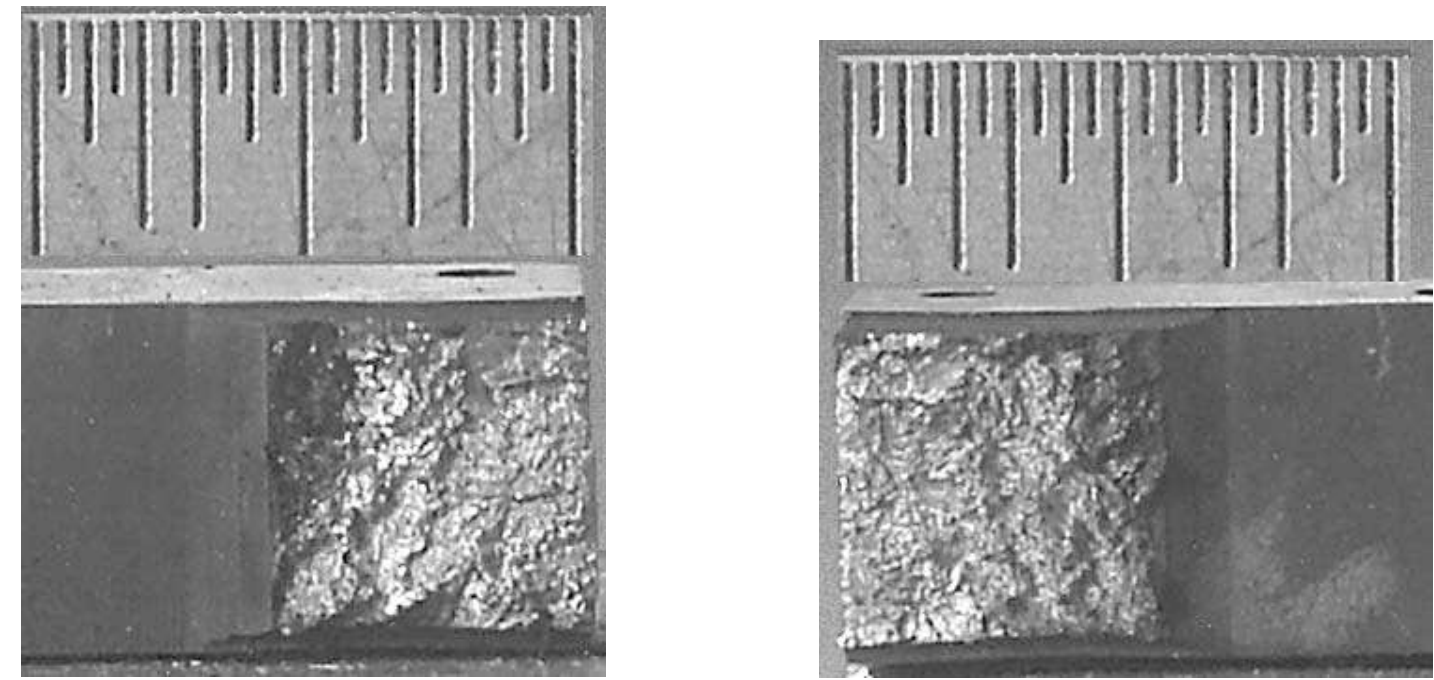

Figure 42. Photographs of the fracture surface of the two halves of CF-8M cast SS (Specimen 75-11TT).

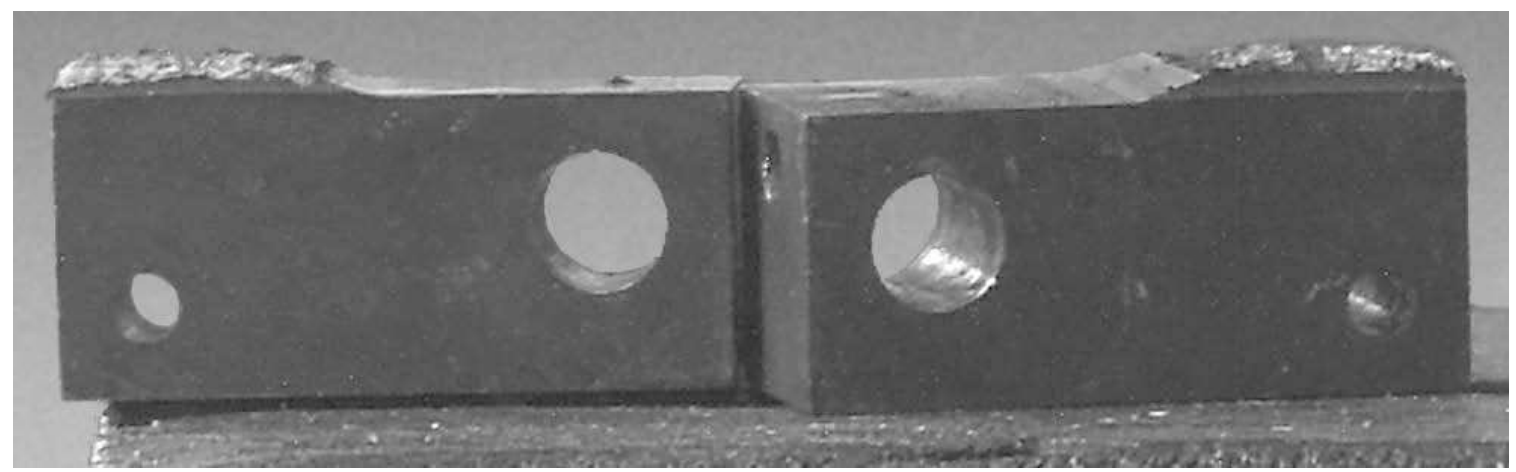

Figure 43. Side view of the fractured pieces of CF-8M cast SS (Specimen 75-11TT).

Table 12. Test conditions and results for thermally aged CF-8M Specimen 75-11TT'a in BWR water at $289^{\circ} \mathrm{C}$.

\begin{tabular}{|c|c|c|c|c|c|c|c|c|c|c|c|c|c|}
\hline $\begin{array}{l}\text { Test } \\
\text { Period }\end{array}$ & $\begin{array}{c}\text { Test } \\
\text { Time, } \\
\mathrm{h}\end{array}$ & $\begin{array}{c}\mathrm{E} \\
\mathrm{mV} \\
\mathrm{Pt}\end{array}$ & $\begin{array}{l}P^{b} \\
\text { Steel }\end{array}$ & $\begin{array}{c}\mathrm{O}_{2} \\
\text { Conc., } \\
\text { ppb }\end{array}$ & $\begin{array}{c}\mathrm{R} \\
\text { Load } \\
\text { Ratio }\end{array}$ & $\begin{array}{l}\text { Rise } \\
\text { Time, } \\
\text { S }\end{array}$ & $\begin{array}{c}\text { Return } \\
\text { Time, } \\
\text { s }\end{array}$ & $\begin{array}{l}\text { Hold } \\
\text { Time, } \\
\text { s }\end{array}$ & $\begin{array}{c}\mathrm{K}_{\max }, \\
\mathrm{MPa} \mathrm{m}^{1 / 2}\end{array}$ & $\begin{array}{c}\Delta \mathrm{K}, \\
\mathrm{MPa} \mathrm{m}^{1 / 2}\end{array}$ & $\begin{array}{c}\text { Growth } \\
\text { Rate, } \\
\mathrm{m} / \mathrm{s}\end{array}$ & $\begin{array}{c}\text { Allowed } \\
\mathrm{K}_{\max },{ }^{d} \\
\mathrm{MPa} \mathrm{m}^{1 / 2}\end{array}$ & $\begin{array}{c}\text { Crack } \\
\text { Length, } \\
\text { mm }\end{array}$ \\
\hline Pre a & 78 & 169 & 201 & 600 & 0.46 & 0.14 & 0.14 & $0.11 / 0.11$ & 11.3 & 6.1 & $2.70 \mathrm{E}-08$ & 23.1 & $\begin{array}{l}6.043 \\
6.071\end{array}$ \\
\hline Pre b & 102 & 213 & 234 & 600 & 0.45 & 0.14 & 0.14 & $0.11 / 0.11$ & 11.2 & 6.2 & 2.69E-09 & 23.1 & 6.090 \\
\hline Pre c & 118 & 212 & 232 & 600 & 0.45 & 14.3 & 14.3 & $10.7 / 10.7$ & 11.2 & 6.1 & $5.35 \mathrm{E}-11$ & 23.1 & 6.093 \\
\hline Pre d & 126 & 216 & 236 & 600 & 0.58 & 0.13 & 0.13 & $0.12 / 0.12$ & 11.2 & 4.7 & $3.52 \mathrm{E}-09$ & 23.0 & 6.109 \\
\hline $1 \mathrm{a}$ & 142 & 213 & 232 & 600 & 0.82 & 18.0 & 4.0 & $42.0 / 8.0$ & 10 & 1.9 & $1.48 \mathrm{E}-10$ & 23.0 & 6.112 \\
\hline $1 b$ & 150 & 214 & 233 & 600 & 0.53 & 17.2 & 2.3 & $12.8 / 1.7$ & 13.4 & 6.3 & $4.38 \mathrm{E}-10$ & 23.0 & 6.119 \\
\hline $1 \mathrm{c}$ & 216 & 213 & 229 & 600 & 0.53 & 34.8 & 7.0 & $25.2 / 5.0$ & 13.5 & 6.3 & $5.69 \mathrm{E}-11$ & 23.0 & 6.125 \\
\hline 2 & 286 & 209 & 221 & 600 & 0.68 & 155 & 6.2 & $145 / 25.8$ & 15.4 & 4.9 & $1.39 \mathrm{E}-11$ & 23.0 & 6.128 \\
\hline 3 & 312 & 211 & 222 & 600 & 0.50 & 7.7 & 1.3 & $4.3 / 0.7$ & 17.1 & 8.5 & $8.55 \mathrm{E}-10$ & 22.9 & 6.163 \\
\hline 4 & 360 & 215 & 225 & 600 & 0.60 & 177 & 7.0 & $123 / 5.0$ & 17.1 & 6.8 & $3.10 \mathrm{E}-11$ & 22.9 & 6.167 \\
\hline 5 & 405 & 216 & 225 & 600 & 0.50 & 7.7 & 1.3 & $4.3 / 0.7$ & 17.1 & 8.5 & $9.64 \mathrm{E}-10$ & 22.8 & 6.251 \\
\hline 6 & 433 & 216 & 224 & 600 & 0.50 & 77.0 & 2.6 & $43.0 / 1.4$ & 17.3 & 8.6 & $2.50 \mathrm{E}-10$ & 22.7 & 6.302 \\
\hline 7 & 550 & 210 & 217 & 600 & 1.00 & - & - & - & 17.5 & 0.0 & $1.24 \mathrm{E}-10$ & 22.6 & 6.338 \\
\hline
\end{tabular}

${ }^{\mathrm{a}}$ Cast austenitic SS (Heat 75$)$, thermally aged for $10,000 \mathrm{~h}$ at $400^{\circ} \mathrm{C}$ and then irradiated to $1.63 \times 10^{21} \mathrm{n} / \mathrm{cm}^{2}(2.46 \mathrm{dpa})$ at $\approx 297^{\circ} \mathrm{C}$.

${ }^{b}$ Represents values in the effluent. Conductivity and DO were $\approx 0.07 \mu \mathrm{S} / \mathrm{cm}$ and $800 \mathrm{ppb}$, respectively, in the feedwater.

${ }^{c}$ Hold periods at maximum load during the unloading cycle and at minimum load during the loading cycle.

${ }^{\mathrm{d}}$ Based on effective yield stress, defined as the average of irradiated and nonirradiated yield stresses.

${ }^{\mathrm{e}}$ The difference between the measured crack extension and that determined from the DC potential drop measurements was $<5 \%$. 


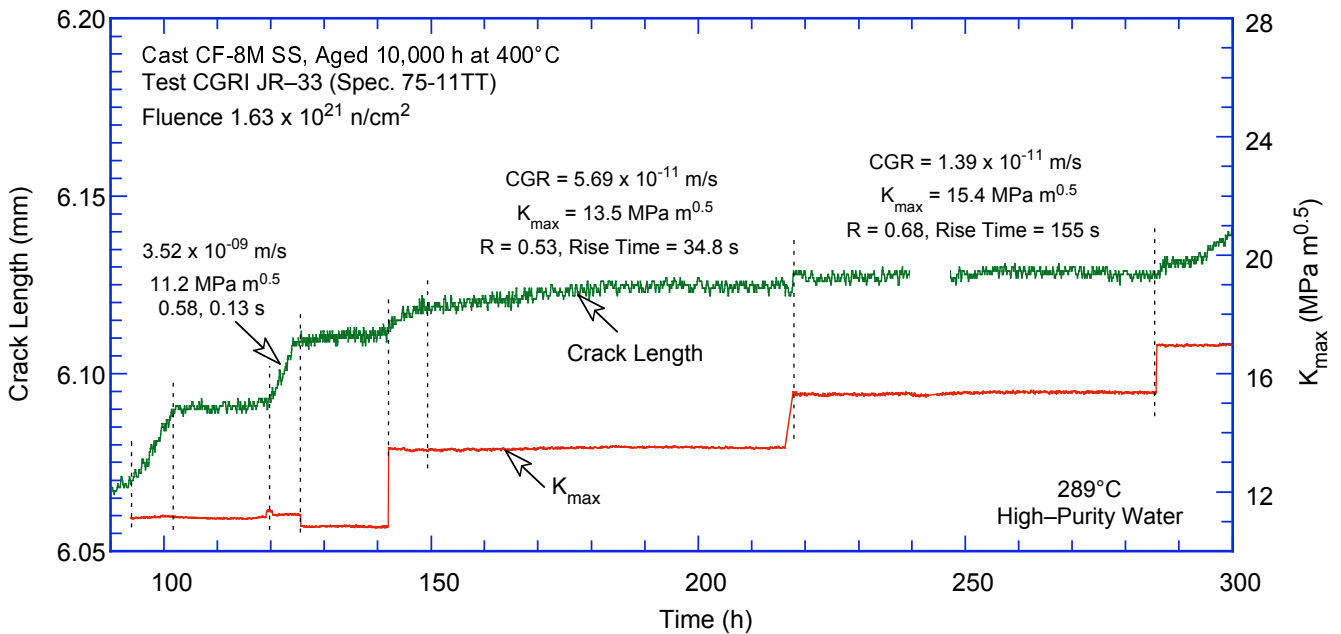

(a)

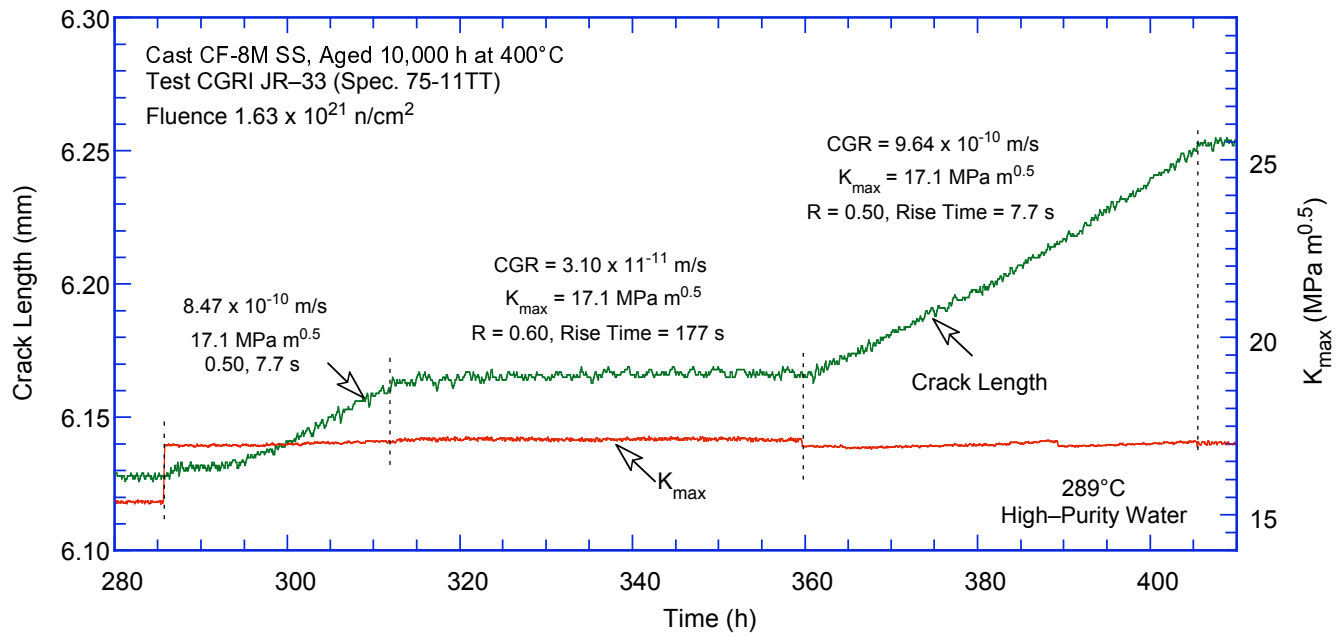

(b)

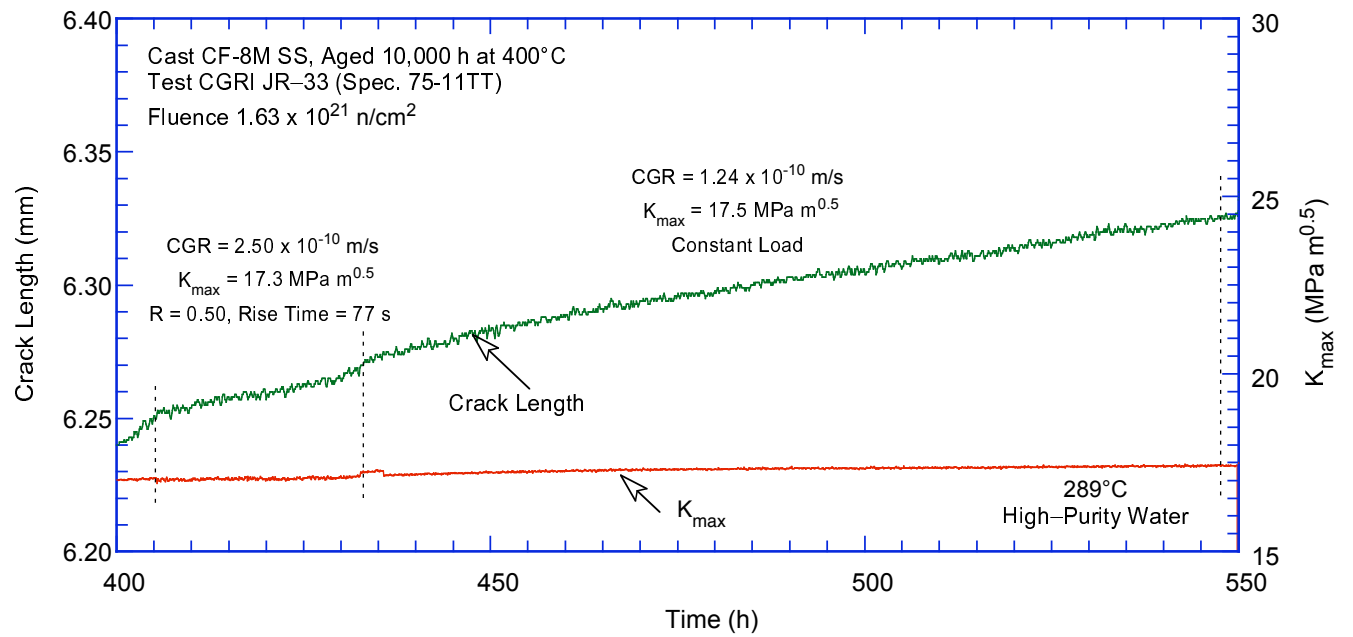

(c)

Figure 44. Crack-length-vs.-time plot for CF-8M cast SS (Specimen 75-11TT) in BWR water at $289^{\circ} \mathrm{C}$ for test periods (a) precracking-3, (b) 3-5, and (c) 6-7. 
The DC potential data were corrected to account for the effects of plasticity on the measured potential. The fracture toughness J-R curve for Specimen 75-11TT in high-DO water is shown in Fig. 45; the actual data for the test are presented in Appendix B, Table B10. The results yield a $\mathrm{J}_{\text {Ic }}$ value of $84 \mathrm{~kJ} / \mathrm{m}^{2}$ (480 in.-lb/in. ${ }^{2}$ ). As noted earlier, the two abrupt load drops (Fig. 41) resulted in uncontrolled crack extensions of $\approx 0.9$ and $0.6 \mathrm{~mm}$, respectively. However, the specimen showed controlled crack extension after these two load drops.

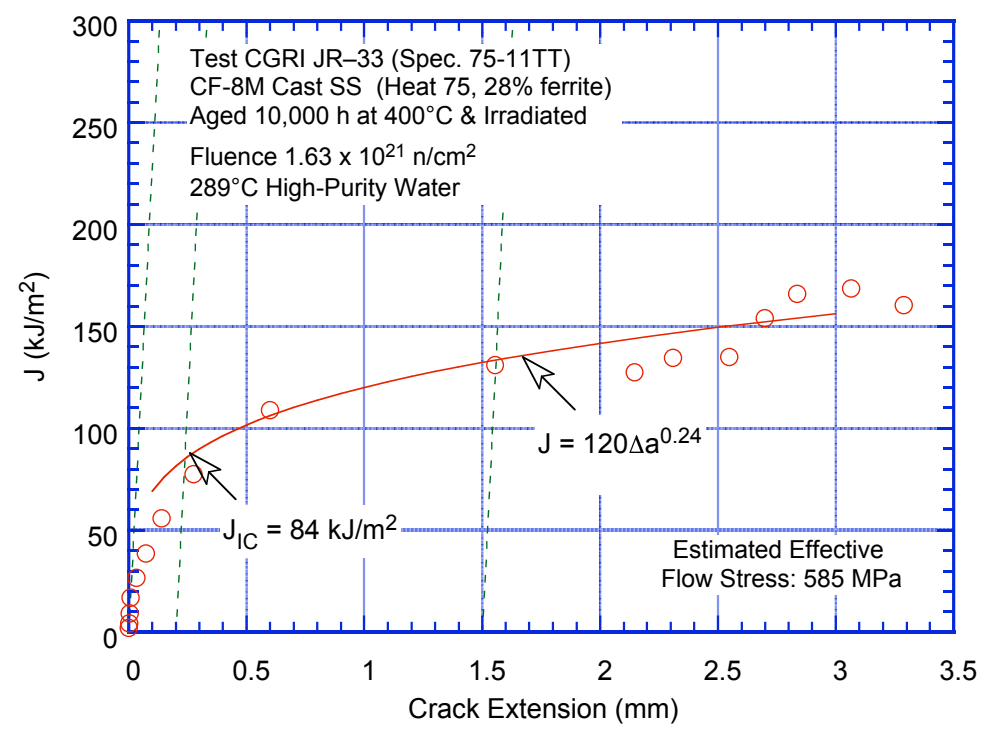

Figure 45.

Fracture toughness J-R curve for thermally aged and irradiated cast CF-8M SS (Specimen 75-11TT) in high-DO water at $289^{\circ} \mathrm{C}$.

\subsubsection{Specimen 75-11TM of Thermally Aged CF-8M Cast SS, Test CGRI JR-34}

The CGR test on Specimen 75-11TM was started in high-purity water at a flow rate of $20 \mathrm{~mL} / \mathrm{min}$. The conductivity and DO in the feedwater were $0.07 \mu \mathrm{S} / \mathrm{cm}$ and $\approx 800 \mathrm{ppb}$, respectively, and the DO content in the effluent was $\approx 600 \mathrm{ppb}$. The frictional load was measured to be $\pm 120 \mathrm{~N}( \pm 27 \mathrm{lb})$; the results presented here have been corrected to account for the frictional load.

Fatigue precracking was carried out at $\mathrm{R}=0.50, \mathrm{~K}_{\max } \approx 15.0 \mathrm{MPa} \mathrm{m}{ }^{1 / 2}$, triangular waveform, and frequency of $2 \mathrm{~Hz}$. After $\approx 0.14-\mathrm{mm}(5.5-\mathrm{mil})$ crack extension, the load ratio was increased incrementally to 0.8 with rise times of $37-435 \mathrm{~s}$ and return times of 2-6 s. Environmental enhancement was readily achieved for this specimen of thermally aged cast SS. Finally, the specimen was subjected to a constant load (corresponding to $\mathrm{K}_{\max }=14.7,10.7$, and $7.6 \mathrm{MPa} \mathrm{m}{ }^{1 / 2}$ ) to obtain $\mathrm{SCC}$ growth rates.

After completion of the SCC growth rate test, a J-R test was performed on the specimen at $289^{\circ} \mathrm{C}$ $\left(552^{\circ} \mathrm{F}\right)$ in high-DO water $(\approx 600 \mathrm{ppb} \mathrm{DO})$. The test was conducted at a constant extension rate of $\approx 0.43 \mu \mathrm{m} / \mathrm{s}(0.017 \mathrm{mil} / \mathrm{s})$. The load vs. extension and the load vs load-line displacement curves for Specimen 75-11TM are shown in Fig. 46. After the onset of crack extension, a few large, abrupt load drops were observed. These load drops resulted in crack extensions of $\approx 0.4-0.5 \mathrm{~mm}$ (16-20 mil).

The final crack size was marked by fatigue cycling at room temperature. The specimen was then fractured, and the final crack length of both halves of the fractured specimen was measured from photographs of the fracture surface for the two broken halves (Fig. 47a). The actual crack extension was comparable to the value determined from the DC potential measurements; therefore, no correction was needed for the crack length measurements. The end view of the two broken halves of the specimen 
(Fig. 47b) indicates a relatively straight crack plane. The results for the CGR test, including the allowed $\mathrm{K}_{\max }$ from the $\mathrm{K} /$ size criterion, are given in Table 13; the changes in crack length, CGR, and $\mathrm{K}_{\max }$ with time are given in Fig. 48.

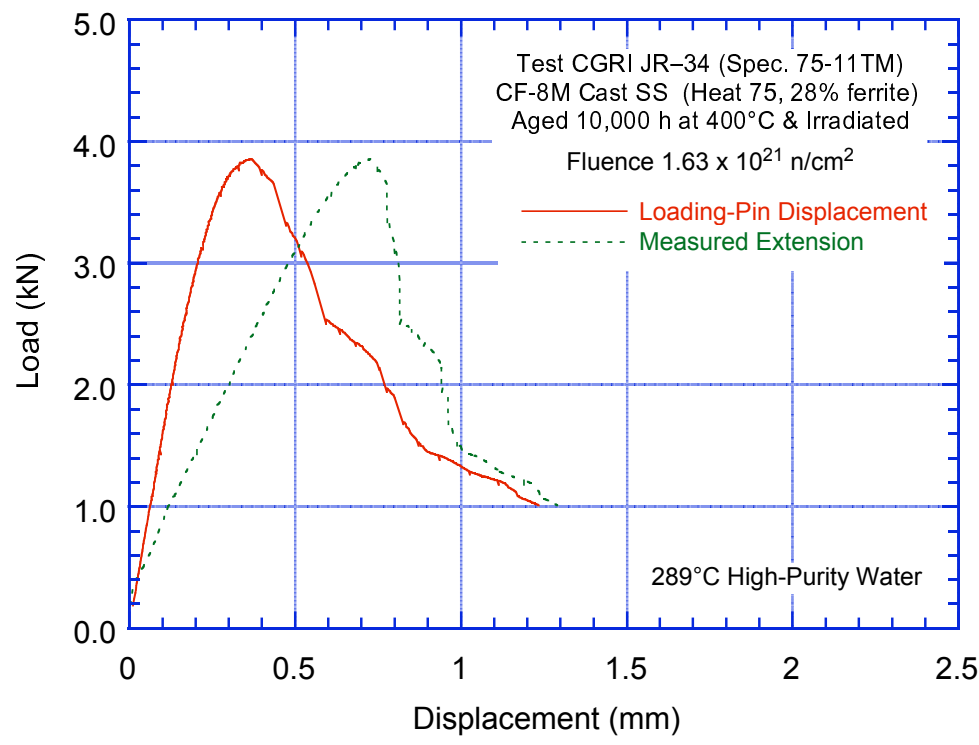

Figure 46.

Load vs. load-line displacement curve for CF-8M cast SS (Specimen 75-11TM) tested in high-purity water.

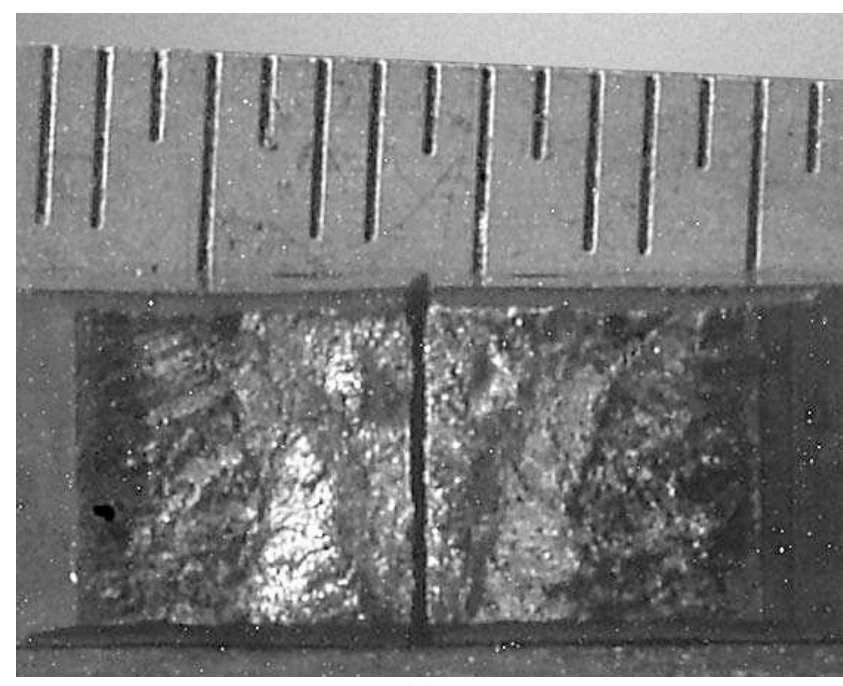

(a)

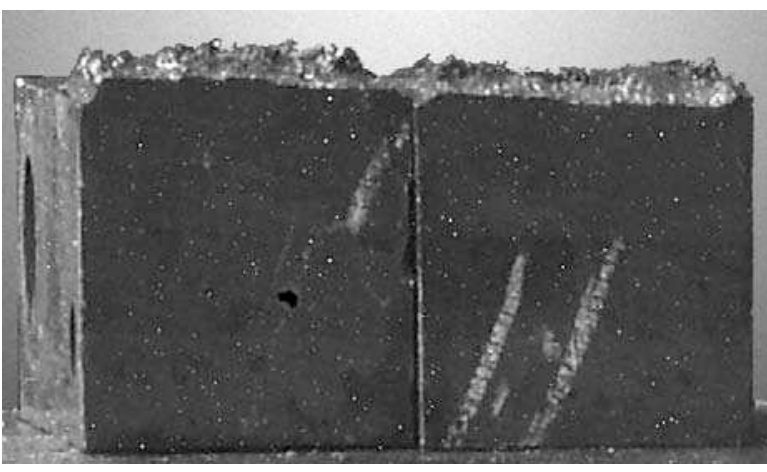

(b)

Figure 47. Photographs of the (a) fracture surface and (b) end view of the two halves of CF-8M cast SS (Specimen 75-11TM).

The DC potential data were corrected to account for the effects of plasticity on the measured potential. The fracture toughness J-R curve for Specimen 75-11TM in high-DO water is shown in Fig. 49. The actual data for the test are presented in Appendix B, Table B11. The results yield a $\mathrm{J}_{\text {Ic }}$ value of $40 \mathrm{~kJ} / \mathrm{m}^{2}$ (228 in.-lb/in. ${ }^{2}$ ) Note that the three abrupt load drops (Fig. 46) resulted in uncontrolled crack extensions of $\approx 0.4-0.5 \mathrm{~mm}$. However, the specimen showed controlled crack extension after these load drops. 
Table 13. Test conditions and results for thermally aged CF-8M Specimen $75-11$ TM $^{\mathrm{a}}$ in BWR water at $289^{\circ} \mathrm{C}$.

\begin{tabular}{|c|c|c|c|c|c|c|c|c|c|c|c|c|c|}
\hline $\begin{array}{l}\text { Test } \\
\text { Period }\end{array}$ & $\begin{array}{c}\text { Test } \\
\text { Time, } \\
\mathrm{h}\end{array}$ & $\begin{array}{r}\mathrm{E} \\
\mathrm{mV} \\
\mathrm{Pt}\end{array}$ & $\begin{array}{l}\mathrm{P}^{\mathrm{b}} \\
\text { SHE) } \\
\text { Steel }\end{array}$ & $\begin{array}{c}\mathrm{O}_{2} \\
\text { Conc., } \\
\text { ppb }\end{array}$ & $\begin{array}{c}\mathrm{R} \\
\text { Load } \\
\text { Ratio }\end{array}$ & $\begin{array}{c}\text { Rise } \\
\text { Time, } \\
\text { s }\end{array}$ & $\begin{array}{c}\text { Return } \\
\text { Time, } \\
\text { s }\end{array}$ & $\begin{array}{c}\text { Hold } \\
\text { Time, } \\
\text { s }\end{array}$ & $\begin{array}{c}\mathrm{K}_{\text {max }}, \\
\mathrm{MPa} \mathrm{m}^{1 / 2}\end{array}$ & $\begin{array}{c}\Delta \mathrm{K}, \\
\mathrm{MPa} \mathrm{m}^{1 / 2}\end{array}$ & $\begin{array}{c}\text { Growth } \\
\text { Rate, } \\
\mathrm{m} / \mathrm{s}\end{array}$ & $\begin{array}{c}\text { Allowed } \\
\mathrm{K}_{\max }{ }^{d} \\
\mathrm{MPa} \mathrm{m}^{1 / 2}\end{array}$ & $\begin{array}{c}\text { Crack } \\
\text { Length, } \\
\mathrm{mm}\end{array}$ \\
\hline Pre & 72 & 226 & 229 & 600 & 0.49 & 0.17 & 0.17 & $0.08 / 0.08$ & 15.0 & 7.6 & $3.02 \mathrm{E}-08$ & 22.9 & $\begin{array}{l}6.030 \\
6.166\end{array}$ \\
\hline 1 & 114 & 227 & 230 & 600 & 0.59 & 37 & 2.5 & $23 / 1.5$ & 14.6 & 6.1 & $6.43 \mathrm{E}-10$ & 22.8 & 6.224 \\
\hline 2 & 162 & 226 & 229 & 600 & 0.72 & 159 & 6.4 & $141 / 5.6$ & 14.8 & 4.2 & $3.61 \mathrm{E}-10$ & 22.7 & 6.256 \\
\hline 3 & 234 & 225 & 228 & 600 & 0.81 & 435 & 5.2 & $565 / 6.8$ & 14.9 & 2.9 & $2.84 \mathrm{E}-10$ & 22.7 & 6.289 \\
\hline 4 & 264 & 224 & 226 & 600 & 1.00 & - & - & - & 14.7 & 0.0 & $4.27 \mathrm{E}-10$ & 22.6 & 6.335 \\
\hline 5 & 354 & 218 & 220 & 600 & 1.00 & - & - & - & 10.7 & 0.0 & $1.72 \mathrm{E}-10$ & 22.5 & 6.376 \\
\hline 6 & 450 & 209 & 209 & 600 & 1.00 & - & - & - & 7.6 & 0.0 & $2.84 \mathrm{E}-11$ & 22.5 & 6.384 \\
\hline
\end{tabular}

${ }^{\mathrm{a}}$ Cast austenitic SS (Heat 75), thermally aged for $10,000 \mathrm{~h}$ at $400^{\circ} \mathrm{C}$ and then irradiated to $1.63 \times 10^{21} \mathrm{n} / \mathrm{cm}^{2}(2.46 \mathrm{dpa})$ at $\approx 297^{\circ} \mathrm{C}$.

${ }^{b}$ Represents values in the effluent. Conductivity and DO were $\approx 0.07 \mu \mathrm{S} / \mathrm{cm}$ and $800 \mathrm{ppb}$, respectively, in the feedwater.

${ }^{\mathrm{c}}$ Hold periods at maximum load during the unloading cycle and at minimum load during the loading cycle.

${ }^{\mathrm{d}}$ Based on effective yield stress, defined as the average of irradiated and nonirradiated yield stresses.

${ }^{\mathrm{e}}$ The difference between the measured crack extension and that determined from the DC potential drop measurements was $<5 \%$.

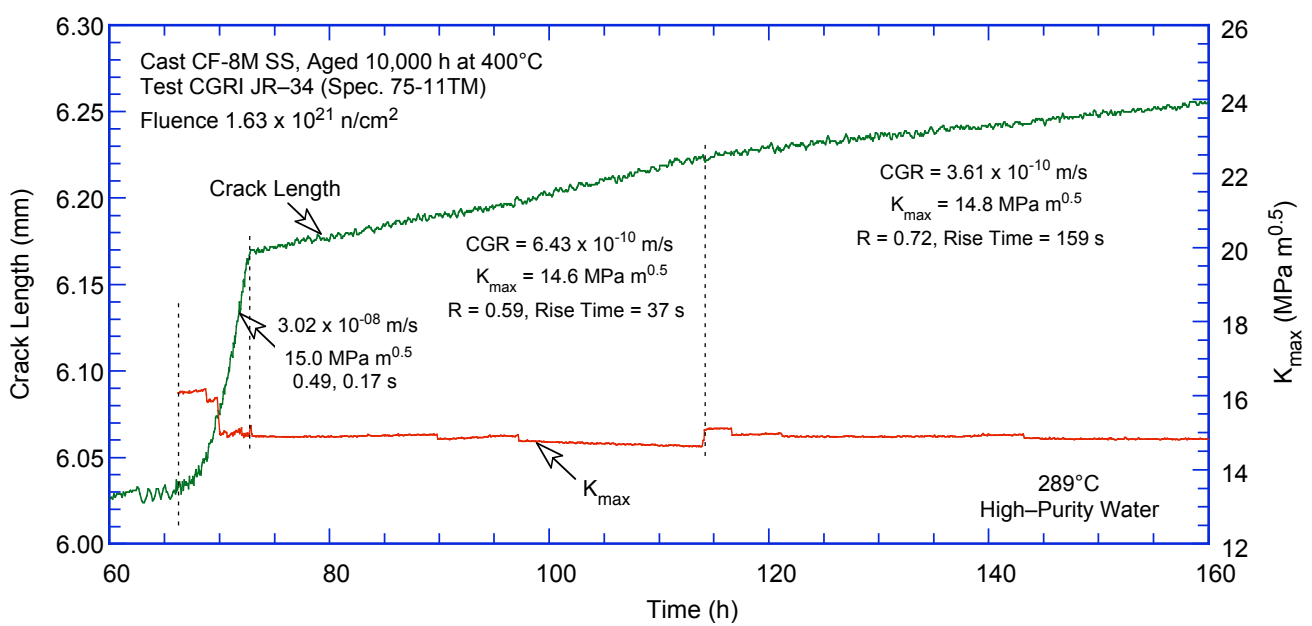

(a)

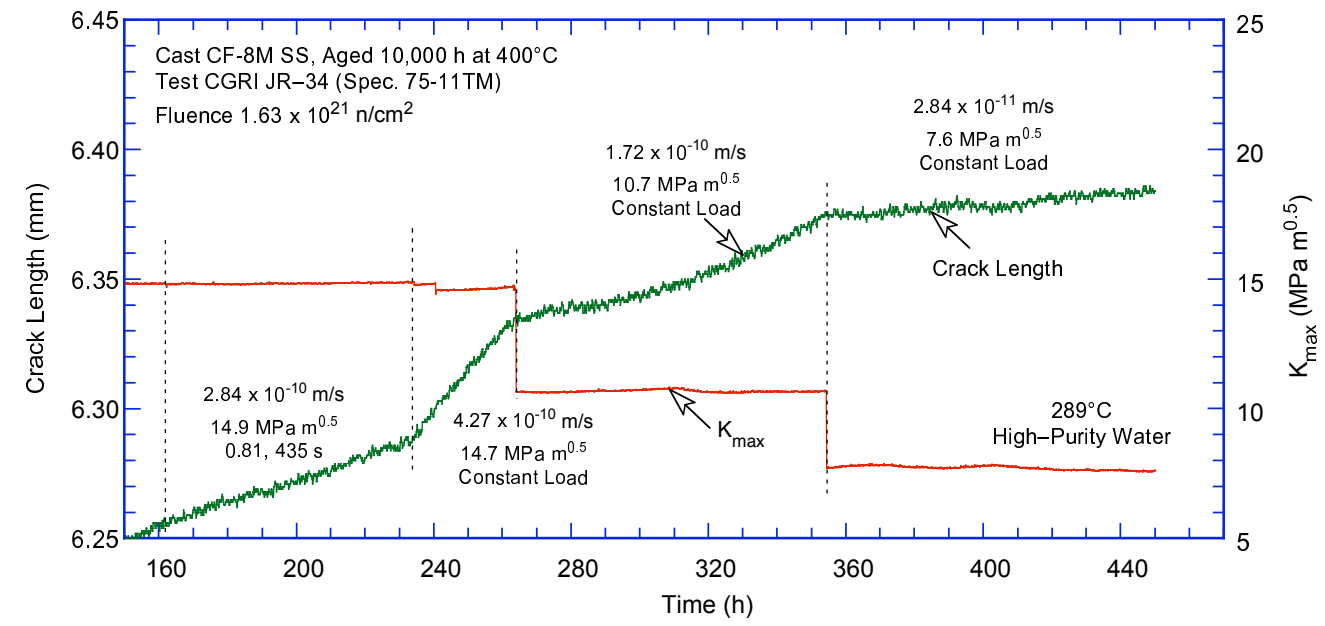

(b)

Figure 48. Crack-length-vs.-time plot for CF-8M cast SS (Specimen $85-3 T M$ ) in BWR water at $289^{\circ} \mathrm{C}$ for test periods (a) precracking-3, (b) 3-5, and (c) 6-7. 


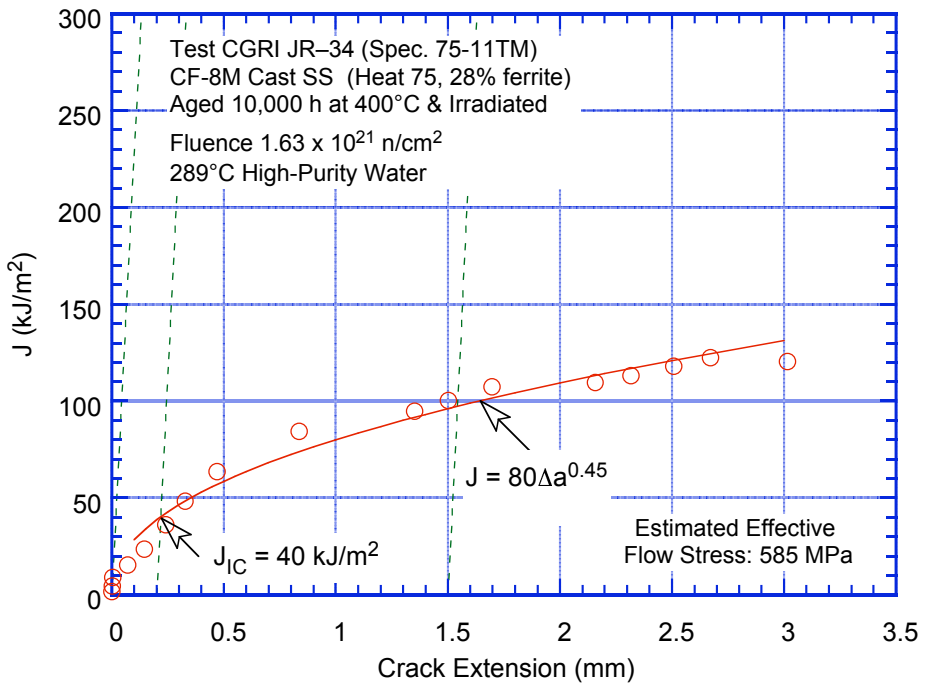

Figure 49.

Fracture toughness $\mathrm{J}-\mathrm{R}$ curve for thermally aged and irradiated cast CF-8M SS (Specimen 75-11TM) in high-DO water at $289^{\circ} \mathrm{C}$. 


\section{Discussion}

\subsection{CGRs under Constant Load with or without Periodic Partial Unloading}

The constant-load CGRs from the present study and those obtained earlier at ANL 27,54 are compiled in Table 14. Most of the tests were conducted under constant load with or without periodic partial unloading to $\mathrm{R}=0.7$ every 1-3 h. The unloading/reloading period was $24 \mathrm{~s}$ for all tests except for the test on Specimen C3-B, which used a 4-s unloading/reloading period. The results indicate that periodic partial unloading has little or no effect on constant-load CGRs. A few tests were conducted using a trapezoidal waveform having rise and return times of 300-500 and $12 \mathrm{~s}$, respectively. For these tests, the experimental CGRs were adjusted for the contribution of corrosion fatigue by using the cyclic CGR data obtained with a saw-tooth waveform (i.e., without a hold period at peak stress). The adjusted values (i.e., constant-load CGRs) are listed within parentheses in Table 14. For the loading conditions used in these tests, the CGRs under cyclic loading were comparable to those under constant load; therefore, the difference between the experimental and adjusted CGRs is relatively small (less than 5\%).

Table 14. Test conditions and constant-load crack growth data in BWR environment at $289^{\circ} \mathrm{C}$.

\begin{tabular}{|c|c|c|c|c|c|c|c|c|c|c|c|}
\hline $\begin{array}{l}\text { Steel } \\
\text { Type }\end{array}$ & Material $^{\mathrm{a}}$ & Condition $^{\mathrm{b}}$ & Heat $^{c}$ & $\begin{array}{l}\text { Spec. } \\
\text { ID }\end{array}$ & $\begin{array}{c}\text { Dose, } \\
\text { dpa }\end{array}$ & $\begin{array}{l}\mathrm{DO}, \\
\mathrm{ppb}\end{array}$ & $\begin{array}{c}\text { ECP, }{ }^{\mathrm{d}} \\
\mathrm{mV}(\mathrm{SHE}) \\
\end{array}$ & $\begin{array}{c}\mathrm{K}_{\max }, \\
\mathrm{MPa} \mathrm{m}^{1 / 2}\end{array}$ & $\begin{array}{c}\mathrm{CGR},{ }^{\mathrm{e}} \\
\mathrm{m} / \mathrm{s}\end{array}$ & Waveform & $\begin{array}{c}\mathrm{K}_{\max }- \\
\mathrm{K}_{\text {allowed }}, \mathrm{f} \%\end{array}$ \\
\hline $304 \mathrm{~L}$ & Base & SA & C3 & C3-A & 0.45 & 300 & 197 & 17.9 & $\begin{array}{c}8.65 \mathrm{E}-11 \\
(9.22 \mathrm{E}-11)\end{array}$ & Trapezoidal & 4.2 \\
\hline $304 \mathrm{~L}$ & Base & SA & C3 & C3-A & 0.45 & 300 & 200 & 22.0 & $\begin{array}{c}1.11 \mathrm{E}-10 \\
(1.17 \mathrm{E}-10)\end{array}$ & Trapezoidal & 28.7 \\
\hline $304 \mathrm{~L}$ & Base & SA & C3 & C3-A & 0.45 & 300 & 203 & 22.3 & $\begin{array}{c}1.13 \mathrm{E}-10 \\
(1.15 \mathrm{E}-10)\end{array}$ & Trapezoidal & 30.9 \\
\hline $304 \mathrm{~L}$ & Base & SA & C3 & C3-B & 1.35 & 300 & 191 & 20.1 & $1.06 \mathrm{E}-09$ & Periodic Unload & 13.5 \\
\hline $304 \mathrm{~L}$ & Base & SA & $\mathrm{C} 3$ & C3-B & 1.35 & 300 & 195 & 22.1 & $1.04 \mathrm{E}-09$ & Periodic Unload & 26.9 \\
\hline $304 \mathrm{~L}$ & Base & SA & $\mathrm{C} 3$ & C3-B & 1.35 & $\approx 10$ & -595 & 22.3 & $4.02 \mathrm{E}-11$ & Periodic Unload & 29.5 \\
\hline $304 \mathrm{~L}$ & Base & SA & C3 & C3-B & 1.35 & $\approx 10$ & -614 & 22.7 & $6.42 \mathrm{E}-12$ & Periodic Unload & 32.5 \\
\hline $304 \mathrm{~L}$ & Base & SA & $\mathrm{C} 3$ & C3-B & 1.35 & 250 & 155 & 24.4 & $8.70 \mathrm{E}-10$ & Periodic Unload & 48.9 \\
\hline $304 \mathrm{~L}$ & Base & SA & $\mathrm{C} 3$ & $\mathrm{C} 3-\mathrm{C}$ & 3.00 & 300 & 164 & 19.4 & $6.83 \mathrm{E}-10$ & Periodic Unload & -7.9 \\
\hline $304 \mathrm{~L}$ & Base & SA & $\mathrm{C} 3$ & $\mathrm{C} 3-\mathrm{C}$ & 3.00 & 100 & 150 & 23.7 & $5.07 \mathrm{E}-10$ & Periodic Unload & 15.5 \\
\hline $304 \mathrm{~L}$ & Base & SA & $\mathrm{C} 3$ & $\mathrm{C} 3-\mathrm{C}$ & 3.00 & $\approx 10$ & -294 & 27.5 & $6.91 \mathrm{E}-10$ & Periodic Unload & 43.9 \\
\hline $304 \mathrm{~L}$ & Base & SA & C3 & $\mathrm{C} 3-\mathrm{C}$ & 3.00 & $\approx 10$ & -502 & 34.7 & 2.04E-09 & Periodic Unload & 111.8 \\
\hline $304 \mathrm{~L}$ & Base & SA & C3 & $\mathrm{C} 3-\mathrm{C}$ & 3.00 & $\approx 10$ & -457 & 37.0 & 3.70E-09 & Periodic Unload & 133.9 \\
\hline $316 \mathrm{~L}$ & Base & SA & $\mathrm{C} 16$ & C16-B & 3.00 & 250 & 117 & 15.2 & $4.62 \mathrm{E}-10$ & Periodic Unload & -29.0 \\
\hline $316 \mathrm{~L}$ & Base & SA & $\mathrm{C} 16$ & C16-B & 3.00 & $<30$ & -298 & 15.3 & $1.90 \mathrm{E}-11$ & Periodic Unload & -28.4 \\
\hline $316 \mathrm{~L}$ & Base & SA & $\mathrm{C} 16$ & C16-B & 3.00 & $<30$ & -554 & 17.3 & $1.73 \mathrm{E}-11$ & Periodic Unload & -18.1 \\
\hline $316 \mathrm{~L}$ & Base & SA & $\mathrm{C} 16$ & C16-B & 3.00 & $<30$ & -597 & 19.7 & $4.11 \mathrm{E}-11$ & Periodic Unload & -6.9 \\
\hline $316 \mathrm{~L}$ & Base & SA & $\mathrm{C} 16$ & C16-B & 3.00 & 250 & 139 & 19.6 & $7.14 \mathrm{E}-10$ & Periodic Unload & -6.7 \\
\hline $316 \mathrm{~L}$ & Base & SA & $\mathrm{C} 16$ & C16-B & 3.00 & 250 & 148 & 21.9 & $1.10 \mathrm{E}-09$ & Periodic Unload & 4.7 \\
\hline 316 & Base & SA & $\mathrm{C} 21$ & C21-A & 0.45 & 350 & $(160)$ & 16.5 & $1.51 \mathrm{E}-10$ & Periodic Unload & -22.0 \\
\hline 316 & Base & SA & $\mathrm{C} 21$ & C21-A & 0.45 & 350 & $(160)$ & 21.8 & $2.46 \mathrm{E}-10$ & Periodic Unload & 3.8 \\
\hline 316 & Base & SA & $\mathrm{C} 21$ & C21-A & 0.45 & 350 & $(160)$ & 22.7 & $2.56 \mathrm{E}-10$ & Const. Load & 9.5 \\
\hline 316 & Base & SA & $\mathrm{C} 21$ & C21-B & 1.35 & 350 & 211 & 16.2 & $9.67 \mathrm{E}-10$ & Const. Load & -22.2 \\
\hline 316 & Base & SA & $\mathrm{C} 21$ & C21-B & 1.35 & $<30$ & -452 & 16.3 & $3.32 \mathrm{E}-11$ & Const. Load & -21.4 \\
\hline 316 & Base & SA & $\mathrm{C} 21$ & C21-B & 1.35 & $<30$ & -551 & 19.6 & $1.24 \mathrm{E}-11$ & Const. Load & -5.4 \\
\hline 316 & Base & SA & $\mathrm{C} 21$ & $\mathrm{C} 21-\mathrm{C}$ & 3.00 & 500 & $(230)$ & 17.6 & $1.06 \mathrm{E}-09$ & Const. Load & -32.7 \\
\hline 316 & Base & SA & $\mathrm{C} 21$ & $\mathrm{C} 21-\mathrm{C}$ & 3.00 & $<30$ & -216 & 17.9 & $1.77 \mathrm{E}-10$ & Const. Load & -30.8 \\
\hline 316 & Base & SA & $\mathrm{C} 21$ & $\mathrm{C} 21-\mathrm{C}$ & 3.00 & 450 & 114 & 18.1 & $9.18 \mathrm{E}-10$ & Const. Load & -29.4 \\
\hline 316 & Base & SA & $\mathrm{C} 21$ & C21-C & 3.00 & 450 & 124 & 23.6 & $1.21 \mathrm{E}-09$ & Const. Load & -5.4 \\
\hline 316 & Base & SA & $\mathrm{C} 21$ & $\mathrm{C} 21-\mathrm{C}$ & 3.00 & $<30$ & -389 & 24.9 & $1.06 \mathrm{E}-09$ & Const. Load & 1.5 \\
\hline 316 & Base & SA & $\mathrm{C} 21$ & C21-C & 3.00 & $<30$ & -483 & 22.9 & $7.85 \mathrm{E}-10$ & Const. Load & -5.0 \\
\hline 316 & Base & SA & $\mathrm{C} 21$ & C21-C & 3.00 & $<30$ & -487 & 20.2 & $3.12 \mathrm{E}-10$ & Const. Load & -15.6 \\
\hline 316 & Base & SA & $\mathrm{C} 21$ & $\mathrm{C} 21-\mathrm{C}$ & 3.00 & $<30$ & $(-485)$ & 22.1 & $1.80 \mathrm{E}-09$ & Const. Load & -4.5 \\
\hline
\end{tabular}


Table 14. (Contd.)

\begin{tabular}{|c|c|c|c|c|c|c|c|c|c|c|c|}
\hline $\begin{array}{l}\text { Steel } \\
\text { Type }\end{array}$ & Materiala $^{a}$ & Condition $^{\mathrm{b}}$ & Heat ${ }^{c}$ & $\begin{array}{c}\text { Spec. } \\
\text { ID }\end{array}$ & $\begin{array}{c}\text { Dose, } \\
\text { dpa }\end{array}$ & $\begin{array}{l}\mathrm{DO}, \\
\mathrm{ppb}\end{array}$ & $\begin{array}{c}\text { ECP, } \\
\mathrm{mV}(\mathrm{SHE})\end{array}$ & $\begin{array}{c}\mathrm{K}_{\max }, \\
\mathrm{MPa} \mathrm{m}^{1 / 2} \\
\end{array}$ & $\begin{array}{c}\mathrm{CGR}, \mathrm{e} \\
\mathrm{m} / \mathrm{s}\end{array}$ & Waveform & $\begin{array}{c}\mathrm{K}_{\text {max }}- \\
\mathrm{K}_{\text {allowed }} \\
\text { f } \%\end{array}$ \\
\hline 304 & Base & Sens. & 10285 & $85-3 \mathrm{TT}$ & 2.16 & 500 & $(230)$ & 15.7 & $1.97 \mathrm{E}-10$ & Const. Load & -21.4 \\
\hline $304 \mathrm{~L}$ & SAW HAZ & AW & GG & GG5B-A & 0.00 & 500 & $(230)$ & 21.1 & $6.01 \mathrm{E}-11$ & Periodic Unload & 14.4 \\
\hline $304 \mathrm{~L}$ & SAW HAZ & AW & GG & GG5B-A & 0.00 & 500 & $(230)$ & 26.5 & $1.72 \mathrm{E}-10$ & Periodic Unload & 44.8 \\
\hline $304 \mathrm{~L}$ & SAW HAZ & AW & GG & GG5B-A & 0.00 & 500 & (230) & 26.9 & $1.55 \mathrm{E}-10$ & Periodic Unload & 47.6 \\
\hline $304 \mathrm{~L}$ & SAW HAZ & $\mathrm{AW}+\mathrm{TT}$ & GG & GG3B-A-TT & 0.00 & 400 & 68 & 16.4 & $4.34 \mathrm{E}-11$ & Periodic Unload & -12.4 \\
\hline 304 & SMAW HAZ & AW & 10285 & 85-YA & 0.00 & 300 & $(230)$ & 19.7 & $1.50 \mathrm{E}-12$ & Const. Load & -5.6 \\
\hline 304 & SMAW HAZ & $\mathrm{AW}+\mathrm{TT}$ & 10285 & $85-3 \mathrm{~A}-\mathrm{TT}$ & 0.00 & 600 & 106 & 21.2 & $6.60 \mathrm{E}-10$ & Periodic Unload & 4.7 \\
\hline 304 & SMAW HAZ & $\mathrm{AW}+\mathrm{TT}$ & 10285 & 85-3A-TT & 0.00 & 45 & -633 & 21.4 & $9.13 \mathrm{E}-11$ & Periodic Unload & 6.8 \\
\hline 304 & SMAW HAZ & $\mathrm{AW}+\mathrm{TT}$ & 10285 & $85-3 \mathrm{~A}-\mathrm{TT}$ & 0.00 & $<40$ & -627 & 25.0 & $4.29 \mathrm{E}-11$ & Periodic Unload & 25.4 \\
\hline $304 \mathrm{~L}$ & SAW HAZ & AW & GG & GG5T-B & 0.75 & 350 & 176 & 14.7 & $\begin{array}{c}6.75 \mathrm{E}-10 \\
(7.11 \mathrm{E}-10)\end{array}$ & Trapezoidal & -44.8 \\
\hline $304 \mathrm{~L}$ & SAW HAZ & AW & GG & GG5T-B & 0.75 & 350 & 204 & 15.0 & 4.24E-10 & Const. Load & -43.3 \\
\hline $304 \mathrm{~L}$ & SAW HAZ & AW & GG & GG5T-B & 0.75 & 350 & 202 & 15.2 & $\begin{array}{c}5.62 \mathrm{E}-10 \\
(5.72 \mathrm{E}-10)\end{array}$ & Trapezoidal & -41.7 \\
\hline $304 \mathrm{~L}$ & SAW HAZ & AW & GG & GG5T-B & 0.75 & $<50$ & -285 & 14.9 & $1.50 \mathrm{E}-12$ & Trapezoidal & -42.7 \\
\hline $304 \mathrm{~L}$ & SAW HAZ & AW & GG & GG6T-A & 2.16 & 600 & 223 & 16.0 & 4.17E-10 & Const. Load & -21.0 \\
\hline $304 \mathrm{~L}$ & SAW HAZ & AW & GG & GG6T-A & 2.16 & 600 & 224 & 13.6 & $4.04 \mathrm{E}-10$ & Const. Load & -32.3 \\
\hline $304 \mathrm{~L}$ & SAW HAZ & AW & GG & GG6T-A & 2.16 & 600 & 218 & 10.9 & $5.78 \mathrm{E}-10$ & Const. Load & -45.1 \\
\hline $304 \mathrm{~L}$ & SAW HAZ & AW & GG & GG6T-A & 2.16 & 600 & 218 & 7.0 & $1.66 \mathrm{E}-10$ & Const. Load & -64.6 \\
\hline 304 & SMAW HAZ & $\mathrm{AW}$ & 10285 & $85-7 \mathrm{~A}$ & 0.75 & 500 & 212 & 18.6 & $\begin{array}{c}9.51 \mathrm{E}-10 \\
(1.10 \mathrm{E}-09)\end{array}$ & Trapezoidal & -35.4 \\
\hline 304 & SMAW HAZ & AW & 10285 & $85-7 \mathrm{~A}$ & 0.75 & 500 & 214 & 19.4 & $9.46 \mathrm{E}-10$ & Const. Load & -31.5 \\
\hline 304 & SMAW HAZ & AW & 10285 & $85-7 \mathrm{~A}$ & 0.75 & $<50$ & -252 & 19.8 & $1.55 \mathrm{E}-11$ & Const. Load & -29.2 \\
\hline 304 & SMAW HAZ & AW & 10285 & 85-XA & 2.16 & 500 & 235 & 13.9 & $1.98 \mathrm{E}-10$ & Const. Load & -30.3 \\
\hline 304 & SMAW HAZ & AW & 10285 & 85-XA & 2.16 & 500 & 210 & 14.0 & $2.61 \mathrm{E}-10$ & Const. Load & -29.3 \\
\hline 304 & SMAW HAZ & $\mathrm{AW}+\mathrm{TT}$ & 10285 & 85-1A-TT & 0.75 & 250 & 182 & 16.6 & $\begin{array}{c}2.55 \mathrm{E}-10 \\
(2.34 \mathrm{E}-10)\end{array}$ & Trapezoidal & -43.6 \\
\hline 304 & SMAW HAZ & $\mathrm{AW}+\mathrm{TT}$ & 10285 & 85-1A-TT & 0.75 & 250 & 188 & 16.7 & $\begin{array}{c}1.74 \mathrm{E}-10 \\
(1.64 \mathrm{E}-10)\end{array}$ & Trapezoidal & -43.3 \\
\hline 304 & SMAW HAZ & $\mathrm{AW}+\mathrm{TT}$ & 10285 & 85-1A-TT & 0.75 & 250 & 185 & 18.7 & $\begin{array}{c}2.78 \mathrm{E}-10 \\
(2.67 \mathrm{E}-10)\end{array}$ & Trapezoidal & -35.7 \\
\hline 304 & SMAW HAZ & $\mathrm{AW}+\mathrm{TT}$ & 10285 & 85-1A-TT & 0.75 & $<30$ & -258 & 19.3 & $\begin{array}{c}5.73 \mathrm{E}-11 \\
(3.89 \mathrm{E}-11)\end{array}$ & Trapezoidal & -33.4 \\
\hline CF-8M & Cast SS & Aged & 75 & 75-11TT & 2.46 & 600 & 217 & 17.5 & $1.24 \mathrm{E}-10$ & Const. Load & -22.7 \\
\hline CF-8M & Cast SS & Aged & 75 & 75-11TM & 2.46 & 600 & 226 & 14.7 & $4.27 \mathrm{E}-10$ & Const. Load & -35.0 \\
\hline CF-8M & Cast SS & Aged & 75 & 75-11TM & 2.46 & 600 & 220 & 10.7 & $1.72 \mathrm{E}-10$ & Const. Load & -52.5 \\
\hline CF-8M & Cast SS & Aged & 75 & 75-11TM & 2.46 & 600 & 209 & 7.6 & $2.84 \mathrm{E}-11$ & Const. Load & -66.2 \\
\hline
\end{tabular}

\subsubsection{Solution-Annealed Materials}

The constant-load CGRs obtained at ANL for irradiated Types 304L, 316L, and 316 SS in highand low-DO environments (corresponding to NWC and HWC BWR environments, respectively) are shown in Fig. 50; symbols shown with a "+" represent loading conditions that did not satisfy the specimen K/size criterion (Eq. 8) based on effective yield stress (defined as the average of the irradiated and nonirradiated yield stresses). In the NWC BWR environment (Fig. 50a), the CGRs for SSs irradiated to $\approx 0.45 \mathrm{dpa}$ are comparable to the CGRs predicted by the NUREG-0313 disposition curve (Eq. 16) for nonirradiated, sensitized SSs in water with 8 ppm DO. For SSs irradiated to $\approx 1.35$ or 3.0 dpa, the CGRs are comparable and a factor of $\approx 6$ higher than the NUREG-0313 disposition curve. ${ }^{60}$

The results in Fig. 50 also indicate a benefit from a low-DO environment. In general, for the materials and irradiation conditions investigated in the present study, the CGRs decreased more than an 


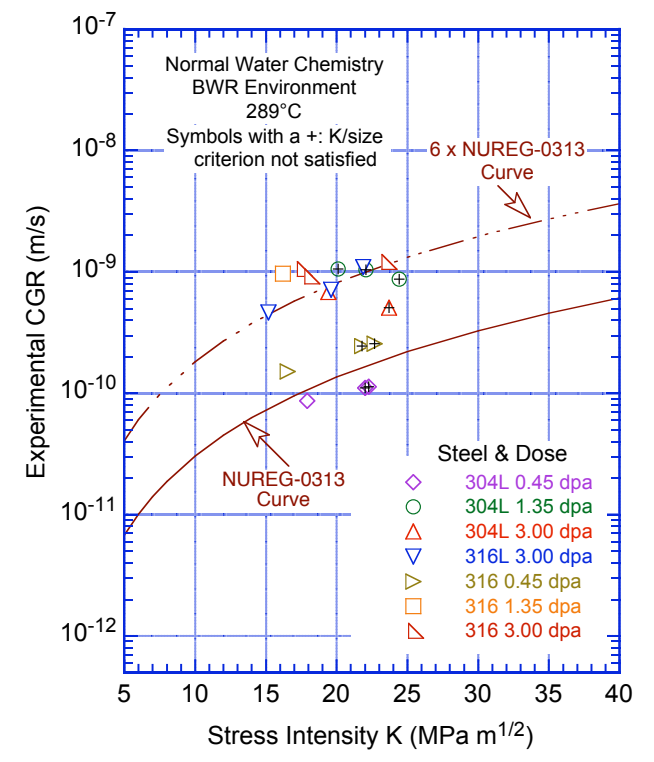

(a)

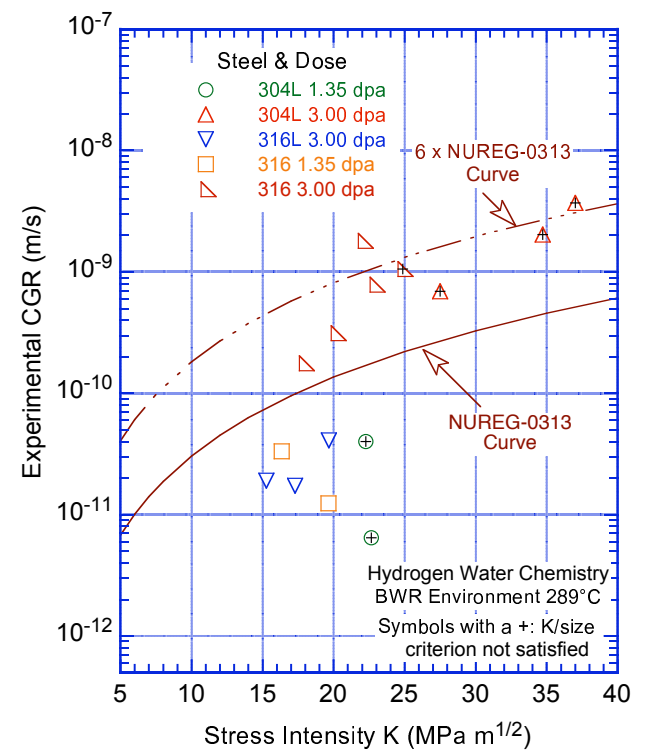

(b)

Figure 50. CGR data under constant load with periodic partial unloads for irradiated austenitic SSs in high-purity water at $289^{\circ} \mathrm{C}$.

order of magnitude when the DO level was decreased from $\approx 350$ to $<30 \mathrm{ppb}$ (i.e., by changing from NWC to HWC environments). A few specimens showed a different behavior. For example, no benefit of lowDO environment was observed for Heat C3 of Type 304L SS irradiated to 3.0 dpa (triangles in Fig. 50). It is not clear whether this behavior is genuine or caused by loss of specimen constraint because of the high applied load. For Heat $\mathrm{C} 3$, the applied $\mathrm{K}_{\max }$ of $\approx 25 \mathrm{MPa} \mathrm{m}^{1 / 2}$ (i.e., during periods 6 and 7 , see Table A.3) was $53 \%$ greater than the value allowed by the $\mathrm{K} /$ size criterion. Under these conditions, the CGR remained constant at $\approx 5 \times 10^{-10} \mathrm{~m} / \mathrm{s}$ for $\approx 370 \mathrm{~h}$ when the DO level was decreased from $\approx 300$ to $<20 \mathrm{ppb}$. Later during test periods 8 and 9 (see Table A.3), both the CGR and applied $\mathrm{K}_{\max }$ increased rapidly. As discussed in Section 4.1.5, the behavior during periods 8 and 9 can clearly be attributed to a loss of specimen constraint; the fracture plane deviated from the normal plane, and the crack propagated at an angle of $45^{\circ}$ to the original fracture plane.

Similarly, a benefit of HWC was not observed for Heat $\mathrm{C} 21$ at $\mathrm{K}_{\max } \approx 25 \mathrm{MPa} \mathrm{m}{ }^{1 / 2}$. For Heat $\mathrm{C} 21$, all applied $\mathrm{K}_{\max }$ values, except during period 8, satisfied the $\mathrm{K} /$ size criterion. The experimental CGRs for Heat C21 in BWR environments are plotted in Fig. 51; the numbers next to the data points represent test period. The CGR decreased by a factor of $\approx 8$ when DO was decreased at $\approx 19 \mathrm{MPa} \mathrm{m}{ }^{1 / 2}$ (during test periods 4 and 5, see Table 6). It did not change when DO was decreased at $\approx 25 \mathrm{MPa} \mathrm{m}^{1 / 2}$ (during test periods 7 and 8 ). The applied $\mathrm{K}_{\max }$ during test periods 4 and 5 was $\approx 7 \%$ higher than the value allowed by the $\mathrm{K} /$ size criterion. It was decreased to a value that satisfied the $\mathrm{K} /$ size criterion (test period 9a); no significant change in CGR was observed even after $\approx 0.15-\mathrm{mm}$ crack advance. The applied $\mathrm{K}_{\max }$ was then decreased further to $21.4 \mathrm{MPa} \mathrm{m}^{1 / 2}$; after an $\approx 50$-h period of slightly lower CGR (test period $9 \mathrm{~b}$ ), the growth rate increased back to the value observed earlier during test periods 7 and 8 . It is not clear whether this behavior should be attributed to a loss of constraint, or whether there are other threshold conditions, e.g., exceeding a threshold CGR, under which a low DO offers no benefit, and the temporary decrease of the rates was due to the relatively large decrease in $\mathrm{K}_{\max }(\approx 12 \%)$. The possible effect of specimen size is discussed further in Section 4.1.5.

Metallographic examination of the fracture surfaces indicated a predominantly IG fracture under constant load. Micrographs of the fracture surface of Specimen C3-C are presented in Section 4.1.5. 


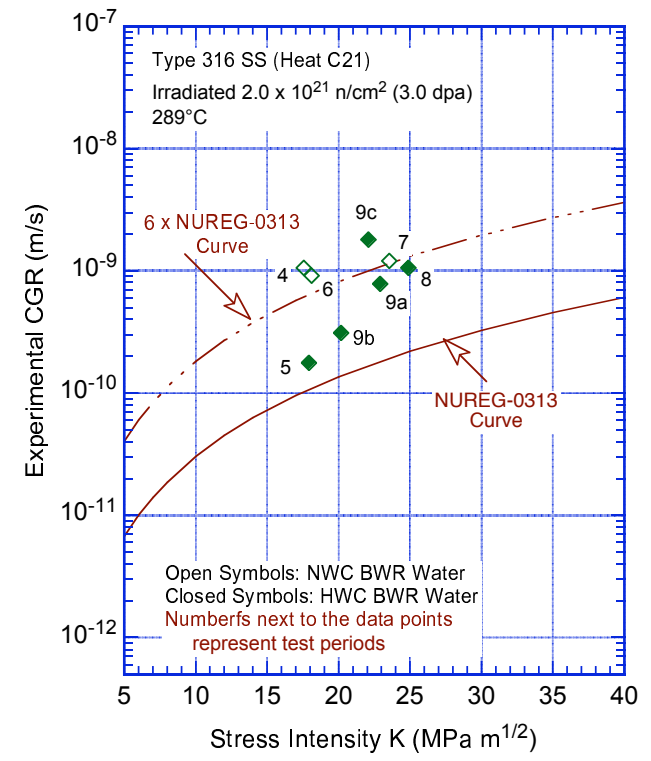

Figure 51.

Crack growth rates under constant load for irradiated Heat C21 of Type 316 SS in NWC and HWC BWR environments at $289^{\circ} \mathrm{C}$.

\subsubsection{Stainless Steel Weld HAZ Materials}

Figure 52 shows the constant-load CGRs obtained at ANL for nonirradiated and irradiated Types 304L and 304 SS weld HAZ materials and sensitized Type 304 SS. These materials were tested in high-DO and low-DO environments at $289^{\circ} \mathrm{C}$. For nonirradiated materials (Fig. 52a), because of relatively low values of flow stress, the applied $\mathrm{K}_{\max }$ for all materials, except thermally treated Type 304L SA weld HAZ (squares in Fig. 52a), did not satisfy the K/size criterion of ASTM E-1681. In addition, for the Type 304 SS SMA weld HAZ specimen (right angle triangles in Fig. 52a), the fracture plane was not normal to the stress axis but at an angle of $45^{\circ}$ to the stress axis, the CGR for this specimen is not included in Fig. 52a.

For nonirradiated GG Type 304L SA weld HAZ, although the data did not meet the K/size criterion of ASTM E-1681, the as-welded (triangles in Fig. 52a) and as-welded plus thermally-treated (squares in Fig. 52a) materials have comparable CGRs. For both conditions, the CGRs are a factor of $\approx 2$ lower than the NUREG-0313 curve for nonirradiated, sensitized SSs in water with 8 ppm DO. ${ }^{60}$ These results are in good agreement with the CGR of $1 \times 10^{-10} \mathrm{~m} / \mathrm{s}$ obtained by Andresen et al. ${ }^{51}$ for the GG Type 304L weld $\mathrm{HAZ}$ in high-DO water $(2000 \mathrm{ppb} \mathrm{DO})$ at $288^{\circ} \mathrm{C}$ and $\mathrm{K}_{\max }=27.4 \mathrm{MPa} \mathrm{m}^{1 / 2}$.

Irradiation increased the CGRs of all SS weld HAZ materials; the loading conditions for all data shown in Fig. 52b satisfied the K/size criterion (Eq. 8) based on the effective yield stress. The CGRs of HAZ specimens irradiated to $\approx 0.75$ and $2.16 \mathrm{dpa}$ are comparable and are a factor of 3-10 higher than those predicted by the NUREG-0313 disposition curve. Reducing the corrosion potential of the environment was beneficial for all materials that were tested in the HWC BWR environment. The growth rates of irradiated or nonirradiated Type 304 weld HAZ decreased by an order of magnitude or more when the DO was decreased from $\approx 350 \mathrm{ppb}$ to $<30 \mathrm{ppb}$ (Fig. 52).

An IG fracture occurred for both nonirradiated and irradiated Type 304 SMA weld HAZ materials. However, the fracture morphology of nonirradiated Type 304L SA weld HAZ material was primarily TG with a well-defined river pattern. A TG fracture morphology is unusual in SS weld HAZ. The presence of residual strain in the material typically promotes IG crack growth even in nonsensitized SS. ${ }^{49-52}$ An IG fracture is always observed in cold-worked SSs. 


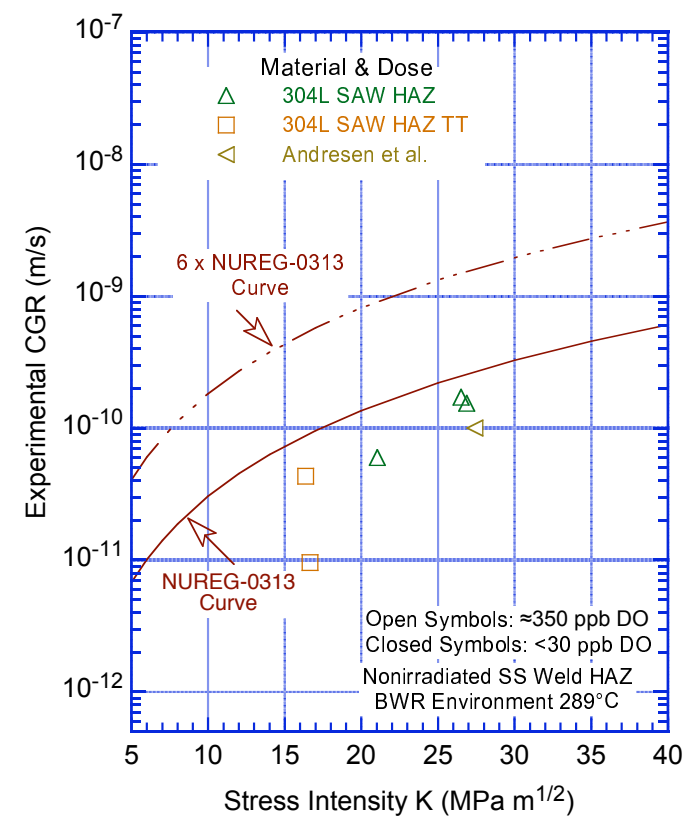

(a)

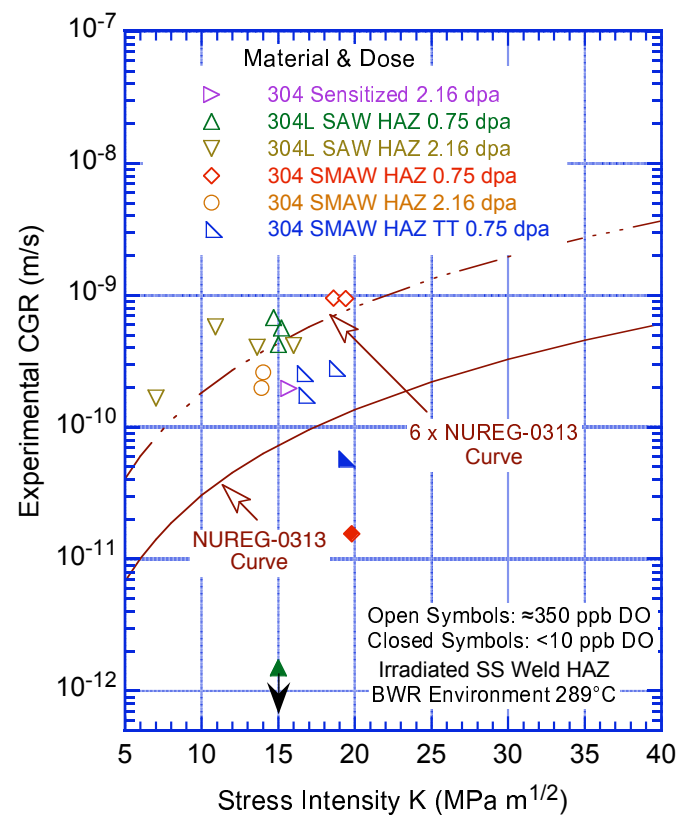

(b)

Figure 52. CGR under constant load with periodic partial unloads for (a) nonirradiated and (b) irradiated SS weld HAZ specimens in high-purity water at $289^{\circ} \mathrm{C}$.

\subsubsection{Cast Austenitic Stainless Steel}

Figure 53 gives the constant-load CGRs for two irradiated specimens of CF-8M cast SS in the NWC BWR environment. The specimens were aged for $10,000 \mathrm{~h}$ at $400^{\circ} \mathrm{C}$ before irradiation. Although the measured CGRs for the two specimens differ significantly, the results are comparable to the data obtained on solution-annealed SSs and weld HAZ materials irradiated to similar dose levels. The CGRs are a factor of 2-6 above the values predicted by the NUREG-0313 curve for nonirradiated austenitic SSs. ${ }^{60}$

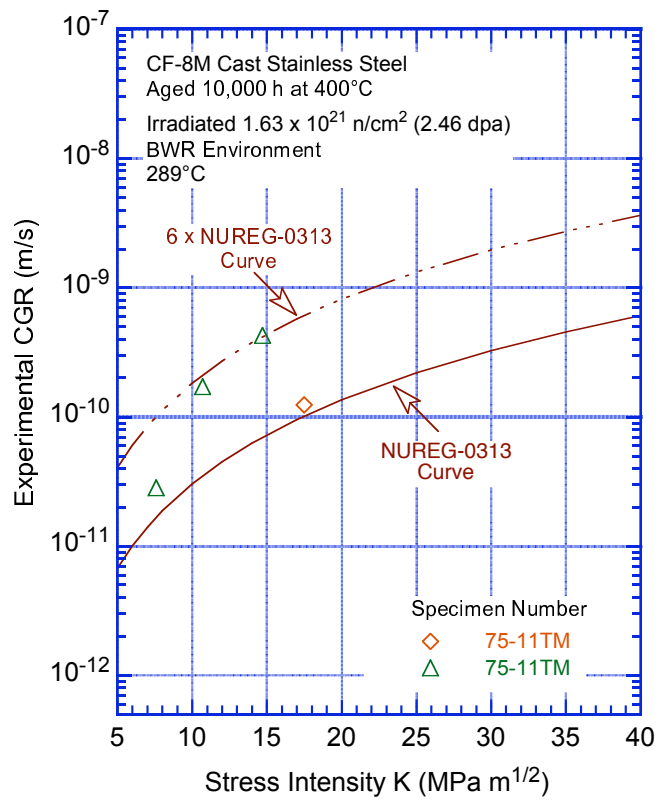

Figure 53.

CGR under constant load for thermally aged and irradiated CF-8M cast stainless steel specimens in BWR environment at $289^{\circ} \mathrm{C}$. 


\subsubsection{Comparison with CGR Data in the Literature}

Figure 54 shows the constant-load CGR data obtained in the present study for NWC and HWC BWR environments with austenitic SSs and weld HAZ materials irradiated to 0.75-2.2 dpa, along with the data available in the literature ${ }^{63}$ for purposes of comparison. Most of the CGRs are a factor of 3-10 greater than the values predicted by the NUREG-0313 curve for nonirradiated sensitized SSs in water with 8 ppm DO. ${ }^{60}$ For the same irradiation level, the CGRs for weld HAZ materials are higher than those for solution-annealed SSs. Also, at these irradiation dose levels a beneficial effect of reducing the corrosion potential by changing from the NWC to HWC BWR environment is observed for all materials; the growth rates in low-DO water are more than a factor of 10 lower than in high-DO water.

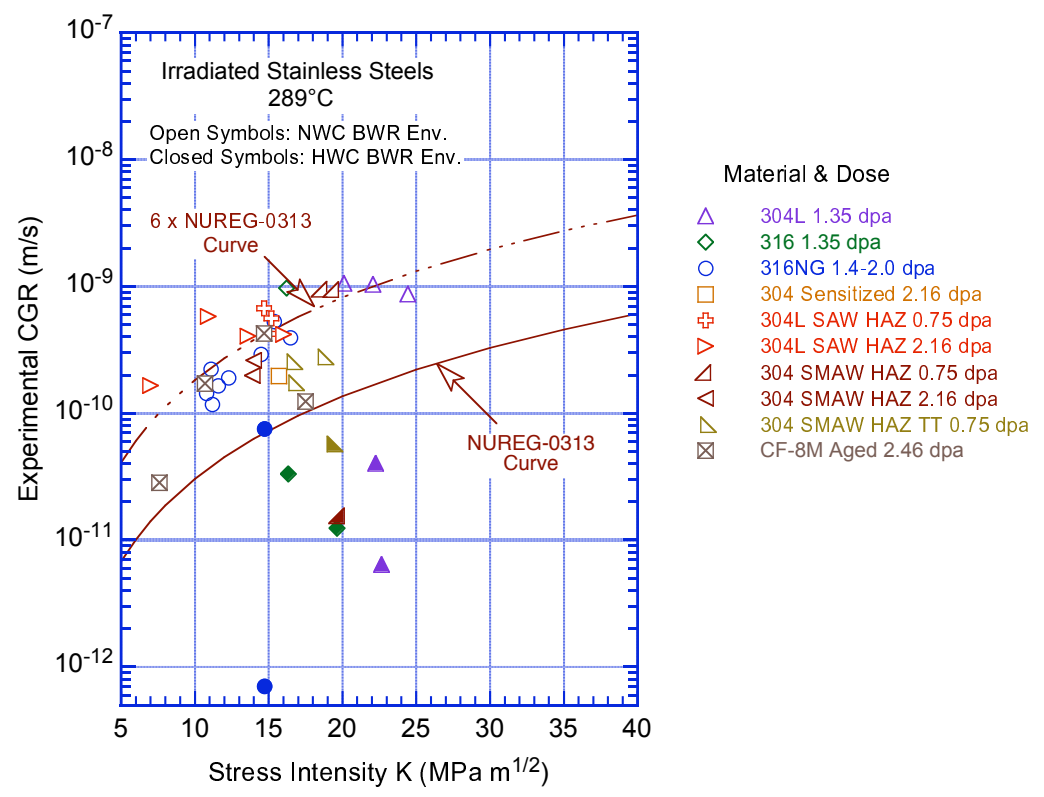

Figure 54. CGR under constant load in NWC and HWC BWR environments at $289^{\circ} \mathrm{C}$ for austenitic stainless steels irradiated to 0.75-2.2 dpa (Ref. 63, present study).

The constant-load CGRs obtained in the present study in NWC and HWC BWR environments on austenitic SSs and weld HAZ materials irradiated to 3.0-4.0 dpa are compared with the data available in the literature 56,63 in Fig. 55. At these irradiation doses, the CGRs in NWC BWR environment are a factor of 3-10 greater than the values predicted by the NUREG-0313 curve for nonirradiated SSs. There is no apparent increase in CGR over the growth rates for material with lower fluence levels, although the number of heats of material is limited. A beneficial effect of low DO was not observed in these tests at higher values of $\mathrm{K}$ (greater than $20 \mathrm{MPa} \mathrm{m}{ }^{1 / 2}$ ). The Type $304 \mathrm{SS}$ irradiated to $4.0 \mathrm{dpa}$ and tested at $\approx 17 \mathrm{MPa} \mathrm{m}{ }^{1 / 2}$ (open and closed right angle triangles in Fig. 55) showed reduced CGRs in low-DO water. HWC was not beneficial at higher loads (e.g., $\mathrm{K}_{\max } \geq 30 \mathrm{MPa} \mathrm{m}^{1 / 2}$ ); however, the specimen $\mathrm{K} /$ size criterion was not satisfied at these loads in either NWC or HWC environments. The specimen $\mathrm{K} /$ size criterion was also not satisfied for the Type 304L SS irradiated to $3.0 \mathrm{dpa}$ (closed triangles) tested in the $\mathrm{HWC}$ environment at $\mathrm{K}_{\max } \geq 35 \mathrm{MPa} \mathrm{m}^{1 / 2}$. Possible effects of specimen $\mathrm{K} /$ size criterion are discussed in the next section.

The constant-load CGR data from the present study and available in the literature 57,63 on austenitic SSs irradiated to $\approx 0.45 \mathrm{dpa}$ and $13.0 \mathrm{dpa}$ are presented in Figs. $56 \mathrm{a}$ and $\mathrm{b}$, respectively. At $0.45 \mathrm{dpa}$, the CGRs are in good agreement with the values predicted by the NUREG-0313 curve for nonirradiated SSs. ${ }^{60}$ The CGRs for SSs irradiated to 13 dpa show a strong dependence on $\mathrm{K}$ at less than $15 \mathrm{MPa} \mathrm{m}^{1 / 2}$ 


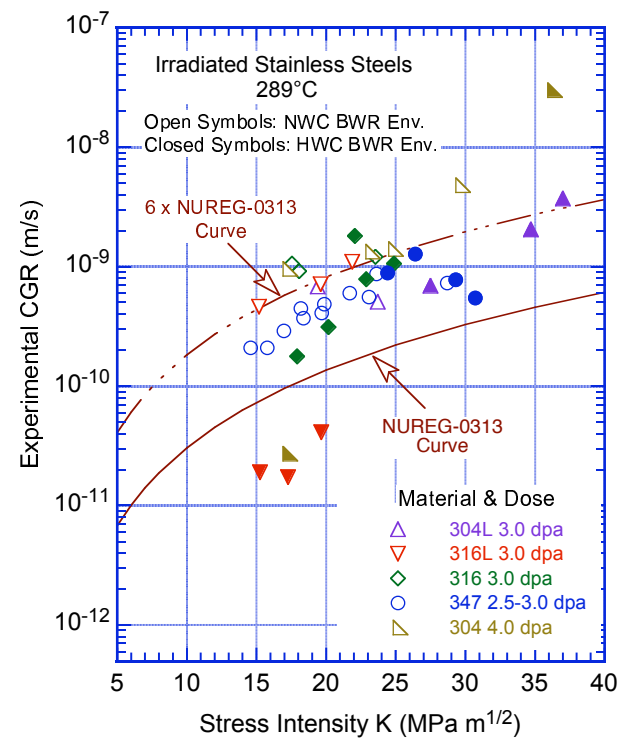

Figure 55.

CGR under constant load in NWC and HWC BWR environments at $289^{\circ} \mathrm{C}$ for austenitic stainless steels irradiated to $3.0-4.0 \mathrm{dpa}$ (Refs. 56, 63, and present study).

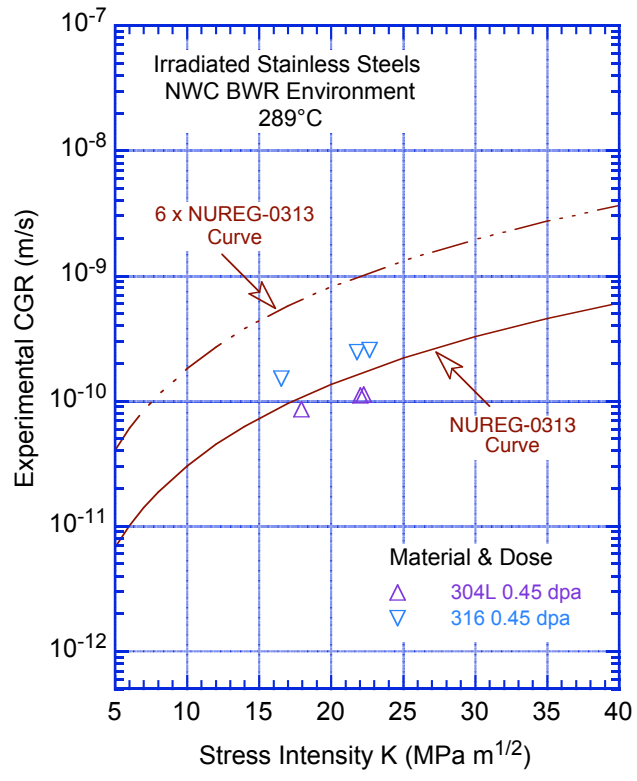

(a)

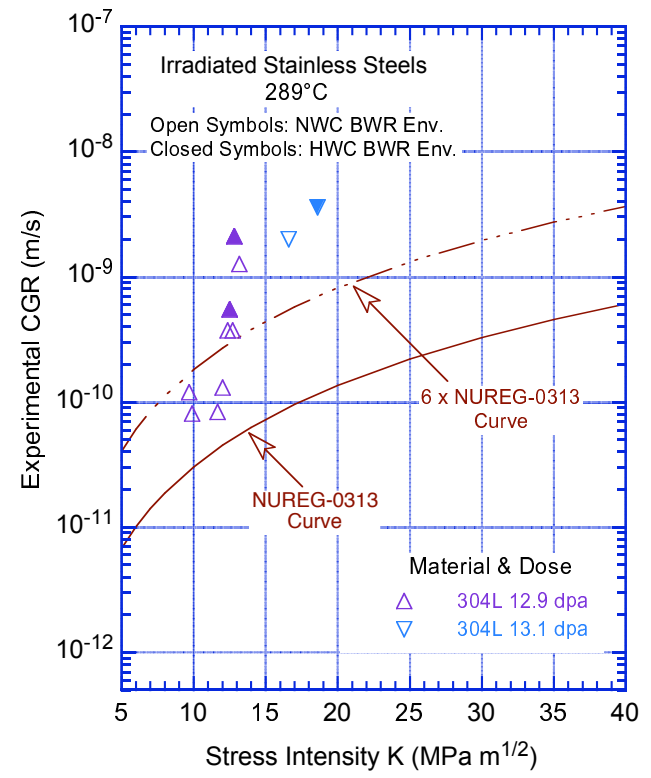

(b)

Figure 56. CGR under constant load in BWR environment at $289^{\circ} \mathrm{C}$ for austenitic stainless steels irradiated to (a) $<0.5 \mathrm{dpa}$ (present study) and (b) $\approx 13.0 \mathrm{dpa}$ (Refs. 57,63 ).

and are up to a factor of 30 higher than the NUREG-0313 curve. A beneficial effect of low corrosion potential was not observed for steels irradiated to $13.0 \mathrm{dpa}$.

The constant-load CGRs of austenitic SSs irradiated to 1.0-2.5, 3.0-4.0, and $13 \mathrm{dpa}$ are plotted as a function of the steel ECP in Fig. 57. The effect of reduced corrosion potential on the CGRs of irradiated SSs is seen clearly in these figures. Decreasing the corrosion potential has a beneficial effect on growth rates for all steels irradiated to 1.0-2.5 dpa. A beneficial effect has been observed in a few cases for steels irradiated to 3.0-4.0 dpa, and in no cases for steels irradiated to $13 \mathrm{dpa}$. The fact that for some materials a beneficial effect is seen at one $\mathrm{K}$ level, but not at another higher $\mathrm{K}$ level, could be an indication of a loss of constraint or some kind of threshold phenomenon. The failure to see a benefit even at relatively low $\mathrm{K}$ levels at $\approx 13$ dpa could be due to fluence effects on the constraint criteria or on the threshold effect. 


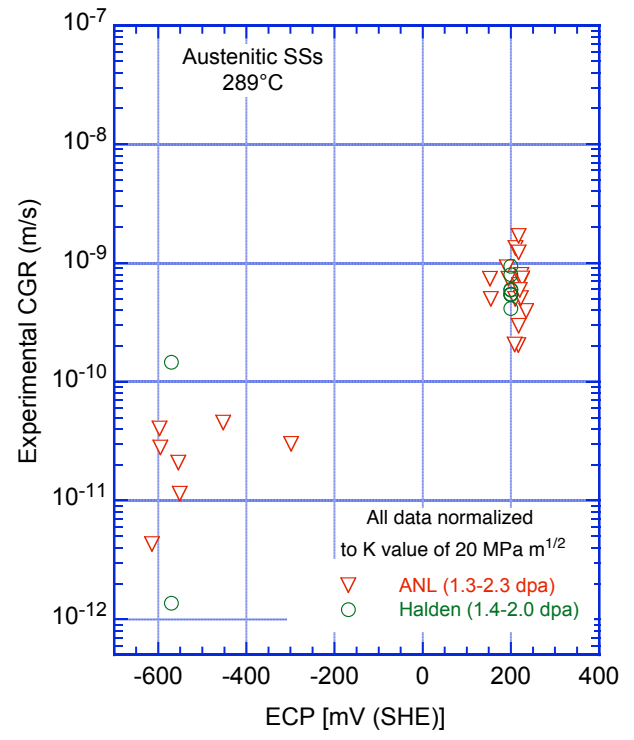

(a)

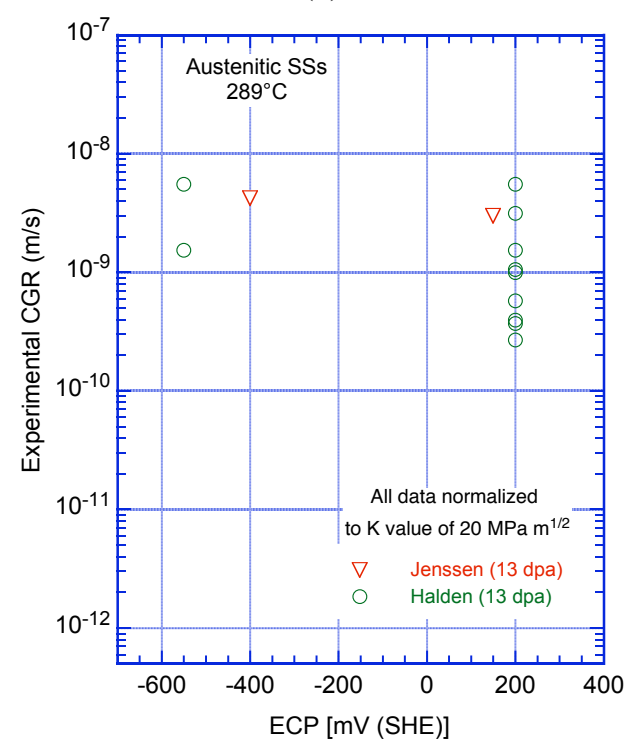

(c)

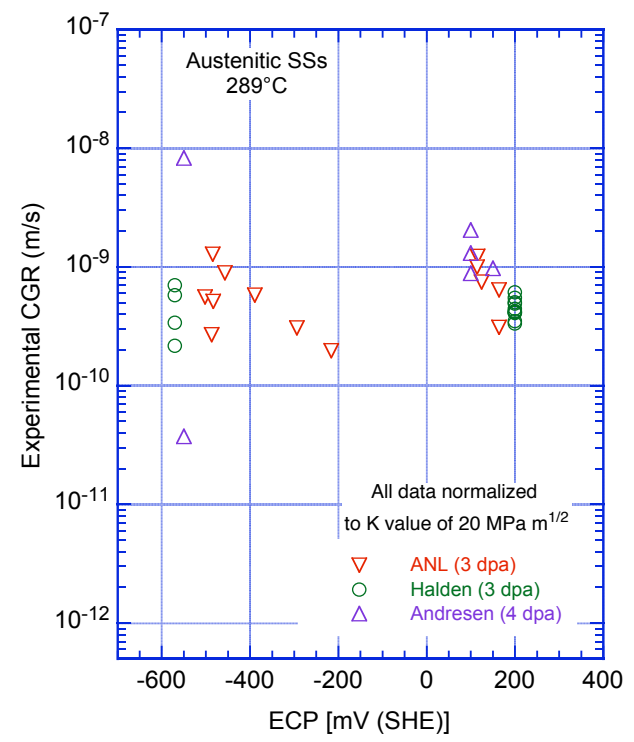

(b)

Figure 57.

CGR under constant load in NWC and HWC BWR environments for austenitic stainless steels irradiated to (a) 1.0-2.5 dpa, (b) 3.0-4.0 $\mathrm{dpa}$, and (c) $13 \mathrm{dpa}$, plotted as a function of the steel ECP.

\subsubsection{Specimen K/Size Criterion}

For austenitic SSs irradiated to neutron dose levels of 3.0-4.0 dpa, there are only a few cases in the existing CGR data on irradiated austenitic SSs in simulated BWR environments that show a significant decrease in CGR when the DO is decreased from $\approx 300 \mathrm{ppb}$ to $<30 \mathrm{ppb}$. There are data for SSs irradiated to 3.0 dpa that show no decrease in CGR when the DO level is reduced to levels corresponding to HWC. However, it is not clear whether the loading conditions for these tests had satisfied the $\mathrm{K} /$ size validity criterion, because the appropriate criterion for $\mathrm{K}_{\max }$ for highly irradiated materials is not clearly defined. The K/size validity issue is not well treated by the ASTM standards because irradiated materials undergo local (and macroscopic) work softening as the first dislocations sweep out the point defect damage (creating localized "channels" of high dislocation activity). Andresen has suggested a criterion based on the effective yield stress [defined as $\left(\sigma_{\text {eff }}=\sigma_{\text {yirr }}+\sigma_{\text {ynonirr }}\right) / 2$ ] ${ }^{56}$ Jenssen et al. ${ }^{57}$ proposed an even more restrictive criterion $\sigma_{\text {eff }}=\left(\sigma_{\text {yirr }}+\sigma_{\text {ynonirr }}\right) / 3$ for highly irradiated materials. Jenssen et al. ${ }^{57}$ have 
performed an FEM analysis of the plastic strain in front of a crack tip in a work softening material to help support their argument, but provide no criteria to determine how much plastic strain or what size plastic zone is acceptable, e.g, by comparison with plastic zones in specimens for nonirradiated materials that can be demonstrated to have sufficient constraint empirically by testing different specimen sizes. There appears to be an implicit assumption that if lowering the DO is effective at one $\mathrm{K}$ level and is not effective at another, higher $\mathrm{K}$ level, then it must be due to a loss of constraint without due consideration of the possibility of other effects. In this section, the current data are reviewed specifically in terms of the insight they can provide on the choice of specimen size criterion.

The experimental CGRs obtained in the present study under loading conditions that exceed the $\mathrm{K} /$ size criterion proposed by Andresen are shown in Fig. 58; the numbers next to the data points represent the value (in percentages) by which the applied $\mathrm{K}_{\max }$ exceeded the allowed value. The significant results from these tests are summarized as follows:

(a) For all tests in high-DO water, although the applied $\mathrm{K}_{\max }$ exceeds the value allowed by the $\mathrm{K} /$ size criterion by up to $\approx 60 \%$, the CGRs measured from these tests are consistent with the results from tests that meet the criterion. Also, the $\mathrm{K}$ dependence for these tests is consistent with that observed for valid tests (e.g., the data yield an exponent of $\approx 2.1$ ). Furthermore, in high-DO water, the CGR did not increase during the test period (for up to $200 \mathrm{~h}$ ). Typically, the CGR increases rapidly when the applied load exceeds the specimen $\mathrm{K} /$ size criterion; for a 1/2-T CT specimen of Type $304 \mathrm{SS}$ irradiated to $4.0 \mathrm{dpa}$, the CGR increased by a factor 5 in a period of $40 \mathrm{~h}$ in high-DO water at $288^{\circ} \mathrm{C}$ and $\mathrm{K}_{\max }$ of 29-34 MPa m ${ }^{1 / 2} .56$

(b) The two data points obtained in low-DO environment on Types 304L and 316 SS irradiated to $3.0 \mathrm{dpa}$ and tested at $25-30 \mathrm{MPa} \mathrm{m}^{1 / 2}$ (solid triangle and right-angle triangle in Fig. 58) did not show the expected decrease in CGR when the DO level in the environment was decreased. It is argued that because the expected decrease in growth rate is not observed for these tests, the loading conditions must have exceeded the specimen K/size criterion. For Type 304L SS irradiated to 3.0 dpa, Fig. 59 shows the change in crack length and $\mathrm{K}_{\max }$ with time during periods $6(\approx 200$ $311 \mathrm{~h})$ and $7(\approx 400-540 \mathrm{~h})$. The results indicate no change in CGR during these test periods. A similar behavior was also observed for Type $316 \mathrm{SS}$. It is not clear whether this behavior should be

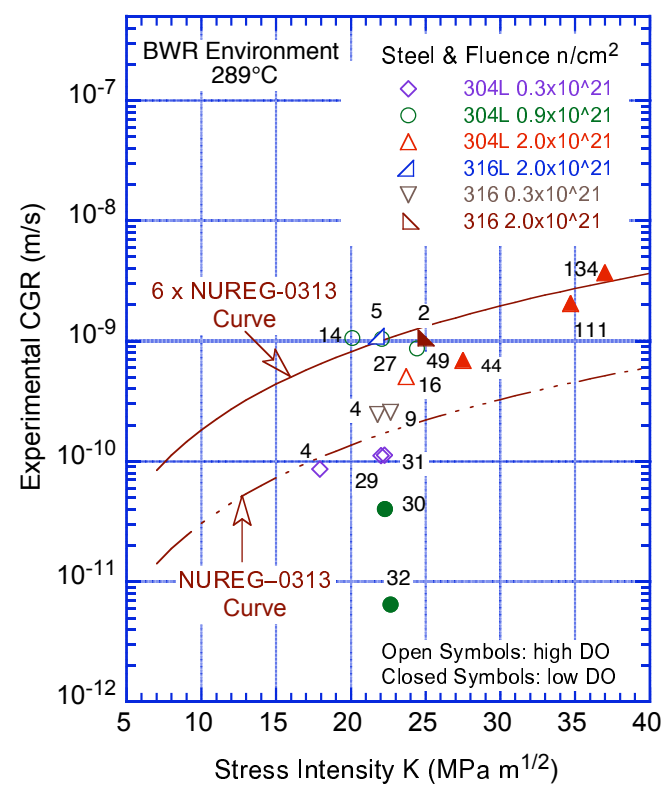

Figure 58.

Experimental CGRs for irradiated austenitic stainless steels obtained in high- and low-DO BWR environments under loading conditions that exceeded the $\mathrm{K} /$ size criterion. The numbers next to the data points represent the difference (percentages) between the applied and allowed $\mathrm{K}_{\max }$. 
attributed to loss of specimen constraint. In both cases, the loading condition seems to have had no effect on growth rates until the DO level in the environment was decreased. If specimen constraint had been lost, the growth rate should have rapidly increased in high-DO water.

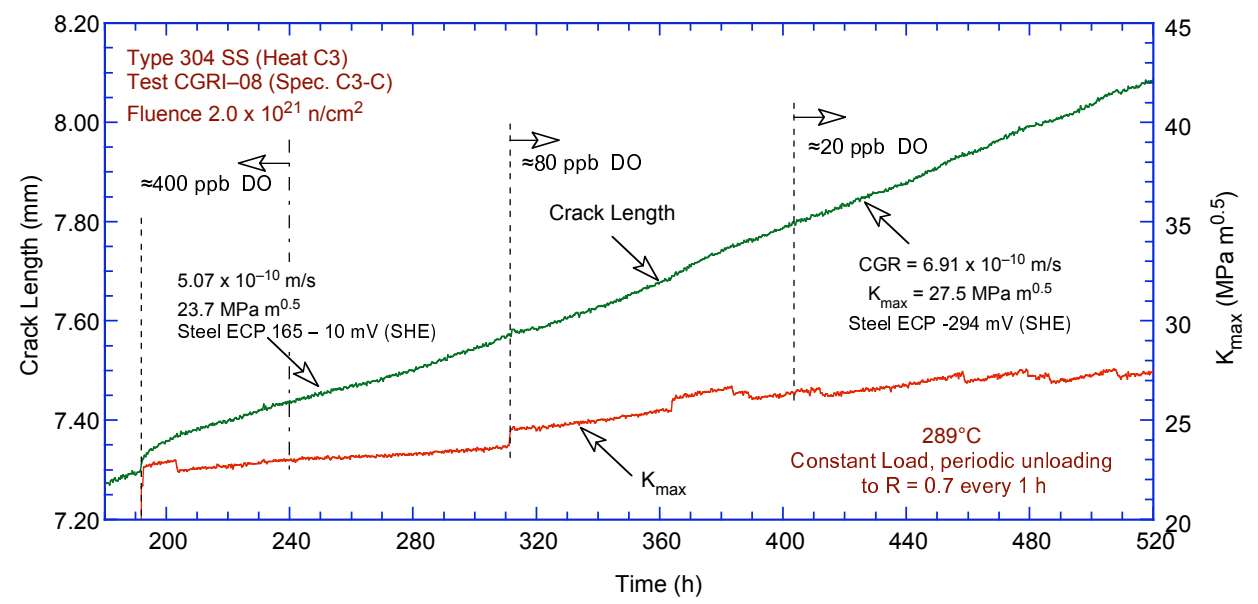

Figure 59. Crack length and $K_{\max }$ vs. time for Type 304L SS Specimen C3-C in highpurity water at $289^{\circ} \mathrm{C}$ during test periods 6 and 7 .

(c) The specimen constraints were lost for the irradiated Type 304L SS in low-DO water during test periods 8 and 9 at $\mathrm{K}_{\max }>35 \mathrm{MPa} \mathrm{m}^{1 / 2}$ (solid triangles in Fig. 58), as evidenced by unusually high growth rates. This behavior has been verified by fractographic examination of the specimen; under these loading conditions, the crack propagation was away from the normal plane.

A loss of specimen constraint can also influence the fracture mode and morphology. For example, if the thickness criterion is exceeded, the crack plane is typically out-of-normal near the edges of the specimen, and if the specimen ligament criterion is exceeded, the crack propagates away from the normal plane at an angle of $45^{\circ}$. The fracture surface of Specimen $\mathrm{C} 3-\mathrm{C}$ was examined to investigate any change in fracture morphology and/or change in the fracture plane. Figure 60 shows a side view of a 1-mm-wide slice of the fracture surface (along the entire crack advance) cut from Specimen C3-C. The fracture surface is towards the top, in a plane perpendicular to the picture. (Although precautions were taken to ensure that the specimen was square to the movement of the EDM wire, the cuts were not always straight; the bottom surface of this slice has an uneven cut.) The profile of the fracture surface indicates that the fracture plane is relatively straight and normal to the stress axis for the initial $\approx 3.5-\mathrm{mm}$ crack extension. The DO level was decreased from $\approx 400$ to $20 \mathrm{ppb}$ at $\approx 1.7$-mm crack extension, which is equivalent to the middle of the relatively straight crack extension. The fracture plane is out-of-normal for crack extensions greater than $3.5 \mathrm{~mm}$. A secondary crack that propagated at an angle of $\approx 45^{\circ}$ to the original fracture plane is also observed. This region corresponds to the crack advance during test period 9 (see Table A.3).

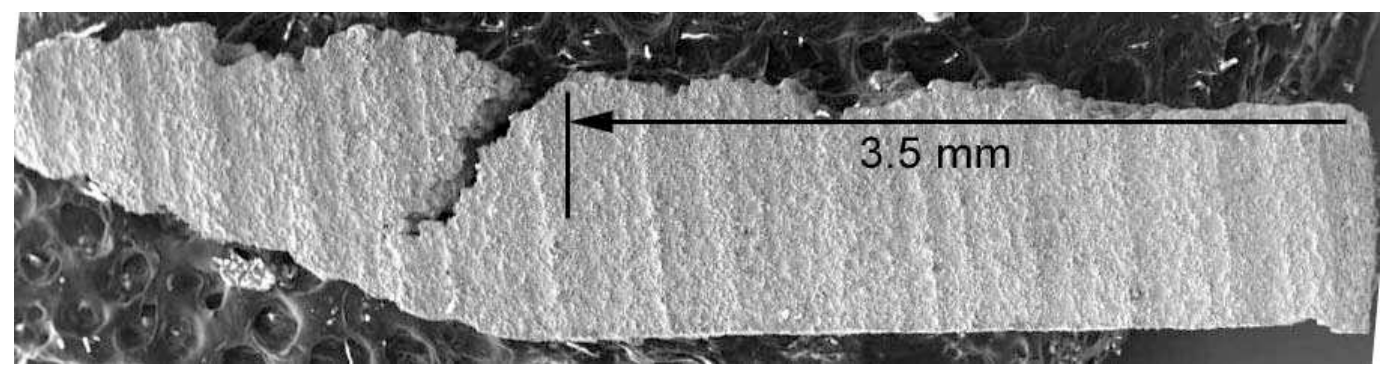

Figure 60. Side view of the first slice cut from Type 304L SS Specimen C3-C. 
These results indicate that the specimen ligament criterion, most likely, was exceeded during test periods 8 and 9; also, the CGRs during these periods were unusually high (Fig. 58).

A collage of images taken from the entire crack extension for the first slice is shown in Fig. 61a, and high-magnification photomicrographs of the surface at locations 2 and 1 are shown in Figs. $61 \mathrm{~b}$ and $\mathrm{c}$, respectively. After the initial $\approx 0.6$-mm-long TG crack, the fracture morphology for the specimen is completely IG for the remainder of the test. The transition from a TG to IG fracture appears to have occurred at $\approx 80 \mathrm{~h}$ during test period 2 . Locations 1 and 2 represent regions near the end of TG fracture and start of the IG fracture, respectively.

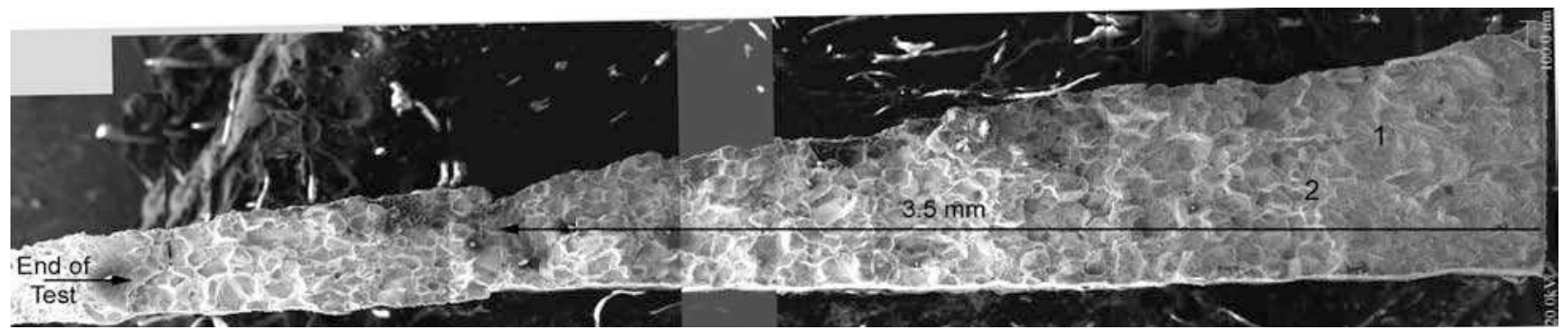

(a)

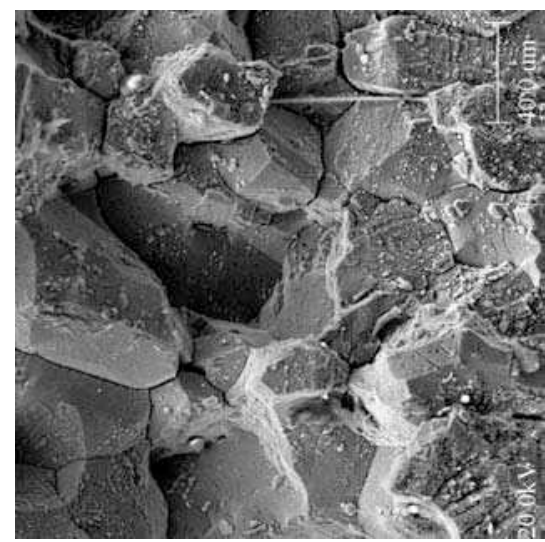

(b)

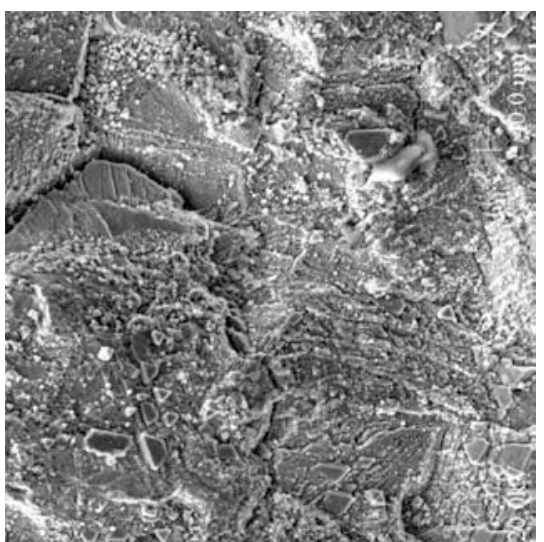

(c)

Figure 61. (a) A photograph of the entire crack extension for the first slice of Type 304L SS Specimen C3-C and high-magnification micrographs of the surface at locations 2 (b) and 1 (c).

A composite photograph of the fracture surface of a second slice from Specimen C3-C is shown in Fig. 62a, and high-magnification photomicrographs of the fracture surface at locations D, C, B, and A are shown in Figs. 62b, c, d, and e, respectively. These locations represent the fracture morphology during test periods 2, 3, 6, and 7, respectively. After the initial TG fracture during test period 1, the fracture morphology during all other test periods is completely IG. No fractographic indication of a change in fracture mode due to a loss in constraint is evident at the $\approx 1.6$ - $\mathrm{mm}$ crack extension. Also, the fracture morphology for test periods 6 and 7 (Figs. $62 \mathrm{~d}$ and e) is the same.

Although the proposed specimen size criterion of Eq. 8 was not met for Specimen $\mathrm{C} 3-\mathrm{C}$ at the time when the DO level was decreased from $\approx 400$ to $20 \mathrm{ppb}$ (i.e., at $\approx 1.6-\mathrm{mm}$ crack extension between test periods 6 and 7), there was no fractographic indication of a loss in constraint in the specimen (i.e., the fracture morphology did not change, and the fracture plane was straight and normal to the stress axis). Furthermore, the growth rate was constant in high-DO water during test period 6; if the applied $\mathrm{K}_{\max }$ exceeded the specimen size criterion during periods 6 and 7, the CGR would be expected to have increased during test period 6. 


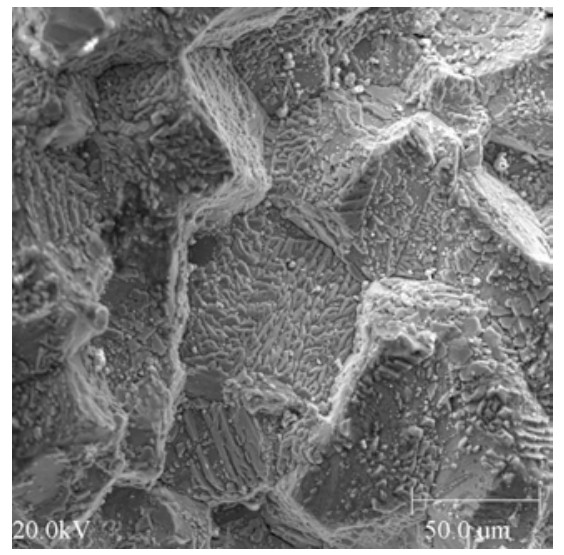

b

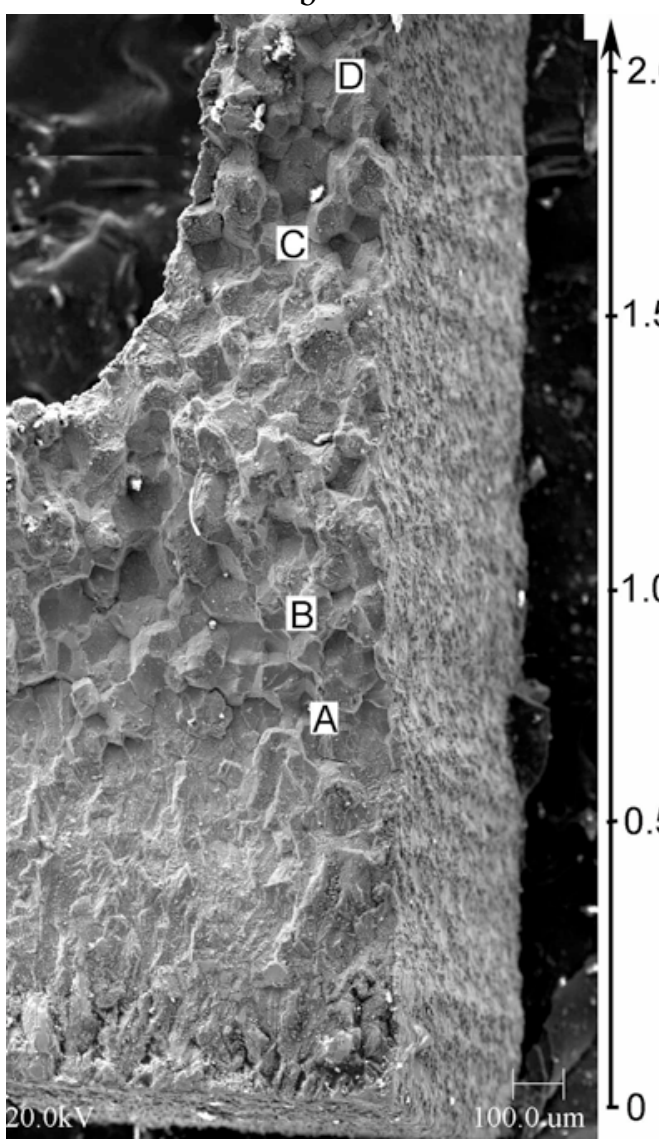

a

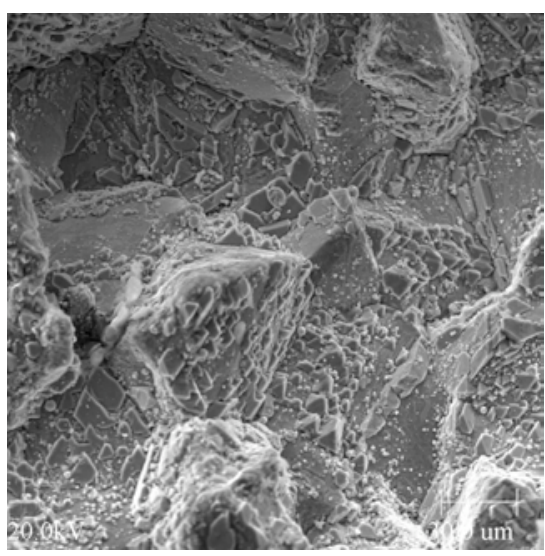

c

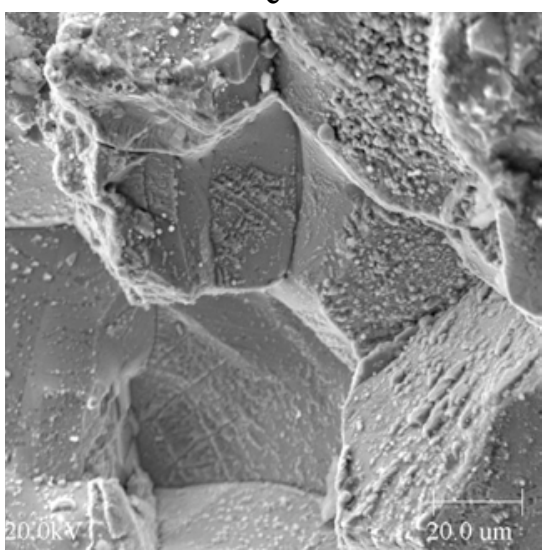

$\mathrm{d}$

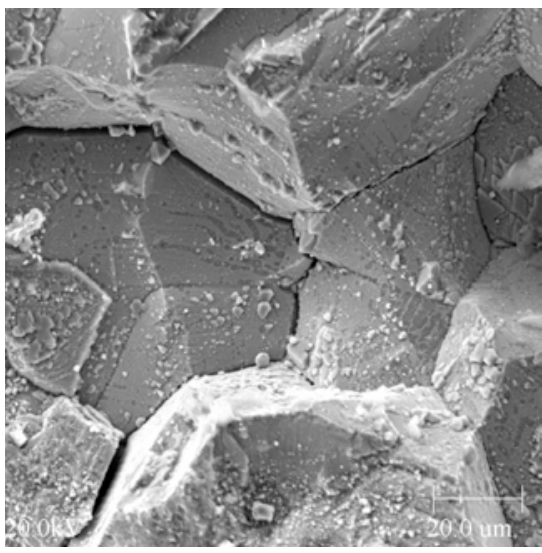

Figure 62. (a) Photograph of the fracture surface of the second slice of Type 304L SS Specimen C3-C and high-magnification micrographs of the surface at locations (b) D, (c) C, (d) B, and (e) A.

The proposed $\mathrm{K} /$ size criterion is based on a weighted average of the irradiated and nonirradiated yield stress. The usual ASTM criteria consider only the yield strength of the actual material being tested. Pettersson* has presented three arguments against the proposed criterion.

*Kjell Pettersson, Matsafe AB, private communication, Nov. 2006, "Some Aspects of Specimen Size Validity and Crack Tip Strain Rate.” 
Firstly, Pettersson suggests that the strain softening in irradiated austenitic SSs is rarely more than $10-15 \%$. This behavior is clearly demonstrated in the engineering stress vs. strain curves shown in Fig. 63 for Type $304 \mathrm{SS}$ irradiated to $3.0 \mathrm{dpa}$ in the Halden reactor at $288^{\circ} \mathrm{C}$ and tested in air at 289 and $325^{\circ} \mathrm{C} .{ }^{53}$ Secondly, in most of the plastic zone the plastic strains are so low that the material never passes the maximum tensile stress, so that it is effectively not a strain-softening material. Thirdly, finite element analyses indicate that the difference between the strain distributions ahead of an advancing crack, in a strain-hardening material versus a strain-softening material, is marginal (Fig. 64). These calculations do not support the suggestion that the nonirradiated yield strength should be involved in any calculations of specimen sizes for obtaining valid data.
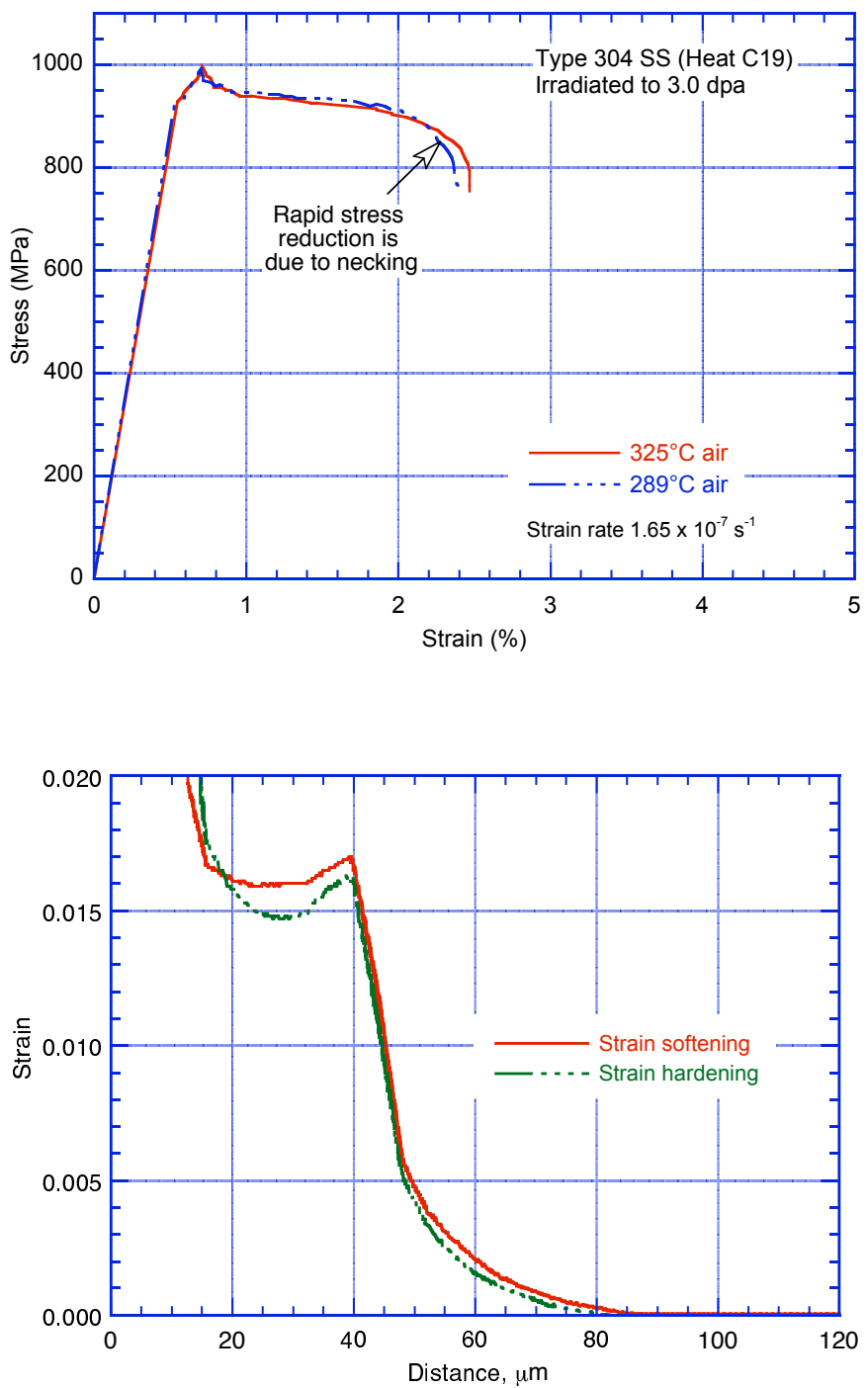

Figure 63.

Engineering stress vs. strain curve for Type 304 stainless steel irradiated to $3.0 \mathrm{dpa}$ and tested in air at 289 and $325^{\circ} \mathrm{C}$ (Ref. 53).
Figure 64.

Strain distribution of a moving crack in a strain-softening and a strain-hardening material.

The existing data for constant-load CGR in austenitic SSs irradiated up to 4.0 dpa indicate that all examples of unusually high growth rates, or lack of a benefit of HWC on growth rate, occur at a CGR of approximately $1 \times 10^{-9} \mathrm{~m} / \mathrm{s}$. This growth rate seems to be necessary and possibly is associated with the mechanism responsible for the high rates in low-DO environments. Such a dependence of environmental effects on the rate of production of fresh surface has been observed in the enhancement of CGRs of carbon and low-alloy steels in low-DO environments. 


\subsection{CGRs under Continuous Cycling}

The cyclic CGRs from the present study and those obtained earlier at ANL $^{27,54}$ are compiled in Table 15. The tests were conducted with either a triangular or slow/fast sawtooth waveform. The load ratio $\mathrm{R}$ was $\leq 0.3$ for the triangular waveform and 0.3-0.7 for the sawtooth waveform. The rise time and return time for each loading waveform are listed in the table, as well as the stress intensity factors. The CGRs (da/dt) were determined by using only the rise time for the fatigue cycle. The CGRs in air, under the same loading conditions, were determined from the correlations developed by James and Jones ${ }^{58}$ for solution-annealed SSs.

Table 15. The cyclic crack growth data in BWR environment at $289^{\circ} \mathrm{C}$.

\begin{tabular}{|c|c|c|c|c|c|c|c|c|c|c|c|c|c|}
\hline $\begin{array}{l}\text { Steel } \\
\text { Type } \\
\end{array}$ & Material $^{\mathrm{a}}$ & Condition ${ }^{b}$ & Heat ${ }^{c}$ & $\begin{array}{c}\text { Spec. } \\
\text { ID }\end{array}$ & $\begin{array}{c}\begin{array}{c}\text { Dose, } \\
\text { dpa }\end{array} \\
\end{array}$ & $\begin{array}{l}\mathrm{DO}, \\
\mathrm{ppb}\end{array}$ & $\begin{array}{c}\mathrm{ECP}, \mathrm{d} \\
\mathrm{mV}(\mathrm{SHE})\end{array}$ & $\begin{array}{c}\text { Rise } \\
\text { Time, } \mathrm{s}\end{array}$ & $\begin{array}{l}\text { Return } \\
\text { Time, } \mathrm{s} \\
\end{array}$ & $\begin{array}{c}\mathrm{K}_{\max } \\
\mathrm{MPa} \mathrm{m}^{1 / 2}\end{array}$ & $\begin{array}{c}\Delta \mathrm{K}, \\
\mathrm{MPa} \mathrm{m}^{1 / 2}\end{array}$ & $\begin{array}{c}\mathrm{CGR}, \\
\mathrm{m} / \mathrm{s}\end{array}$ & $\begin{array}{c}\mathrm{CGR}_{\text {air }}, \\
\mathrm{m} / \mathrm{s}\end{array}$ \\
\hline $304 \mathrm{~L}$ & Base & SA & $\mathrm{C} 3$ & C3-A & 0.45 & 300 & 166 & 0.5 & 0.5 & 14.0 & 9.8 & 8.37E-09 & $1.97 \mathrm{E}-08$ \\
\hline $304 \mathrm{~L}$ & Base & SA & $\mathrm{C} 3$ & C3-A & 0.45 & 300 & 171 & 0.5 & 0.5 & 15.0 & 10.5 & $1.48 \mathrm{E}-08$ & $2.51 \mathrm{E}-08$ \\
\hline $304 \mathrm{~L}$ & Base & SA & $\mathrm{C} 3$ & C3-A & 0.45 & 300 & 171 & 1 & 1 & 15.9 & 11.1 & $1.39 \mathrm{E}-08$ & $1.50 \mathrm{E}-08$ \\
\hline $304 \mathrm{~L}$ & Base & SA & $\mathrm{C} 3$ & C3-A & 0.45 & 300 & 171 & 30 & 4 & 16.0 & 11.2 & $1.33 \mathrm{E}-09$ & $5.17 \mathrm{E}-10$ \\
\hline $304 \mathrm{~L}$ & Base & SA & $\mathrm{C} 3$ & C3-A & 0.45 & 300 & 177 & 300 & 4 & 15.9 & 11.3 & $3.29 \mathrm{E}-10$ & $5.24 \mathrm{E}-11$ \\
\hline $304 \mathrm{~L}$ & Base & SA & $\mathrm{C} 3$ & C3-A & 0.45 & 300 & 173 & 300 & 4 & 15.7 & 8.2 & $4.75 \mathrm{E}-11$ & $2.17 \mathrm{E}-11$ \\
\hline $304 \mathrm{~L}$ & Base & SA & $\mathrm{C} 3$ & C3-A & 0.45 & 300 & 188 & 12 & 12 & 17.6 & 5.3 & $6.23 \mathrm{E}-11$ & $1.57 \mathrm{E}-10$ \\
\hline $304 \mathrm{~L}$ & Base & SA & $\mathrm{C} 3$ & C3-B & 1.35 & 300 & 147 & 0.5 & 0.5 & 18.7 & 15.0 & $4.51 \mathrm{E}-08$ & $7.07 \mathrm{E}-08$ \\
\hline $304 \mathrm{~L}$ & Base & SA & $\mathrm{C} 3$ & C3-B & 1.35 & 300 & 148 & 0.5 & 0.5 & 17.6 & 14.1 & 4.17E-08 & $5.83 \mathrm{E}-08$ \\
\hline $304 \mathrm{~L}$ & Base & SA & $\mathrm{C} 3$ & C3-B & 1.35 & 300 & (148) & 30 & 2 & 16.9 & 7.9 & $1.12 \mathrm{E}-10$ & $2.09 \mathrm{E}-10$ \\
\hline $304 \mathrm{~L}$ & Base & SA & $\mathrm{C} 3$ & C3-B & 1.35 & 300 & (148) & 0.5 & 0.5 & 17.9 & 14.3 & $3.41 \mathrm{E}-08$ & $6.12 \mathrm{E}-08$ \\
\hline $304 \mathrm{~L}$ & Base & SA & $\mathrm{C} 3$ & C3-B & 1.35 & 300 & 154 & 0.5 & 0.5 & 19.1 & 15.3 & $6.83 \mathrm{E}-08$ & $7.63 \mathrm{E}-08$ \\
\hline $304 \mathrm{~L}$ & Base & SA & $\mathrm{C} 3$ & C3-B & 1.35 & 300 & 189 & 60 & 2 & 19.0 & 9.3 & $1.75 \mathrm{E}-10$ & $1.72 \mathrm{E}-1 \mathrm{C}$ \\
\hline $304 \mathrm{~L}$ & Base & SA & $\mathrm{C} 3$ & C3-B & 1.35 & 300 & 187 & 300 & 2 & 19.8 & 5.9 & $6.38 \mathrm{E}-10$ & $9.26 \mathrm{E}-12$ \\
\hline $304 \mathrm{~L}$ & Base & SA & $\mathrm{C} 3$ & C3-B & 1.35 & $\approx 10$ & -607 & 300 & 2 & 22.1 & 6.6 & $8.56 \mathrm{E}-11$ & $1.33 \mathrm{E}-11$ \\
\hline $304 \mathrm{~L}$ & Base & SA & $\mathrm{C} 3$ & C3-B & 1.35 & $\approx 10$ & -609 & 300 & 2 & 22.5 & 6.8 & $3.37 \mathrm{E}-11$ & $1.42 \mathrm{E}-11$ \\
\hline $304 \mathrm{~L}$ & Base & SA & $\mathrm{C} 3$ & C3-B & 1.35 & $\approx 10$ & -620 & 1000 & 2 & 23.0 & 6.9 & $1.20 \mathrm{E}-11$ & $4.59 \mathrm{E}-12$ \\
\hline $304 \mathrm{~L}$ & Base & SA & $\mathrm{C} 3$ & C3-B & 1.35 & $\approx 10$ & -624 & 30 & 2 & 22.9 & 6.9 & $5.17 \mathrm{E}-11$ & $1.49 \mathrm{E}-10$ \\
\hline $304 \mathrm{~L}$ & Base & SA & $\mathrm{C} 3$ & C3-B & 1.35 & $\approx 10$ & -617 & 300 & 2 & 23.1 & 6.9 & $1.55 \mathrm{E}-11$ & $1.54 \mathrm{E}-11$ \\
\hline $304 \mathrm{~L}$ & Base & SA & $\mathrm{C} 3$ & C3-B & 1.35 & 250 & 151 & 1000 & 2 & 24.2 & 7.3 & $5.93 \mathrm{E}-10$ & $5.38 \mathrm{E}-12$ \\
\hline $304 \mathrm{~L}$ & Base & SA & $\mathrm{C} 3$ & C3-C & 3.00 & 300 & 164 & 2 & 2 & 17.9 & 13.2 & $2.00 \mathrm{E}-08$ & $1.27 \mathrm{E}-08$ \\
\hline $304 \mathrm{~L}$ & Base & SA & $\mathrm{C} 3$ & C3-C & 3.00 & 300 & 155 & 30 & 2 & 18.4 & 8.7 & $2.22 \mathrm{E}-09$ & $2.77 \mathrm{E}-10$ \\
\hline $304 \mathrm{~L}$ & Base & SA & $\mathrm{C} 3$ & $\mathrm{C} 3-\mathrm{C}$ & 3.00 & 300 & 167 & 300 & 2 & 18.8 & 5.6 & $1.73 \mathrm{E}-09$ & $7.83 \mathrm{E}-12$ \\
\hline $304 \mathrm{~L}$ & Base & SA & $\mathrm{C} 3$ & C3-C & 3.00 & 300 & 164 & 1000 & 2 & 19.2 & 6.0 & $1.25 \mathrm{E}-09$ & $2.79 \mathrm{E}-12$ \\
\hline $316 \mathrm{~L}$ & Base & SA & $\mathrm{C} 16$ & C16-B & 3.00 & 250 & (144) & 1 & 1 & 14.3 & 9.8 & $1.75 \mathrm{E}-08$ & $9.96 \mathrm{E}-0 \varsigma$ \\
\hline $316 \mathrm{~L}$ & Base & SA & $\mathrm{C} 16$ & C16-B & 3.00 & 250 & 144 & 2 & 2 & 14.0 & 9.8 & 7.54E-09 & 4.94E-0 \\
\hline $316 \mathrm{~L}$ & Base & SA & $\mathrm{C} 16$ & C16-B & 3.00 & 250 & 144 & 2 & 2 & 14.2 & 9.8 & 8.94E-09 & $5.00 \mathrm{E}-0$ \\
\hline $316 \mathrm{~L}$ & Base & SA & $\mathrm{C} 16$ & C16-B & 3.00 & 250 & 148 & 12 & 2 & 14.6 & 6.4 & 4.94E-10 & $2.67 \mathrm{E}-10$ \\
\hline $316 \mathrm{~L}$ & Base & SA & $\mathrm{C} 16$ & C16-B & 3.00 & 250 & 147 & 30 & 2 & 14.8 & 4.0 & $8.65 \mathrm{E}-10$ & $2.54 \mathrm{E}-11$ \\
\hline $316 \mathrm{~L}$ & Base & SA & $\mathrm{C} 16$ & C16-B & 3.00 & 250 & 151 & 300 & 2 & 15.0 & 4.4 & $8.16 \mathrm{E}-10$ & $3.34 \mathrm{E}-12$ \\
\hline $316 \mathrm{~L}$ & Base & SA & $\mathrm{C} 16$ & C16-B & 3.00 & 250 & 153 & 1,000 & 12 & 15.0 & 4.5 & 7.33E-10 & $1.12 \mathrm{E}-12$ \\
\hline $316 \mathrm{~L}$ & Base & SA & $\mathrm{C} 16$ & C16-B & 3.00 & $<30$ & -410 & 1,000 & 12 & 15.1 & 4.5 & $2.76 \mathrm{E}-11$ & $1.15 \mathrm{E}-12$ \\
\hline $316 \mathrm{~L}$ & Base & SA & $\mathrm{C} 16$ & C16-B & 3.00 & $<30$ & -449 & 30 & 2 & 15.2 & 4.1 & $6.07 \mathrm{E}-11$ & $2.79 \mathrm{E}-11$ \\
\hline $316 \mathrm{~L}$ & Base & SA & $\mathrm{C} 16$ & C16-B & 3.00 & $<30$ & -502 & 30 & 2 & 17.3 & 5.2 & $2.51 \mathrm{E}-10$ & $5.92 \mathrm{E}-11$ \\
\hline $316 \mathrm{~L}$ & Base & SA & $\mathrm{C} 16$ & C16-B & 3.00 & $<30$ & -545 & 1,000 & 12 & 17.2 & 5.3 & $3.59 \mathrm{E}-11$ & $1.95 \mathrm{E}-12$ \\
\hline 316 & Base & SA & $\mathrm{C} 21$ & C21-A & 0.45 & 350 & $(105)$ & 0.5 & 0.5 & 15.5 & 10.1 & $1.10 \mathrm{E}-08$ & $2.30 \mathrm{E}-08$ \\
\hline 316 & Base & SA & $\mathrm{C} 21$ & C21-A & 0.45 & 350 & 103 & 5 & 5 & 15.7 & 10.3 & $5.69 \mathrm{E}-09$ & $2.47 \mathrm{E}-0$ \\
\hline 316 & Base & SA & $\mathrm{C} 21$ & C21-A & 0.45 & 350 & 116 & 30 & 4 & 16.0 & 7.9 & $1.33 \mathrm{E}-09$ & $1.98 \mathrm{E}-10$ \\
\hline 316 & Base & SA & $\mathrm{C} 21$ & C21-A & 0.45 & 350 & $(160)$ & 300 & 12 & 16.1 & 7.6 & $3.82 \mathrm{E}-10$ & $1.78 \mathrm{E}-11$ \\
\hline 316 & Base & SA & $\mathrm{C} 21$ & C21-A & 0.45 & 350 & (160) & 300 & 12 & 16.2 & 5.0 & $1.10 \mathrm{E}-10$ & $5.28 \mathrm{E}-12$ \\
\hline 316 & Base & SA & $\mathrm{C} 21$ & $\mathrm{C} 21-\mathrm{A}$ & 0.45 & 350 & (160) & 1,000 & 12 & 16.3 & 4.9 & $5.84 \mathrm{E}-11$ & $1.45 \mathrm{E}-12$ \\
\hline 316 & Base & SA & $\mathrm{C} 21$ & C21-B & 1.35 & 350 & (180) & 0.5 & 0.5 & 15.9 & 10.6 & 2.63E-08 & $2.70 \mathrm{E}-08$ \\
\hline 316 & Base & SA & $\mathrm{C} 21$ & C21-B & 1.35 & 350 & 185 & 300 & 12 & 16.0 & 8.0 & $5.85 \mathrm{E}-10$ & $2.10 \mathrm{E}-11$ \\
\hline 316 & Base & SA & $\mathrm{C} 21$ & C21-B & 1.35 & 350 & 191 & 300 & 12 & 16.3 & 4.7 & $5.40 \mathrm{E}-10$ & $4.39 \mathrm{E}-12$ \\
\hline 316 & Base & SA & $\mathrm{C} 21$ & $\mathrm{C} 21-\mathrm{B}$ & 1.35 & 350 & 204 & 1000 & 12 & 16.2 & 4.9 & $4.91 \mathrm{E}-10$ & $1.44 \mathrm{E}-12$ \\
\hline
\end{tabular}


Table 15. (Contd.)

\begin{tabular}{|c|c|c|c|c|c|c|c|c|c|c|c|c|c|}
\hline $\begin{array}{l}\text { Steel } \\
\text { Type }\end{array}$ & Material $^{\mathrm{a}}$ & Condition $^{\mathrm{b}}$ & Heat ${ }^{c}$ & $\begin{array}{c}\text { Spec. } \\
\text { ID }\end{array}$ & $\begin{array}{c}\text { Dose, } \\
\text { dpa }\end{array}$ & $\begin{array}{l}\text { DO, } \\
\mathrm{ppb}\end{array}$ & $\begin{array}{c}\mathrm{ECP}, \mathrm{d} \\
\mathrm{mV} \text { (SHE) }\end{array}$ & $\begin{array}{c}\text { Rise } \\
\text { Time, } \mathrm{s}\end{array}$ & $\begin{array}{l}\text { Return } \\
\text { Time, s } \\
\end{array}$ & $\begin{array}{c}\mathrm{K}_{\max }, \\
\mathrm{MPa} \mathrm{m}^{1 / 2}\end{array}$ & $\begin{array}{c}\Delta \mathrm{K} \\
2 \mathrm{MPa} \mathrm{m}^{1 / 2} \\
\end{array}$ & $\begin{array}{c}\mathrm{CGR}, \\
\mathrm{m} / \mathrm{s}\end{array}$ & $\begin{array}{c}\mathrm{CGR}_{\text {air }}, \\
\mathrm{m} / \mathrm{s}\end{array}$ \\
\hline 316 & Base & SA & $\mathrm{C} 21$ & $\mathrm{C} 21-\mathrm{C}$ & 3.00 & 500 & $(230)$ & 0.5 & 0.5 & 15.5 & 10.4 & 4.87E-08 & $2.47 \mathrm{E}-08$ \\
\hline 316 & Base & SA & $\mathrm{C} 21$ & $\mathrm{C} 21-\mathrm{C}$ & 3.00 & 500 & $(230)$ & 30 & 5 & 15.7 & 7.5 & $3.12 \mathrm{E}-09$ & $1.74 \mathrm{E}-10$ \\
\hline 316 & Base & SA & $\mathrm{C} 21$ & C21-C & 3.00 & 500 & (230) & 300 & 4 & 16.5 & 8.1 & 2.84E-09 & $2.18 \mathrm{E}-11$ \\
\hline 316 & Base & SA & $\mathrm{C} 21$ & $\mathrm{C} 21-\mathrm{C}$ & 3.00 & 500 & (230) & 1000 & 12 & 17.0 & 4.9 & $3.22 \mathrm{E}-09$ & $1.53 \mathrm{E}-12$ \\
\hline 304 & Base & Sensitized & 10285 & $85-3 \mathrm{TT}$ & 2.16 & 500 & (220) & 0.33 & 0.5 & 14.9 & 8.7 & $1.64 \mathrm{E}-08$ & $2.28 \mathrm{E}-08$ \\
\hline 304 & Base & Sensitized & 10285 & $85-3 \mathrm{TT}$ & 2.16 & 500 & 218 & 142 & 4 & 15.3 & 4.0 & $1.02 \mathrm{E}-09$ & $5.37 \mathrm{E}-12$ \\
\hline 304 & Base & Sensitized & 10285 & $85-3 \mathrm{TT}$ & 2.16 & 500 & (220) & 13.7 & 4 & 15.4 & 3.8 & $3.16 \mathrm{E}-09$ & $5.03 \mathrm{E}-11$ \\
\hline 304 & Base & Sensitized & 10285 & $85-3 \mathrm{TT}$ & 2.16 & 500 & $(220)$ & 140 & 12 & 15.7 & 0.8 & $2.22 \mathrm{E}-10$ & $1.31 \mathrm{E}-13$ \\
\hline $304 \mathrm{~L}$ & SAW HAZ & As welded & GG shroud & GG5B-A & 0.00 & 580 & $(230)$ & 0.25 & 0.25 & 16.7 & 12.9 & 7.57E-08 & $8.98 \mathrm{E}-08$ \\
\hline $304 \mathrm{~L}$ & SAW HAZ & As welded & GG shroud & GG5B-A & 0.00 & 580 & $(230)$ & 0.25 & 0.25 & 15.0 & 11.5 & $3.42 \mathrm{E}-08$ & $6.18 \mathrm{E}-08$ \\
\hline $304 \mathrm{~L}$ & SAW HAZ & As welded & GG shroud & GG5B-A & 0.00 & 590 & $(230)$ & 7.5 & 7.5 & 14.2 & 11.0 & $3.59 \mathrm{E}-10$ & $1.75 \mathrm{E}-09$ \\
\hline $304 \mathrm{~L}$ & SAW HAZ & As welded & GG shroud & GG5B-A & 0.00 & 590 & (230) & 0.5 & 0.5 & 15.7 & 12.1 & $3.40 \mathrm{E}-08$ & $3.62 \mathrm{E}-08$ \\
\hline $304 \mathrm{~L}$ & SAW HAZ & As welded & GG shroud & GG5B-A & 0.00 & 485 & (220) & 30 & 2 & 15.5 & 7.4 & $5.85 \mathrm{E}-11$ & $1.65 \mathrm{E}-10$ \\
\hline $304 \mathrm{~L}$ & SAW HAZ & As welded & GG shroud & GG5B-A & 0.00 & 440 & (220) & 30 & 2 & 17.0 & 4.9 & $1.50 \mathrm{E}-12$ & $5.04 \mathrm{E}-11$ \\
\hline $304 \mathrm{~L}$ & SAW HAZ & As welded & GG shroud & GG5B-A & 0.00 & 450 & $(220)$ & 30 & 2 & 17.0 & 4.9 & $1.52 \mathrm{E}-11$ & $5.06 \mathrm{E}-11$ \\
\hline $304 \mathrm{~L}$ & SAW HAZ & As welded & GG shroud & GG5B-A & 0.00 & 465 & (220) & 30 & 2 & 20.6 & 5.8 & $3.15 \mathrm{E}-10$ & $8.49 \mathrm{E}-11$ \\
\hline $304 \mathrm{~L}$ & SAW HAZ & As welded & GG shroud & GG5B-A & 0.00 & 460 & (220) & 300 & 2 & 20.8 & 6.0 & $1.81 \mathrm{E}-10$ & $9.89 \mathrm{E}-12$ \\
\hline $304 \mathrm{~L}$ & SAW HAZ & As welded & GG shroud & GG5B-A & 0.00 & 500 & $(220)$ & 1,000 & 2 & 20.9 & 6.1 & $1.26 \mathrm{E}-10$ & $3.01 \mathrm{E}-12$ \\
\hline $304 \mathrm{~L}$ & SAW HAZ & As welded & GG shroud & GG5B-A & 0.00 & 500 & $(220)$ & 1000 & 2 & 27.4 & 7.9 & $3.18 \mathrm{E}-10$ & $7.32 \mathrm{E}-12$ \\
\hline $304 \mathrm{~L}$ & SAW HAZ & $\mathrm{AW}+\mathrm{TT}$ & GG shroud & GG3B-A-TT & 0.00 & 450 & (220) & 0.5 & 0.5 & 14.3 & 9.9 & $7.71 \mathrm{E}-09$ & $2.06 \mathrm{E}-08$ \\
\hline $304 \mathrm{~L}$ & SAW HAZ & $\mathrm{AW}+\mathrm{TT}$ & GG shroud & GG3B-A-TT & 0.00 & 450 & $(220)$ & 5 & 5 & 14.4 & 10.0 & $5.91 \mathrm{E}-09$ & $2.10 \mathrm{E}-09$ \\
\hline $304 \mathrm{~L}$ & SAW HAZ & $\mathrm{AW}+\mathrm{TT}$ & GG shroud & GG3B-A-TT & 0.00 & 450 & $(220)$ & 1 & 1 & 15.0 & 7.4 & $1.34 \mathrm{E}-09$ & 4.79E-09 \\
\hline $304 \mathrm{~L}$ & SAW HAZ & $\mathrm{AW}+\mathrm{TT}$ & GG shroud & GG3B-A-TT & 0.00 & 470 & (220) & 12 & 2 & 16.0 & 4.6 & $8.66 \mathrm{E}-10$ & $1.03 \mathrm{E}-10$ \\
\hline $304 \mathrm{~L}$ & SAW HAZ & $\mathrm{AW}+\mathrm{TT}$ & GG shroud & GG3B-A-TT & 0.00 & 470 & (220) & 12 & 2 & 16.3 & 4.7 & $2.50 \mathrm{E}-09$ & $1.10 \mathrm{E}-10$ \\
\hline $304 \mathrm{~L}$ & SAW HAZ & $\mathrm{AW}+\mathrm{TT}$ & GG shroud & GG3B-A-TT & 0.00 & 470 & $(220)$ & 30 & 2 & 16.5 & 4.8 & $1.22 \mathrm{E}-09$ & $4.57 \mathrm{E}-11$ \\
\hline $304 \mathrm{~L}$ & SAW HAZ & $\mathrm{AW}+\mathrm{TT}$ & GG shroud & GG3B-A-TT & 0.00 & 450 & $(220)$ & 300 & 2 & 16.7 & 5.0 & $2.80 \mathrm{E}-10$ & $5.25 \mathrm{E}-12$ \\
\hline $304 \mathrm{~L}$ & SAW HAZ & $\mathrm{AW}+\mathrm{TT}$ & GG shroud & GG3B-A-TT & 0.00 & 400 & $(220)$ & 1,000 & 12 & 16.7 & 5.0 & $1.12 \mathrm{E}-10$ & $1.57 \mathrm{E}-12$ \\
\hline 304 & SMAW HAZ & As welded & 10285 & 85-YA & 0.00 & 300 & (180) & 0.5 & 0.5 & 16.2 & 10.8 & $4.73 \mathrm{E}-08$ & $2.84 \mathrm{E}-08$ \\
\hline 304 & SMAW HAZ & As welded & 10285 & 85-YA & 0.00 & 300 & $(180)$ & 10 & 10 & 16.7 & 11.2 & 5.72E-09 & 1.60E-09 \\
\hline 304 & SMAW HAZ & As welded & 10285 & 85-YA & 0.00 & 300 & $(180)$ & 300 & 12 & 16.7 & 8.0 & $2.19 \mathrm{E}-11$ & $2.12 \mathrm{E}-11$ \\
\hline 304 & SMAW HAZ & As welded & 10285 & 85-YA & 0.00 & 300 & $(180)$ & 30 & 12 & 16.7 & 8.0 & $2.51 \mathrm{E}-10$ & $2.15 \mathrm{E}-10$ \\
\hline 304 & SMAW HAZ & As welded & 10285 & 85-YA & 0.00 & 300 & (180) & 30 & 12 & 19.2 & 9.2 & $6.21 \mathrm{E}-10$ & $3.39 \mathrm{E}-10$ \\
\hline 304 & SMAW HAZ & As welded & 10285 & 85-YA & 0.00 & 300 & (180) & 300 & 12 & 19.3 & 9.5 & $3.68 \mathrm{E}-10$ & $3.66 \mathrm{E}-11$ \\
\hline 304 & SMAW HAZ & As welded & 10285 & 85-YA & 0.00 & 300 & (1 & 1,000 & 12 & 19.8 & 9.7 & $1.85 \mathrm{E}-10$ & $1.19 \mathrm{E}-11$ \\
\hline 304 & SMAW HAZ & $\mathrm{AW}+\mathrm{TT}$ & 10285 & 85-3A-TT & 0.00 & 690 & (230) & 0.5 & 0.5 & 16.1 & 12.7 & $5.46 \mathrm{E}-08$ & $4.21 \mathrm{E}-08$ \\
\hline 304 & SMAW HAZ & $\mathrm{AW}+\mathrm{TT}$ & 10285 & 85-3A-TT & 0.00 & 650 & (230) & 0.5 & 0.5 & 15.0 & 11.9 & $5.00 \mathrm{E}-08$ & 3.32E-08 \\
\hline 304 & SMAW HAZ & $\mathrm{AW}+\mathrm{TT}$ & 10285 & $85-3 \mathrm{~A}-\mathrm{TT}$ & 0.00 & 600 & (230) & 30 & 2 & 14.6 & 7.2 & $5.61 \mathrm{E}-11$ & $1.47 \mathrm{E}-10$ \\
\hline 304 & SMAW HAZ & $\mathrm{AW}+\mathrm{TT}$ & 10285 & 85-3A-TT & 0.00 & 600 & (230) & 30 & 2 & 16.7 & 8.2 & $5.50 \mathrm{E}-10$ & $2.28 \mathrm{E}-10$ \\
\hline 304 & SMAW HAZ & $\mathrm{AW}+\mathrm{TT}$ & 10285 & $85-3 \mathrm{~A}-\mathrm{TT}$ & 0.00 & 600 & (230) & 30 & 2 & 16.9 & 4.9 & $3.16 \mathrm{E}-11$ & 4.96E-11 \\
\hline 304 & SMAW HAZ & $\mathrm{AW}+\mathrm{TT}$ & 10285 & 85-3A-TT & 0.00 & 600 & (230) & 30 & 2 & 19.8 & 5.8 & $8.85 \mathrm{E}-10$ & 8.39E-11 \\
\hline 304 & SMAW HAZ & $\mathrm{AW}+\mathrm{TT}$ & 10285 & $85-3 \mathrm{~A}-\mathrm{TT}$ & 0.00 & 600 & (230) & 300 & 2 & 19.8 & 5.7 & $2.75 \mathrm{E}-10$ & 8.37E-12 \\
\hline 304 & SMAW HAZ & $\mathrm{AW}+\mathrm{TT}$ & 10285 & $85-3 \mathrm{~A}-\mathrm{TT}$ & 0.00 & 600 & $(230)$ & 300 & 2 & 20.2 & 5.9 & $7.91 \mathrm{E}-10$ & 8.99E-12 \\
\hline 304 & SMAW HAZ & $\mathrm{AW}+\mathrm{TT}$ & 10285 & 85-3A-TT & 0.00 & 600 & (230) & 1,000 & 2 & 20.5 & 6.2 & $4.57 \mathrm{E}-10$ & $3.13 \mathrm{E}-12$ \\
\hline $304 \mathrm{~L}$ & SAW HAZ & As welded & GG shroud & GG5T-A & 0.75 & 250 & 205 & 0.5 & 0.5 & 12.4 & 10.3 & $1.71 \mathrm{E}-08$ & $1.97 \mathrm{E}-08$ \\
\hline $304 \mathrm{~L}$ & SAW HAZ & As welded & GG shroud & GG5T-A & 0.75 & 250 & 20 & 0 & 0 & 12.3 & 8.9 & $3.11 \mathrm{E}-09$ & $1.39 \mathrm{E}-08$ \\
\hline $304 \mathrm{~L}$ & SAW HAZ & As welded & GG shroud & GG5T-A & 0.75 & 250 & 20 & 0 . & 0.5 & 12.8 & 8.9 & $2.70 \mathrm{E}-09$ & $1.45 \mathrm{E}-08$ \\
\hline $304 \mathrm{~L}$ & SAW HAZ & As welded & GG shroud & GG5T-A & 0.75 & 250 & 201 & 0.5 & 0.5 & 13.5 & 9.2 & $1.06 \mathrm{E}-08$ & $1.64 \mathrm{E}-08$ \\
\hline $304 \mathrm{~L}$ & SAW HAZ & As welded & GG shroud & GG5T-A & 0.75 & 250 & 195 & 60 & 4 & 14.3 & 6.9 & $4.30 \mathrm{E}-11$ & $6.35 \mathrm{E}-11$ \\
\hline $304 \mathrm{~L}$ & SAW HAZ & As welded & GG shroud & GG5T-A & 0.75 & 250 & 195 & 60 & 4 & 15.3 & 7.4 & $1.61 \mathrm{E}-09$ & $8.04 \mathrm{E}-11$ \\
\hline $304 \mathrm{~L}$ & SAW HAZ & As welded & GG shroud & GG5T-A & 0.75 & 250 & 196 & 300 & 4 & 14.7 & 4.6 & $3.34 \mathrm{E}-10$ & $3.85 \mathrm{E}-12$ \\
\hline $304 \mathrm{~L}$ & SAW HAZ & As welded & GG shroud & GG5T-A & 0.75 & 250 & 196 & 1,000 & 12 & 14.7 & 4.6 & $3.89 \mathrm{E}-10$ & $1.15 \mathrm{E}-12$ \\
\hline $304 \mathrm{~L}$ & SAW HAZ & As welded & GG shroud & GG5T-A & 0.75 & 250 & 196 & 60 & 12 & 15.3 & 4.6 & $3.10 \mathrm{E}-11$ & $1.98 \mathrm{E}-11$ \\
\hline $304 \mathrm{~L}$ & SAW HAZ & As welded & GG shroud & GG5T-A & 0.75 & 250 & 199 & 60 & 12 & 16.6 & 4.8 & $8.03 \mathrm{E}-11$ & $2.36 \mathrm{E}-11$ \\
\hline $304 \mathrm{~L}$ & SAW HAZ & As welded & GG shroud & GG5T-A & 0.75 & 250 & 193 & 30 & 4 & 16.6 & 8.1 & $8.57 \mathrm{E}-11$ & $2.22 \mathrm{E}-10$ \\
\hline $304 \mathrm{~L}$ & SAW HAZ & As welded & GG shroud & GG5T-B & 0.75 & 400 & 211 & 0.5 & 0.5 & 13.8 & 11.0 & $7.24 \mathrm{E}-09$ & $2.56 \mathrm{E}-08$ \\
\hline $304 \mathrm{~L}$ & SAW HAZ & As welded & GG shroud & GG5T-B & 0.75 & 400 & 200 & 0.5 & 0.5 & 13.0 & 9.1 & $4.59 \mathrm{E}-09$ & $1.55 \mathrm{E}-08$ \\
\hline $304 \mathrm{~L}$ & SAW HAZ & As welded & GG shroud & GG5T-B & 0.75 & 350 & 206 & 60 & 4 & 12.8 & 6.4 & $1.50 \mathrm{E}-12$ & $4.93 \mathrm{E}-11$ \\
\hline $304 \mathrm{~L}$ & SAW HAZ & As welded & GG shroud & GG5T-B & 0.75 & 350 & 199 & 30 & 4 & 14.4 & 7.1 & $9.13 \mathrm{E}-10$ & $1.39 \mathrm{E}-10$ \\
\hline
\end{tabular}


Table 15. (Contd.)

\begin{tabular}{|c|c|c|c|c|c|c|c|c|c|c|c|c|c|}
\hline $\begin{array}{l}\text { Steel } \\
\text { Type }\end{array}$ & Materiala $^{\mathrm{a}}$ & Condition ${ }^{\mathrm{b}}$ & Heat ${ }^{c}$ & $\begin{array}{l}\text { Spec. } \\
\text { ID }\end{array}$ & $\begin{array}{c}\text { Dose, } \\
\text { dpa }\end{array}$ & $\begin{array}{l}\text { DO, } \\
\mathrm{ppb}\end{array}$ & $\begin{array}{c}\text { ECP, }{ }^{\mathrm{d}} \\
\mathrm{mV} \text { (SHE) }\end{array}$ & $\begin{array}{c}\text { Rise } \\
\text { Time, } \mathrm{s}\end{array}$ & $\begin{array}{l}\text { Return } \\
\text { Time, } \mathrm{s}\end{array}$ & $\begin{array}{c}\mathrm{K}_{\max }, \\
\mathrm{MPa} \mathrm{m}^{1 / 2}\end{array}$ & $\begin{array}{c}\Delta \mathrm{K}, \\
2 \mathrm{MPa} \mathrm{m}^{1 / 2}\end{array}$ & $\begin{array}{c}\mathrm{CGR}, \\
\mathrm{m} / \mathrm{s}\end{array}$ & $\begin{array}{c}\mathrm{CGR}_{\text {air }}, \\
\mathrm{m} / \mathrm{s}\end{array}$ \\
\hline $304 \mathrm{~L}$ & SAW HAZ & \multicolumn{2}{|c|}{ As welded GG shroud } & GG5T-B & 0.75 & 350 & 199 & 300 & 4 & 14.7 & 7.5 & $2.82 \mathrm{E}-10$ & $1.67 \mathrm{E}-11$ \\
\hline $304 \mathrm{~L}$ & SAW HAZ & \multicolumn{2}{|c|}{ As welded GG shroud } & GG5T-B & 0.75 & 350 & 200 & 300 & 4 & 14.8 & 4.4 & $2.35 \mathrm{E}-10$ & $3.53 \mathrm{E}-12$ \\
\hline $304 \mathrm{~L}$ & SAW HAZ & \multicolumn{2}{|c|}{ As welded GG shroud } & GG5T-B & 0.75 & 350 & 200 & 1,000 & 12 & 14.7 & 4.7 & $2.98 \mathrm{E}-10$ & $1.26 \mathrm{E}-12$ \\
\hline $304 \mathrm{~L}$ & SAW HAZ & \multicolumn{2}{|c|}{ As welded GG shroud } & GG5T-B & 0.75 & $<50$ & -530 & 300 & 122 & 15.0 & 4.6 & $1.50 \mathrm{E}-12$ & $4.08 \mathrm{E}-12$ \\
\hline $304 \mathrm{~L}$ & SAW HAZ & \multicolumn{2}{|c|}{ As welded GG shroud } & GG6T-A & 2.16 & 600 & 232 & 0.18 & 0.18 & 15.2 & 11.2 & $4.54 \mathrm{E}-08$ & $8.20 \mathrm{E}-08$ \\
\hline $304 \mathrm{~L}$ & SAW HAZ & \multicolumn{2}{|c|}{ As welded GG shroud } & GG6T-A & 2.16 & 600 & 230 & 38 & 2.5 & 15.0 & 7.1 & $1.50 \mathrm{E}-12$ & $1.12 \mathrm{E}-10$ \\
\hline $304 \mathrm{~L}$ & SAW HAZ & \multicolumn{2}{|c|}{ As welded GG shroud } & GG6T-A & 2.16 & 600 & 229 & 0.18 & 0.18 & 15.3 & 10.9 & $5.93 \mathrm{E}-10$ & $7.68 \mathrm{E}-08$ \\
\hline $304 \mathrm{~L}$ & SAW HAZ & \multicolumn{2}{|c|}{ As welded GG shroud } & GG6T-A & 2.16 & 600 & 223 & 7.3 & 7.3 & 15.5 & 11.0 & $3.91 \mathrm{E}-10$ & $1.97 \mathrm{E}-09$ \\
\hline $304 \mathrm{~L}$ & SAW HAZ & \multicolumn{2}{|c|}{ As welded GG shroud } & GG6T-A & 2.16 & 600 & 223 & 7.4 & 2.5 & 15.4 & 6.6 & $1.44 \mathrm{E}-09$ & $4.79 \mathrm{E}-10$ \\
\hline $304 \mathrm{~L}$ & SAW HAZ & \multicolumn{2}{|c|}{ As welded GG shroud } & GG6T-A & 2.16 & 600 & 222 & 37 & 2.5 & 15.4 & 6.6 & $6.29 \mathrm{E}-10$ & $9.69 \mathrm{E}-11$ \\
\hline $304 \mathrm{~L}$ & SAW HAZ & \multicolumn{2}{|c|}{ As welded GG shroud } & GG6T-A & 2.16 & 600 & 220 & 168 & 6.7 & 16.3 & 5.4 & $7.85 \mathrm{E}-10$ & $1.15 \mathrm{E}-11$ \\
\hline $304 \mathrm{~L}$ & SAW HAZ & \multicolumn{2}{|c|}{ As welded GG shroud } & GG6T-A & 2.16 & 600 & 222 & 559 & 6.7 & 16.1 & 5.3 & $6.08 \mathrm{E}-10$ & $3.38 \mathrm{E}-12$ \\
\hline 304 & SMAW HAZ & As welded & 10285 & $85-7 \mathrm{~A}$ & 0.75 & 500 & 224 & 0.5 & 0.5 & 15.9 & 12.2 & $2.77 \mathrm{E}-08$ & $3.77 \mathrm{E}-08$ \\
\hline 304 & SMAW HAZ & As welded & 10285 & $85-7 \mathrm{~A}$ & 0.75 & 500 & 225 & 60 & 4 & 15.8 & 7.9 & $1.50 \mathrm{E}-12$ & $9.94 \mathrm{E}-11$ \\
\hline 304 & SMAW HAZ & As welded & 10285 & $85-7 \mathrm{~A}$ & 0.75 & 500 & 219 & 300 & 4 & 15.7 & 7.7 & $2.09 \mathrm{E}-11$ & $1.83 \mathrm{E}-11$ \\
\hline 304 & SMAW HAZ & As n & 10285 & $85-7 \mathrm{~A}$ & 0.75 & 500 & 221 & 1,000 & 12 & 16.4 & 8.2 & $1.50 \mathrm{E}-12$ & $6.71 \mathrm{E}-12$ \\
\hline 304 & SMAW HAZ & As welded & 10285 & $85-7 \mathrm{~A}$ & 0.75 & 500 & 211 & 1,000 & 12 & 17.2 & 8.1 & $4.65 \mathrm{E}-11$ & $6.66 \mathrm{E}-12$ \\
\hline 304 & SMAW HAZ & As welded & 10285 & $85-7 \mathrm{~A}$ & 0.75 & 500 & 209 & 1,000 & 12 & 18.3 & 9.1 & $4.28 \mathrm{E}-10$ & $9.69 \mathrm{E}-12$ \\
\hline 304 & SMAW HAZ & As welded & 10285 & 85-XA & 2.16 & 500 & 205 & 0.16 & 0.5 & 13.3 & 7.7 & $1.86 \mathrm{E}-08$ & $3.17 \mathrm{E}-08$ \\
\hline 304 & SMAW HAZ & As welded & 10285 & 85-XA & 2.16 & 500 & 240 & 26 & 4 & 13.9 & 3.6 & $2.21 \mathrm{E}-09$ & $2.13 \mathrm{E}-11$ \\
\hline 304 & SMAW HAZ & As welded & 10285 & 85-XA & 2.16 & 500 & 236 & 433 & 4 & 13.0 & 3.6 & $7.07 \mathrm{E}-10$ & $1.28 \mathrm{E}-12$ \\
\hline 304 & SMAW HAZ & $\mathrm{AW}+\mathrm{TT}$ & 10285 & 85-1A-TT & 0.75 & 200 & 163 & 0.25 & 0.25 & 13.9 & 11.6 & $2.64 \mathrm{E}-08$ & $5.81 \mathrm{E}-08$ \\
\hline 304 & SMAW HAZ & $\mathrm{AW}+\mathrm{TT}$ & 10285 & 85-1A-TT & 0.75 & 200 & 161 & 0.5 & 0.5 & 13.3 & 10.1 & $2.10 \mathrm{E}-08$ & $2.04 \mathrm{E}-08$ \\
\hline 304 & SMAW HAZ & $\mathrm{AW}+\mathrm{TT}$ & 10285 & $85-1 \mathrm{~A}-\mathrm{TT}$ & 0.75 & 200 & 166 & 60 & 4 & 14.6 & 7.3 & $1.50 \mathrm{E}-12$ & $7.76 \mathrm{E}-11$ \\
\hline 304 & SMAW HAZ & $\mathrm{AW}+\mathrm{TT}$ & 10285 & $85-1 \mathrm{~A}-\mathrm{TT}$ & 0.75 & 200 & 1 & 1,000 & 4 & 15.1 & 7.6 & $4.80 \mathrm{E}-10$ & $5.20 \mathrm{E}-12$ \\
\hline 304 & SMAW HAZ & $\mathrm{AW}+\mathrm{TT}$ & 10285 & $85-1 \mathrm{~A}-\mathrm{TT}$ & 0.75 & 250 & 1 & 300 & 4 & 16.1 & 4.8 & $3.55 \mathrm{E}-10$ & $4.66 \mathrm{E}-12$ \\
\hline 304 & SMAW HAZ & $\mathrm{AW}+\mathrm{TT}$ & 10285 & $85-1$ & 0.75 & 250 & 172 & 1,000 & 12 & 16.4 & 4.7 & 3.37 & $1.33 \mathrm{E}-12$ \\
\hline CF- $8 \mathrm{M}$ & Cast SS & Aged & 75 & 75-11TT & 2.46 & 600 & 201 & 0.14 & 0.14 & 11.3 & 6.1 & $2.70 \mathrm{E}-08$ & $1.76 \mathrm{E}-08$ \\
\hline CF- $8 \mathrm{M}$ & Cast SS & Aged & 75 & $75-11 \mathrm{TT}$ & 2.46 & 600 & 234 & 0.14 & 0.14 & 11.2 & 6.2 & $2.69 \mathrm{E}-09$ & $1.79 \mathrm{E}-08$ \\
\hline CF-8M & Cast SS & Aged & 75 & $75-11 \mathrm{TT}$ & 2.46 & 600 & 232 & 14.3 & 14.3 & 11.2 & 6.1 & $5.35 \mathrm{E}-11$ & $1.73 \mathrm{E}-10$ \\
\hline CF-8M & Cast SS & Aged & 75 & $75-11 \mathrm{TT}$ & 2.46 & 600 & 236 & 0.13 & 0.13 & 11.2 & 4.7 & $3.52 \mathrm{E}-09$ & $9.02 \mathrm{E}-09$ \\
\hline CF-8M & Cast SS & Aged & 75 & $75-11 \mathrm{TT}$ & 2.46 & 600 & 232 & 18 & 4 & 10.8 & 1.9 & $1.48 \mathrm{E}-10$ & $7.08 \mathrm{E}-12$ \\
\hline CF-8M & Cast SS & Aged & 75 & $75-11 \mathrm{TT}$ & 2.46 & 600 & 233 & 17.2 & 2.3 & 13.4 & 6.3 & $4.38 \mathrm{E}-10$ & $1.70 \mathrm{E}-10$ \\
\hline CF- $8 \mathrm{M}$ & Cast SS & Aged & 75 & $75-11 \mathrm{TT}$ & 2.46 & 600 & 229 & 34.8 & 7 & 13.5 & 6.4 & $5.69 \mathrm{E}-11$ & $8.61 \mathrm{E}-11$ \\
\hline CF-8M & Cast SS & Aged & 75 & $75-11 \mathrm{TT}$ & 2.46 & 600 & & 155 & 6.2 & 15.4 & 4.9 & $1.39 \mathrm{E}-11$ & $9.49 \mathrm{E}-12$ \\
\hline CF-8M & Cast SS & Aged & 75 & $75-11 \mathrm{TT}$ & 2.46 & 600 & 222 & 7.7 & 1.3 & 17.1 & 8.5 & $8.55 \mathrm{E}-10$ & $1.00 \mathrm{E}-09$ \\
\hline CF-8M & Cast SS & Aged & 75 & $75-11 \mathrm{TT}$ & 2.46 & 600 & 225 & 177 & 7 & 17.1 & 6.9 & $3.10 \mathrm{E}-11$ & $2.32 \mathrm{E}-11$ \\
\hline CF-8M & Cast SS & Aged & 75 & $75-11 \mathrm{TT}$ & 2.46 & 600 & 225 & 7.7 & 1.3 & 17.1 & 8.5 & $9.64 \mathrm{E}-10$ & $1.00 \mathrm{E}-09$ \\
\hline CF-8M & Cast SS & Aged & 75 & $75-11 \mathrm{TT}$ & 2.46 & 600 & 224 & 77 & 2.6 & 17.3 & 8.6 & $2.50 \mathrm{E}-10$ & $1.05 \mathrm{E}-10$ \\
\hline CF-8M & Cast SS & Aged & 75 & $75-11 \mathrm{TM}$ & 2.46 & 600 & 229 & 0.17 & 0.17 & 15.0 & 7.6 & $3.02 \mathrm{E}-08$ & $3.12 \mathrm{E}-08$ \\
\hline CF-8M & Cast SS & Aged & 75 & $75-11 \mathrm{TM}$ & 2.46 & 600 & 230 & 37 & 2.5 & 14.6 & 6.0 & $6.43 \mathrm{E}-10$ & $7.10 \mathrm{E}-11$ \\
\hline CF-8M & Cast SS & Aged & 75 & $75-11 \mathrm{TM}$ & 2.46 & 600 & 229 & 159 & 6.4 & 14.8 & 4.1 & $3.61 \mathrm{E}-10$ & $5.40 \mathrm{E}-12$ \\
\hline CF-8M & Cast SS & Aged & 75 & $75-11 \mathrm{TM}$ & 2.46 & 600 & 228 & 435 & 5.2 & 14.9 & 2.8 & $2.84 \mathrm{E}-10$ & $8.80 \mathrm{E}-13$ \\
\hline
\end{tabular}

\subsubsection{Solution-Annealed Materials}

Under continuous cyclic loading, the experimental CGRs and those predicted in air for the same loading conditions for solution-annealed Types 304 and 316 SSs irradiated up to 3 dpa and tested in highand low-DO environments are plotted in Fig. 65. The curves in the figures are based on the superposition model (Eq. 10). The cyclic CGRs in air $\left(\dot{a}_{\text {air }}\right)$ were determined from Eq. 11 developed by James and Jones. ${ }^{58}$ The corrosion fatigue contribution $\left(\dot{\mathrm{a}}_{\mathrm{cf}}\right)$ was determined from the Shack/Kassner model for nonirradiated SSs in high-purity water with either 8 or 0.2 ppm DO (Eqs. 14 and 15, respectively), ${ }^{59}$ and 
the SCC contribution ( $\dot{\mathrm{a}}_{\mathrm{scc}}$ ) was determined from Eq. $16 .{ }^{60}$ As discussed in the previous section, the CGR for SCC in SSs irradiated to $>0.75 \mathrm{dpa}$ was assumed to be a factor of six higher than that predicted by Eq. 16; as a result, the constant $\mathrm{A}$ in the equation was taken to be $1.26 \times 10^{-12}$ for irradiated SSs. For cyclic loading using either a triangular or a slow/fast sawtooth waveform, $\dot{\mathrm{a}}_{\text {scc }}$ is determined by considering the contribution of SCC during the slow rise time of the cycle; an equivalent $\mathrm{K}_{\max }$ is computed to determine the contribution of fatigue loading. The average values of $\mathrm{K}_{\max }$ used in calculating the superposition curves are given in the figure.

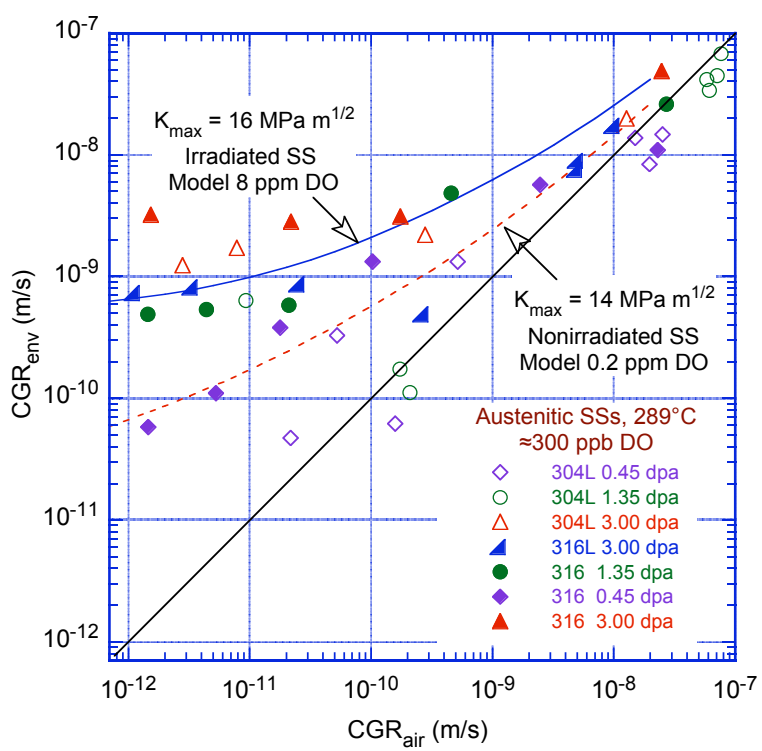

(a)

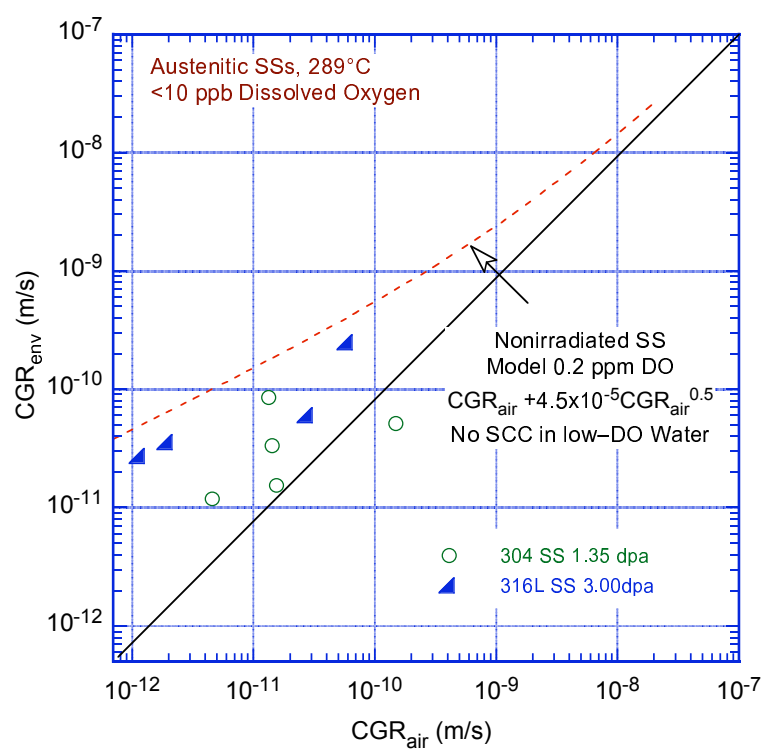

(b)

Figure 65. CGR for irradiated specimens of austenitic SSs under continuous cycling at $289^{\circ} \mathrm{C}$ in highpurity water with $(a) \approx 300 \mathrm{ppb}$ and $(b)<30 \mathrm{ppb}$ dissolved oxygen.

In these figures, the data points that lie along the diagonal represent predominantly mechanical fatigue, and those that lie close to the model curve indicate environmentally enhanced crack growth. Austenitic SS irradiated to 0.45 dpa shows very little environmental enhancement of CGRs in high-DO water (open and closed diamonds in Fig. 65a). For austenitic SSs irradiated to less than 0.5 dpa, the fatigue CGRs in water with $\approx 300 \mathrm{ppb}$ DO may be represented by superposition of the NUREG-0313 curve for nonirradiated $\mathrm{SSs}^{60}$ and by the Shack/Kassner model for nonirradiated austenitic SSs in highpurity water with $0.2 \mathrm{ppm}$ DO. .59

The results for SSs irradiated to 1.35 or 3.0 dpa indicate significant enhancement of the CGRs in high-DO water under cyclic loading with long rise times. For austenitic SSs irradiated to 0.75-3.0 dpa, the fatigue CGRs in water with $\approx 300 \mathrm{ppb}$ DO may be represented by superposition of the SCC curve for irradiated SSs (i.e., six times the NUREG-0313 curve) and by the Shack/Kassner model for nonirradiated SSs in high-purity water with 8 ppm DO. ${ }^{59}$

For continuous cyclic loading, decreasing the DO level has a beneficial effect on the CGRs of irradiated SSs; for example, decreasing the DO from $\approx 300 \mathrm{ppb}$ DO to $<30 \mathrm{ppb}$ DO lowers the CGR by a factor of 25 . At $289^{\circ} \mathrm{C}$, the fatigue CGRs for irradiated austenitic SSs in water with $<30 \mathrm{ppb}$ DO are lower than those predicted by the Shack/Kassner model for nonirradiated austenitic SSs in high-purity water with $0.2 \mathrm{ppm} \mathrm{DO} \mathrm{(Fig.} \mathrm{65b);}{ }^{59}$ there is no contribution of SCC in low-DO water. 


\subsubsection{Stainless Steel Weld HAZ Materials}

\subsubsection{Air Environment}

The experimental CGRs for SS weld HAZ materials under continuous cycling in air and those predicted for austenitic SSs under the same loading conditions are plotted in Fig. 66. Data obtained in the NWC BWR environment on the same materials are also included in the figure for comparison (open symbols). The results indicate that irradiation up to $\approx 2.16 \mathrm{dpa}$ has no effect on the fatigue CGRs of SS weld HAZ materials in air. In fact, the CGRs of irradiated material are slightly lower than those predicted by the correlations developed by James and Jones ${ }^{58}$ for nonirradiated solution-annealed SSs (i.e., the experimental CGRs of irradiated SS weld HAZ are below the diagonal in Fig. 66).

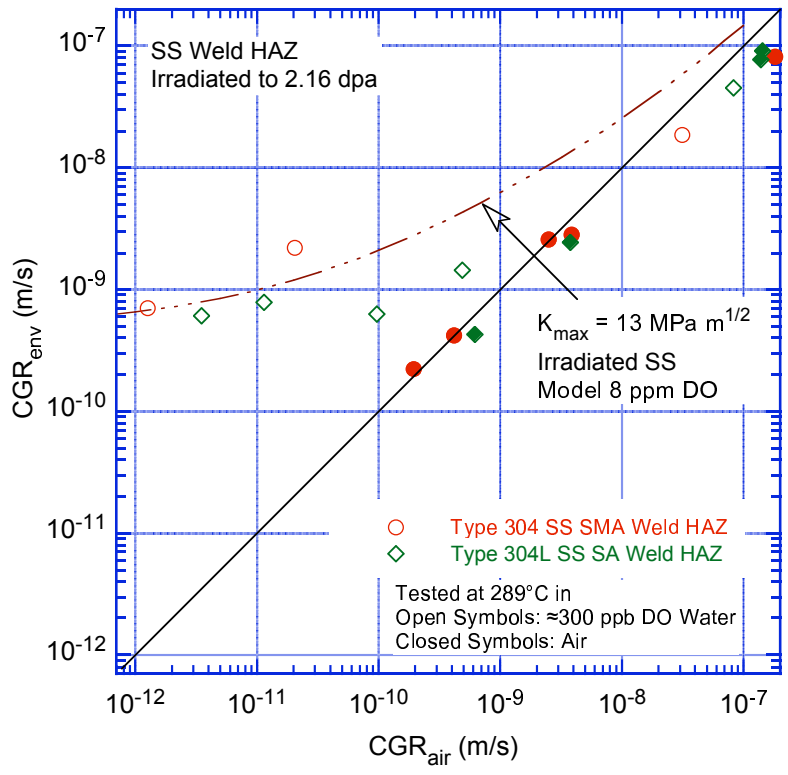

Figure 66.

CGR data under cyclic loading for irradiated SS weld HAZ materials in air and high-purity water at $289^{\circ} \mathrm{C}$.

\subsubsection{Simulated BWR Environment}

The experimental CGRs for nonirradiated SS weld HAZ materials in high-DO water ${ }^{54}$ and those predicted in air for the same loading conditions are plotted in Fig. 67; the loading conditions for the data points shown with a "+" did not satisfy the K/size criterion of ASTM E-647. The two curves in the figure are based on the superposition model. For the nonirradiated HAZ materials, the growth rate did not increase readily when the load ratio and rise time were increased. For example, a large number of data points lie along or below the diagonal in Fig. 67. The applied $\mathrm{K}_{\max }$ had to be increased for environmental enhancement.

In general, the fatigue CGRs of the nonirradiated HAZ materials in water with $300-500 \mathrm{ppb}$ DO are greater than those predicted by the Shack/Kassner model in high-purity water with $0.2 \mathrm{ppm}$ DO and lower than those predicted with 8 ppm DO. ${ }^{59}$ The fatigue CGRs of nonirradiated SS weld HAZ materials may be conservatively represented by superposition of the SCC curve for nonirradiated SSs and the Shack/Kassner model for austenitic SSs in high-purity water with $8 \mathrm{ppm}$ DO. The results also indicate that thermal treatment of the material for $24 \mathrm{~h}$ at $500^{\circ} \mathrm{C}$ has little or no effect on growth rates. 


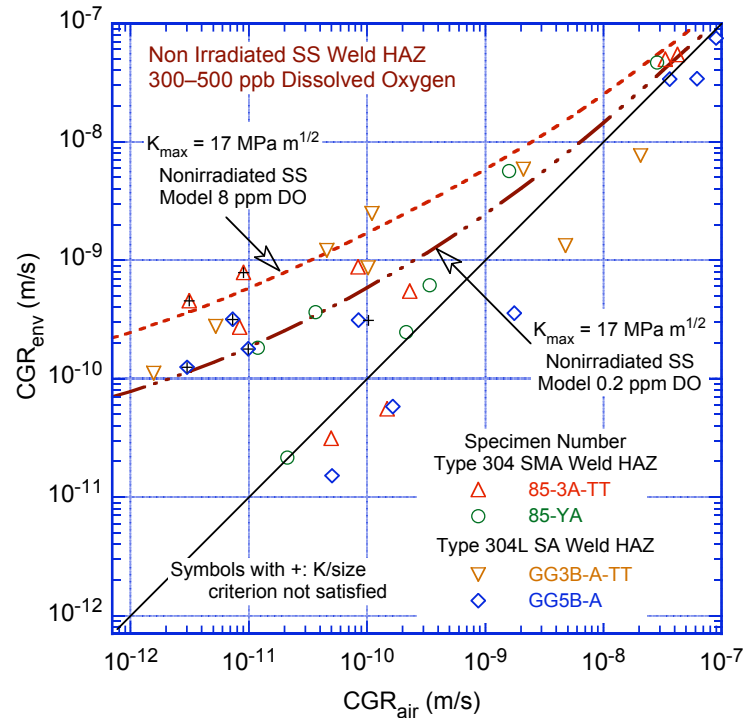

Figure 67.

CGR data under cyclic loading for nonirradiated SS weld HAZ materials in high-purity water at $289^{\circ} \mathrm{C}$

The experimental CGRs for irradiated GG Type 304L SA weld HAZ and laboratory-prepared Type 304 SMA weld HAZ in high-DO water and those predicted in air for the same loading conditions are plotted in Figs. 68a and 68b, respectively. The curve in the figures is based on the superposition model (Eq. 10). The results indicate significant environmental enhancement of CGRs for HAZ materials irradiated to 0.75 or $2.16 \mathrm{dpa}$. The CGRs of the GG Type 304L weld HAZ are slightly lower than those of the Type 304 SMA weld HAZ. The fatigue CGRs of SS weld HAZ materials irradiated to 0.75$2.16 \mathrm{dpa}$ in water containing $\approx 500 \mathrm{ppb}$ DO can be represented by superposition of the SCC curve for irradiated SSs (i.e., six times the NUREG-0313 curve) and the Shack/Kassner model for nonirradiated austenitic SSs in high-purity water with 8 ppm DO. ${ }^{59}$ The estimates may be somewhat conservative for Type 304L weld HAZ materials.

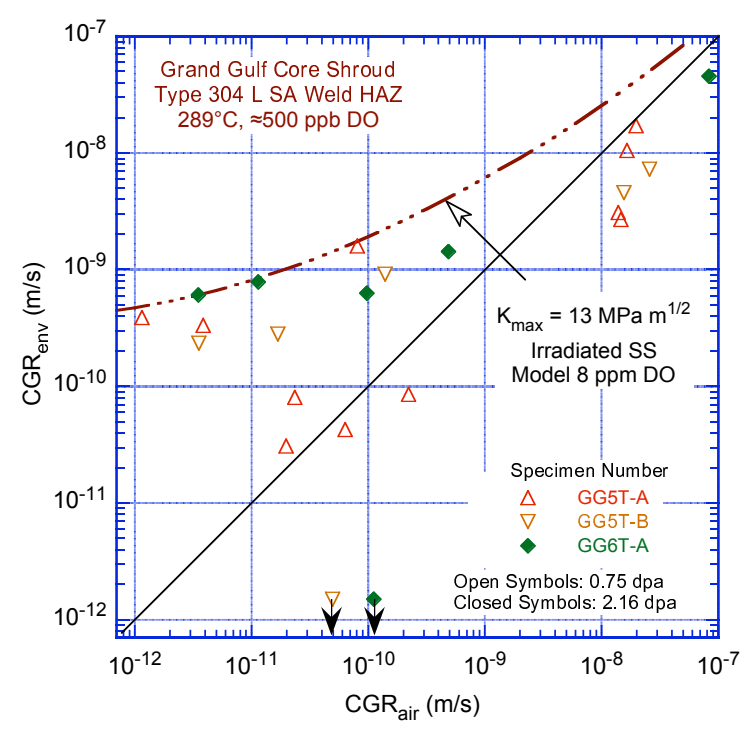

(a)

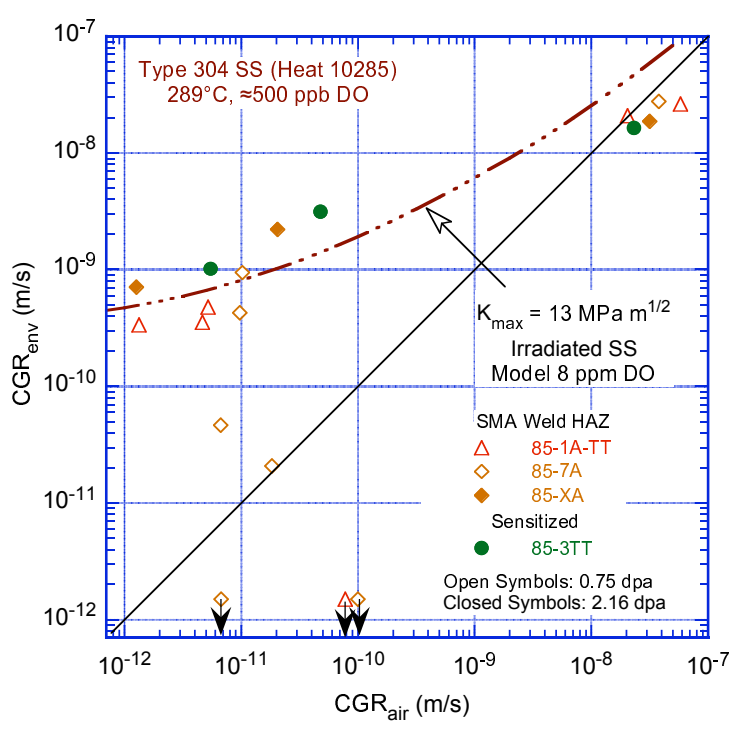

(b)

Figure 68. CGR for irradiated specimens of (a) Type 304L SA weld HAZ from the Grand Gulf core shroud and (b) laboratory-prepared Type 304 SS SMA weld HAZ under continuous cycling in high-purity water at $289^{\circ} \mathrm{C}$. 


\subsubsection{Cast Austenitic Stainless Steels}

The experimental CGRs for CF-8M cast austenitic SS under continuous cycling in the NWC BWR environment and those predicted for austenitic SSs under the same loading conditions in air are plotted in Fig. 69. The two curves in the figure are based on the superposition model. The material was thermally aged for $10,000 \mathrm{~h}$ at $400^{\circ} \mathrm{C}$ and then irradiated to $2.46 \mathrm{dpa}$ at $\approx 300^{\circ} \mathrm{C}$. As seen before for nonirradiated HAZ materials (Fig. 67), environmental enhancement of CGRs did not occur readily for Specimen 75$11 \mathrm{TT}$ when the load ratio and rise time were increased; for this specimen, a large number of data points lie along the diagonal in Fig. 69. The applied $\mathrm{K}_{\max }$ had to be increased for environmental enhancement.

Under similar loading and environmental conditions, the fatigue CGRs of CF-8M cast austenitic SS appear to be lower than those of wrought SSs or SS weld HAZ materials. Limited data indicate that the fatigue CGRs of SS weld HAZ materials irradiated to 0.75-2.46 dpa in water containing $\approx 300 \mathrm{ppb}$ DO can be represented by superposition of the SCC curve for irradiated SSs (i.e., six times the NUREG-0313 curve) and the Shack/Kassner model for nonirradiated austenitic SSs in high-purity water with $0.2 \mathrm{ppm}$ DO. 59

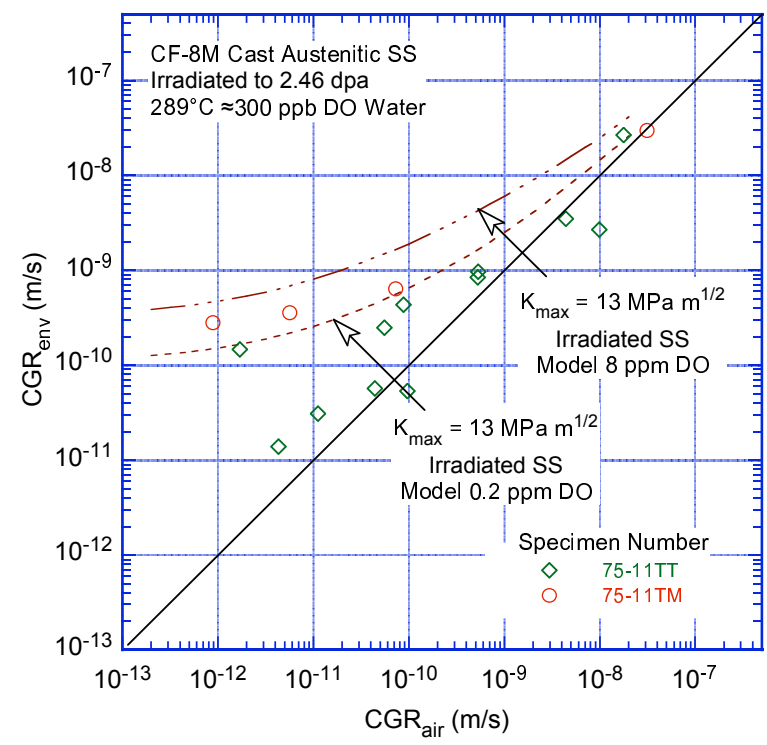

Figure 69.

CGR data under cyclic loading for irradiated CF-8M cast austenitic SS in high-purity water at $289^{\circ} \mathrm{C}$.

\subsection{Fracture Toughness of Irradiated Austenitic SSs}

Fracture toughness is typically characterized by the initiation toughness $\mathrm{J}_{\mathrm{Ic}}$ and tearing modulus $\mathrm{T}$ for materials that fail after substantial plastic deformation (conditions of EPFM) and by the critical stress intensity factor $\mathrm{K}_{\mathrm{Ic}}$ for materials that fail after little or no deformation (conditions of LEFM). Austenitic SSs have been divided into three broad categories of fracture toughness. ${ }^{3}$ Category III corresponds to high toughness materials with $\mathrm{J}_{\mathrm{Ic}}$ above $150 \mathrm{~kJ} / \mathrm{cm}^{2}$ (857 in.-lb/in. ${ }^{2}$ ). In these materials, fracture occurs after stable crack extension at stresses well above the yield stress. Category II corresponds to materials with intermediate toughness with $\mathrm{J}_{\mathrm{Ic}}$ in the range of $30-150 \mathrm{~kJ} / \mathrm{cm}^{2}\left(171-857 \mathrm{in} .-\mathrm{lb} / \mathrm{in} .^{2}\right)$. In these materials, fracture occurs by stable or unstable crack extension at stress levels close to the yield stress. Category I corresponds to low-toughness materials with $\mathrm{K}_{\mathrm{Ic}}$ less than $75 \mathrm{MPa} \mathrm{m}{ }^{1 / 2}\left(68.2 \mathrm{ksi} \mathrm{in.}^{1 / 2}\right)$ $\left[\mathrm{J}_{\mathrm{Ic}}<30 \mathrm{~kJ} / \mathrm{cm}^{2}\left(<171 \mathrm{in.-lb/in.}{ }^{2}\right)\right]$. In these materials, fracture occurs by unstable crack extension at stress levels well below the yield stress. 
Nonirradiated wrought and cast austenitic SSs and their welds fall in Category III. The $\mathrm{J}_{\text {Ic }}$ values for Types 304 and $316 \mathrm{SS}$ at temperatures up to $125^{\circ} \mathrm{C}\left(257^{\circ} \mathrm{F}\right)$ vary between 169 and $1660 \mathrm{~kJ} / \mathrm{cm}^{2}$ (965 and 9479 in.-lb/in. ${ }^{2}$ ), with a median value of $672 \mathrm{~kJ} / \mathrm{cm}^{2}$ (3837 in.-lb/in. $\left.{ }^{2}\right){ }^{3}$ The $\mathrm{J}_{\text {Ic }}$ values at 400 $550^{\circ} \mathrm{C}\left(752-1022^{\circ} \mathrm{F}\right)$ are $\approx 35 \%$ lower, with a median value of $421 \mathrm{~kJ} / \mathrm{cm}^{2}\left(2404 \mathrm{in} .-\mathrm{lb} / \mathrm{in} .{ }^{2}\right)$. Fracture in such high-toughness materials is by the nucleation and coalescence of microvoids and is characterized by a dimpled fracture morphology.

Although cast austenitic SSs and SS welds also exhibit ductile fracture at temperatures up to $550^{\circ} \mathrm{C}$ $\left(1022^{\circ} \mathrm{F}\right)$, their fracture toughness is lower than that of the wrought SSs. A dimpled fracture morphology is also observed in SS welds. Because of a high density of inclusions in the weld, the dimples are relatively small and shallow. Also, dimples are often associated with an inclusion and are initiated by a decohesion of the particle/matrix interface. The overall fracture toughness of cast austenitic SSs and SS welds is controlled by the density and morphology of second-phase inclusions in these materials and varies with the cast or weld process. For example, static cast products have lower fracture toughness than centrifugally cast pipes. Gas tungsten arc (GTA) welds exhibit the highest toughness; SMA welds have intermediate toughness; and SA welds have the lowest toughness. ${ }^{3}$ The median value of $\mathrm{J}_{\mathrm{Ic}}$ is $492 \mathrm{~kJ} / \mathrm{cm}^{2}$ (2809 in.-lb/in. ${ }^{2}$ ) for GTA welds and $147 \mathrm{~kJ} / \mathrm{cm}^{2}$ (839 in.-lb/in. ${ }^{2}$ ) for SA welds for temperatures up to $125^{\circ} \mathrm{C}\left(257^{\circ} \mathrm{F}\right)$.

Welding of austenitic SSs results in a HAZ adjacent to the fusion zone, where the material microstructure and microchemistry are greatly altered because of the precipitation of Cr-rich carbides at the grain boundaries. The formation of the carbides depletes $\mathrm{Cr}$ from the grain-boundary region, thereby creating a region that is susceptible to SCC. However, the fracture toughness of HAZ material is generally superior to that of the weld metal and may be comparable to that of the base metal.

Neutron irradiation can degrade fracture toughness of austenitic SSs to the level of Category II or I. The initiation toughness data $\left(\mathrm{J}_{\mathrm{IC}}\right)$ of irradiated SSs obtained in the present study, as well as those obtained earlier at ANL, ${ }^{27}$ are compared with similar data from other studies in Fig. 70. The scatter band for the data from fast reactor irradiations is also plotted in the figure. The results on BWR irradiated materials fall within the scatter band of the data obtained on materials irradiated in fast reactors at

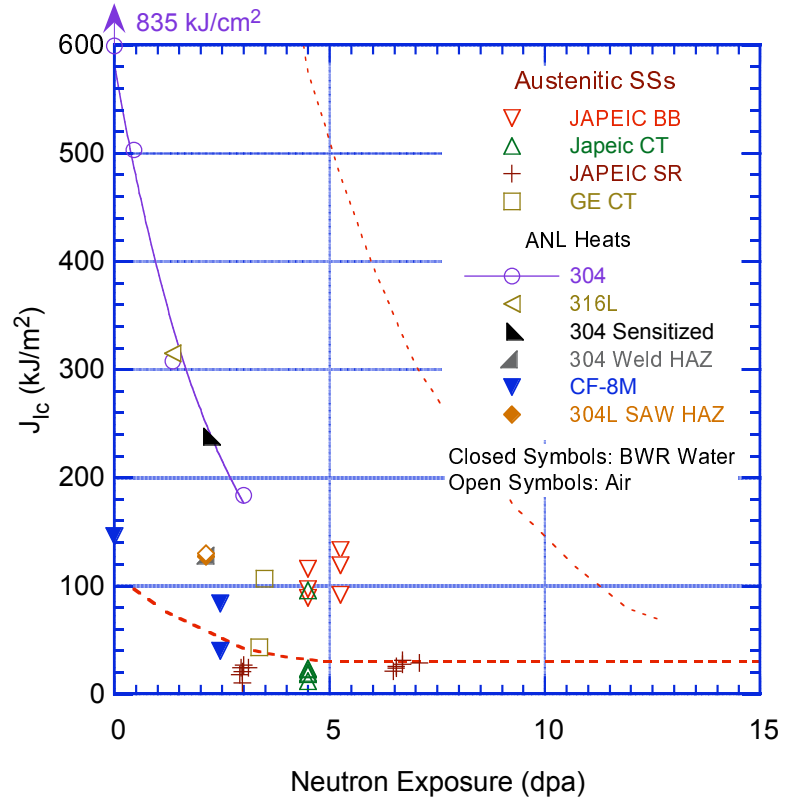

Figure 70.

Change in fracture toughness $\mathrm{J}_{\mathrm{IC}}$ as a function of neutron exposure for irradiated austenitic SSs. Dashed lines represent the scatter band for the fast reactor data on austenitic SSs irradiated at $350-450^{\circ} \mathrm{C}(662-$ $843^{\circ} \mathrm{F}$ ).

$\mathrm{GE}=$ General Electric Nuclear Energy, JAPEIC = Japan Power Engineering and Inspection Corporation, $\mathrm{CT}=$ compact tension, $\mathrm{BB}=$ bend bar, and $\mathrm{SR}=$ short rod. 
temperatures higher than $288^{\circ} \mathrm{C}\left(550^{\circ} \mathrm{F}\right)$. Also, the data for BWR irradiated materials indicate that the $\mathrm{J}_{\mathrm{Ic}}$ of austenitic SSs can decrease to $\approx 15 \mathrm{~kJ} / \mathrm{m}^{2}$ [corresponding to $\mathrm{K}_{\mathrm{Ic}}$ value of $54 \mathrm{MPa} \mathrm{m}{ }^{1 / 2}\left(38 \mathrm{ksi}\right.$ in. $\left.{ }^{1 / 2}\right)$ ] at neutron dose as low as 3-5 dpa. The significant results from the ANL study are summarized as follows:

(a) Neutron irradiation decreases the fracture toughness of SSs. The change in the fracture toughness J-R curve for irradiated Type 304 SS and CF-8M cast SS is shown in Figs. 71a and b, respectively.

(b) For the same irradiation conditions, the fracture toughness of the weld HAZ materials is lower than that of the solution-annealed materials, and the toughness of the thermally aged cast SS is lower than that of the HAZ material.

(c) Limited data indicate that the fracture toughness is approximately the same in air and simulated BWR environments. The use of an IG starter crack instead of a TG fatigue crack and the corrosion/oxidation reaction during crack extension had little or no effect on the fracture toughness of irradiated SSs. The fracture toughness J-R curves for SS weld HAZ materials in air and water environments are shown in Fig. 72.

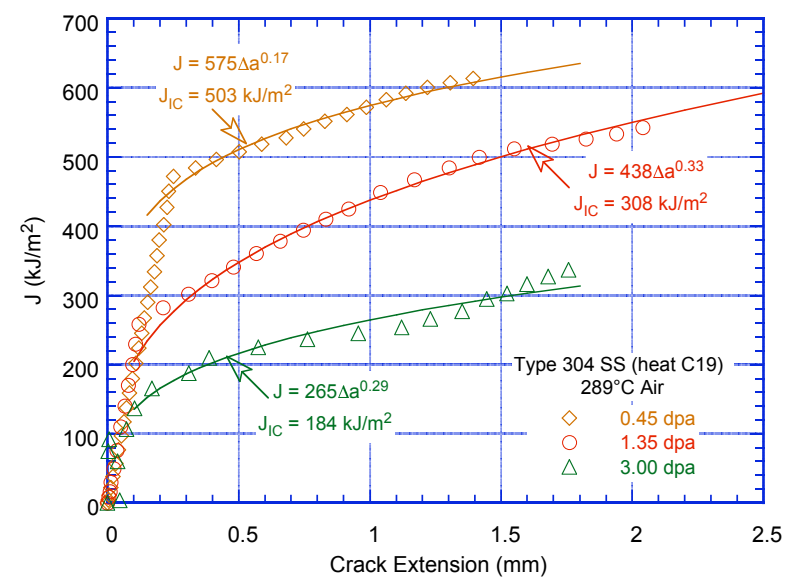

(a)

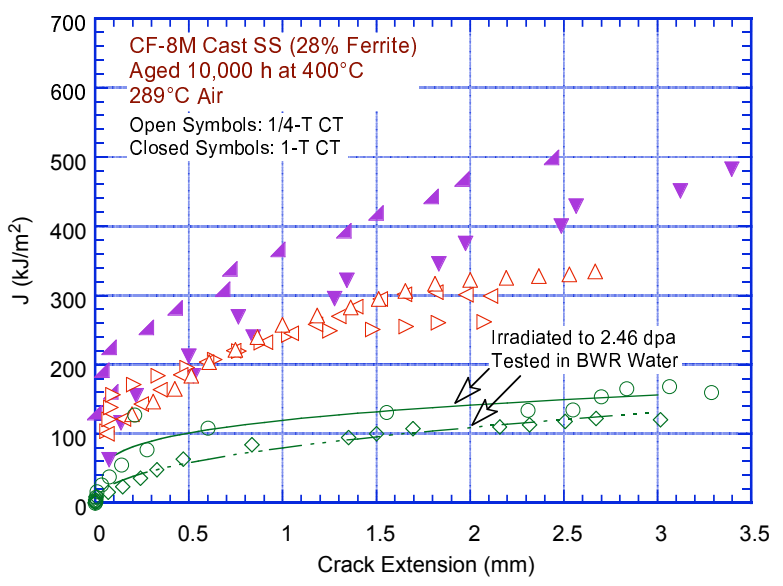

(b)

Figure 71. J-R curves for irradiated (a) Type $304 \mathrm{SS}$ and (b) thermally aged CF-8M cast SS at $289^{\circ} \mathrm{C}$.



(a)

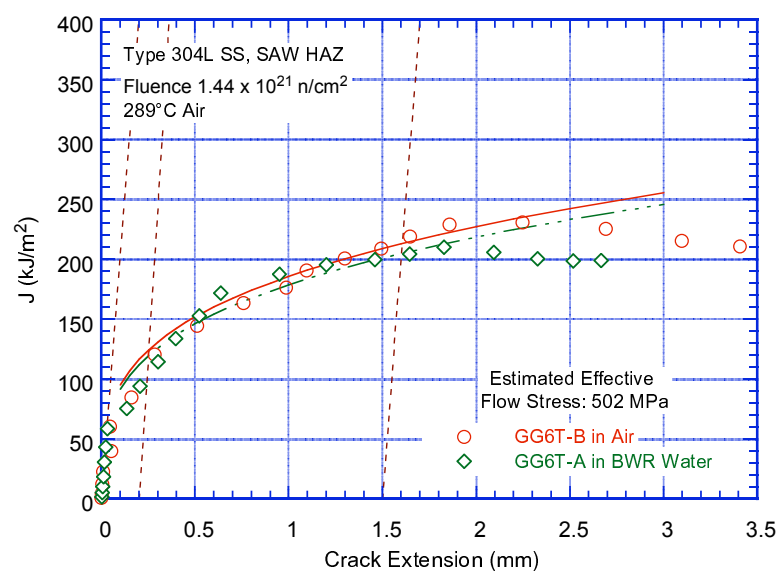

(b)

Figure 72. J-R curves for irradiated specimens of (a) Type 304 SS SMA weld HAZ and (b) Type 304L SA weld HAZ in air and BWR water environments. 


\subsubsection{Comparison with Fracture Toughness Data in the Literature}

The change in initiation toughness $\mathrm{J}_{\mathrm{Ic}}$ of wrought austenitic SSs and cast SSs and weld metals is shown in Fig. 73 as a function of neutron exposure (in dpa). The fracture toughness data from both fast reactor and LWR irradiations are included in the figures. The irradiation temperatures range from 90 to $427^{\circ} \mathrm{C}\left(194-800^{\circ} \mathrm{F}\right)$ and test temperatures from 100 to $427^{\circ} \mathrm{C}\left(212-800^{\circ} \mathrm{F}\right)$; some of the tests were conducted at room temperature. The procedures for determining $\mathrm{J}_{\mathrm{Ic}}$ vary among these studies. For example, in earlier studies a bilinear J-R curve was used to fit the data, whereas a power-law curve was used in the more recent studies. Different expressions have also been used for the blunting line. For example, for high-strain-hardening materials such as austenitic SSs, a slope of $4 \sigma_{\mathrm{f}}$ is generally used for the blunting line, while the ASTM specifications define it as $2 \sigma_{\mathrm{f}}$. A slope of $4 \sigma_{\mathrm{f}}$ will yield lower $\mathrm{J}_{\mathrm{Ic}}$ values. Also, in the present study, to account for possible strain softening that may occur in irradiated materials, an effective flow stress (defined as the average of the nonirradiated and irradiated flow stress) was used in J-R curve data analysis. Earlier studies have used the irradiated flow stress.

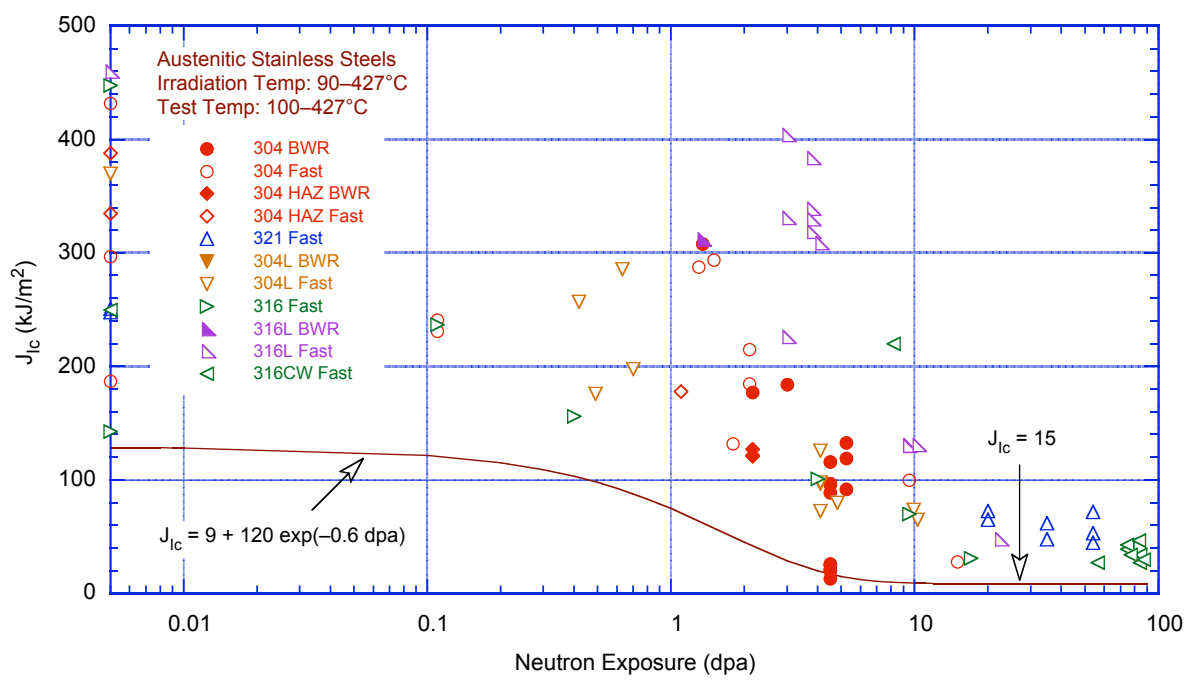

(a)

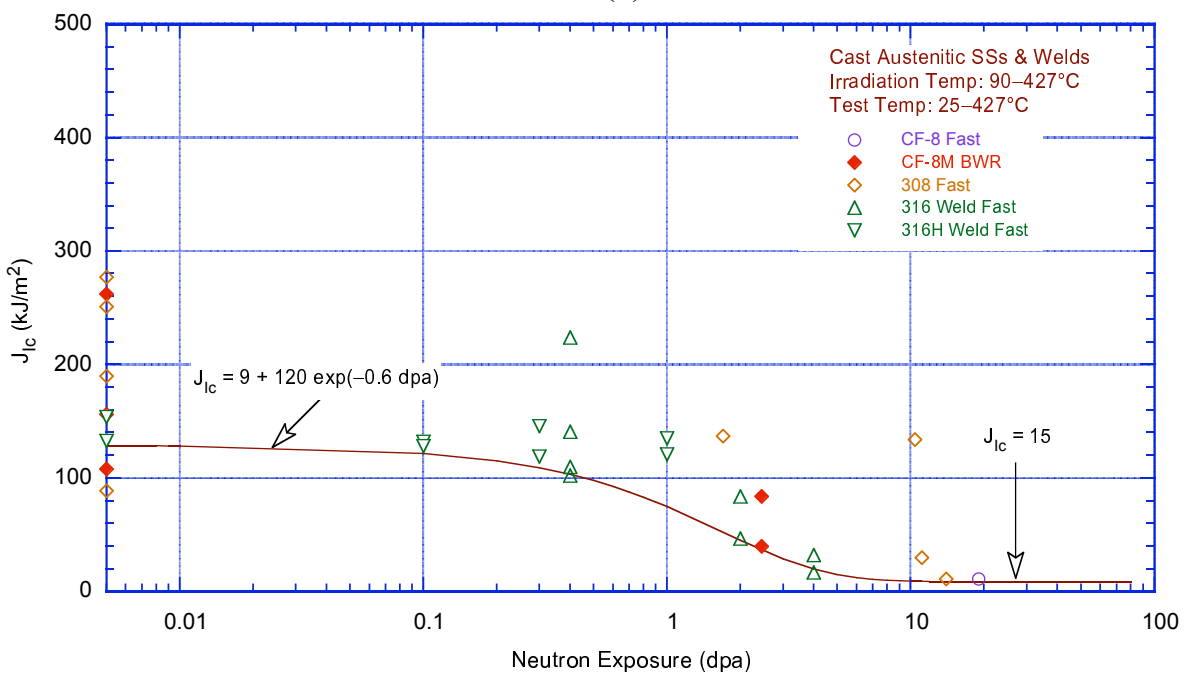

(b)

Figure 73. The change in initiation toughness $J_{I c}$ of (a) wrought austenitic $S S$ s and (b) cast austenitic SSs and weld metals as a function of neutron exposure (in dpa). 
The data in Fig. 73a indicate some differences in behavior between subsets of the data. The average $\mathrm{J}_{\mathrm{Ic}}$ of the Type $304 \mathrm{SS}$ drops from $\approx 350 \mathrm{~kJ} / \mathrm{m}^{2}\left(1999 \mathrm{in} .-1 \mathrm{~b} / \mathrm{in} .^{2}\right)$ at $1 \mathrm{dpa}$ to $\approx 75 \mathrm{~kJ} / \mathrm{m}^{2}$ $\left(\approx 428\right.$ in.-lb/in. $\left.{ }^{2}\right)$ at 5 dpa. The sharp drop in $\mathrm{J}_{\mathrm{Ic}}$ for Type $316 \mathrm{~L} \mathrm{SS}$ appears to occur at a somewhat higher fluence range ( $3 \mathrm{dpa}$ to $10 \mathrm{dpa}$ ). The drop in Type 304L SS appears to occur at a somewhat lower fluence. Overall, the results indicate little or no change in toughness below $0.5 \mathrm{dpa}$, a rapid decrease between 1 and $5 \mathrm{dpa}$, and no further change (saturation) beyond $10 \mathrm{dpa}$. The overall pattern is that with increasing fluence, the decrease in toughness is the earliest for Type $304 \mathrm{~L} \mathrm{SS}$, followed by Type 304 SS, and then Type $316 \mathrm{SS}$. The data in Fig. $73 \mathrm{~b}$ also show that the toughness of cast SSs and welds is lower than that of the wrought SSs for all fluences less than the 10-dpa saturation level. The existing data for welds indicate that $\approx 0.3 \mathrm{dpa}$ can be considered a threshold neutron dose below which irradiation has little or no effect on fracture toughness. The fracture toughness of austenitic SSs irradiated at less than the threshold dose will have a minimum $\mathrm{J}_{\mathrm{Ic}}$ of $135 \mathrm{~kJ} / \mathrm{m}^{2}\left(771 \mathrm{in.}-\mathrm{lb} / \mathrm{in} .^{2}\right)$.

The following summarizes the conclusions regarding the effects of parameters such as material type and heat treatment; irradiation conditions such as spectrum, flux, temperature, and dose; and test temperature.

Irradiation Facility: Fast reactor irradiations are at fluxes and temperatures higher than those typically observed in LWRs and have a different spectrum. All of the high neutron exposure data $(\geq 20 \mathrm{dpa})$ are from fast reactor irradiations at $\geq 400^{\circ} \mathrm{C}\left(\geq 752^{\circ} \mathrm{F}\right)$. An accurate determination of the effects of neutron spectrum, flux, and temperature on the fracture properties of these materials requires data on the same heat of material irradiated in a fast reactor and an LWR to comparable neutron dose. Such information is not available. However, the general data trends appear to be similar for fast reactor and LWR irradiations.

Material Type: Some differences in the fracture toughness data trends appear for the various grades of wrought austenitic SSs, but these differences may be artifacts of the limited data. The heat-to-heat variation for a particular grade may be comparable to the apparent differences between grades in the current data. Although the fracture toughness of nonirradiated cold-worked (CW) steels is lower than that of nonirradiated solution-annealed steels, the decrease in toughness of CW steels with neutron exposure is slower and the $\mathrm{J}_{\mathrm{Ic}}$ value at saturation is higher than that of irradiated solution-annealed steels. However, the data for $\mathrm{CW}$ steels are from fast reactor irradiations and at relatively high temperatures, $400-427^{\circ} \mathrm{C}$ $\left(752-800^{\circ} \mathrm{F}\right)$. As discussed below, the saturation $\mathrm{J}_{\mathrm{Ic}}$ for CW SSs is likely to be lower for irradiations at LWR operating temperatures, which are $290-320^{\circ} \mathrm{C}\left(554-608^{\circ} \mathrm{F}\right)$, so the differences may be smaller than indicated in Fig. $73 b$.

Nonirradiated weld metals and thermally aged cast SSs have lower fracture toughness than wrought materials, and the toughness may decrease somewhat more rapidly with neutron fluence than that of solution-annealed material. However, the saturation toughness for the welds is not significantly different from that of solution-annealed SSs, and the same bounding curve for $\mathrm{J}_{\mathrm{Ic}}$ appears applicable to both wrought and weld and cast materials. Although LWR core internals are typically constructed of CF-8 or CF-3 steels, the only data for LWR irradiation of cast SS are for CF-8M steel. For thermal embrittlement of cast SSs the fracture toughness of CF-8M steel represents the worst-case scenario. ${ }^{28,30}$ It thus might represent a bounding case also for the synergistic effects of irradiation and thermal aging.

Irradiation Temperature: The available data are inadequate to establish accurately the effects of the irradiation temperature on the fracture toughness of austenitic SSs. However, tensile data for austenitic SSs indicate that irradiation hardening is the highest, and ductility loss is maximum, at an irradiation temperature of $\approx 300^{\circ} \mathrm{C}\left(\approx 572^{\circ} \mathrm{F}\right) .{ }^{10}$ In Fig. 73 , the $\mathrm{J}_{\mathrm{Ic}}$ values for all of the data at neutron exposures 
greater than $20 \mathrm{dpa}$ may overestimate the toughness for irradiation temperatures of $290-320^{\circ} \mathrm{C}$ $\left(554-608^{\circ} \mathrm{F}\right)$ because the irradiation temperatures were above $300^{\circ} \mathrm{C}\left(572^{\circ} \mathrm{F}\right)$.

Test Temperature: The fracture toughness of nonirradiated austenitic SSs is known to decrease as the test temperature is increased. The change in the $\mathrm{J}_{\mathrm{Ic}}$ of irradiated SSs as a function of test temperature is plotted in Fig. 74 for several grades of SSs and welds. The fracture toughness of steels irradiated to relatively low dose (less than $5 \mathrm{dpa}$ ) also decreases with increasing test temperature in most cases. However, for steels irradiated to more than $12 \mathrm{dpa}$, test temperature has little effect on fracture toughness. Similar data on materials irradiated in LWRs are not available in the open literature.

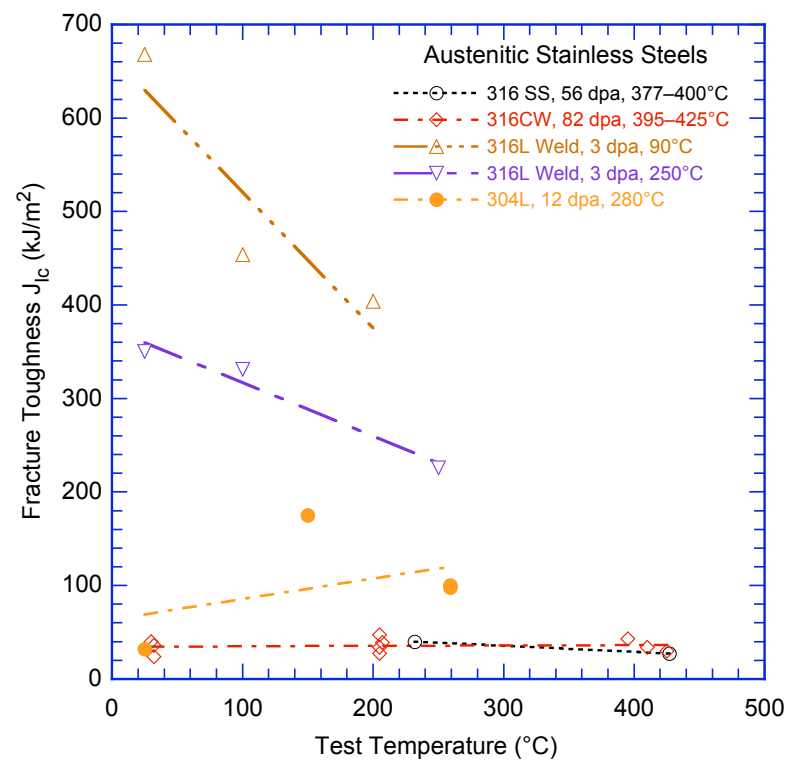

Figure 74.

Fracture toughness $J_{I c}$ of irradiated austenitic stainless steels and welds as a function of test temperature.

The effect of test temperature is also reflected in the fracture morphology of highly irradiated materials. At temperatures above $230^{\circ} \mathrm{C}\left(446^{\circ} \mathrm{F}\right)$ the failure mode is predominantly channel fracture characterized by a faceted fracture surface. It is caused by highly localized deformation along a narrow band of slip planes whereby dislocation motion along the narrow band clears the irradiation-induced defect structure, creating a defect-free channel that offers less resistance to subsequent dislocation motion. The localization of the deformation ultimately leads to channel failure. At temperatures $\leq 205^{\circ} \mathrm{C}$ $\left(\leq 400^{\circ} \mathrm{F}\right)$, Hamilton et al. ${ }^{23}$ observed quasi-cleavage fracture in $20 \% \mathrm{CW}$ Type $316 \mathrm{SS}$ irradiated to $77-87 \mathrm{dpa}$ at $395-425^{\circ} \mathrm{C}\left(743-797^{\circ} \mathrm{F}\right)$ in a fast reactor. The brittle fracture was believed to be an indirect consequence of the onset of void swelling in the material. The segregation of $\mathrm{Ni}$ to the void surfaces depletes $\mathrm{Ni}$ and enriches $\mathrm{Cr}$ in the region between voids, leading to extensive formation of $\varepsilon$-martensite and an embrittlement failure mode.

Test Environment: Nearly all of the existing fracture toughness data have been obtained from tests in air and on specimens that were fatigue precracked at relatively low load ratios (typically $0.1-0.2$ ) in room-temperature air. However, in reactor core components cracks are initiated primarily by SCC and have IG morphology, whereas the fatigue precracks in fracture toughness tests are always TG. Also, the corrosion/oxidation reaction could influence fracture toughness. For example, hydrogen generated from the oxidation reaction could diffuse into the material and change the deformation behavior by changing the stacking-fault energy of the material. However, limited data on irradiated SS weld HAZ materials (Fig. 72) indicate that an NWC BWR environment has little or no effect on the fracture toughness J-R curves. Similar tests in air and water environments have not been conducted on irradiated wrought or 
cast SSs. In the present study, large load drops were observed at the onset of crack extension during the two tests on irradiated CF-8M cast SS. Such load drops, typically, are not observed during tests in air. ${ }^{28}$

The effect of neutron irradiation on the fracture toughness of austenitic SSs can also be represented by the decrease in the coefficient $\mathrm{C}$ of the power-law correlation for the J-R curve with neutron dose. The change in coefficient $\mathrm{C}$ for wrought and cast SSs and welds is plotted as a function of neutron dose in Fig. 75. The results indicate that, even for fluence levels above $10 \mathrm{dpa}$, most heats of wrought austenitic SSs show ductile crack extension in the toughness tests. Under similar irradiation conditions, coefficient $\mathrm{C}$ of cast SSs and welds is lower than that of wrought SSs. There are less data at high fluences for cast SSs and weld metals. However, since most of the data are from irradiations in fast reactors and at temperatures of $370-427^{\circ} \mathrm{C}\left(698-800^{\circ} \mathrm{F}\right)$, the values of $\mathrm{C}$ are likely to be lower for irradiations at LWR operating temperatures.

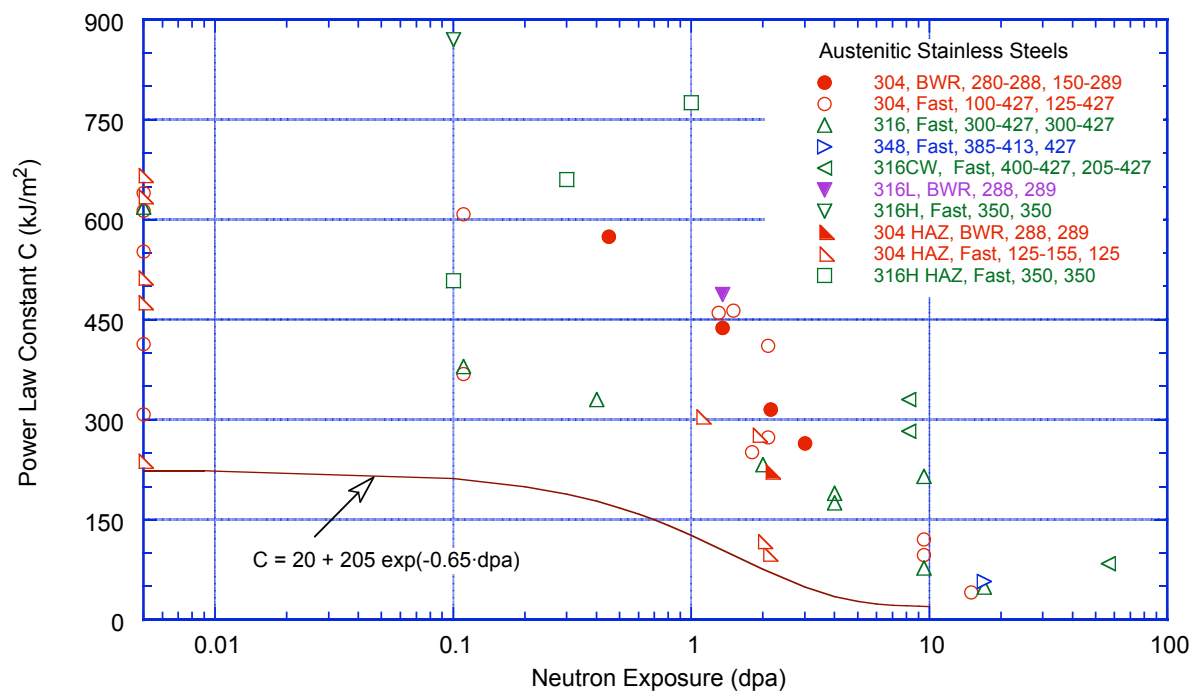

(a)

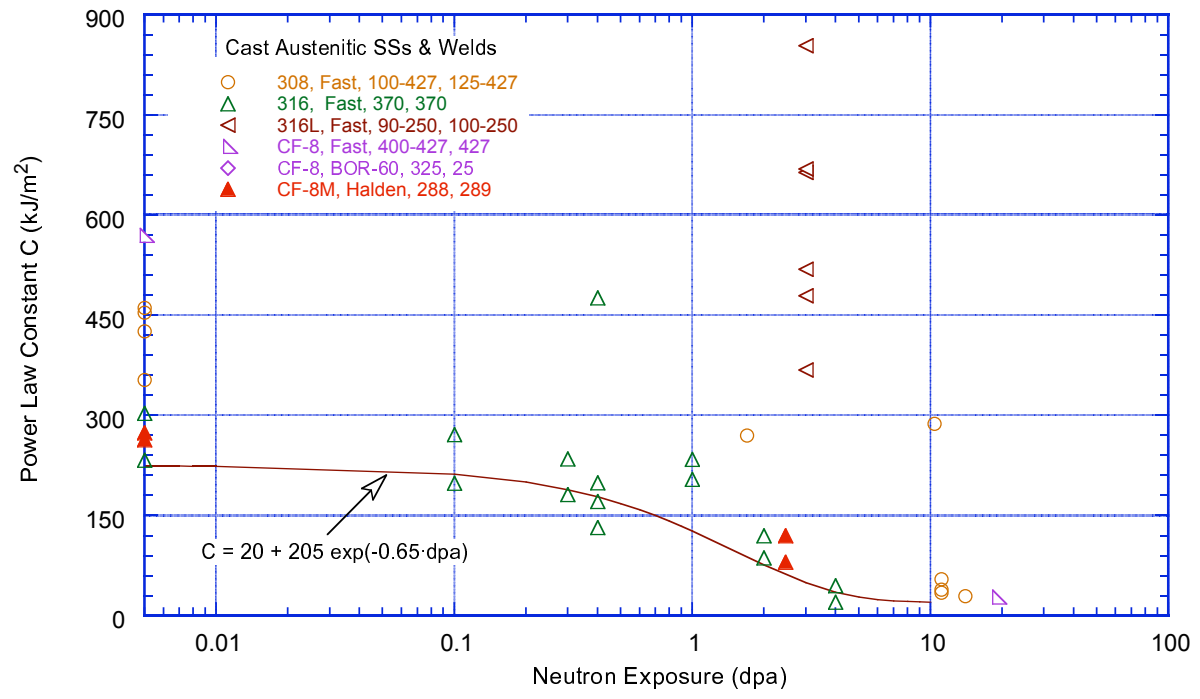

(b)

Figure 75. The change in coefficient $C$ of the power-law J-R curve for (a) wrought austenitic SSs and (b) cast austenitic SSs and weld metals as a function of neutron exposure (in dpa). 
Figure 73a shows that CT specimens of Type $304 \mathrm{SS}$ irradiated to $\approx 4.5 \mathrm{dpa}$ in a BWR (closed circles in Fig. 73a) have very low $\mathrm{J}_{\text {Ic }}$ values [corresponding to $\mathrm{K}_{\mathrm{Ic}}$ of $52-74 \mathrm{MPa} \mathrm{m}{ }^{1 / 2}\left(37-50 \mathrm{ksi} \mathrm{in.}^{1 / 2}\right)$ ] and exhibit no ductile crack extension in the toughness tests. These results indicate that BWR irradiated materials can have very poor fracture toughness, with little or no ductile crack extension, at neutron dose as low as 3-5 dpa. Additional tests on SSs irradiated to 3-10 dpa are needed to validate these results.

Ductile crack extension was also not observed for some specimens of a $20 \% \mathrm{CW}$ Type $316 \mathrm{SS}$ irradiated to $74-88 \mathrm{dpa}$ in a fast reactor at $410-425^{\circ} \mathrm{C}\left(770-797^{\circ} \mathrm{F}\right)$; the $\mathrm{K}_{\mathrm{Ic}}$ values were $74-90 \mathrm{MPa} \mathrm{m}^{1 / 2}$ (67-82 ksi in. $\left.{ }^{1 / 2}\right)$. However, the specimens failed by a quasi-cleavage fracture believed to be an indirect consequence of the onset of void swelling in the material.

The exponent $\mathrm{n}$ of the power law curve typically ranges from 0.35 to 0.70 for nonirradiated materials and 0.16 to 0.65 for irradiated materials. No obvious trend of $\mathrm{n}$ with fluence is evident. For irradiated materials, the median value is 0.37 .

\subsubsection{Fracture Toughness Trend Curve}

A fracture toughness trend curve that bounds the existing data has been developed. It includes (a) a threshold neutron exposure for radiation embrittlement of austenitic SSs and a minimum fracture toughness for these materials irradiated to less than the threshold value, (b) a saturation neutron exposure and a saturation fracture toughness for materials irradiated to greater than this value, and (c) a description of the change in fracture toughness between the threshold and saturation neutron exposures. For fluences less than $5 \mathrm{dpa}$, as shown in Fig. 73, a fracture toughness trend curve that bounds the existing fracture toughness data for $\mathrm{J}_{\mathrm{Ic}}$ as a function of neutron exposure in dpa may be represented by

$$
\mathrm{J}_{\mathrm{Ic}}=9+120 \exp (-0.6 \mathrm{dpa}) \text {. }
$$

A fracture toughness J-R curve may be used to analyze behavior beyond $\mathrm{J}_{\text {Ic }}$. The curve is expressed in terms of the $J$ integral and crack extension $(\Delta \mathrm{a})$ by the power law $J=C(\Delta a)^{n}$. For fluences less than 5 dpa, as shown in Fig. 75, the existing fracture toughness data can be bounded by a power-law J-R curve with coefficient $\mathrm{C}$ expressed as

$$
\mathrm{C}=20+205 \exp (-0.65 \mathrm{dpa})
$$

and an exponent $\mathrm{n}$ equal to 0.37 (the median value of the experimental data). This equation yields a bounding $\mathrm{C}$ value of $\approx 225 \mathrm{~kJ} / \mathrm{m}^{2}$ (1285 in.-lb/in. ${ }^{2}$ ) for materials irradiated to less than $0.5 \mathrm{dpa}$ and $\approx 28 \mathrm{~kJ} / \mathrm{m}^{2}\left(\approx 160\right.$ in. $\left.-1 \mathrm{~b} / \mathrm{in}^{2}{ }^{2}\right)$ for materials irradiated to $\approx 5 \mathrm{dpa}$.

Although the toughness of welds and cast SS is somewhat less than that of wrought materials, Fig. 75 shows that the proposed trend curves also provide an adequate description of the toughness of these materials.

An Electric Power Research Institute (EPRI) report on thermal aging embrittlement of cast SS components proposed using the fracture toughness $\mathrm{J}$ at a crack extension of $2.5 \mathrm{~mm}\left(0.1 \mathrm{in}\right.$.), $\mathrm{J}_{2.5}$, to differentiate between nonsignificant and potentially significant reductions in fracture toughness of cast austenitic SSs. ${ }^{64}$ Flaw tolerance evaluations were presented in Appendices A and B of the EPRI report to support the choice of a threshold value of $J_{2.5}=255 \mathrm{~kJ} / \mathrm{m}^{2}$ (1456 in.-lb/in. ${ }^{2}$ ). The NRC staff has found that using $\mathrm{J}_{2.5}=255 \mathrm{~kJ} / \mathrm{m}^{2}$ is an acceptable screening approach for fracture toughness of cast SSs. ${ }^{65}$ For the coefficient $\mathrm{C}$ data shown in Fig. 75 for wrought and cast austenitic SSs and welds, the experimental 


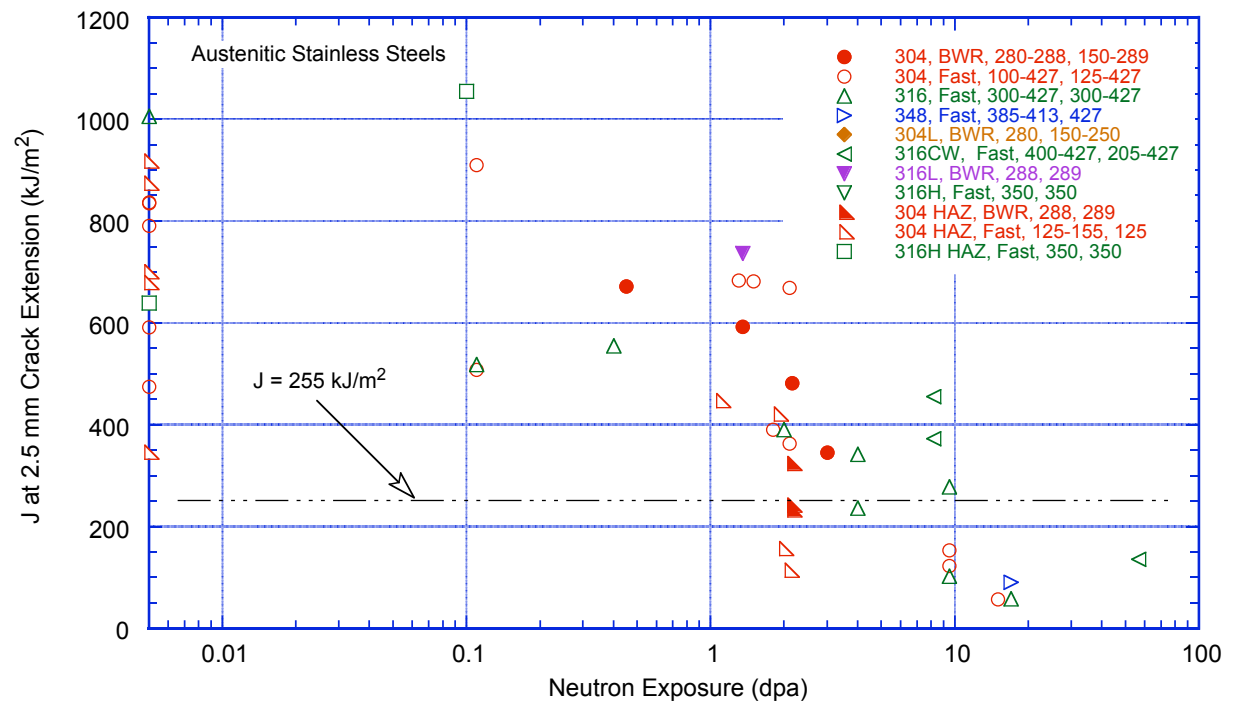

(a)

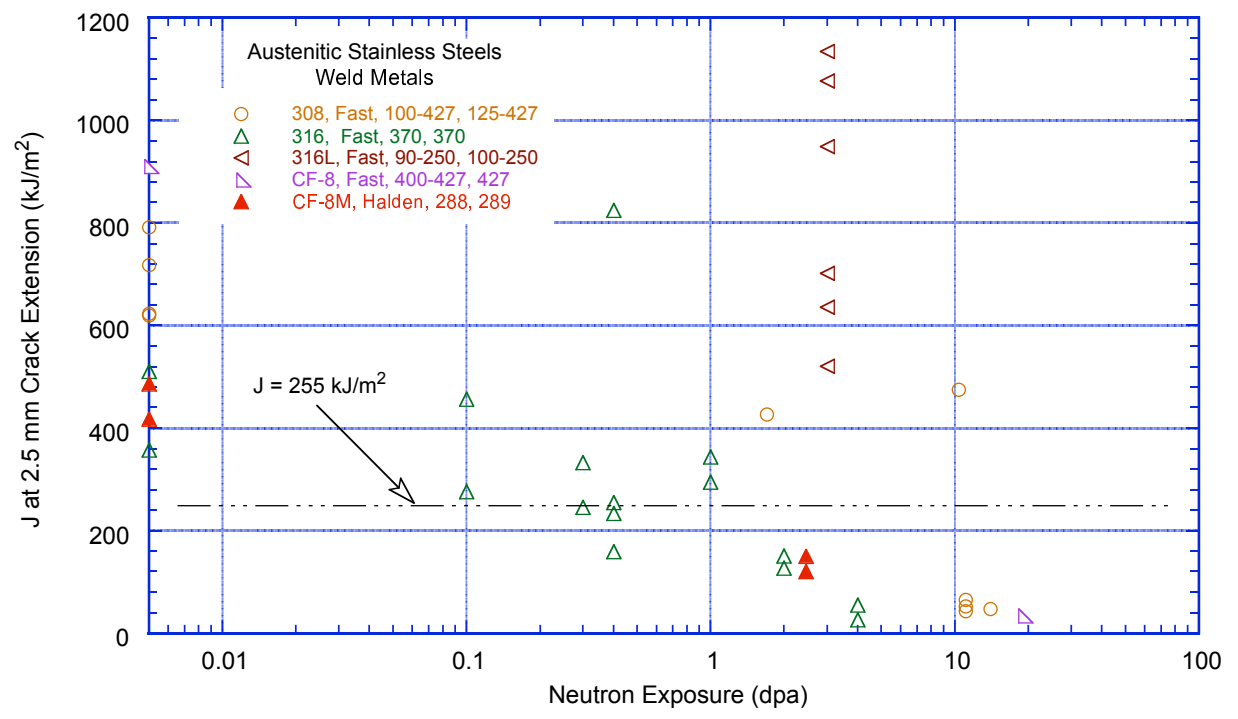

(b)

Figure 76. Experimental values of J-integral at a crack extension of $2.5 \mathrm{~mm}$ for (a) wrought austenitic SSs and (b) cast austenitic SSs and weld metals plotted as a function of neutron exposure. The legend gives the grade of material, irradiation source (in fast reactor or LWR), and irradiation and test temperatures.

J-integral values at a crack extension of $2.5 \mathrm{~mm}$ are plotted as a function of neutron exposure in Fig. 76 . The results indicate that the value of $\mathrm{J}_{2.5}$ for austenitic SSs and welds irradiated up to $0.3 \mathrm{dpa}$ is above the screening value of $255 \mathrm{~kJ} / \mathrm{m}^{2}$ (1456 in.-lb/in. ${ }^{2}$ ). However, the applicability of the flaw tolerance evaluations in Appendices A and B of the EPRI report would have to be demonstrated to support the use of the $\mathrm{J}_{2.5}$ parameter for evaluating the toughness of irradiated materials.

\subsubsection{Synergistic Effect of Thermal and Neutron Irradiation}

Thermal aging of cast austenitic SSs at reactor operating temperatures of $280-350^{\circ} \mathrm{C}\left(536-662^{\circ} \mathrm{F}\right)$ can lead to degradation of the fracture properties of these materials, depending on the characteristics of the material and the environment to which they are exposed. ${ }^{28-30}$ Thermal aging increases the tensile 
strength, hardness, and Charpy-impact transition temperature, and it decreases the ductility, fracture toughness, and impact strength. The extent of mechanical-property degradation is essentially determined by the chemical composition of the steel, the casting process used to construct the component, the ferrite content and ferrite morphology of the steel, and the time and temperature of service for the component. Cast SSs with high levels of Mo (e.g., CF-8M) show greater susceptibility to thermal embrittlement than steels with low Mo content (e.g., CF-3 or CF-8). Also, static cast steels are more susceptible to thermal embrittlement than centrifugally cast components.

As part of the evaluation of passive, long-lived reactor structures for license renewal, the NRC staff has proposed screening criteria to determine the susceptibility of cast SS components to thermal aging embrittlement; ${ }^{65}$ the criteria are outlined in Table 16. For components found or assumed to be potentially susceptible, an aging management program is required for the license renewal period. However, for reactor core internal components, concurrent exposure to neutron irradiation can result in a synergistic effect wherein the service-degraded fracture toughness can be less than that predicted for either of these processes independently.

Table 16. Screening criteria for thermal-aging susceptibility of cast austenitic stainless steels.

\begin{tabular}{c|c|c|c}
\hline Mo Content (wt.\%) & Casting Method & Ferrite Content & Susceptibility Determination \\
\hline High (2.0-3.0) & Static & $\leq 14 \%$ & Not susceptible \\
\cline { 2 - 3 } & & $>14 \%$ & Potentially susceptible \\
\cline { 2 - 3 } & Centrifugal & $\leq 20 \%$ & Not susceptible \\
\cline { 2 - 3 } & & $>20 \%$ & Potentially susceptible \\
\hline \multirow{2}{*}{ Low (0.5 max.) } & Static & $\leq 20 \%$ & Not susceptible \\
& & $>20 \%$ & Potentially susceptible \\
\cline { 2 - 3 } & Centrifugal & All & Not susceptible \\
\hline
\end{tabular}

In the proposed resolution regarding the issue of thermal aging embrittlement of cast SS components, ${ }^{65}$ the NRC staff recommends that, to account for the synergistic loss of fracture toughness, "a program should be implemented consisting of either a supplemental examination of the affected components as part of the applicant's 10-year inservice inspection program during the license renewal term, or a component-specific evaluation to determine the susceptibility to loss of fracture toughness." The component-specific evaluation is based on the neutron fluence. The current guidance ${ }^{65}$ suggests that, if the fluence is greater than $1 \times 10^{17} \mathrm{n} / \mathrm{cm}^{2}(\mathrm{E}>1 \mathrm{MeV}$ ) (or $0.00015 \mathrm{dpa}$ ) for a component, a mechanical loading assessment should be conducted to determine whether a supplemental inspection program is required for the component.

It is useful to consider the potential effects of irradiation in terms of its effect on the rate of embrittlement and on the minimum value of toughness that can occur after long-term thermal aging. Formation of Cr-rich $\alpha^{\prime}$ phase in the ferrite is the primary mechanism for thermal embrittlement of cast austenitic SSs; ${ }^{28-36}$ thermal aging has little or no effect on the austenite phase. Embrittlement of ferrite phase from neutron irradiation occurs at lower fluences than does embrittlement of the austenite phase. A shift in the NDT temperature of up to $150^{\circ} \mathrm{C}\left(302^{\circ} \mathrm{F}\right)$ has been observed in pressure vessel steels irradiated to 0.07-0.15 dpa. ${ }^{37}$ As discussed in Section 4.3.1, any significant effect of neutron irradiation on embrittlement of the austenite phase occurs only above $\approx 0.5$ dpa (see Figs. 73 and 75 ).

The minimum value of fracture toughness that can occur due to thermal embrittlement depends primarily on the ferrite content and morphology. A globular ferrite morphology in which the brittle ferrite phase is isolated in an austenitic matrix will have a higher toughness than a lacy morphology where a more continuous path through the brittle ferrite is possible. The minimum toughness due to thermal aging occurs when the ferrite is fully embrittled, and the remaining toughness depends on the toughness 
provided by the ductile matrix surrounding the embrittled phase. Based on an ANL study, ${ }^{28}$ the predicted saturation fracture toughness J-R curves for the various cast materials in the thermally aged condition (i.e., the lowest fracture toughness that could be achieved for the steel after thermal aging) are expressed as $\mathrm{J} \approx 264 \Delta \mathrm{a}^{0.35}, \approx 251 \Delta \mathrm{a}^{0.34}$, and $\approx 167 \Delta \mathrm{a}^{0.31}$, respectively, for CF-3, CF-8, and CF-8M steels at $290^{\circ} \mathrm{C}\left(554^{\circ} \mathrm{F}\right)$.

For fluences greater than $1.5 \times 10^{-4} \mathrm{dpa}$, but less than $\approx 0.5 \mathrm{dpa}$, irradiation is expected to affect the rate at which cast SSs embrittle, because the ferrite phase is being embrittled both by thermal aging and radiation damage. However, the minimum toughness after long thermal aging would be similar to that observed in the nonirradiated case since the toughness of the austenitic phase does not change. For fluences greater than $\approx 0.5 \mathrm{dpa}$, the minimum toughness will be lower than can be achieved by thermal aging alone, since both the ferrite and the austenitic phases are embrittled.

No data are available in the open literature to quantify the effect of irradiation on the rate of embrittlement, and only very limited data are available to assess the effect of irradiation on the minimum toughness. The data developed in this program were obtained on a CF-8M steel that was thermally aged for $10,000 \mathrm{~h}$ at $400^{\circ} \mathrm{C}$ and then irradiated to well above the threshold fluence. The resulting toughness is bounded by the curve for other SSs irradiated to a similar level, i.e., thermal aging doesn't seem to lower the toughness below that expected for irradiation alone at these fluences. Based on these very limited data and the general mechanism of embrittlement for cast SSs, the minimum fracture toughness of cast SSs can be taken as (a) the minimum predicted toughness for thermal aging for fluences less than $0.3 \mathrm{dpa}$ and (b) the lesser of the minimum predicted toughness for thermal aging or the lower bound curves in Fig. 75 for irradiated SSs. The threshold fluence, taken as $0.3 \mathrm{dpa}$, is a slightly conservative value in light of the limited data and corresponding uncertainty.

The kinetics of thermal aging are reasonably well known. ${ }^{28}$ Irradiation is expected to accelerate the embrittlement of the ferrite phase so the results in Ref. 28 may be nonconservative for fluences greater than $1.5 \times 10^{-4} \mathrm{dpa}$. Additional study and testing are needed to quantify this effect. Additional tests on cast CF-3 and CF-8 steels are also needed to better establish the potential for synergistic loss of toughness in these materials in the transition fluence range from 0.3 to $2 \mathrm{dpa}$. Although cast CF-8M steels are not used in LWR core internal components because of the difficulty of testing irradiated materials, it may be useful to study this material as a "worst-case" material in lieu of testing a number of heats of CF-3 and CF-8. 


\section{Summary}

Crack growth tests have been conducted in BWR environments at $289^{\circ} \mathrm{C}$ on Type $316 \mathrm{SS}$ irradiated to $0.3,0.9$, and $2.0 \times 10^{21} \mathrm{n} / \mathrm{cm}^{2}(0.45,1.35$, and $3.0 \mathrm{dpa})$; sensitized Type $304 \mathrm{SS}$ and SS weld HAZ materials irradiated to $1.44 \times 10^{21} \mathrm{n} / \mathrm{cm}^{2}(2.16 \mathrm{dpa})$; and CF- $8 \mathrm{M}$ cast SS irradiated to $1.63 \times 10^{21} \mathrm{n} / \mathrm{cm}^{2}$ $(2.46 \mathrm{dpa})$. The CGR tests on materials irradiated to 2.16 or $2.46 \mathrm{dpa}$ were followed by a fracture toughness J-R curve test in the BWR environment. Fracture toughness tests have also been conducted in air at $289^{\circ} \mathrm{C}$ to obtain baseline data. The weld HAZ specimens were obtained from a Type 304L SA weld and a Type 304 SS SMA weld. Also compiled in this report are crack growth rate data from earlier ANL studies on Types $304 \mathrm{~L}$ and $316 \mathrm{~L}$ SS irradiated to $0.45,1.35$, and 3.0 dpa and SS weld HAZ materials irradiated to $5 \times 10^{20} \mathrm{n} / \mathrm{cm}^{2}(0.75 \mathrm{dpa})$ in BWR environments, as well as fracture toughness data on Types 304 and $316 \mathrm{~L} \mathrm{SS}$ irradiated up to $2 \times 10^{21} \mathrm{n} / \mathrm{cm}^{2}(3.0 \mathrm{dpa})$ in air at $289^{\circ} \mathrm{C}$. The results from the ANL study are compared with the data available in the literature.

The results indicate that in an NWC BWR environment, the constant-load CGRs (i.e., under SCC loading) of nonirradiated SSs or materials irradiated to $\approx 3 \times 10^{20} \mathrm{n} / \mathrm{cm}^{2}(\approx 0.45 \mathrm{dpa})$ are either comparable to or slightly lower than the disposition curve in NUREG-0313 for sensitized SSs in water with 8 ppm DO. Neutron irradiation increases the CGRs significantly. The CGRs of austenitic SSs irradiated to $5 \times 10^{20}-2.67 \times 10^{21} \mathrm{n} / \mathrm{cm}^{2}(0.75-4.0 \mathrm{dpa})$ are a factor of 2-7 higher than the NUREG-0313 disposition curve. For these irradiation dose levels, the CGRs of austenitic SSs can be represented by a curve that is a factor of 6 higher than the NUREG-0313 disposition curve. A different SCC behavior is observed for austenitic SSs irradiated to higher neutron dose. The CGRs of SSs irradiated to 13 dpa show a strong dependence on $\mathrm{K}$ and are up to a factor of 30 higher than the NUREG-0313 disposition curve for nonirradiated SSs.

The results also indicate a benefit from a low-DO environment. In general, the CGRs of nonirradiated SSs and steels irradiated up to 4.0 dpa decreased more than an order of magnitude when the DO level was decreased from the NWC to the HWC BWR environment. The beneficial effect of low corrosion potential (i.e., HWC chemistry) is not observed for steels irradiated to $8.67 \times 10^{21} \mathrm{n} / \mathrm{cm}^{2}$ (13.0 dpa) or similar high fluences, and a determination of the maximum fluence level for which HWC is effective would be of great interest.

In the current tests a few specimens, irradiated to $\approx 2 \times 10^{21} \mathrm{n} / \mathrm{cm}^{2}(\approx 3.0 \mathrm{dpa})$, did not show the benefit of the low-DO environment. It is not clear if specimen constraint had been lost for these specimens; the adequacy of the proposed $\mathrm{K} /$ size criterion is not well-established. A loss of specimen constraint is also likely to influence the fracture mode and morphology. For example, if the thickness criterion is exceeded, the crack plane, typically, is out-of-normal near the edges of the specimen, and if the specimen ligament criterion is exceeded the crack propagates away from the normal plane at an angle of $45^{\circ}$. No fractographic indication of a change in fracture morphology due to a loss in specimen constraint, however, was evident in the test specimens that did not show the benefit of HWC. The fracture planes were straight and normal to the stress axis. In these specimens, although the specimen $\mathrm{K} /$ size criterion was exceeded in high-DO water, the expected increase in growth rate was not observed. The loading conditions seemed to have had no effect on the growth rates until the DO level in the environment was decreased. Additional tests and analyses are needed to ensure that the unusually high growth rates, or the lack of a benefit of HWC on growth rates, in these irradiated austenitic SSs were not caused by processes other than the loss of specimen constraint due to high loads. 
The limited data on SS weld HAZ materials indicate that neutron irradiation to $\approx 1.47 \times 10^{21} \mathrm{n} / \mathrm{cm}^{2}$ $(\approx 2.2 \mathrm{dpa})$ has little or no effect on cyclic CGRs in air. The experimental CGRs are slightly lower than those predicted by the correlations developed by James and Jones for solution-annealed SSs.

In the NWC BWR environment, the cyclic CGRs of SSs irradiated to $\approx 3 \times 10^{20} \mathrm{n} / \mathrm{cm}^{2}(\approx 0.45 \mathrm{dpa})$ are the same as those for nonirradiated materials, whereas the CGRs of SSs irradiated to $5 \times 10^{20}$ $2.67 \times 10^{21} \mathrm{n} / \mathrm{cm}^{2}(0.75-4.0 \mathrm{dpa})$ are higher. Limited data indicate that the growth rates of irradiated CF-8M cast SS and Type 304L SS weld HAZ material are lower than those of wrought materials irradiated to the same neutron dose. The cyclic CGRs at low frequencies are decreased by more than an order of magnitude when the DO level is decreased by changing from NWC to HWC. A superposition model has been used to represent the cyclic CGRs of austenitic SSs. The CGR in the environment is expressed as the superposition of the rate in air (mechanical fatigue) and the rates due to corrosion fatigue and SCC. The correlations for the various material and environmental conditions are listed in Table 17.

Table 17. Cyclic CGR correlations for wrought and cast austenitic stainless steels in BWR environments at $289^{\circ} \mathrm{C}$.

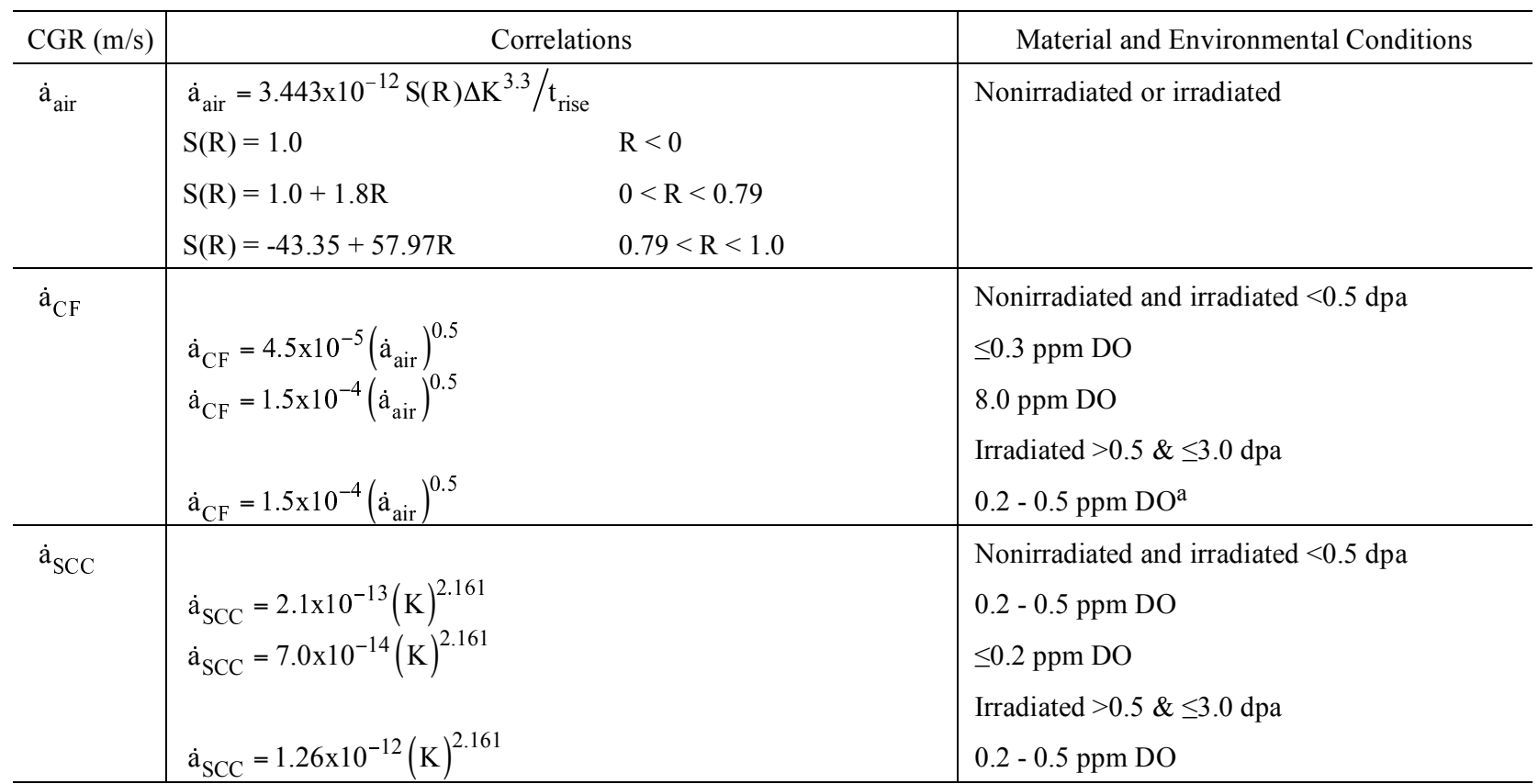

${ }^{\mathrm{a} C}$ Correlation may yield conservative estimates of CGR for cast austenitic SSs and low-C Type 304L SS weld HAZ materials.

Neutron irradiation decreases the fracture toughness of wrought and cast austenitic SSs. For the same irradiation conditions, fracture toughness of the weld HAZ materials is lower than that of the solution-annealed materials, and the toughness of the thermally aged cast SS is lower than that of the HAZ material. Limited data on irradiated SS weld HAZ materials indicate that an NWC BWR environment has little or no effect on their fracture toughness J-R curves. In addition, the fracture toughness J-R curves in air and BWR environments are comparable. Similar tests in air and water environments have not been conducted on irradiated wrought or cast SSs. In the present study, large load drops were observed at the onset of crack extension during the two tests on thermally aged and irradiated CF-8M cast SS. Such load drops, typically, are not observed during J-R curve tests in air. Additional tests on the fracture toughness of wrought and cast SSs are needed to investigate the possible effects of an IG starter crack compared to the TG fatigue crack generally used in nearly all the fracture toughness tests and the corrosion/oxidation reaction during crack extension. 
The available fracture toughness data in the open literature on wrought and cast austenitic SSs and their welds have been reviewed. Most of the experimental data on neutron embrittlement of austenitic SSs have been obtained in high flux fast reactors; similar test results that are relevant to LWRs are very limited. Summarized in this report are the effects of neutron irradiation on the fracture toughness of these steels, as well as the effects of material and irradiation conditions and test temperature.

The existing fracture toughness data on austenitic SSs indicate little or no change in toughness below $3.3 \times 10^{20} \mathrm{n} / \mathrm{cm}^{2}(0.5 \mathrm{dpa})$, rapid decrease between $6.6 \times 10^{20}$ and $3.3 \times 10^{21} \mathrm{n} / \mathrm{cm}^{2}$ (1 and $\left.5 \mathrm{dpa}\right)$ to reach a saturation toughness value, and no further change beyond $6.6 \times 10^{21} \mathrm{n} / \mathrm{cm}^{2}(10 \mathrm{dpa})$. In general, the data trend appears to be similar for the fast reactor and LWR irradiations. There are no apparent differences in the fracture toughness data trends for the various grades of wrought austenitic SSs. In general, the fracture toughness of nonirradiated solution-annealed materials is relatively high, but it decreases rapidly with increasing neutron exposure above $1 \mathrm{dpa}$ and reaches a saturation value beyond $10 \mathrm{dpa}$. For cold-worked SSs, although the fracture toughness of nonirradiated materials is lower than that of solution-annealed steels, the decrease with neutron exposure is slower, and the saturation toughness is higher. The fracture toughness of nonirradiated weld metals and thermally aged cast SSs is also lower, but it decreases more rapidly than that for solution-annealed steels. For example, the fracture toughness for Type $316 \mathrm{SS}$ welds appears to saturate at $2.67 \times 10^{21}$ or $3.3 \times 10^{21} \mathrm{n} / \mathrm{cm}^{2}(4$ or $5 \mathrm{dpa})$.

Both irradiation and test temperature can influence fracture toughness. Available data for austenitic SSs indicate that irradiation hardening is the highest, and ductility loss is maximum at $\approx 300^{\circ} \mathrm{C}\left(572^{\circ} \mathrm{F}\right)$. Also, the fracture toughness of austenitic SSs is known to decrease as the test temperature is increased. Steels irradiated to less than $3.3 \times 10^{21} \mathrm{n} / \mathrm{cm}^{2}(5 \mathrm{dpa})$ show a similar behavior. However, for irradiation levels of $8 \times 10^{21} \mathrm{n} / \mathrm{cm}^{2}(12 \mathrm{dpa})$ or greater, test temperature has little or no effect on fracture toughness.

The existing fracture toughness data have been evaluated to define (a) the threshold neutron exposure for radiation embrittlement of austenitic SSs and the minimum fracture toughness of austenitic SSs irradiated to less than the threshold value, (b) the saturation neutron exposure and the saturation fracture toughness of these materials, and (c) the change in fracture toughness between the threshold and saturation neutron exposures. The results indicate that fracture toughness properties $\left(\mathrm{J}_{\mathrm{Ic}}\right.$ and $\mathrm{J}-\mathrm{R}$ curve $)$ exhibit (a) a threshold neutron dose of $\approx 2 \times 10^{20} \mathrm{n} / \mathrm{cm}^{2}(\approx 0.3 \mathrm{dpa})$ below which irradiation has little or no effect on fracture toughness and (b) a saturation neutron dose of $\approx 3.3 \times 10^{21} \mathrm{n} / \mathrm{cm}^{2}(\approx 5 \mathrm{dpa})$. Conservatively, no ductile crack extension is assumed to occur at or above the saturation neutron dose. The available data indicate a $\mathrm{K}_{\mathrm{Ic}}$ of $50 \mathrm{MPa} \mathrm{m}{ }^{1 / 2}$ [or $\mathrm{J}_{\mathrm{Ic}}$ of $15 \mathrm{~kJ} / \mathrm{m}^{2}\left(86 \mathrm{in} .-\mathrm{lb} / \mathrm{in} .^{2}\right)$ ] for austenitic SSs irradiated to $5 \mathrm{dpa}$. However, the existing data are inadequate to determine whether $\mathrm{K}_{\mathrm{Ic}}$ decreases further at higher neutron dose. A fracture toughness trend curve that bounds the existing data has been defined in terms of $\mathrm{J}_{\mathrm{Ic}}$ vs. neutron dose (in dpa) and coefficient $\mathrm{C}$ of the power-law J-R curve vs. dose.

Potential synergistic effects of thermal and radiation embrittlement of cast austenitic SS internal components have also been evaluated. Such effects could affect both the rate of embrittlement and the degree of embrittlement. Cast austenitic SSs have a duplex structure consisting of both ferrite and austenite phases and are susceptible to thermal embrittlement even in the absence of irradiation. Thermal aging affects primarily the ferrite phase and has little or no effect on the austenite phase. It is estimated that effects on the rate of embrittlement could occur for fluences greater than $1 \times 10^{17} \mathrm{n} / \mathrm{cm}^{2}$ $(0.00015 \mathrm{dpa})$. However, synergistic effects on the minimum toughness would occur only for fluences greater than $2 \times 10^{20} \mathrm{n} / \mathrm{cm}^{2}(0.3 \mathrm{dpa})$. Below $0.3 \mathrm{dpa}$, the minimum toughness can be estimated from the correlations available for thermal embrittlement of cast SS. For fluences $>0.3 \mathrm{dpa}$, the minimum fracture toughness of cast SSs can be assumed to be given by the lesser of the minimum predicted toughness for thermal aging or the lower bound curves for the fracture toughness of irradiated stainless steels. 
This page is intentionally left blank. 


\section{References}

1. Bruemmer, S. M., et al., "Critical Issue Reviews for the Understanding and Evaluation of Irradiation-Assisted Stress Corrosion Cracking," EPRI TR-107159, Electric Power Research Institute, Palo Alto, CA, 1996.

2. Herrera, M. L., et al., "Evaluation of the Effects of Irradiation on the Fracture Toughness of BWR Internal Components," Proc. ASME/JSME 4th Intl. Conf. on Nucl. Eng. (ICONE-4), Vol. 5, A. S. Rao, R. M. Duffey, and D. Elias, eds., American Society of Mechanical Engineers, New York, pp. 245-251, 1996.

3. Mills, W. J., "Fracture Toughness of Type 304 and 316 Stainless Steels and Their Welds," Intl. Mater. Rev. 42, 45-82, 1997.

4. Kanasaki, H., I. Satoh, M. Koyama, T. Okubo, T. R. Mager, and R. G. Lott, "Fatigue and Stress Corrosion Cracking Behaviors of Irradiated Stainless Steels in PWR Primary Water," Proc. 5th Intl. Conf. on Nuclear Engineering, ICONE5-2372, pp. 1-7, 1997.

5. Andresen, P. L., F. P. Ford, S. M. Murphy, and J. M. Perks, "State of Knowledge of Radiation Effects on Environmental Cracking in Light Water Reactor Core Materials," Proc. 4th Intl. Symp. on Environmental Degradation of Materials in Nuclear Power Systems - Water Reactors, NACE, Houston, TX, pp. 1.83-1.121, 1990.

6. Jenssen, A., and L. G. Ljungberg, "Irradiation Assisted Stress Corrosion Cracking of Stainless Alloys in BWR Normal Water Chemistry and Hydrogen Water Chemistry," Proc. Sixth Intl. Symp. on Environmental Degradation of Materials in Nuclear Power Systems - Water Reactor, R. E. Gold and E. P. Simonen, eds., Minerals, Metals \& Materials Society, Warrendale, PA, pp. 547-553, 1993.

7. Maziasz, P. J., and C. J. McHargue, "Microstructural Evolution in Annealed Austenitic Steels during Neutron Irradiation,” Int. Met. Rev. 32, 190, 1987.

8. Maziasz, P. J., "Overview of Microstructural Evolution in Neutron-Irradiated Austenitic Stainless Steels,” J. Nucl. Mater. 205, 118-145, 1993.

9. Garner, F. A., "Evolution of Microstructures in Face-Centered Cubic Metals during Neutron Irradiation,” J. Nucl. Mater. 205, 98-111, 1993.

10. Lucas, G. E., "The Evolution of Mechanical Property Change in Irradiated Austenitic Stainless Steels,” J. Nucl. Mater. 206, 287-305, 1993.

11. Dufresne, J., B. Henry, and H. Larsson, "Fracture Toughness of Irradiated AISI 304 and 316L Stainless Steels," Effects of Radiation on Structural Materials, ASTM STP 683, J. A. Sprague and D. Kramer, eds., American Society for Testing and Materials, Philadelphia, PA, pp. 511-528, 1979.

12. Picker, C., A. L. Stott, and H. Cocks, "Effects of Low-Dose Fast Neutron Irradiation on the Fracture Toughness of Type 316 Stainless Steel and Weld Metal," Proc. Specialists Meeting on Mechanical Properties of Fast Reactor Structural Materials, Chester, UK, Paper IWGFR 49/440-4, 1983. 
13. Huang, F. H., "The Fracture Characterization of Highly Irradiated Type 316 Stainless Steel," Int. J. Fracture 25, 181-193, 1984.

14. Bernard, J., and G. Verzeletti, "Elasto-Plastic Fracture Mechanics Characterization of Type 316H Irradiated Stainless Steel up to 1 dpa," Effects of Radiation on Materials: 12th Intl. Symp., ASTM STP 870, F. A. Garner and J. S. Perrin, eds., American Society for Testing and Materials, Philadelphia, PA, pp. 619-641, 1985.

15. Mills, W. J., L. A. James, and L. D. Blackburn, "Results of Fracture Mechanics Tests on PNC SU 304 Plate," Westinghouse Hanford Report HEDL-7544, Hanford Engineering Development Laboratory, Richland, WA, 1985.

16. Mills, W. J., "Fracture Toughness of Irradiated Stainless Steel Alloys,” Nucl. Technol. 82, 290-303, 1988.

17. Michel, D. J., and R. A. Gray, "Effects of Irradiation on the Fracture Toughness of FBR Structural Materials,” J. Nucl. Mater. 148, 194-203, 1987.

18. Ould, P., P. Balladon, and Y. Meyzaud, Bull. Cercle Etud. Metaux 15, 31.1-31.12, 1988.

19. Van Osch, E. V., M. G. Horsten, and M. I. De Vries, "Fracture Toughness of PWR Internals," ECN Contribution to CEC Contract on PWR Internals-Part 2 (ETNU/CT/94/0136-F), ECN-I-97-010 (71747/NUC/EvO/mh/006274), Netherlands Energy Research Foundation ECN, Petten, the Netherlands, 1997.

20. De Vries, M. I., "Fatigue Crack Growth and Fracture Toughness Properties of Low Fluence Neutron-Irradiated Type 316 and Type 304 Stainless Steels," Influence of Radiation on Mechanical Properties: 13th Symposium (Part II), ASTM STP 956, F. A. Garner et al., eds., American Society of Testing and Materials, Philadelphia, PA, pp. 174-190, 1987.

21. Alexander, D. J., J. E. Pawel, L. M. Grossbeck, A. F. Rowcliffe, and K. Shiba, "Fracture Toughness of Irradiated Candidate Materials for ITER First Wall/Blanket Structures," Effect of Radiation on Materials: 17th Intl. Symp., ASTM STP 1270, American Society of Testing and Materials, Philadelphia, PA, pp. 945-970, 1996.

22. Sindelar, R. L., G. R. Caskey, Jr., J. K. Thomas, J. R. Hawthorne, A. L. Hiser, R. A. Lott, J. A. Begley, and R. P. Shogan, "Mechanical Properties of 1950s Vintage Type 304 Stainless Steel Weldment Components after Low Temperature Neutron Irradiation," 16th Intl. Symp. on Effects of Radiation on Materials, ASTM STP 1175, American Society of Testing and Materials, Philadelphia, PA, pp. 714-746, 1993.

23. Hamilton, M. L., F. H. Huang, W. J. S. Yang, and F. A. Garner, "Mechanical Properties and Fracture Behavior of $20 \%$ Cold-Worked 316 Stainless Steel Irradiated to Very High Neutron Exposures," Influence of Radiation in Material, Properties: 13th Intl. Symp. (Part II), ASTM STP 956, American Society of Testing and Materials, Philadelphia, PA, pp. 245-270, 1987.

24. Little, E. A., "Dynamic J-Integral Toughness and Fractographic Studies of Fast Reactor Irradiated Type 321 Stainless Steel," Effects of Radiation on Material, Properties: 12th Intl. Symp., ASTM STP 870, American Society of Testing and Materials, Philadelphia, PA, pp. 563-579, 1985. 
25. Haggag, F. J., W. L. Server, W. G. Reuter, and J. M. Beeston, "Effects of Irradiation Fluence and Creep on Fracture Toughness of Type 347/348 Stainless Steels," ASTM STP 870, American Society of Testing and Materials, Philadelphia, PA, pp. 548-562, 1985.

26. O'Donnell, I. J., H. Huthmann, and A. A. Tavassoli, "The Fracture Toughness Behaviour of Austenitic Steels and Weld Metal Including the Effects of Thermal Aging and Irradiation," Intl. J of Pressure Vessels and Piping 65 (3), 209-220, 1996.

27. Chopra, O. K., E. E. Gruber, and W. J. Shack, "Fracture Toughness and Crack Growth Rates of Austenitic Stainless Steels,” NUREG/CR-6826, ANL-03/22, 2004.

28. Chopra, O. K., "Estimation of Fracture Toughness of Cast Stainless Steels during Thermal Aging in LWR Systems,” NUREG/CR-4513 Rev. 1, ANL-93/22, 1994.

29. Chopra, O. K. and W. J. Shack, "Mechanical Properties of Thermally Aged Cast Stainless Steels from Shippingport Reactor Components,” NUREG/CR-6275, 1995.

30. Gavenda, D. J., W. F. Michaud, T. M. Galvin, W. F. Burke, and O. K. Chopra, "Effects of Thermal Aging on Fracture Toughness and Charpy-Impact Strength of Stainless Steel Pipe Welds," NUREG/CR-6428, ANL-95/47, 1996.

31. Bonnet, S., J. Bourgoin, J. Champredonde, D. Guttmann, and M. Guttmann, "Relationship between Evolution of Mechanical Properties of Various Cast Duplex Stainless Steels and Metallurgical and Aging Parameters: An Outline of Current EdF Programmes," Mater. Sci. Technol. 6, 221-229, 1990.

32. Slama, G., P. Petrequin, and T. Mager, "Effect of Aging on Mechanical Properties of Austenitic Stainless Steel Castings and Welds," SMiRT Post-Conference Seminar 6, Assuring Structural Integrity of Steel Reactor Pressure Boundary Components, Aug. 29-30, 1983, Monterey, CA, 1983.

33. Chung, H. M., and O. K. Chopra, "Kinetics and Mechanism of Thermal Aging Embrittlement of Duplex Stainless Steels," Environmental Degradation of Materials in Nuclear Power Systems Water Reactors, G. J. Theus and J. R. Weeks, eds., The Metallurgical Society, Warrendale, PA, pp. 359-370, 1988.

34. Auger, P., F. Danoix, A. Menand, S. Bonnet, J. Bourgoin, and M. Guttmann, "Atom Probe and Transmission Electron Microscopy Study of Aging of Cast Duplex Stainless Steels," Mater. Sci. Technol. 6, 301-313, 1990.

35. Brown, J. E., A. Cerezo, T. J. Godfrey, M. G. Hetherington, and G. D. W. Smith, "Quantitative Atom Probe Analysis of Spinodal Reaction in Ferrite Phase of Duplex Stainless Steel," Mater. Sci. Technol. 6, 293-300, 1990.

36. Miller, M. K., and J. Bentley, "Characterization of Fine-Scale Microstructures in Aged Primary Coolant Pipe Steels," Environmental Degradation of Materials in Nuclear Power Systems - Water Reactors, G. J. Theus and J. R. Weeks, eds., The Metallurgical Society, Warrendale, PA, pp. 341$349,1988$. 
37. Hawthorne, J. R., and L. E. Steele, "Metallurgical Variables as Possible Factors Controlling Irradiation Response of Structural Steels," Effects of Radiation on Structural Metals, ASTM STP 426, American Society of Testing and Materials, Philadelphia, PA, pp. 534-572, 1967.

38. Brown, K. S., and G. M. Gordon, "Effects of BWR Coolant Chemistry on the Propensity for IGSCC Initiation and Growth in Creviced Reactor Internals Components," Proc. Third Intl. Symp. on Environmental Degradation of Materials in Nuclear Power Systems - Water Reactor, The Metallurgical Society, Warrendale, PA, pp. 243-248, 1987.

39. Gordon, G. M., and K. S. Brown, "Dependence of Creviced BWR Component IGSCC Behavior on Coolant Chemistry," Proc. 4th Intl. Symp. on Environmental Degradation of Materials in Nuclear Power Systems - Water Reactor, Daniel Cubicciotti, ed., NACE, Houston, TX, pp. 14.46-14.61, 1990.

40. Garzarolli, F., D. Alter, and P. Dewes, "Deformability of Austenitic Stainless Steels and NickelBase Alloys in the Core of a Boiling and a Pressurized Water Reactor," Proc. Intl. Symp. on Environmental Degradation of Materials in Nuclear Power Systems - Water Reactor, American Nuclear Society, Lagrange, IL, pp. 131-138, 1986.

41. Kodama, M., et al., "IASCC Susceptibility of Austenitic Stainless Steels Irradiated to High Neutron Fluence," Proc. Sixth Intl. Symp. on Environmental Degradation of Materials in Nuclear Power Systems - Water Reactor, R. E. Gold and E. P. Simonen, eds., Minerals, Metals \& Materials Society, Warrendale, PA, pp. 583-588, 1993.

42. Kodama, M., et al., "Effects of Fluence and Dissolved Oxygen on IASCC in Austenitic Stainless Steels," Proc. Fifth Intl. Symp. on Environmental Degradation of Materials in Nuclear Power Systems - Water Reactor, American Nuclear Society, Lagrange, IL, pp. 948-954, 1991.

43. Clark, W. L., and A. J. Jacobs, "Effect of Radiation Environment on SCC of Austenitic Materials," Proc. First Intl. Symp. on Environmental Degradation of Materials in Nuclear Power Systems Water Reactor, NACE, Houston, TX, p. 451, 1983.

44. Jacobs, A. J., G. P. Wozadlo, K. Nakata, T. Yoshida, and I. Masaoka, "Radiation Effects on the Stress Corrosion and Other Selected Properties of Type-304 and Type-316 Stainless Steels," Proc. Third Intl. Symp. on Environmental Degradation of Materials in Nuclear Power Systems - Water Reactor, The Metallurgical Society, Warrendale, PA, pp. 673-681, 1987.

45. Chung, H. M., R. V. Strain, and R. W. Clark, "Slow-Strain-Rate-Tensile Test of Model Austenitic Stainless Steels Irradiated in the Halden Reactor," in Environmentally Assisted Cracking in Light Water Reactors Semiannual Report July 2000 - December 2000, NUREG/CR-4667, Vol. 31, ANL01/09, pp. 22-32, 2002.

46. Chung, H. M., R. V. Strain, and R. W. Clark, "Slow-Strain-Rate-Tensile Test of Model Austenitic Stainless Steels Irradiated in the Halden Reactor," in Environmentally Assisted Cracking in Light Water Reactors Semiannual Report January-December 2001, NUREG/CR-4667, Vol. 32, ANL-02/33, pp. 19-28, 2003.

47. Andresen, P. L., and F. P. Ford, "Irradiation Assisted Stress Corrosion Cracking: From Modeling and Prediction of Laboratory \& In-Core Response to Component Life Prediction," Corrosion/95, NACE, Houston TX, Paper No. 419, 1995. 
48. Jenssen, A., and L. G. Ljungberg, "Irradiation Assisted Stress Corrosion Cracking: Post Irradiation CERT Tests of Stainless Steels in a BWR Test Loop," Proc. Seventh Intl. Symp. on Environmental Degradation of Materials in Nuclear Power Systems - Water Reactor, G. Airey et al., eds., NACE, Houston, TX, pp. 1043-1052, 1995.

49. Angeliu, T. M., P. L. Andresen, E. Hall, J. A. Sutliff, and S. Sitzman, "Strain and Microstructure Characterization of Austenitic Stainless Steel Weld HAZs," Corrosion/2000, Paper 00186, NACE, Houston, TX, 2000.

50. Angeliu, T. M., P. L. Andresen, J. A. Sutliff, and R. M. Horn, "Intergranular Stress Corrosion Cracking of Unsensitized Stainless Steels in BWR Environments," Proc. Ninth Intl. Symp. on Environmental Degradation of Materials in Nuclear Power Systems - Water Reactor, The Metallurgical Society, Warrendale, PA, pp. 311-318, 1999.

51. Andresen, P. L., T. M. Angeliu, W. R. Catlin, L. M. Young, and R. M. Horn, "Effect of Deformation on SCC of Unsensitized Stainless Steel," Corrosion/2000, Paper 00203, NACE, Houston, TX, 2000.

52. Andresen, P. L., T. M. Angeliu, L. M. Young, W. R. Catlin, and R. M. Horn, "Mechanism and Kinetics of SCC in Stainless Steels," Proc. Tenth Intl. Symp. on Environmental Degradation of Materials in Nuclear Power Systems - Water Reactor, NACE, Houston, TX, 2001.

53. Chung, H. M., and W. J. Shack, "Irradiation-Assisted Stress Corrosion Cracking Behavior of Austenitic Stainless Steels Applicable to LWR Core Internals," NUREG/CR-6892, ANL-04/10, 2006.

54. Chopra, O. K., B. Alexandreanu, E. E. Gruber, R. S. Daum, and W. J. Shack, "Crack Growth Rates of Irradiated Austenitic Stainless Steel Weld Heat Affected Zone in BWR Environments," NUREG/CR-6891, ANL-04/20, 2006.

55. Odette, G. R., and G. E. Lucas, "The Effects of Intermediate Temperature Irradiation on the Mechanical Behavior of 300-Series Austenitic Stainless Steels," J. Nucl. Mater. 179-181, 572-576, 1991.

56. Andresen, P. L., "Similarity of Cold Work and Radiation Hardening in Enhancing Yield Strength and SCC Growth of Stainless Steel in Hot Water," Corrosion/02, NACE, Houston, TX, Paper No. 02509, 2002.

57. Jenssen, A., K. Gott, P. Efsing, and P. O. Andersson, "Crack Growth Behavior of Irradiated Type 304L Stainless Steel in Simulated BWR Environment," Proc. 11th Intl. Symp. on Environmental Degradation of Materials in Nuclear Power Systems - Water Reactor, pp. 10151024, 2003.

58. James, L. A., and D. P. Jones, "Fatigue Crack Growth Correlation for Austenitic Stainless Steels in Air," Proc. Conf. on Predictive Capabilities in Environmentally-Assisted Cracking, PVP Vol. 99, R. Rungta, ed., American Society of Mechanical Engineers, New York, pp. 363-414, 1985.

59. Shack, W. J., and T. F. Kassner, "Review of Environmental Effects on Fatigue Crack Growth of Austenitic Stainless Steels,” NUREG/CR-6176, ANL-94/1, 1994. 
60. Hazelton, W. S., and W. H. Koo, "Technical Report on Material Selection and Processing Guidelines for BWR Coolant Pressure Boundary Piping, Final Report," NUREG-0313, Rev. 2, 1988.

61. Balladon, P., J. Heritier, and P. Rabbe, "Influence of Microstructure on the Ductile Rupture Mechanisms of a 316L Steel at Room and Elevated Temperatures," Fracture Mechanics: 14th Symp., Vol. II: Testing and Applications, ASTM STP 791, American Society for Testing and Materials, Philadelphia, PA, pp. 496-516, 1983.

62. Mills, W. J., "On the Relationship Between Stretch Zone Formation and the J Integral for High Strain-Hardening Materials,” J. of Testing and Evaluation 9, 56-62, 1981.

63. Karlsen, T. M., P. Bennett, and N. W. Hogberg, "In-Core Crack Growth Rate Studies on Irradiated Austenitic Stainless Steels in BWR and PWR Conditions in the Halden Reactor," Proc. 12th Intl. Conf. on Environmental Degradation of Materials in Nuclear Power Systems - Water Reactors, T. R. Allen, P. J. King, and L. Nelson, eds., The Minerals, Metals \& Materials Society, Warrendale, PA, pp. 337-348, 2005.

64. Nickell, R. E., and M. A. Rinckel, "Evaluation of Thermal Aging Embrittlement for Cast Austenitic Stainless Steels Components in LWR Reactor Coolant Systems," EPRI TR-106092, Electric Power Research Institute, Palo Alto, CA, 1997.

65. U.S. Nuclear Regulatory Commission, "Thermal Aging Embrittlement of Cast Austenitic Stainless Steel Components," License Renewal Issue No. 98-0030, U.S. Nuclear Regulatory Commission, May 19, 2000. 
Appendix A 


\section{Appendix A: Crack Growth Rate Data for Irradiated Austenitic SSs}

\section{A.1 Specimen C3-A of Type $304 \mathrm{~L}$ SS Irradiated to $0.45 \mathrm{dpa}$ at $288^{\circ} \mathrm{C}$, Test CGRI-12}

Table A1. Crack growth data for Specimen C3-A of Type 304L SS in BWR water at $289^{\circ} \mathrm{C}$.

\begin{tabular}{|c|c|c|c|c|c|c|c|c|c|c|c|c|c|}
\hline $\begin{array}{c}\text { Test } \\
\text { Period }^{b} \\
\end{array}$ & $\begin{array}{c}\text { Test } \\
\text { Time, } \\
\mathrm{h} \\
\end{array}$ & $\begin{array}{r}\mathrm{E} \\
\mathrm{mV} \\
\mathrm{Pt} \\
\end{array}$ & $\begin{array}{l}\mathrm{P}, \mathrm{c} \\
\text { SHE) } \\
\text { Steel } \\
\end{array}$ & $\begin{array}{c}\mathrm{O}_{2} \\
\text { Conc., } \\
\text { ppb }\end{array}$ & $\begin{array}{c}\text { R } \\
\text { Load } \\
\text { Ratio } \\
\end{array}$ & $\begin{array}{c}\text { Rise } \\
\text { Time, } \\
\mathrm{s} \\
\end{array}$ & $\begin{array}{c}\text { Return } \\
\text { Time, } \\
\mathrm{s} \\
\end{array}$ & $\begin{array}{c}\text { Hold } \\
\text { Time, } \\
\mathrm{s} \\
\end{array}$ & $\begin{array}{c}\mathrm{K}_{\max }, \\
\mathrm{MPa} \mathrm{m}^{1 / 2}\end{array}$ & $\begin{array}{c}\Delta \mathrm{K}, \\
\mathrm{MPa} \mathrm{m} \mathrm{m}^{1 / 2}\end{array}$ & $\begin{array}{c}\text { Growth } \\
\text { Rate, } \\
\mathrm{m} / \mathrm{s}\end{array}$ & $\begin{array}{c}\text { Allowed } \\
\mathrm{K}_{\max },{ }^{\mathrm{d}} \\
\mathrm{MPa} \mathrm{m}^{1 / 2}\end{array}$ & $\begin{array}{c}\text { Crack } \\
\text { Length, } \\
\mathrm{mm}\end{array}$ \\
\hline Pre & 55 & 226 & 167 & 300 & 0.31 & 0.50 & 0.50 & 0 & 12.9 & 8.9 & $2.94 \mathrm{E}-09$ & 18.4 & $\begin{array}{l}6.000 \\
6.037\end{array}$ \\
\hline 1 & 165 & 212 & 166 & 300 & 0.30 & 0.50 & 0.50 & 0 & 14.0 & 9.8 & 8.37E-09 & 17.9 & 6.350 \\
\hline $2 a$ & 189 & 221 & 169 & 300 & 0.50 & 5.00 & 5.00 & 0 & 13.9 & 6.9 & negligible & 17.9 & 6.364 \\
\hline $2 b$ & 193 & 211 & 169 & 300 & 0.50 & 0.50 & 0.50 & 0 & 13.8 & 6.9 & negligible & 17.9 & 6.363 \\
\hline $2 c$ & 214 & 211 & 163 & 300 & 0.30 & 0.50 & 0.50 & 0 & 13.9 & 9.7 & negligible & 17.9 & 6.358 \\
\hline $2 d$ & 219 & 218 & 171 & 300 & 0.30 & 0.50 & 0.50 & 0 & 15.0 & 10.5 & $1.48 \mathrm{E}-08$ & 17.7 & 6.499 \\
\hline 3 & 364 & 218 & 171 & 300 & 0.30 & 1 & 1 & 0 & 15.9 & 11.1 & $1.39 \mathrm{E}-08$ & 17.5 & 6.598 \\
\hline 4 & 380 & 218 & 171 & 300 & 0.30 & 30 & 4 & 0 & 16.0 & 11.2 & $1.33 \mathrm{E}-09$ & 17.4 & 6.663 \\
\hline $5^{*}$ & 404 & 219 & 177 & 300 & 0.29 & 300 & 4 & 0 & 15.9 & 11.3 & $3.29 \mathrm{E}-10$ & 17.4 & 6.690 \\
\hline 6 & 479 & 204 & 173 & 300 & 0.48 & 300 & 4 & 0 & 15.7 & 8.2 & $4.75 \mathrm{E}-11$ & 17.4 & 6.704 \\
\hline 7 & 596 & 235 & 187 & 300 & 0.70 & 12 & 12 & 0 & 15.7 & 4.7 & negligible & 17.4 & 6.704 \\
\hline 8 & 670 & 228 & 188 & 300 & 0.70 & 12 & 12 & 0 & 17.6 & 5.3 & $6.23 \mathrm{E}-11$ & 17.3 & 6.720 \\
\hline 9 & 717 & 231 & 186 & 300 & 0.70 & 12 & 12 & 3600 & 17.9 & - & - & 17.3 & 6.741 \\
\hline $10^{*}$ & 910 & 134 & 197 & 300 & 0.70 & 500 & 12 & 3600 & 17.9 & - & $8.65 \mathrm{E}-11$ & 17.2 & 6.796 \\
\hline 11 & 1080 & 232 & 200 & 300 & 0.70 & 500 & 12 & 3600 & 22.0 & - & $1.11 \mathrm{E}-10$ & 17.1 & 6.873 \\
\hline 12 & 1175 & 226 & 203 & 300 & 0.70 & 500 & 12 & 9500 & 22.3 & - & $1.13 \mathrm{E}-10$ & 17.0 & 6.916 \\
\hline
\end{tabular}

${ }^{\mathrm{a}}$ Heat $\mathrm{C} 3$, irradiated to $0.3 \times 10^{2 \mathrm{~L}} \mathrm{n} / \mathrm{cm}^{2}(0.45 \mathrm{dpa})$ at $\approx 288^{\circ} \mathrm{C}$.

$\mathrm{b}_{\mathrm{An}}$ asterisk indicates environmental enhancement of growth rates under cyclic loading.

${ }^{\mathrm{c}}$ Represents values in the effluent. Conductivity was $\approx 0.07$ and $0.30-0.45 \mu \mathrm{S} / \mathrm{cm}$ in the feedwater and effluent, respectively.

Feedwater $\mathrm{pH}$ at room temperature was 6.5.

${ }^{\mathrm{d}}$ Based on effective flow stress, defined as the average of irradiated and nonirradiated flow stresses.

${ }^{\mathrm{e}}$ The difference between the measured crack extension and that determined from the DC potential drop measurements was $<5 \%$.

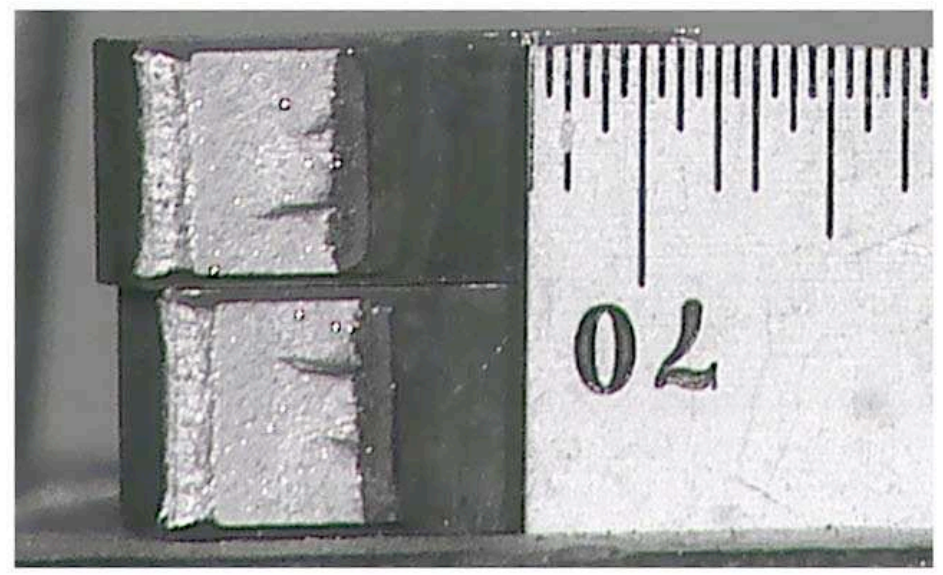

Figure A1.

Photograph of the fracture surfaces of the two halves of the fractured Specimen C3-A. 
A.2 Specimen C3-B of Type 304 L SS Irradiated to $1.35 \mathrm{dpa}$ at $288^{\circ} \mathrm{C}$, Test CGRI-07

Table A2. Crack growth data for Specimen C3-Ba of Type 304L SS in BWR water at $289^{\circ} \mathrm{C}$.

\begin{tabular}{|c|c|c|c|c|c|c|c|c|c|c|c|c|c|}
\hline $\begin{array}{c}\text { Test } \\
\text { Period }^{b}\end{array}$ & $\begin{array}{c}\text { Test } \\
\text { Time, } \\
\mathrm{h}\end{array}$ & $\begin{array}{c}\mathrm{EC} \\
\mathrm{mV} \\
\mathrm{Pt} \\
\end{array}$ & $\begin{array}{l}\mathrm{P}, \mathrm{c} \\
\text { SHE) } \\
\text { Steel } \\
\end{array}$ & $\begin{array}{c}\mathrm{O}_{2} \\
\text { Conc., } \\
\text { ppb }\end{array}$ & $\begin{array}{c}\text { R } \\
\text { Load } \\
\text { Ratio } \\
\end{array}$ & $\begin{array}{c}\text { Rise } \\
\text { Time, } \\
\mathrm{s} \\
\end{array}$ & $\begin{array}{c}\text { Return } \\
\text { Time, } \\
\mathrm{s} \\
\end{array}$ & $\begin{array}{c}\text { Hold } \\
\text { Time, } \\
\text { s } \\
\end{array}$ & $\begin{array}{c}\mathrm{K}_{\max }, \\
\mathrm{MPa} \mathrm{m}^{1 / 2}\end{array}$ & $\begin{array}{c}\Delta \mathrm{K}, \\
\mathrm{MPa} \mathrm{m} \mathrm{m}^{1 / 2}\end{array}$ & $\begin{array}{c}\text { Growth } \\
\text { Rate, } \\
\mathrm{m} / \mathrm{s}\end{array}$ & $\begin{array}{c}\text { Allowed } \\
\mathrm{K}_{\max }{ }^{\mathrm{d}} \\
\mathrm{MPa} \mathrm{m}^{1 / 2}\end{array}$ & $\begin{array}{c}\text { Crack } \\
\text { Length, } \\
\mathrm{mm}\end{array}$ \\
\hline Pron & 2 & 222 & 147 & 300 & 020 & 0.5 & 0.5 & 0 & 187 & 150 & $451 \mathrm{~F} 08$ & 105 & 6.000 \\
\hline Pre $b$ & $\begin{array}{l}2 \\
4\end{array}$ & 223 & $\begin{array}{l}147 \\
148\end{array}$ & 300 & 0.20 & 0.5 & 0.5 & 0 & 17.6 & 14.1 & 4.17E-08 & $\begin{array}{l}19.3 \\
19.2\end{array}$ & $\begin{array}{l}0.188 \\
6.391\end{array}$ \\
\hline Pre c & 23 & - & - & 300 & 0.53 & 30 & 2 & 0 & 16.9 & 7.9 & $1.12 \mathrm{E}-10$ & 19.2 & 6.393 \\
\hline Pre d & 26 & - & - & 300 & 0.20 & 0.5 & 0.5 & 0 & 17.9 & 14.3 & $3.41 \mathrm{E}-08$ & 18.8 & 6.590 \\
\hline 1 & 28 & 230 & 154 & 300 & 0.20 & 0.5 & 0.5 & 0 & 19.1 & 15.3 & $6.83 \mathrm{E}-08$ & 18.4 & 6.817 \\
\hline $2^{*}$ & 172 & 239 & 189 & 300 & 0.51 & 60 & 2 & 0 & 19.0 & 9.3 & $1.75 \mathrm{E}-10$ & 18.3 & 6.873 \\
\hline $3^{*}$ & 287 & 233 & 187 & 300 & 0.70 & 300 & 2 & 0 & 19.8 & 5.9 & $6.38 \mathrm{E}-10$ & 18.0 & 7.046 \\
\hline 4 & 335 & 235 & 191 & 300 & 0.70 & 2 & 2 & 7200 & 20.1 & - & $1.06 \mathrm{E}-09$ & 17.7 & 7.229 \\
\hline 5 & 376 & 238 & 195 & 300 & 0.70 & 2 & 2 & 7200 & 22.1 & - & 1.04E-09 & 17.4 & 7.400 \\
\hline 6 & 624 & -475 & -595 & $\approx 10$ & 0.70 & 2 & 2 & 7200 & 22.3 & - & $4.02 \mathrm{E}-11$ & 17.2 & 7.503 \\
\hline 7 & 696 & -482 & -607 & $\approx 10$ & 0.70 & 300 & 2 & 0 & 22.1 & 6.6 & $8.56 \mathrm{E}-11$ & 17.1 & 7.534 \\
\hline 8 & 935 & -495 & -614 & $\approx 10$ & 0.70 & 2 & 2 & 3600 & 22.7 & - & $6.42 \mathrm{E}-12$ & 17.1 & 7.540 \\
\hline 9 & 1031 & -499 & -609 & $\approx 10$ & 0.70 & 300 & 2 & 0 & 22.5 & 6.8 & $3.37 \mathrm{E}-11$ & 17.1 & 7.550 \\
\hline $10 \mathrm{a}$ & 1127 & -495 & -613 & $\approx 10$ & 0.70 & 1000 & 2 & 0 & 22.2 & 6.7 & negligible & 17.1 & 7.548 \\
\hline $10 \mathrm{~b}$ & 1271 & -507 & -620 & $\approx 10$ & 0.70 & 1000 & 2 & 0 & 23.0 & 6.9 & $1.20 \mathrm{E}-11$ & 17.1 & 7.552 \\
\hline 11 & 1295 & -507 & -624 & $\approx 10$ & 0.70 & 30 & 2 & 0 & 22.9 & 6.9 & $5.17 \mathrm{E}-11$ & 17.1 & 7.561 \\
\hline 12 & 1343 & -498 & -617 & $\approx 10$ & 0.70 & 300 & 2 & 0 & 23.1 & 6.9 & $1.55 \mathrm{E}-11$ & 17.1 & 7.568 \\
\hline 14 & 1608 & 248 & 151 & 250 & 0.70 & 1000 & 2 & 0 & 24.2 & 7.3 & $5.93 \mathrm{E}-10$ & 16.7 & 7.768 \\
\hline 15 & 1655 & 244 & 155 & 250 & 0.70 & 2 & 2 & 3600 & 24.4 & - & $8.70 \mathrm{E}-10$ & 16.4 & 7.916 \\
\hline
\end{tabular}

${ }^{\mathrm{a}}$ Heat $\mathrm{C} 3$, irradiated to $0.9 \times 10^{21} \mathrm{n} / \mathrm{cm}^{2}(1.35 \mathrm{dpa})$ at $\approx 288^{\circ} \mathrm{C}$.

${ }^{\mathrm{b}} \mathrm{An}$ asterisk indicates environmental enhancement of growth rates under cyclic loading.

${ }^{c}$ Represents values in the effluent. Conductivity was $\approx 0.07$ and $0.30-0.45 \mu \mathrm{S} / \mathrm{cm}$ in the feedwater and effluent, respectively. Feedwater $\mathrm{pH}$ at room temperature was 6.5.

${ }^{d}$ Based on effective yield stress, defined as the average of irradiated and nonirradiated yield stresses.

${ }^{\mathrm{e}}$ The difference between the measured crack extension and that determined from the DC potential drop measurements was $<5 \%$.

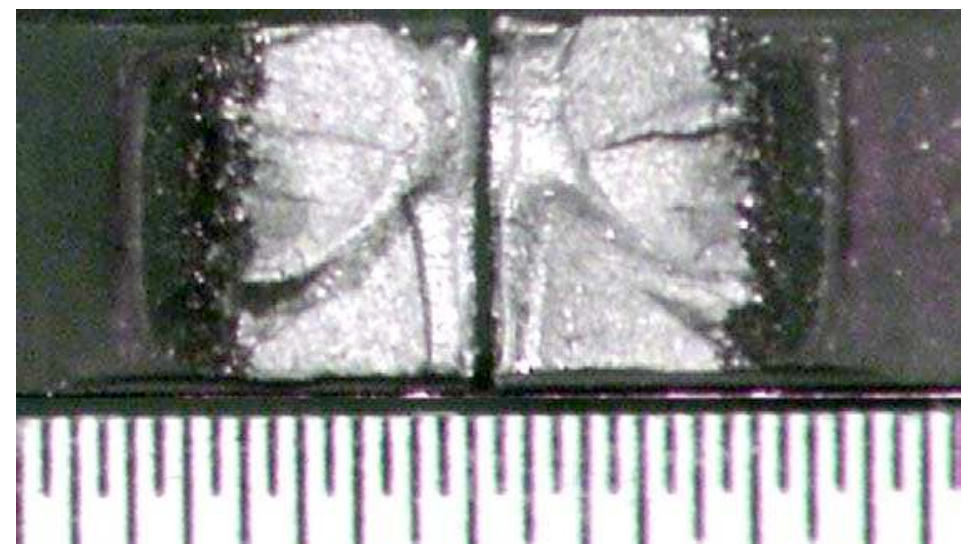

Figure A2.

Photomicrographs of the fracture surface of Specimen C3-B. 


\section{A.3 Specimen C3-C of Type $304 \mathrm{~L}$ SS Irradiated to $3.0 \mathrm{dpa}$ at $288^{\circ} \mathrm{C}$, Test CGRI-08}

Table A3. Crack growth data for Specimen C3-C of Type 304L SS in BWR water at $289^{\circ} \mathrm{C}$.

\begin{tabular}{|c|c|c|c|c|c|c|c|c|c|c|c|c|c|}
\hline $\begin{array}{c}\text { Test } \\
\text { Period }^{b} \\
\end{array}$ & $\begin{array}{c}\text { Test } \\
\text { Time, } \\
\mathrm{h} \\
\end{array}$ & $\begin{array}{c}\mathrm{EC} \\
\mathrm{mV} \\
\mathrm{Pt} \\
\end{array}$ & $\begin{array}{l}\mathrm{c} \\
\text { Ste) } \\
\text { Steel }\end{array}$ & $\begin{array}{c}\mathrm{O}_{2} \\
\text { Conc., } \\
\text { ppb }\end{array}$ & $\begin{array}{c}\mathrm{R} \\
\text { Load } \\
\text { Ratio } \\
\end{array}$ & $\begin{array}{c}\text { Rise } \\
\text { Time, } \\
\mathrm{s} \\
\end{array}$ & $\begin{array}{c}\text { Return } \\
\text { Time, } \\
\mathrm{s} \\
\end{array}$ & $\begin{array}{l}\text { Hold } \\
\text { Time, } \\
\text { s } \\
\end{array}$ & $\begin{array}{c}\mathrm{K}_{\max }, \\
\mathrm{MPa} \mathrm{m}^{1 / 2}\end{array}$ & $\begin{array}{c}\Delta \mathrm{K}, \\
\mathrm{MPa} \mathrm{m}^{1 / 2}\end{array}$ & $\begin{array}{c}\text { Growth } \\
\text { Rate, } \\
\mathrm{m} / \mathrm{s}\end{array}$ & $\begin{array}{c}\text { Allowed } \\
\mathrm{K}_{\max }{ }^{\mathrm{d}} \\
\mathrm{MPa} \mathrm{m}^{1 / 2} \\
\end{array}$ & $\begin{array}{c}\text { Crack } \\
\text { Length, } \\
\mathrm{mm}\end{array}$ \\
\hline 1 & 46 & 241 & 164 & 300 & 0.26 & 2 & 2 & 0 & 17.9 & 13.2 & $2.00 \mathrm{E}-08$ & 22.4 & $\begin{array}{l}6.000 \\
6.702\end{array}$ \\
\hline 2 & 71 & 223 & 155 & 300 & 0.53 & 30 & 2 & 0 & 18.4 & 8.7 & $2.22 \mathrm{E}-09$ & 22.1 & 6.830 \\
\hline $3^{*}$ & 99 & 235 & 167 & 300 & 0.70 & 300 & 2 & 0 & 18.8 & 5.6 & $1.73 \mathrm{E}-09$ & 21.8 & 6.977 \\
\hline $4^{*}$ & 142 & 232 & 164 & 300 & 0.69 & 1000 & 2 & 0 & 19.2 & 6.0 & $1.25 \mathrm{E}-09$ & 21.4 & 7.167 \\
\hline 5 & 191 & 233 & 164 & 300 & 0.70 & 2 & 2 & 3600 & 19.4 & - & $6.83 \mathrm{E}-10$ & 21.1 & 7.294 \\
\hline 6 & 311 & 200 & 150 & 100 & 0.70 & 2 & 2 & 3600 & 23.7 & - & $5.07 \mathrm{E}-10$ & 20.5 & 7.572 \\
\hline 7 & 560 & -547 & -294 & $\approx 10$ & 0.70 & 2 & 2 & 3600 & 27.5 & - & $6.91 \mathrm{E}-10$ & 19.1 & 8.171 \\
\hline 8 & 706 & -551 & -502 & $\approx 10$ & 0.70 & 2 & 2 & 3600 & 34.7 & - & 2.04E-09 & 16.4 & 9.154 \\
\hline 9 & 724 & -557 & -457 & $\approx 10$ & 0.70 & 2 & 2 & 3600 & 37.0 & - & $3.70 \mathrm{E}-09$ & 15.8 & 9.367 \\
\hline
\end{tabular}

${ }^{\text {a } H e a t ~ C 3, ~ i r r a d i a t e d ~ t o ~} 2.0 \times 10^{21} \mathrm{n} / \mathrm{cm}^{2}(3.0 \mathrm{dpa})$ at $\approx 288^{\circ} \mathrm{C}$.

${ }^{\mathrm{b}} \mathrm{An}$ asterisk indicates environmental enhancement of growth rates under cyclic loading.

${ }^{\mathrm{c}}$ Represents values in the effluent. Conductivity was $\approx 0.07$ and $0.30-0.45 \mu \mathrm{S} / \mathrm{cm}$ in the feedwater and effluent, respectively. Feedwater $\mathrm{pH}$ at room temperature was 6.5.

${ }^{d}$ Based on effective yield stress, defined as the average of irradiated and nonirradiated yield stresses.

eActual crack extension was $40 \%$ greater than the value determined from the DC potential drop measurements.

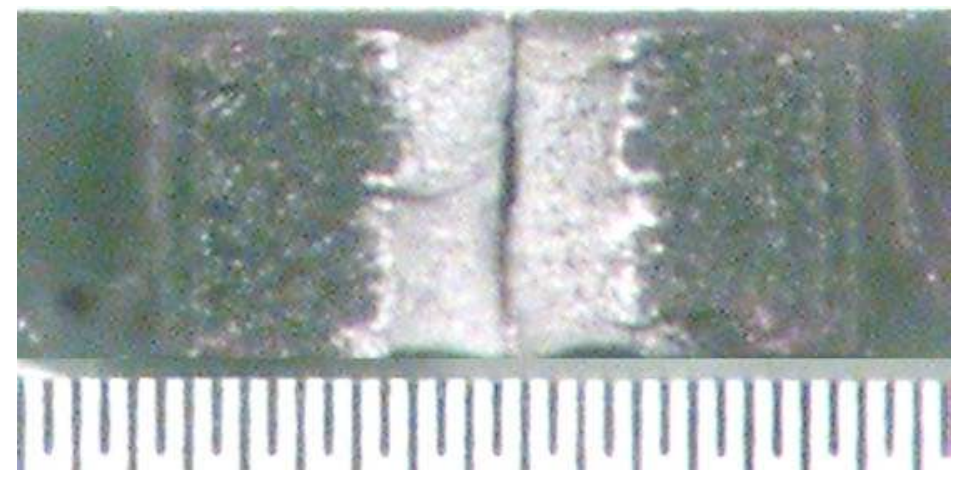

Figure A3.

Photograph of the fracture surfaces of the two halves of the fractured Specimen C3-C. 


\section{A.4 Specimen C16-B of Type $316 \mathrm{~L}$ SS Irradiated to 3.00 dpa at $288^{\circ} \mathrm{C}$, Test CGRI-09}

Table A4. Crack growth data for Specimen C16-Ba of Type $316 \mathrm{~L}$ SS in BWR water at $289^{\circ} \mathrm{C}$.

\begin{tabular}{|c|c|c|c|c|c|c|c|c|c|c|c|c|c|}
\hline $\begin{array}{c}\text { Test } \\
\text { Period }^{b} \\
\end{array}$ & $\begin{array}{c}\text { Test } \\
\text { Time, } \\
\mathrm{h}\end{array}$ & $\begin{array}{c}\mathrm{EC} \\
\mathrm{mV} \\
\mathrm{Pt} \\
\end{array}$ & $\begin{array}{l}\mathrm{P}, \mathrm{c} \\
\text { SHE) } \\
\text { Steel } \\
\end{array}$ & $\begin{array}{c}\mathrm{O}_{2} \\
\text { Conc., } \\
\text { ppb }\end{array}$ & $\begin{array}{c}\mathrm{R} \\
\text { Load } \\
\text { Ratio } \\
\end{array}$ & $\begin{array}{c}\text { Rise } \\
\text { Time, } \\
\mathrm{s} \\
\end{array}$ & $\begin{array}{c}\text { Return } \\
\text { Time, } \\
\text { s } \\
\end{array}$ & $\begin{array}{l}\text { Hold } \\
\text { Time, } \\
\text { s } \\
\end{array}$ & $\begin{array}{c}\mathrm{K}_{\max }, \\
\mathrm{MPa} \mathrm{m}^{1 / 2}\end{array}$ & $\begin{array}{c}\Delta \mathrm{K}, \\
\mathrm{MPa} \mathrm{m}^{1 / 2}\end{array}$ & $\begin{array}{c}\text { Growth } \\
\text { Rate, } \\
\mathrm{m} / \mathrm{s}\end{array}$ & $\begin{array}{c}\text { Allowed } \\
\mathrm{K}_{\max },{ }^{d} \\
\mathrm{MPa} \mathrm{m}^{1 / 2}\end{array}$ & $\begin{array}{c}\text { Crack } \\
\text { Length, } \\
\text { mm }\end{array}$ \\
\hline & & & & & & & & & & & & & 6.000 \\
\hline Pre a & 6 & - & - & 250 & 0.32 & 1 & 1 & 0 & 14.3 & 9.8 & $1.75 \mathrm{E}-08$ & 22.9 & 6.132 \\
\hline Pre $b$ & 30 & 232 & 144 & 250 & 0.30 & 2 & 2 & 0 & 14.0 & 9.8 & 7.54E-09 & 22.5 & 6.328 \\
\hline Pre c & 52 & 227 & 144 & 250 & 0.31 & 2 & 2 & 0 & 14.2 & 9.8 & 8.94E-09 & 22.3 & 6.417 \\
\hline 1 & 94 & 224 & 148 & 250 & 0.56 & 12 & 2 & 0 & 14.6 & 6.4 & $4.94 \mathrm{E}-10$ & 22.2 & 6.450 \\
\hline 2 & 132 & 226 & 147 & 250 & 0.73 & 30 & 2 & 0 & 14.8 & 4.0 & $8.65 \mathrm{E}-10$ & 22.0 & 6.546 \\
\hline $3^{*}$ & 173 & 228 & 151 & 250 & 0.71 & 300 & 2 & 0 & 15.0 & 4.4 & $8.16 \mathrm{E}-10$ & 21.8 & 6.666 \\
\hline $4^{*}$ & 198 & 224 & 153 & 250 & 0.70 & 1,000 & 12 & 0 & 15.0 & 4.5 & $7.33 \mathrm{E}-10$ & 21.7 & 6.728 \\
\hline 5 & 265 & 162 & 117 & 250 & 0.70 & 12 & 12 & 3600 & 15.2 & - & $4.62 \mathrm{E}-10$ & 21.4 & 6.877 \\
\hline 6 & 410 & -547 & -298 & $<30$ & 0.70 & 12 & 12 & 3600 & 15.3 & - & $1.90 \mathrm{E}-11$ & 21.3 & 6.908 \\
\hline 7 & 504 & -562 & -410 & $<30$ & 0.70 & 1,000 & 12 & 0 & 15.1 & 4.5 & $2.76 \mathrm{E}-11$ & 21.3 & 6.914 \\
\hline 8 & 527 & -560 & -449 & $<30$ & 0.73 & 30 & 2 & 0 & 15.2 & 4.1 & $6.07 \mathrm{E}-11$ & 21.3 & 6.920 \\
\hline 9 & 552 & -557 & -502 & $<30$ & 0.70 & 30 & 2 & 0 & 17.3 & 5.2 & $2.51 \mathrm{E}-10$ & 21.2 & 6.971 \\
\hline 10 & 600 & -554 & -545 & $<30$ & 0.69 & 1,000 & 12 & 0 & 17.2 & 5.3 & $3.59 \mathrm{E}-11$ & 21.2 & 6.977 \\
\hline 11 & 672 & -557 & -554 & $<30$ & 0.70 & 12 & 12 & 3600 & 17.3 & - & $1.73 \mathrm{E}-11$ & 21.1 & 6.983 \\
\hline 12 & 792 & -438 & -597 & $<30$ & 0.70 & 12 & 12 & 3600 & 19.7 & - & $4.11 \mathrm{E}-11$ & 21.1 & 7.011 \\
\hline 13 & 866 & 219 & 139 & 250 & 0.70 & 12 & 12 & 3600 & 19.6 & - & $7.14 \mathrm{E}-10$ & 21.0 & 7.071 \\
\hline 14 & 871 & 224 & 148 & 250 & 0.70 & 12 & 12 & 3600 & 21.9 & - & $1.10 \mathrm{E}-09$ & 20.9 & 7.088 \\
\hline 15 & 888 & 224 & 148 & 250 & $1.00^{\mathrm{f}}$ & - & - & - & 21.9 & - & $5.27 \mathrm{E}-10$ & 20.9 & 7.118 \\
\hline
\end{tabular}

${ }^{\mathrm{a}}$ Heat $\mathrm{C} 16$, irradiated to $2.0 \times 10^{21} \mathrm{n} / \mathrm{cm}^{2}(3.0 \mathrm{dpa})$ at $\approx 288^{\circ} \mathrm{C}$.

${ }^{\mathrm{b}}$ An asterisk indicates environmental enhancement of growth rates under cyclic loading.

${ }^{\mathrm{c}}$ Represents values in the effluent. Effluent conductivity was $\approx 0.45 \mu \mathrm{S} / \mathrm{cm}$ and DO was $\approx 250 \mathrm{ppb}$ during high-DO test and $<30 \mathrm{ppb}$ during low-DO test. Feedwater conductivity was $0.07 \mu \mathrm{S} / \mathrm{cm}$ and $\mathrm{pH}$ at room temperature was 6.5.

${ }^{\mathrm{d}}$ Based on effective yield stress, defined as the average of irradiated and nonirradiated yield stresses.

${ }^{\mathrm{e}}$ The difference between the measured crack extension and that determined from the DC potential drop measurements was $<5 \%$.

${ }^{\mathrm{f}}$ Constant-displacement test.

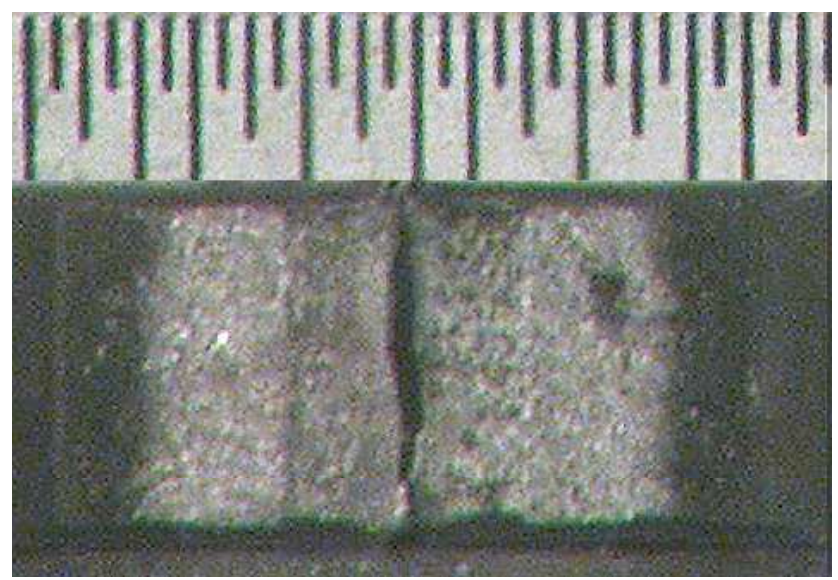

Figure A4.

Photograph of the fracture surfaces of the two halves of the fractured Specimen C16-B. 
A.5 Specimen GG5B-A of Type 304L SA weld HAZ as-welded, Test CGR-10.

Table A5. Crack growth results for Specimen GG5B-A of Type 304L HAZ in high-purity water at $289^{\circ} \mathrm{C}$.

\begin{tabular}{|c|c|c|c|c|c|c|c|c|c|c|c|c|c|}
\hline $\begin{array}{c}\text { Test } \\
\text { Period }^{b} \\
\end{array}$ & $\begin{array}{c}\text { Test } \\
\text { Time, } \\
\mathrm{h}\end{array}$ & $\begin{array}{r}\mathrm{E} \\
\mathrm{mV} \\
\mathrm{Pt} \\
\end{array}$ & $\begin{array}{l}\mathrm{P}, \mathrm{c} \\
\text { SHE) } \\
\text { Steel } \\
\end{array}$ & $\begin{array}{c}\mathrm{O}_{2} \\
\text { Conc., } \\
\text { ppb }\end{array}$ & $\begin{array}{c}\text { R } \\
\text { Load } \\
\text { Ratio } \\
\end{array}$ & $\begin{array}{c}\text { Rise } \\
\text { Time, } \\
\mathrm{s} \\
\end{array}$ & $\begin{array}{c}\text { Return } \\
\text { Time, } \\
\mathrm{s} \\
\end{array}$ & $\begin{array}{c}\text { Hold } \\
\text { Time, } \\
\mathrm{s} \\
\end{array}$ & $\begin{array}{c}\mathrm{K}_{\max }, \\
\mathrm{MPa} \mathrm{m}^{1 / 2}\end{array}$ & $\begin{array}{c}\Delta \mathrm{K}, \\
\mathrm{MPa} \mathrm{m}^{1 / 2}\end{array}$ & $\begin{array}{c}\text { Growth } \\
\text { Rate, } \\
\mathrm{m} / \mathrm{s}\end{array}$ & $\begin{array}{c}\text { Allowed } \\
\mathrm{K}_{\max }{ }^{\mathrm{d}} \\
\mathrm{MPa} \mathrm{m}^{1 / 2}\end{array}$ & $\begin{array}{c}\text { Crack } \\
\text { Length, } \\
\text { mm }\end{array}$ \\
\hline & & & & & & & & & & & & & 5.797 \\
\hline Pre a & 97 & $\mathrm{f}$ & $\mathrm{f}$ & 580 & 0.23 & 0.25 & 0.25 & 0 & 16.7 & 12.9 & 7.57E-08 & 19.3 & 6.411 \\
\hline Pre $b$ & 98 & $\mathrm{f}$ & $\mathrm{f}$ & 580 & 0.23 & 0.25 & 0.25 & 0 & 15.0 & 11.5 & $3.42 \mathrm{E}-08$ & 19.1 & 6.498 \\
\hline Pre c & 114 & $\mathrm{f}$ & $\mathrm{f}$ & 590 & 0.23 & 7.5 & 7.5 & 0 & 14.2 & 11.0 & $3.59 \mathrm{E}-10$ & 19.1 & 6.518 \\
\hline Pre d & 120 & f & $\mathrm{f}$ & 590 & 0.23 & 0.50 & 0.50 & 0 & 15.7 & 12.1 & $3.40 \mathrm{E}-08$ & 18.7 & 6.746 \\
\hline 1 & 143 & $\mathrm{f}$ & $\mathrm{f}$ & 485 & 0.52 & 30 & 2 & 0 & 15.5 & 7.4 & $5.85 \mathrm{E}-11$ & 18.6 & 6.764 \\
\hline $2 \mathrm{a}$ & 259 & $\mathrm{f}$ & $\mathrm{f}$ & 440 & 0.71 & 30 & 2 & 0 & 17.0 & 4.9 & negligible & 18.6 & 6.771 \\
\hline $2 b$ & 306 & $\mathrm{f}$ & $\mathrm{f}$ & 450 & 0.71 & 30 & 2 & 0 & 17.0 & 4.9 & $1.52 \mathrm{E}-11$ & 18.6 & 6.772 \\
\hline $2 c^{*}$ & 337 & $\mathrm{f}$ & $\mathrm{f}$ & 465 & 0.72 & 30 & 2 & 0 & 20.6 & 5.8 & $3.15 \mathrm{E}-10$ & 18.6 & 6.795 \\
\hline $3^{*}$ & 407 & $\mathrm{f}$ & $\mathrm{f}$ & 460 & 0.71 & 300 & 2 & 0 & 20.8 & 6.0 & $1.81 \mathrm{E}-10$ & 18.5 & 6.842 \\
\hline $4^{*}$ & 455 & f & f & 500 & 0.71 & 1,000 & 2 & 0 & 20.9 & 6.1 & $1.26 \mathrm{E}-10$ & 18.5 & 6.866 \\
\hline 5 & 572 & $\mathrm{f}$ & $\mathrm{f}$ & 500 & 0.71 & 12 & 12 & 3600 & 21.1 & 6.1 & $6.01 \mathrm{E}-11$ & 18.4 & 6.893 \\
\hline 6 & 646 & $\mathrm{f}$ & $\mathrm{f}$ & 500 & 0.71 & 12 & 12 & 3600 & 26.5 & 7.7 & $1.72 \mathrm{E}-10$ & 18.3 & 6.957 \\
\hline 7 & 692 & $\mathrm{f}$ & $\mathrm{f}$ & 500 & 0.71 & 12 & 12 & 3600 & 26.9 & 7.8 & $1.55 \mathrm{E}-10$ & 18.2 & 6.985 \\
\hline 8 & 767 & $\mathrm{f}$ & $\mathrm{f}$ & 500 & 0.71 & 1000 & 2 & 0 & 27.4 & 7.9 & $3.18 \mathrm{E}-10$ & 18.1 & 7.067 \\
\hline
\end{tabular}

${ }^{\mathrm{a} N o n i r r a d i a t e d ~ G r a n d ~ G u l f ~ H 5 ~ S A ~ w e l d ~ b o t t o m ~ s h e l l ~ H A Z, ~ a s-w e l d e d ~ c o n d i t i o n . ~}$

${ }^{\mathrm{b}}$ An asterisk indicates environmental enhancement of growth rates under cyclic loading.

${ }^{\mathrm{c}}$ Represents values in the effluent.

dBased on ASTM 647 criterion and flow stress.

${ }^{\mathrm{e}}$ The difference between the measured crack extension and that determined from the DC potential drop measurements was $<5 \%$.

${ }^{\mathrm{f}}$ Could not be measured because of a faulty reference electrode.

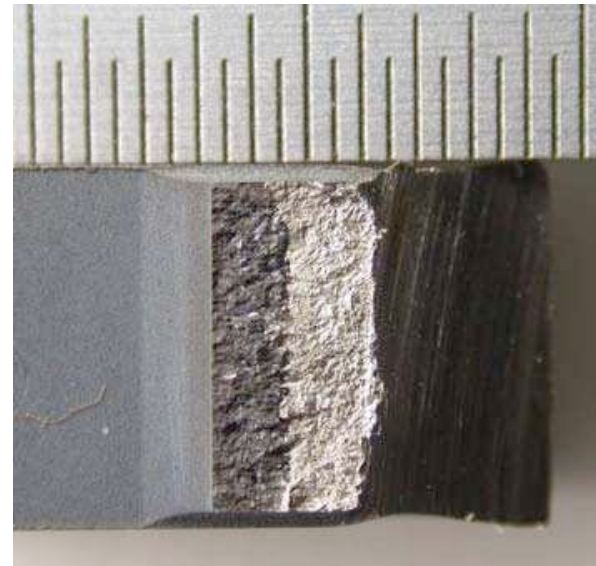

(a)

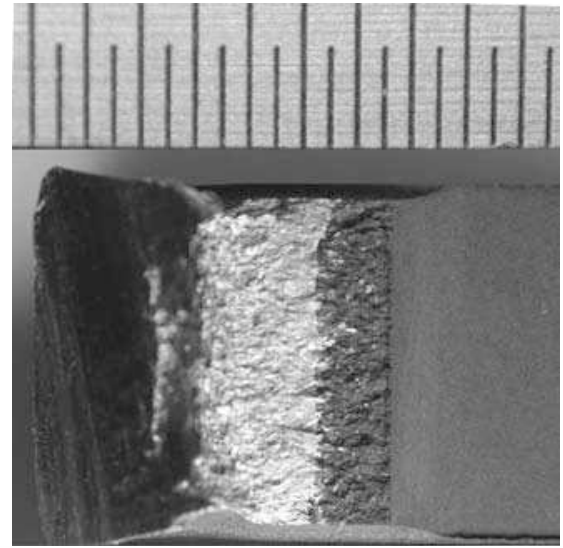

(b)

Figure A5. Photomicrograph of the fracture surface of Specimen GG5B-A. 
A.6 Specimen 85-3A-TT of Type 304 SMA weld HAZ thermally treated, Test CGR-11.

Table A6. Crack growth results for Specimen 85-3A-TTa of nonirradiated Type 304 SS SMA weld HAZ in high-purity water at $289^{\circ} \mathrm{C}$.

\begin{tabular}{|c|c|c|c|c|c|c|c|c|c|c|c|c|c|}
\hline $\begin{array}{c}\text { Test } \\
\text { Period }^{\mathrm{b}} \\
\end{array}$ & $\begin{array}{c}\text { Test } \\
\text { Time, } \\
\mathrm{h}\end{array}$ & $\begin{array}{c}\mathrm{EC} \\
\mathrm{mV} \\
\mathrm{Pt} \\
\end{array}$ & $\begin{array}{l}\mathrm{P}, \mathrm{c} \\
\text { Steel } \\
\text { Steel }\end{array}$ & $\begin{array}{c}\mathrm{O}_{2} \\
\text { Conc., } \\
\text { ppb }\end{array}$ & $\begin{array}{c}\mathrm{R} \\
\text { Load } \\
\text { Ratio } \\
\end{array}$ & $\begin{array}{c}\text { Rise } \\
\text { Time, } \\
\text { s } \\
\end{array}$ & $\begin{array}{c}\text { Return } \\
\text { Time, } \\
\text { s } \\
\end{array}$ & $\begin{array}{c}\text { Hold } \\
\text { Time, } \\
\mathrm{s} \\
\end{array}$ & $\begin{array}{c}\mathrm{K}_{\max }, \\
\mathrm{MPa} \mathrm{m}^{1 / 2}\end{array}$ & $\begin{array}{c}\Delta \mathrm{K}, \\
\mathrm{MPa} \mathrm{m}{ }^{1 / 2}\end{array}$ & $\begin{array}{c}\text { Growth } \\
\text { Rate, } \\
\text { m/s }\end{array}$ & $\begin{array}{c}\text { Allowed } \\
\mathrm{K}_{\max },{ }^{d} \\
\mathrm{MPa} \mathrm{m}^{1 / 2}\end{array}$ & $\begin{array}{c}\text { Crack } \\
\text { Length, } \\
\text { mm }\end{array}$ \\
\hline & & & & & & & & & & & & & 5.786 \\
\hline Pre a & 144 & - & - & 690 & 0.21 & 0.50 & 0.50 & 0 & 16.1 & 12.7 & $5.46 \mathrm{E}-08$ & 22.0 & 6.237 \\
\hline Pre $b$ & 148 & 183 & 27 & 650 & 0.21 & 0.50 & 0.50 & 0 & 15.0 & 11.9 & $5.00 \mathrm{E}-08$ & 21.6 & 6.480 \\
\hline 1 & 166 & 182 & 32 & 600 & 0.51 & 30 & 2 & 0 & 14.6 & 7.2 & $5.61 \mathrm{E}-11$ & 21.5 & 6.507 \\
\hline 2 & 190 & 184 & 41 & 600 & 0.51 & 30 & 2 & 0 & 16.7 & 8.2 & $5.50 \mathrm{E}-10$ & 21.4 & 6.550 \\
\hline 3 & 215 & 182 & 45 & 600 & 0.71 & 30 & 2 & 0 & 16.9 & 4.9 & $3.16 \mathrm{E}-11$ & 21.4 & 6.555 \\
\hline $4^{*}$ & 264 & 184 & 60 & 600 & 0.71 & 30 & 2 & 0 & 19.8 & 5.8 & $8.85 \mathrm{E}-10$ & 21.1 & 6.709 \\
\hline $5 a^{*}$ & 298 & 188 & 68 & 600 & 0.71 & 300 & 2 & 0 & 19.8 & 5.7 & $2.75 \mathrm{E}-10$ & 21.0 & 6.744 \\
\hline $5 b^{*}$ & 338 & 187 & 79 & 600 & 0.71 & 300 & 2 & 0 & 20.2 & 5.9 & $7.91 \mathrm{E}-10$ & 20.8 & 6.862 \\
\hline $6^{*}$ & 384 & 188 & 87 & 600 & 0.70 & 1,000 & 2 & 0 & 20.5 & 6.2 & $4.57 \mathrm{E}-10$ & 20.6 & 6.937 \\
\hline 7 & 478 & 192 & 106 & 600 & 0.70 & 12 & 12 & 3600 & 21.2 & - & $6.60 \mathrm{E}-10$ & 20.2 & 7.150 \\
\hline 8 & 646 & -482 & -633 & 45 & 0.70 & 12 & 12 & 3600 & 21.4 & - & $9.13 \mathrm{E}-11$ & 20.0 & 7.227 \\
\hline 9 & 862 & -483 & -627 & $<40$ & 0.70 & 12 & 12 & 3600 & 25.0 & - & $4.29 \mathrm{E}-11$ & 19.9 & 7.293 \\
\hline
\end{tabular}

${ }^{\mathrm{a} N}$ Nonirradiated Type $304 \mathrm{SS}$ (Heat 10285) SMA weld HAZ, as-welded plus thermally treated for $24 \mathrm{~h}$ at $500^{\circ} \mathrm{C}$.

$\mathrm{b}_{\text {An }}$ asterisk indicates environmental enhancement of growth rates under cyclic loading.

${ }^{\mathrm{c}}$ Represents values in the effluent. Water flow rate was maintained at $\approx 105 \mathrm{~mL} / \mathrm{min}$.

${ }^{\mathrm{d}}$ Based on ASTM 647 criterion and flow stress.

eActual crack extension was $40 \%$ greater than the value determined from the DC potential drop measurements.

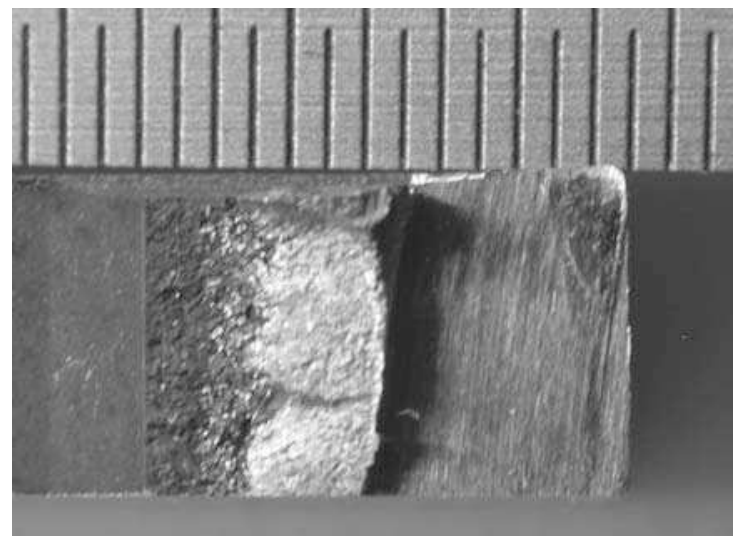

(a)

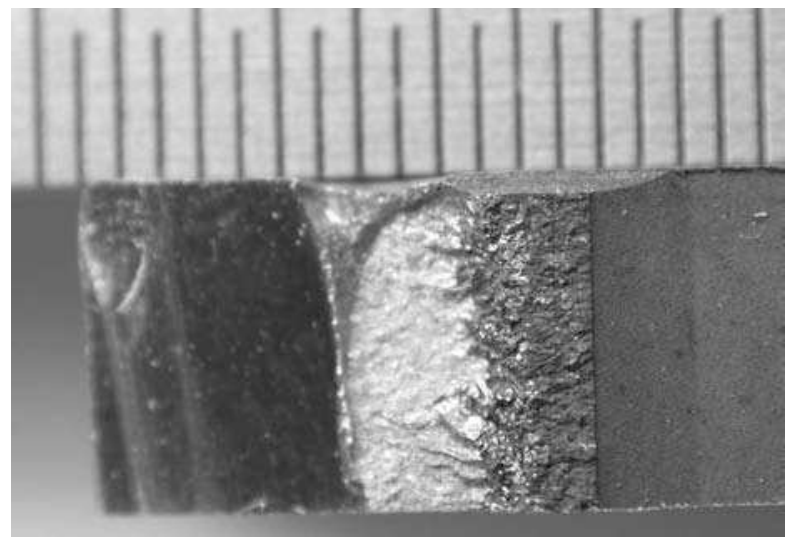

(b)

Figure A6. Photomicrographs of the fracture surfaces of the two halves of Specimen 85-3A-TT. 
A.7 Specimen GG3B-A-TT of Type 304L SA weld HAZ thermally treated, Test CGR-14.

Table A7. Crack growth results for Specimen GG3B-A-TTa of Type 304L HAZ in high-purity water at $289^{\circ} \mathrm{C}$.

\begin{tabular}{|c|c|c|c|c|c|c|c|c|c|c|c|c|c|}
\hline $\begin{array}{c}\text { Test } \\
\text { Period }^{b} \\
\end{array}$ & $\begin{array}{c}\text { Test } \\
\text { Time, } \\
\mathrm{h}\end{array}$ & $\begin{array}{r}\mathrm{E} \\
\mathrm{mV} \\
\mathrm{Pt} \\
\end{array}$ & $\begin{array}{l}\mathrm{P}, \mathrm{c} \\
\text { SHE) } \\
\text { Steel } \\
\end{array}$ & $\begin{array}{c}\mathrm{O}_{2} \\
\text { Conc., } \\
\text { ppb }\end{array}$ & $\begin{array}{c}\mathrm{R} \\
\text { Load } \\
\text { Ratio } \\
\end{array}$ & $\begin{array}{c}\text { Rise } \\
\text { Time, } \\
\mathrm{s} \\
\end{array}$ & $\begin{array}{c}\text { Return } \\
\text { Time, } \\
\mathrm{s} \\
\end{array}$ & $\begin{array}{c}\text { Hold } \\
\text { Time, } \\
\text { s } \\
\end{array}$ & $\begin{array}{c}\mathrm{K}_{\max }, \\
\mathrm{MPa} \mathrm{m}^{1 / 2}\end{array}$ & $\begin{array}{c}\Delta \mathrm{K}, \\
\mathrm{MPa} \mathrm{m}^{1 / 2}\end{array}$ & $\begin{array}{c}\text { Growth } \\
\text { Rate, } \\
\mathrm{m} / \mathrm{s}\end{array}$ & $\begin{array}{c}\text { Allowed } \\
\mathrm{K}_{\max }{ }^{\mathrm{d}} \\
\mathrm{MPa} \mathrm{m}^{1 / 2}\end{array}$ & $\begin{array}{c}\text { Crack } \\
\text { Length, } \\
\text { mm }\end{array}$ \\
\hline & & & & & & & & & & & & & 5.788 \\
\hline Pre a & 120 & 181 & 20 & 450 & 0.31 & 0.5 & 0.5 & 0 & 14.3 & 9.9 & 7.71E-09 & 20.2 & 5.856 \\
\hline Pre b & 143 & 185 & 25 & 450 & 0.31 & 5 & 5 & 0 & 14.4 & 10.0 & $5.91 \mathrm{E}-09$ & 20.0 & 5.991 \\
\hline Pre c & 238 & 192 & 36 & 450 & 0.51 & 1 & 1 & 0 & 15.0 & 7.4 & $1.34 \mathrm{E}-09$ & 19.5 & 6.255 \\
\hline $1 a^{*}$ & 275 & 192 & 40 & 470 & 0.71 & 12 & 2 & 0 & 16.0 & 4.6 & $8.66 \mathrm{E}-10$ & 19.4 & 6.307 \\
\hline $1 b^{*}$ & 305 & 193 & 42 & 470 & 0.71 & 12 & 2 & 0 & 16.3 & 4.7 & $2.50 \mathrm{E}-09$ & 19.2 & 6.475 \\
\hline $2 *$ & 328 & 194 & 44 & 470 & 0.71 & 30 & 2 & 0 & 16.5 & 4.8 & $1.22 \mathrm{E}-09$ & 19.0 & 6.579 \\
\hline $3^{*}$ & 403 & 195 & 53 & 450 & 0.70 & 300 & 2 & 0 & 16.7 & 5.0 & $2.80 \mathrm{E}-10$ & 18.8 & 6.659 \\
\hline $4^{*}$ & 522 & 198 & 65 & 400 & 0.70 & 1,000 & 12 & 0 & 16.7 & 5.0 & $1.12 \mathrm{E}-10$ & 18.8 & 6.706 \\
\hline $5 a$ & 580 & 203 & 79 & 400 & 0.70 & 12 & 12 & 3600 & 16.4 & 4.9 & $4.34 \mathrm{E}-11$ & 18.7 & 6.717 \\
\hline $5 b$ & 765 & 202 & 87 & 400 & 0.70 & 12 & 12 & 3600 & 16.7 & 5.0 & $9.60 \mathrm{E}-12$ & 18.4 & 6.882 \\
\hline 6 & 1000 & 202 & 88 & 400 & 0.70 & 500 & 12 & 3600 & 18.5 & 5.6 & $9.06 \mathrm{E}-12$ & 18.4 & 6.890 \\
\hline 7 & 1094 & 204 & 90 & 400 & 0.70 & 500 & 12 & 3600 & 20.4 & 6.1 & $4.47 \mathrm{E}-12$ & 18.4 & 6.894 \\
\hline
\end{tabular}

${ }^{\mathrm{a} N o n i r r a d i a t e d ~ G r a n d ~ G u l f ~ H 5 ~ S A ~ w e l d ~ b o t t o m ~ s h e l l ~ H A Z, ~ a s-w e l d e d ~ p l u s ~ t h e r m a l l y ~ t r e a t e d ~ f o r ~} 24 \mathrm{~h}$ at $500^{\circ} \mathrm{C}$.

${ }^{\mathrm{b}}$ An asterisk indicates environmental enhancement of growth rates under cyclic loading.

${ }^{\mathrm{c}}$ Represents values in the effluent. Water flow rate was $\approx 100 \mathrm{~mL} / \mathrm{min}$.

${ }^{\mathrm{d}}$ Based on ASTM 647 criterion and flow stress.

eActual crack extension was $30 \%$ greater than the value determined from the DC potential drop measurements.

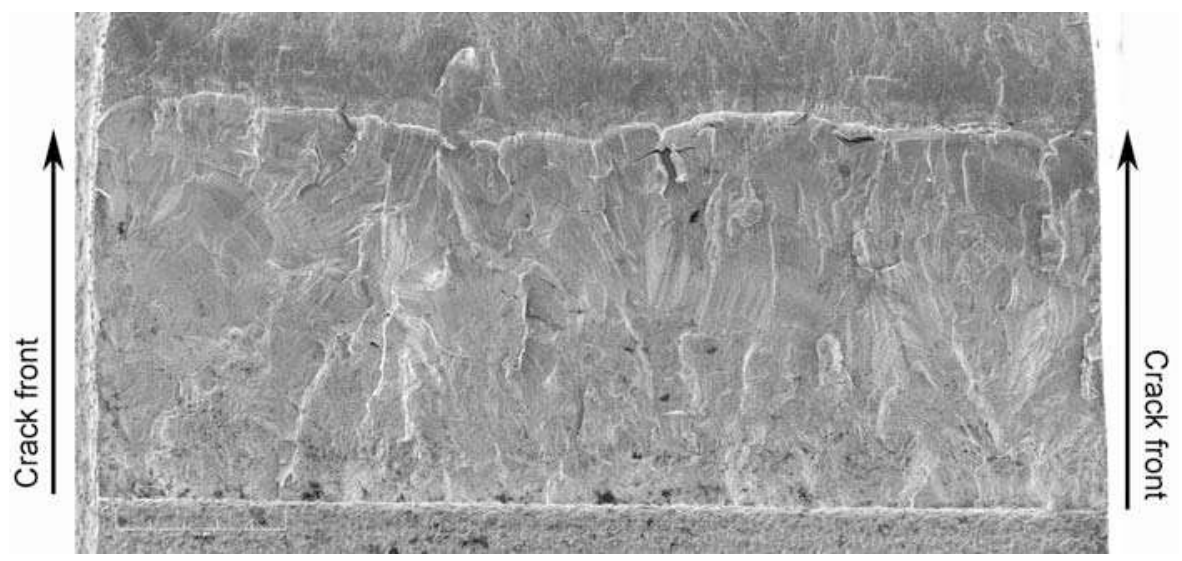

Figure A7. Micrograph of the fracture surface of Specimen GG3B-A-TT tested in high-DO water at $289^{\circ} \mathrm{C}$. 


\section{A.8 Specimen 85-YA of Type 304 SMA weld HAZ as-welded, Test CGR-22.}

Table A8. Crack growth results for Specimen 85-YAa of nonirradiated Type 304 SS SMA weld HAZ in high-purity water at $289^{\circ} \mathrm{C}$.

\begin{tabular}{|c|c|c|c|c|c|c|c|c|c|c|c|c|c|}
\hline $\begin{array}{c}\text { Test } \\
\text { Period }^{b}\end{array}$ & $\begin{array}{c}\text { Test } \\
\text { Time, } \\
\mathrm{h}\end{array}$ & $\begin{array}{r}\mathrm{E} \\
\mathrm{mV} \\
\mathrm{Pt}\end{array}$ & $\begin{array}{l}\mathrm{P}, \mathrm{c} \\
\mathrm{SHE}) \\
\text { Steel }\end{array}$ & $\begin{array}{c}\mathrm{O}_{2} \\
\text { Conc., } \\
\text { ppb }\end{array}$ & $\begin{array}{c}\mathrm{R} \\
\text { Load } \\
\text { Ratio } \\
\end{array}$ & $\begin{array}{c}\text { Rise } \\
\text { Time, } \\
\mathrm{s}\end{array}$ & $\begin{array}{c}\text { Return } \\
\text { Time, } \\
\mathrm{s}\end{array}$ & $\begin{array}{l}\text { Hold } \\
\text { Time, } \\
\text { s }\end{array}$ & $\begin{array}{c}\mathrm{K}_{\max }, \\
\mathrm{MPa} \mathrm{m}^{1 / 2}\end{array}$ & $\begin{array}{c}\Delta \mathrm{K}, \\
\mathrm{MPa} \mathrm{m}^{1 / 2}\end{array}$ & $\begin{array}{c}\text { Growth } \\
\text { Rate, } \\
\mathrm{m} / \mathrm{s}\end{array}$ & $\begin{array}{c}\text { Allowed } \\
\mathrm{K}_{\max },{ }^{d} \\
\mathrm{MPa} \mathrm{m}^{1 / 2}\end{array}$ & $\begin{array}{c}\text { Crack } \\
\text { Length, } \\
\mathrm{mm}\end{array}$ \\
\hline & & & & & & & & & & & & & 5.799 \\
\hline Pre a & 149 & $\mathrm{f}$ & $\mathrm{f}$ & 300 & 0.33 & 0.50 & 0.5 & 0 & 16.2 & 10.8 & $4.73 \mathrm{E}-08$ & 22.1 & 6.181 \\
\hline Pre b & 192 & $\mathrm{f}$ & $\mathrm{f}$ & 300 & 0.33 & 10 & 10 & 0 & 16.7 & 11.2 & $5.72 \mathrm{E}-09$ & 21.6 & 6.477 \\
\hline 1 & 263 & $\mathrm{f}$ & $\mathrm{f}$ & 300 & 0.52 & 300 & 12 & 0 & 16.7 & 8.0 & $2.19 \mathrm{E}-11$ & 21.6 & 6.482 \\
\hline 2 & 288 & $\mathrm{f}$ & $\mathrm{f}$ & 300 & 0.52 & 30 & 12 & 0 & 16.7 & 8.0 & $2.51 \mathrm{E}-10$ & 21.5 & 6.500 \\
\hline 3 & 318 & $\mathrm{f}$ & f & 300 & 0.52 & 30 & 12 & 0 & 19.2 & 9.2 & $6.21 \mathrm{E}-10$ & 21.3 & 6.607 \\
\hline $4^{*}$ & 384 & f & f & 300 & 0.51 & 300 & 12 & 0 & 19.3 & 9.5 & $3.68 \mathrm{E}-10$ & 21.1 & 6.693 \\
\hline $5^{*}$ & 551 & $\mathrm{f}$ & $\mathrm{f}$ & 300 & 0.51 & 1,000 & 12 & 0 & 19.8 & 9.7 & $1.85 \mathrm{E}-10$ & 20.9 & 6.795 \\
\hline 6 & 768 & $\mathrm{f}$ & $\mathrm{f}$ & 300 & 1.00 & - & - & - & 19.7 & - & negligible & 20.9 & 6.788 \\
\hline
\end{tabular}

${ }^{a}$ Nonirradiated laboratory-prepared Type 304 SS (Heat 10285) SMA weld HAZ, as-welded condition.

${ }^{\mathrm{b}} \mathrm{An}$ asterisk indicates environmental enhancement of growth rates under cyclic loading.

${ }^{\mathrm{c}}$ Represents values in the effluent. Conductivity was $\approx 0.07$ and $0.2 \mu \mathrm{S} / \mathrm{cm}$ in feedwater and effluent, respectively.

d Based on ASTM 647 criterion and flow stress.

${ }^{\mathrm{e}}$ Actual crack extension was $80 \%$ greater than the value determined from the DC potential drop measurements.

${ }^{\mathrm{f}}$ Could not be measured because of faulty temperature controller

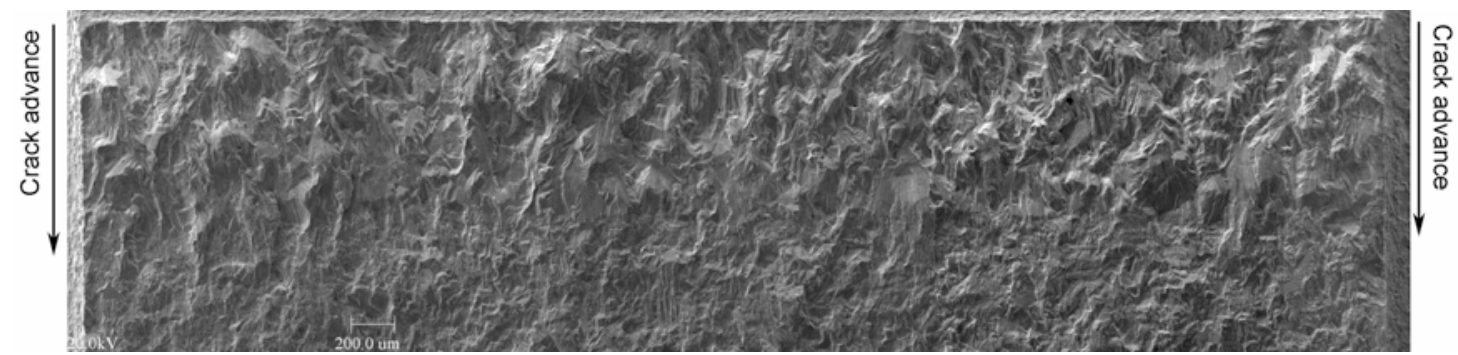

Figure A8. Micrograph of the fracture surface of Specimen $85-Y A$ tested in BWR environment at $289^{\circ} \mathrm{C}$. 


\section{A.9 Specimen GG5T-A of Type 304L SA weld HAZ as-welded and irradiated to 0.75 dpa, Test CGRI-15.}

Table A9. Crack growth results for Specimen GG5T-A of Type 304L HAZ in high-purity water at $289^{\circ} \mathrm{C}$.

\begin{tabular}{|c|c|c|c|c|c|c|c|c|c|c|c|c|c|}
\hline $\begin{array}{c}\text { Test } \\
\text { Period }^{b}\end{array}$ & $\begin{array}{c}\text { Test } \\
\text { Time, } \\
\mathrm{h}\end{array}$ & $\begin{array}{c}\mathrm{E} \\
\mathrm{mV} \\
\mathrm{Pt}\end{array}$ & $\begin{array}{l}\mathrm{P}, \mathrm{c} \\
\text { SHE) } \\
\text { Steel }\end{array}$ & $\begin{array}{c}\mathrm{O}_{2} \\
\text { Conc., } \\
\text { ppb }\end{array}$ & $\begin{array}{c}\text { R } \\
\text { Load } \\
\text { Ratio } \\
\end{array}$ & $\begin{array}{c}\text { Rise } \\
\text { Time, } \\
\mathrm{s}\end{array}$ & $\begin{array}{c}\text { Return } \\
\text { Time, } \\
\text { s }\end{array}$ & $\begin{array}{c}\text { Hold } \\
\text { Time, } \\
\text { s }\end{array}$ & $\begin{array}{c}\mathrm{K}_{\max }, \\
\mathrm{MPa} \mathrm{m}^{1 / 2}\end{array}$ & $\begin{array}{c}\Delta \mathrm{K}, \\
\mathrm{MPa} \mathrm{m}^{1 / 2}\end{array}$ & $\begin{array}{c}\text { Growth } \\
\text { Rate, } \\
\mathrm{m} / \mathrm{s}\end{array}$ & $\begin{array}{c}\text { Allowed } \\
\mathrm{K}_{\max }{ }^{\mathrm{d}} \\
\mathrm{MPa} \mathrm{m}^{1 / 2}\end{array}$ & $\begin{array}{c}\text { Crack } \\
\text { Length, } \\
\text { mm }\end{array}$ \\
\hline & & & & & & & & & & & & & 5.806 \\
\hline 1 & 69 & 212 & 205 & 250 & 0.17 & 0.50 & 0.50 & 0 & 12.4 & 10.3 & $1.71 \mathrm{E}-08$ & 28.1 & 5.923 \\
\hline $2 a$ & 74 & 212 & 205 & 250 & 0.28 & 0.50 & 0.50 & 0 & 12.3 & 8.9 & $3.11 \mathrm{E}-09$ & 28.0 & 5.956 \\
\hline $2 b$ & 144 & 214 & 201 & 250 & 0.30 & 0.50 & 0.50 & 0 & 12.8 & 8.9 & $2.70 \mathrm{E}-09$ & 28.0 & 5.972 \\
\hline $2 c$ & 165 & 214 & 201 & 250 & 0.32 & 0.50 & 0.50 & 0 & 13.5 & 9.2 & $1.06 \mathrm{E}-08$ & 27.8 & 6.036 \\
\hline $3 a$ & 195 & 213 & 195 & 250 & 0.52 & 60 & 4 & 0 & 14.3 & 6.9 & $4.30 \mathrm{E}-11$ & 27.8 & 6.045 \\
\hline $3 b^{*}$ & 215 & 213 & 195 & 250 & 0.52 & 60 & 4 & 0 & 15.3 & 7.4 & $1.61 \mathrm{E}-09$ & 27.6 & 6.118 \\
\hline $4^{*}$ & 260 & 209 & 196 & 250 & 0.69 & 300 & 4 & 0 & 14.7 & 4.6 & $3.34 \mathrm{E}-10$ & 27.5 & 6.173 \\
\hline $5^{*}$ & 305 & 207 & 196 & 250 & 0.69 & 1,000 & 12 & 0 & 14.7 & 4.6 & $3.89 \mathrm{E}-10$ & 27.4 & 6.235 \\
\hline 6 & 355 & 206 & 196 & 250 & 0.70 & 60 & 12 & 0 & 15.3 & 4.6 & $3.10 \mathrm{E}-11$ & 27.3 & 6.276 \\
\hline 7 & 378 & 205 & 199 & 250 & 0.71 & 60 & 12 & 0 & 16.6 & 4.8 & $8.03 \mathrm{E}-11$ & 27.2 & 6.285 \\
\hline 8 & 482 & 199 & 193 & 250 & 0.51 & 30 & 4 & 0 & 16.6 & 8.1 & $8.57 \mathrm{E}-11$ & 27.2 & 6.308 \\
\hline
\end{tabular}

${ }^{\mathrm{a}}$ Grand Gulf H5 SA weld top shell HAZ, irradiated to $5.0 \times 10^{20} \mathrm{n} \mathrm{cm}^{-2}(0.75 \mathrm{dpa})$ at $\approx 297^{\circ} \mathrm{C}$.

${ }^{\mathrm{b}} \mathrm{An}$ asterisk indicates environmental enhancement of growth rates under cyclic loading.

${ }^{\mathrm{c}}$ Represents values in the effluent. Conductivity was $\approx 0.07$ and $0.2 \mu \mathrm{S} / \mathrm{cm}$ in feedwater and effluent, respectively.

${ }^{\mathrm{d}}$ Based on ASTM 1681 criterion and flow stress.

e The specimen was not fractured and the DC potential drop measurements were not corrected. 
A.10 Specimen GG5T-B of Type 304L SA weld HAZ as-welded and irradiated to $0.75 \mathrm{dpa}$, Test CGRI-16.

Table A10. Crack growth results for Specimen GG5T-Ba of Type $304 \mathrm{~L} \mathrm{HAZ} \mathrm{in} \mathrm{high-purity} \mathrm{water} \mathrm{at} 289^{\circ} \mathrm{C}$.

\begin{tabular}{|c|c|c|c|c|c|c|c|c|c|c|c|c|c|}
\hline $\begin{array}{c}\text { Test } \\
\text { Period }^{\mathrm{b}}\end{array}$ & $\begin{array}{c}\text { Test } \\
\text { Time, } \\
\mathrm{h}\end{array}$ & $\begin{array}{c}\mathrm{EC} \\
\mathrm{mV} \\
\mathrm{Pt} \\
\end{array}$ & $\begin{array}{l}\mathrm{P}, \mathrm{c} \\
\text { SHE) } \\
\text { Steel }\end{array}$ & $\begin{array}{c}\mathrm{O}_{2} \\
\text { Conc., } \\
\text { ppb }\end{array}$ & $\begin{array}{c}\mathrm{R} \\
\text { Load } \\
\text { Ratio } \\
\end{array}$ & $\begin{array}{c}\text { Rise } \\
\text { Time, } \\
\mathrm{s}\end{array}$ & $\begin{array}{c}\text { Return } \\
\text { Time, } \\
\text { s }\end{array}$ & $\begin{array}{c}\text { Hold } \\
\text { Time, } \\
\text { s }\end{array}$ & $\begin{array}{c}\mathrm{K}_{\max } \\
\mathrm{MPa} \mathrm{m}^{1 / 2}\end{array}$ & $\begin{array}{c}\Delta \mathrm{K}, \\
\mathrm{MPa} \mathrm{m}^{1 / 2}\end{array}$ & $\begin{array}{c}\text { Growth } \\
\text { Rate, } \\
\mathrm{m} / \mathrm{s}\end{array}$ & $\begin{array}{c}\text { Allowed } \\
\mathrm{K}_{\max }{ }^{\mathrm{d}} \\
\mathrm{MPa} \mathrm{m}^{1 / 2}\end{array}$ & $\begin{array}{c}\text { Crack } \\
\text { Length, } \\
\text { mm }\end{array}$ \\
\hline & & & & & & & & & & & & & 5.823 \\
\hline Pre & 81 & 225 & 211 & 400 & 0.20 & 0.50 & 0.50 & 0 & 13.8 & 11.0 & 7.24E-09 & 28.1 & 5.930 \\
\hline 1 & 105 & 218 & 200 & 400 & 0.30 & 0.50 & 0.50 & 0 & 13.0 & 9.1 & $4.59 \mathrm{E}-09$ & 28.0 & 5.982 \\
\hline $2 a$ & 122 & 216 & 206 & 350 & 0.50 & 60 & 4 & 0 & 12.8 & 6.4 & negligible & 28.0 & 5.980 \\
\hline $2 b^{*}$ & 154 & 214 & 199 & 350 & 0.51 & 30 & 4 & 0 & 14.4 & 7.1 & $9.13 \mathrm{E}-10$ & 27.8 & 6.075 \\
\hline $3^{*}$ & 221 & 211 & 199 & 350 & 0.49 & 300 & 4 & 0 & 14.7 & 7.5 & $2.82 \mathrm{E}-10$ & 27.6 & 6.155 \\
\hline $4 *$ & 296 & 204 & 200 & 350 & 0.70 & 300 & 4 & 0 & 14.8 & 4.4 & $2.35 \mathrm{E}-10$ & 27.4 & 6.229 \\
\hline $5^{*}$ & 362 & 229 & 200 & 350 & 0.68 & 1,000 & 12 & 0 & 14.7 & 4.7 & $2.98 \mathrm{E}-10$ & 27.2 & 6.305 \\
\hline 6 & 433 & 201 & 176 & 350 & 0.69 & 300 & 12 & 3600 & 14.7 & 4.6 & $6.75 \mathrm{E}-10$ & 26.7 & 6.501 \\
\hline 7 & 530 & 220 & 204 & 350 & 1.00 & - & - & - & 15.0 & - & $4.24 \mathrm{E}-10$ & 26.4 & 6.644 \\
\hline 8 & 584 & 215 & 202 & 350 & 0.69 & 300 & 12 & 9700 & 15.2 & 4.7 & $5.62 \mathrm{E}-10$ & 26.1 & 6.774 \\
\hline 9 & 724 & -532 & -285 & $<50$ & 0.69 & 300 & 12 & 9700 & 14.9 & 4.6 & negligible & 26.0 & 6.777 \\
\hline 10 & 893 & -533 & -530 & $<50$ & 0.69 & 300 & 122 & 0 & 15.0 & 4.6 & negligible & 26.0 & 6.781 \\
\hline
\end{tabular}

${ }^{\mathrm{a}}$ Grand Gulf H5 SA weld top shell HAZ, irradiated to $5.0 \times 10^{20} \mathrm{n} \mathrm{cm}^{-2}(0.75 \mathrm{dpa})$ at $\approx 297^{\circ} \mathrm{C}$.

${ }^{\mathrm{b}} \mathrm{An}$ asterisk indicates environmental enhancement of growth rates under cyclic loading.

${ }^{\mathrm{c}}$ Represents values in the effluent. Conductivity was $\approx 0.07$ and $0.2 \mu \mathrm{S} / \mathrm{cm}$ in feedwater and effluent, respectively.

${ }^{\mathrm{d}}$ Based on ASTM 1681 criterion and flow stress.

${ }^{\mathrm{e}}$ The difference between the measured crack extension and that determined from the DC potential drop measurements was $<5 \%$.

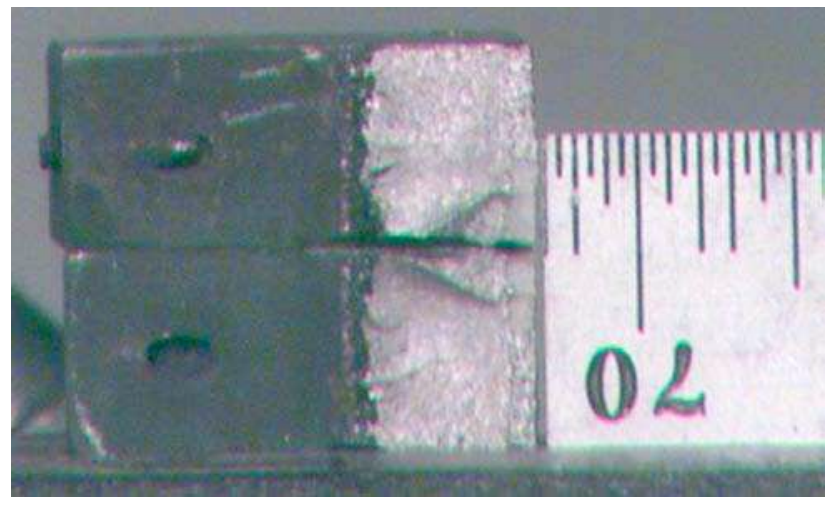

Figure A9.

Photomicrograph of the fracture surface of Specimen GG5T-B. 
A.11 Specimen 85-1A-TT of Type 304 SMA weld HAZ thermally treated and irradiated to 0.75 dpa, Test CGRI-18.

Table A11. Crack growth results for Specimen 85-1A-TTa of Type 304 SS SMA weld HAZ in high-purity water at $289^{\circ} \mathrm{C}$.

\begin{tabular}{|c|c|c|c|c|c|c|c|c|c|c|c|c|c|}
\hline $\begin{array}{c}\text { Test } \\
\text { Period }^{b}\end{array}$ & $\begin{array}{c}\text { Test } \\
\text { Time, } \\
\mathrm{h}\end{array}$ & $\begin{array}{c}\mathrm{E} \\
\mathrm{mV} \\
\mathrm{Pt}\end{array}$ & $\begin{array}{l}\mathrm{P}, \mathrm{c} \\
\text { SHE) } \\
\text { Steel }\end{array}$ & $\begin{array}{c}\mathrm{O}_{2} \\
\text { Conc., } \\
\text { ppb }\end{array}$ & $\begin{array}{c}\text { R } \\
\text { Load } \\
\text { Ratio }\end{array}$ & $\begin{array}{c}\text { Rise } \\
\text { Time, } \\
\text { s }\end{array}$ & $\begin{array}{c}\text { Return } \\
\text { Time, } \\
\text { s }\end{array}$ & $\begin{array}{c}\text { Hold } \\
\text { Time, } \\
\text { s }\end{array}$ & $\begin{array}{c}\mathrm{K}_{\max }, \\
\mathrm{MPa} \mathrm{m}^{1 / 2}\end{array}$ & $\begin{array}{c}\Delta \mathrm{K}, \\
\mathrm{MPa} \mathrm{m}^{1 / 2}\end{array}$ & $\begin{array}{c}\text { Growth } \\
\text { Rate, } \\
\mathrm{m} / \mathrm{s}\end{array}$ & $\begin{array}{c}\text { Allowed } \\
\mathrm{K}_{\max },{ }^{\mathrm{d}} \\
\mathrm{MPa} \mathrm{m}^{1 / 2}\end{array}$ & $\begin{array}{c}\text { Crack } \\
\text { Length, } \\
\mathrm{mm}\end{array}$ \\
\hline & & & & & & & & & & & & & $\begin{array}{l}5.837 \\
5.065\end{array}$ \\
\hline $\begin{array}{l}\text { Pre } a \\
\text { Pre } b\end{array}$ & $\begin{array}{c}98 \\
101\end{array}$ & $\begin{array}{l}229 \\
228\end{array}$ & $\begin{array}{l}163 \\
161\end{array}$ & $\begin{array}{l}200 \\
200\end{array}$ & $\begin{array}{l}0.17 \\
0.24\end{array}$ & $\begin{array}{l}0.25 \\
0.50\end{array}$ & $\begin{array}{l}0.25 \\
0.50\end{array}$ & $\begin{array}{l}0 \\
0\end{array}$ & $\begin{array}{l}13.9 \\
13.3\end{array}$ & $\begin{array}{l}11.6 \\
10.1\end{array}$ & $\begin{array}{l}2.64 \mathrm{E}-08 \\
2.10 \mathrm{E}-08\end{array}$ & $\begin{array}{l}29.8 \\
29.6\end{array}$ & $\begin{array}{l}5.965 \\
6.065\end{array}$ \\
\hline $1 \mathrm{a}$ & 145 & 213 & 166 & 200 & 0.50 & 60 & 4 & 0 & 14.6 & 7.3 & negligible & 29.6 & 6.065 \\
\hline $1 b^{*}$ & 217 & 203 & 175 & 200 & 0.50 & 1,000 & 4 & 0 & 15.1 & 7.6 & $4.80 \mathrm{E}-10$ & 29.5 & 6.100 \\
\hline $2^{*}$ & 262 & 201 & 178 & 250 & 0.70 & 300 & 4 & 0 & 16.1 & 4.8 & $3.55 \mathrm{E}-10$ & 29.2 & 6.204 \\
\hline $3^{*}$ & 314 & 199 & 172 & 250 & 0.71 & 1,000 & 12 & 0 & 16.4 & 4.7 & $3.37 \mathrm{E}-10$ & 29.1 & 6.261 \\
\hline 4 & 411 & 197 & 182 & 250 & 0.70 & 300 & 12 & 3600 & 16.6 & 5.0 & $2.55 \mathrm{E}-10$ & 28.8 & 6.358 \\
\hline 5 & 479 & 203 & 188 & 250 & 0.70 & 300 & 12 & 9700 & 16.7 & 5.0 & $1.74 \mathrm{E}-10$ & 28.7 & 6.404 \\
\hline 6 & 605 & 175 & 185 & 250 & 0.70 & 300 & 12 & 9700 & 18.7 & 5.6 & $2.78 \mathrm{E}-10$ & 28.4 & 6.520 \\
\hline 7 & 746 & -526 & -258 & $<30$ & 0.70 & 300 & 12 & 9700 & 19.3 & 5.8 & $5.73 \mathrm{E}-11$ & 28.3 & 6.550 \\
\hline
\end{tabular}

${ }^{a}$ Laboratory-prepared SMA weld $\mathrm{HAZ}$ thermally treated $24 \mathrm{~h}$ at $500^{\circ} \mathrm{C}$, irradiated to $5.0 \times 10^{20} \mathrm{n} \mathrm{cm}^{-2}(0.75 \mathrm{dpa})$ at $\approx 297^{\circ} \mathrm{C}$.

${ }^{\mathrm{b}} \mathrm{An}$ asterisk indicates environmental enhancement of growth rates under cyclic loading.

${ }^{\mathrm{c}}$ Represents values in the effluent. Conductivity was $\approx 0.07$ and $0.2 \mu \mathrm{S} / \mathrm{cm}$ in feedwater and effluent, respectively.

${ }^{\mathrm{d}}$ Based on ASTM 1681 criterion and flow stress.

${ }^{\mathrm{e}}$ The difference between the measured crack extension and that determined from the DC potential drop measurements was $<5 \%$.

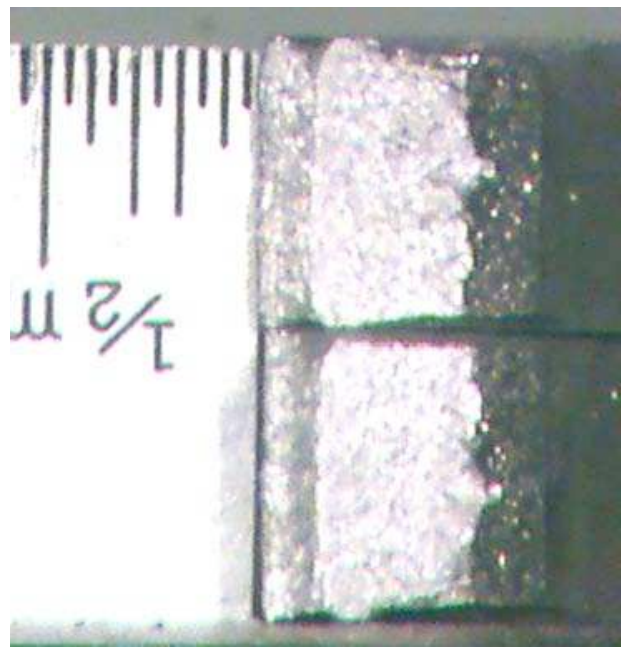

Figure A10.

Photomicrograph of the fracture surface of Specimen 85-1A TT. 
A.12 Specimen 85-7A of Type 304 SMA weld HAZ as-welded and irradiated to 0.75 dpa, Test CGRI-20.

Table A12. Crack growth data for specimen $85-7 \mathrm{~A}$ of SS SMA Weld HAZ in high-purity water at $289^{\circ} \mathrm{C}$.

\begin{tabular}{|c|c|c|c|c|c|c|c|c|c|c|c|c|c|}
\hline $\begin{array}{c}\text { Test } \\
\text { Period }^{b}\end{array}$ & $\begin{array}{c}\text { Test } \\
\text { Time, } \\
\mathrm{h}\end{array}$ & $\begin{array}{c}\mathrm{E} \\
\mathrm{mV} \\
\mathrm{Pt} \\
\end{array}$ & $\begin{array}{l}\mathrm{P}, \mathrm{c} \\
\text { SHE) } \\
\text { Steel }\end{array}$ & $\begin{array}{c}\mathrm{O}_{2} \\
\text { Conc., } \\
\text { ppb }\end{array}$ & $\begin{array}{c}\mathrm{R} \\
\text { Load } \\
\text { Ratio } \\
\end{array}$ & $\begin{array}{c}\text { Rise } \\
\text { Time, } \\
\mathrm{s} \\
\end{array}$ & $\begin{array}{c}\text { Return } \\
\text { Time, } \\
\mathrm{s} \\
\end{array}$ & $\begin{array}{c}\text { Hold } \\
\text { Time, } \\
\text { s } \\
\end{array}$ & $\begin{array}{c}\mathrm{K}_{\max }, \\
\mathrm{MPa} \mathrm{m}^{1 / 2}\end{array}$ & $\begin{array}{c}\Delta \mathrm{K}, \\
\mathrm{MPa} \mathrm{m}^{1 / 2}\end{array}$ & $\begin{array}{c}\text { Growth } \\
\text { Rate, } \\
\mathrm{m} / \mathrm{s}\end{array}$ & $\begin{array}{c}\text { Allowed } \\
\mathrm{K}_{\max },{ }^{d} \\
\mathrm{MPa} \mathrm{m}^{1 / 2}\end{array}$ & $\begin{array}{c}\text { Crack } \\
\text { Length, } \\
\mathrm{mm}\end{array}$ \\
\hline & & & & & & & & & & & & & 5.806 \\
\hline Pre & 166 & 261 & 224 & 500 & 0.23 & 0.50 & 0.50 & 0 & 15.9 & 12.2 & $2.77 \mathrm{E}-08$ & 29.7 & 5.951 \\
\hline 1 & 187 & 258 & 225 & 500 & 0.50 & 60 & 4 & 0 & 15.8 & 7.9 & negligible & 29.7 & 5.969 \\
\hline 2 & 428 & 244 & 219 & 500 & 0.51 & 300 & 4 & 0 & 15.7 & 7.7 & $2.09 \mathrm{E}-11$ & 29.6 & 5.999 \\
\hline 3 & 499 & 245 & 221 & 500 & 0.50 & 1,000 & 12 & 0 & 16.4 & 8.2 & negligible & 29.6 & 5.998 \\
\hline 4 & 608 & 234 & 211 & 500 & 0.53 & 1,000 & 12 & 0 & 17.2 & 8.1 & $4.65 \mathrm{E}-11$ & 29.6 & 6.013 \\
\hline $5^{*}$ & 763 & 229 & 209 & 500 & 0.50 & 1,000 & 12 & 0 & 18.3 & 9.1 & $4.28 \mathrm{E}-10$ & 29.1 & 6.219 \\
\hline $6^{*}$ & 788 & 231 & 212 & 500 & 0.50 & 1,000 & 12 & 3600 & 18.6 & 9.3 & $9.51 \mathrm{E}-10$ & 28.8 & 6.310 \\
\hline 7 & 845 & 221 & 214 & 500 & 1.00 & - & - & - & 19.4 & - & $9.46 \mathrm{E}-10$ & 28.3 & 6.502 \\
\hline 8 & 1100 & -527 & -252 & $<50$ & 1.00 & - & - & - & 19.8 & - & $1.55 \mathrm{E}-11$ & 28.0 & 6.625 \\
\hline
\end{tabular}

${ }^{\mathrm{a}}$ Laboratory-prepared SMA weld HAZ, irradiated to $0.5 \times 10^{21} \mathrm{n} \mathrm{cm}^{-2}(0.75 \mathrm{dpa})$ at $\approx 297^{\circ} \mathrm{C}$.

$\mathrm{b}_{\mathrm{An}}$ asterisk indicates environmental enhancement of growth rates under cyclic loading.

${ }^{\mathrm{c}}$ Represents values in the effluent. Conductivity was $\approx 0.07$ and $0.3 \mu \mathrm{S} / \mathrm{cm}$ in feedwater and effluent, respectively.

${ }^{\mathrm{d}}$ Based on ASTM 1681 criterion and flow stress.

eActual crack extension was $80 \%$ greater than the value determined from the DC potential drop measurements.

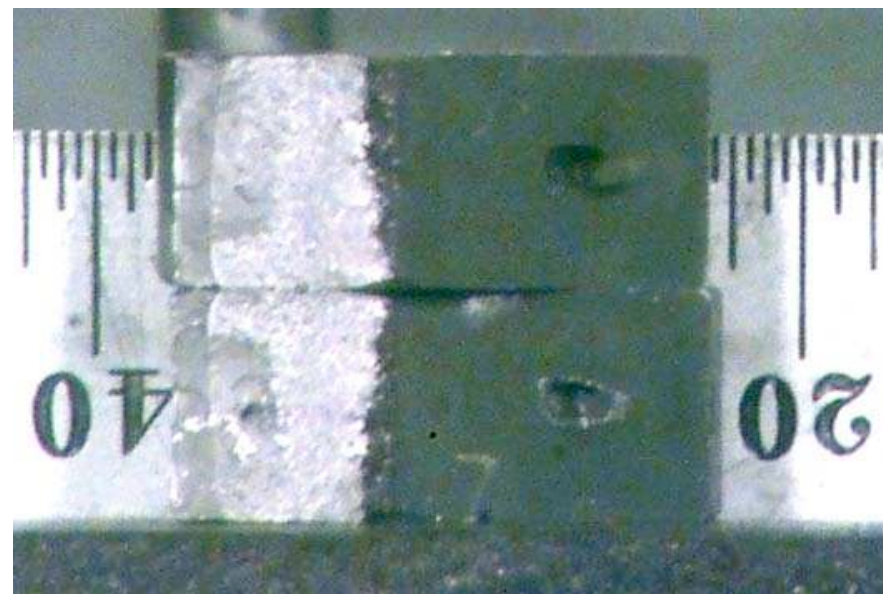

Figure A11.

Photomicrograph of the fracture surface of Specimen 85-7A. 
Appendix B 


\section{Appendix B: Fracture Toughness J-R Curve Data for Irradiated Austenitic SSs}

Table B1. Fracture toughness data for specimen $\mathrm{C} 19-\mathrm{A}$ in air at $289^{\circ} \mathrm{C}$.

$\begin{array}{llll}\text { Test Number } & : \text { JRI-21 } & \text { Test Temp. } & : 288^{\circ} \mathrm{C} \\ \text { Test Environment } & : \text { Air } & & \\ \text { Material Type } & : \text { Type 304 SS } & \text { Heat Number } & : \text { C19 } \\ \text { Aging Temp. } & :- & \text { Aging Time } & :- \\ \text { Irradiation Temp. } & : 288^{\circ} \mathrm{C} & \text { Fluence } & : 0.30 \times 10^{21} \mathrm{n} / \mathrm{cm}^{2}(0.45 \mathrm{dpa}) \\ \text { Thickness } & : 6.500 \mathrm{~mm} & \text { Net Thickness } & : 5.850 \mathrm{~mm} \\ \text { Width } & : 12.000 \mathrm{~mm} & \text { Flow Stress } & : 618 \mathrm{MPa} \\ \text { Modulus E } & : 175 \mathrm{GPa} & \text { Effective Flow Stress } & : 479 \mathrm{MPa} \\ \text { Initial Crack } & : 6.000 \mathrm{~mm} & \text { Init. a/W } & : 0.500 \\ \text { Final Crack } & : 8.843 \mathrm{~mm} & \text { Final a/W } & : 0.737\end{array}$

\begin{tabular}{|c|c|c|c|c|}
\hline No. & Load $(\mathrm{kN})$ & Deflection $(\mathrm{mm})$ & $\mathrm{J}\left(\mathrm{kJ} / \mathrm{m}^{2}\right)$ & $\Delta \mathrm{a}(\mathrm{mm})$ \\
\hline 0 & 0.0881 & 0.000 & 0.0 & 0.000 \\
1 & 1.6218 & 0.154 & 11.4 & 0.006 \\
2 & 2.3126 & 0.304 & 38.3 & 0.021 \\
3 & 2.4287 & 0.499 & 76.9 & 0.041 \\
4 & 2.5052 & 0.696 & 117.2 & 0.062 \\
5 & 2.5640 & 0.895 & 159.1 & 0.084 \\
6 & 2.6182 & 1.094 & 201.9 & 0.107 \\
7 & 2.6583 & 1.295 & 245.6 & 0.130 \\
8 & 2.6729 & 1.395 & 267.5 & 0.140 \\
9 & 2.6872 & 1.497 & 290.1 & 0.153 \\
10 & 2.7023 & 1.597 & 312.3 & 0.164 \\
11 & 2.7005 & 1.699 & 334.4 & 0.179 \\
12 & 2.7059 & 1.802 & 357.6 & 0.188 \\
13 & 2.7045 & 1.902 & 380.1 & 0.196 \\
14 & 2.7076 & 2.004 & 402.3 & 0.213 \\
15 & 2.7054 & 2.104 & 427.3 & 0.227 \\
16 & 2.6978 & 2.207 & 450.7 & 0.232 \\
17 & 2.6796 & 2.310 & 472.3 & 0.251 \\
18 & 2.6663 & 2.414 & 484.5 & 0.336 \\
19 & 2.6449 & 2.516 & 496.7 & 0.415 \\
20 & 2.6129 & 2.619 & 507.6 & 0.502 \\
21 & 2.5889 & 2.723 & 518.5 & 0.587 \\
22 & 2.5617 & 2.827 & 527.8 & 0.681 \\
23 & 2.5261 & 2.931 & 540.6 & 0.748 \\
24 & 2.4599 & 3.037 & 551.9 & 0.829 \\
25 & 2.4252 & 3.143 & 561.6 & 0.913 \\
26 & 2.3949 & 3.246 & 572.0 & 0.987 \\
27 & 2.3544 & 3.351 & 582.6 & 1.062 \\
28 & 2.3318 & 3.454 & 592.0 & 1.138 \\
29 & 2.2673 & 3.561 & 600.8 & 1.220 \\
30 & 2.2183 & 3.666 & 607.3 & 1.307 \\
31 & 2.1663 & 3.771 & 613.2 & 1.393 \\
\hline
\end{tabular}

Crack extension determined from DC potential drop method.

Power-Law Fit

DC Potential Method

Coeff. C : $575 \mathrm{~kJ} / \mathrm{m}^{2}$

$$
\mathbf{J}=\mathbf{C}(\Delta \mathbf{a})^{\mathrm{n}}
$$

$\mathrm{J}_{\text {Ic }} \quad: 503 \mathrm{~kJ} / \mathrm{m}^{2} \quad$ (17 Data)

$\begin{array}{lll}\text { Exponent } \mathrm{n} & : 0.17 \quad \text { Fit Coeff. } \mathrm{R} & : 0.974\end{array}$ 
Table B2. Fracture toughness data for specimen C19-B in air at $289^{\circ} \mathrm{C}$.

$\begin{array}{llll}\text { Test Number } & : \text { JRI-23 } & \text { Test Temp. } & : 288^{\circ} \mathrm{C} \\ \text { Test Environment } & : \text { Air } & & \\ \text { Material Type } & : \text { Type 304 SS } & \text { Heat Number } & : \text { C19 } \\ \text { Aging Temp. } & :- & \text { Aging Time } & :- \\ \text { Irradiation Temp. } & : 288^{\circ} \mathrm{C} & \text { Fluence } & : 0.90 \times 10^{21} \mathrm{n} / \mathrm{cm}^{2}(1.35 \mathrm{dpa}) \\ \text { Thickness } & : 6.500 \mathrm{~mm} & \text { Net Thickness } & : 5.850 \mathrm{~mm} \\ \text { Width } & : 12.000 \mathrm{~mm} & \text { Flow Stress } & : 760 \mathrm{MPa} \\ \text { Modulus E } & : 175 \mathrm{GPa} & \text { Effective Flow Stress } & : 550 \mathrm{MPa} \\ \text { Initial Crack } & : 6.000 \mathrm{~mm} & \text { Init. a/W } & : 0.500 \\ \text { Final Crack } & : 9.399 \mathrm{~mm} & \text { Final a/W } & : 0.783\end{array}$

\begin{tabular}{|c|c|c|c|c|}
\hline No. & Load $(\mathrm{kN})$ & Deflection $(\mathrm{mm})$ & $\mathrm{J}\left(\mathrm{kJ} / \mathrm{m}^{2}\right)$ & $\Delta \mathrm{a}(\mathrm{mm})$ \\
\hline 0 & 0.0876 & 0.000 & 0.0 & 0.000 \\
1 & 1.9710 & 0.125 & 8.6 & 0.004 \\
2 & 2.6302 & 0.176 & 17.1 & 0.009 \\
3 & 3.1849 & 0.236 & 24.3 & 0.012 \\
4 & 3.5439 & 0.311 & 48.7 & 0.024 \\
5 & 3.6431 & 0.404 & 73.8 & 0.035 \\
6 & 3.6364 & 0.519 & 106.2 & 0.050 \\
7 & 3.5893 & 0.624 & 137.7 & 0.065 \\
8 & 3.5270 & 0.729 & 168.2 & 0.078 \\
9 & 3.4687 & 0.836 & 201.8 & 0.094 \\
10 & 3.4260 & 0.941 & 230.1 & 0.106 \\
11 & 3.311 & 1.047 & 255.7 & 0.118 \\
12 & 3.2659 & 1.153 & 277.6 & 0.210 \\
13 & 3.1947 & 1.259 & 305.5 & 0.309 \\
14 & 3.1244 & 1.366 & 331.4 & 0.397 \\
15 & 3.0582 & 1.472 & 354.1 & 0.479 \\
16 & 2.9590 & 1.581 & 380.7 & 0.566 \\
17 & 2.8802 & 1.689 & 401.5 & 0.657 \\
18 & 2.7935 & 1.796 & 413.0 & 0.746 \\
19 & 2.7094 & 1.903 & 437.0 & 0.832 \\
20 & 2.6471 & 2.009 & 457.9 & 0.918 \\
21 & 2.5386 & 2.169 & 483.0 & 1.040 \\
22 & 2.4310 & 2.329 & 505.5 & 1.169 \\
23 & 2.2842 & 2.491 & 521.3 & 1.301 \\
24 & 2.1836 & 2.649 & 535.8 & 1.416 \\
25 & 2.0595 & 2.811 & 547.5 & 1.550 \\
26 & 1.9510 & 2.970 & 550.1 & 1.694 \\
27 & 1.8340 & 3.131 & 557.1 & 1.823 \\
28 & 1.7433 & 3.290 & 566.9 & 1.939 \\
29 & 1.6570 & 3.449 & 572.2 & 2.041 \\
\hline
\end{tabular}

Crack extension determined from DC potential drop method.

Power-Law Fit

DC Potential Method

Coeff. C $\quad: 438 \mathrm{~kJ} / \mathrm{m}^{2}$
$\mathbf{J}=\mathbf{C}(\Delta \mathbf{a})^{\mathrm{n}}$

$\mathrm{J}_{\text {Ic }} \quad: 308 \mathrm{~kJ} / \mathrm{m}^{2} \quad$ (17 Data)

Exponent $\mathrm{n} \quad: 0.33$
Fit Coeff. $\mathrm{R} \quad: 0.996$ 
Table B3. Fracture toughness data for specimen $\mathrm{C} 19-\mathrm{C}$ in air at $289^{\circ} \mathrm{C}$.

$\begin{array}{llll}\text { Test Number } & : \text { JRI-33 } & \text { Test Temp. } & : 288^{\circ} \mathrm{C} \\ \text { Test Environment } & : \text { Air } & & \\ \text { Material Type } & : \text { Type 304 SS } & \text { Heat Number } & : \text { C19 } \\ \text { Aging Temp. } & :- & \text { Aging Time } & :- \\ \text { Irradiation Temp. } & : 288^{\circ} \mathrm{C} & \text { Fluence } & : 2.00 \times 10^{21} \mathrm{n} / \mathrm{cm}^{2}(3.00 \mathrm{dpa}) \\ \text { Thickness } & : 6.500 \mathrm{~mm} & \text { Net Thickness } & : 5.850 \mathrm{~mm} \\ \text { Width } & : 11.996 \mathrm{~mm} & \text { Flow Stress } & : 794 \mathrm{MPa} \\ \text { Modulus E } & : 175 \mathrm{GPa} & \text { Effective Flow Stress } & : 567 \mathrm{MPa} \\ \text { Initial Crack } & : 6.000 \mathrm{~mm} & \text { Init. a/W } & : 0.500 \\ \text { Final Crack } & : 10.359 \mathrm{~mm} & \text { Final a/W } & : 0.863\end{array}$

\begin{tabular}{|c|c|c|c|c|}
\hline No. & Load $(\mathrm{kN})$ & Deflection $(\mathrm{mm})$ & $\mathrm{J}\left(\mathrm{kJ} / \mathrm{m}^{2}\right)$ & $\Delta \mathrm{a}(\mathrm{mm})$ \\
\hline 0 & 0.0890 & 0.000 & 0.0 & 0.000 \\
1 & 0.6210 & 0.040 & 1.0 & -0.254 \\
2 & 0.9301 & 0.061 & 1.9 & -0.011 \\
3 & 1.2508 & 0.082 & 3.8 & 0.047 \\
4 & 1.5862 & 0.106 & 6.5 & -0.034 \\
5 & 1.9114 & 0.129 & -0.078 \\
6 & 3.6676 & 0.350 & -0.5 & -0.044 \\
7 & 3.7183 & 0.397 & 74.7 & 0.038 \\
8 & 3.6907 & 0.449 & 92.2 & 0.003 \\
9 & 3.6266 & 0.504 & 106.9 & 0.006 \\
10 & 3.5461 & 0.558 & 136.7 & 0.072 \\
11 & 3.4118 & 0.668 & 165.4 & 0.102 \\
12 & 3.2316 & 0.781 & 187.5 & 0.168 \\
13 & 3.0697 & 0.893 & 209.7 & 0.311 \\
14 & 2.9260 & 1.004 & 225.4 & 0.387 \\
15 & 2.7459 & 1.118 & 236.9 & 0.762 \\
16 & 2.5693 & 1.232 & 245.3 & 0.956 \\
17 & 2.4256 & 1.343 & 253.6 & 1.122 \\
18 & 2.2944 & 1.453 & 266.4 & 1.230 \\
19 & 2.1663 & 1.564 & 277.5 & 1.351 \\
20 & 2.0733 & 1.672 & 294.9 & 1.445 \\
21 & 1.9630 & 1.780 & 303.1 & 1.523 \\
22 & 1.8709 & 1.889 & 316.1 & 1.599 \\
23 & 1.7949 & 1.997 & 327.2 & 1.680 \\
24 & 1.7001 & 2.105 & 337.3 & 1.757 \\
25 & 1.6249 & 2.212 & \\
\hline
\end{tabular}

Crack extension determined from elastic unloading compliance method.

Power-Law Fit

DC Potential Method

Coeff. C : $265 \mathrm{~kJ} / \mathrm{m}^{2}$

$$
\mathbf{J}=\mathbf{C}(\Delta \mathbf{a})^{\mathrm{n}}
$$

$\mathrm{J}_{\text {Ic }} \quad: 184 \mathrm{~kJ} / \mathrm{m}^{2} \quad$ (15 Data)

$\begin{array}{lll}\text { Exponent } \mathrm{n} & : 0.29 \quad \text { Fit Coeff. } \mathrm{R} & : 0.967\end{array}$ 
Table B4. Fracture toughness data for specimen C16-A in air at $289^{\circ} \mathrm{C}$.

$\begin{array}{llll}\text { Test Number } & : \text { JRI-26 } & \text { Test Temp. } & : 288^{\circ} \mathrm{C} \\ \text { Test Environment } & : \text { Air } & & \\ \text { Material Type } & : \text { Type 316L SS } & \text { Heat Number } & : \text { C16 } \\ \text { Aging Temp. } & :- & \text { Aging Time } & :- \\ \text { Irradiation Temp. } & : 288^{\circ} \mathrm{C} & \text { Fluence } & : 0.90 \times 10^{21} \mathrm{n} / \mathrm{cm}^{2}(1.35 \mathrm{dpa}) \\ \text { Thickness } & : 6.500 \mathrm{~mm} & \text { Net Thickness } & : 5.850 \mathrm{~mm} \\ \text { Width } & : 12.000 \mathrm{~mm} & \text { Flow Stress } & : 590 \mathrm{MPa} \\ \text { Modulus E } & : 175 \mathrm{GPa} & \text { Effective Flow Stress } & : 463 \mathrm{MPa} \\ \text { Initial Crack } & : 6.000 \mathrm{~mm} & \text { Init. a/W } & : 0.500 \\ \text { Final Crack } & : 8.730 \mathrm{~mm} & \text { Final a/W } & : 0.728\end{array}$

\begin{tabular}{|c|c|c|c|c|}
\hline No. & Load $(\mathrm{kN})$ & Deflection $(\mathrm{mm})$ & $\mathrm{J}\left(\mathrm{kJ} / \mathrm{m}^{2}\right)$ & $\Delta \mathrm{a}(\mathrm{mm})$ \\
\hline 0 & 0.0885 & 0.000 & 0.0 & 0.000 \\
1 & 1.7602 & 0.117 & 8.6 & 0.007 \\
2 & 2.5266 & 0.212 & 24.8 & 0.018 \\
3 & 2.7552 & 0.347 & 53.4 & 0.032 \\
4 & 2.8068 & 0.496 & 86.4 & 0.048 \\
5 & 2.8104 & 0.572 & 103.2 & 0.057 \\
6 & 2.8117 & 0.649 & 120.6 & 0.066 \\
7 & 2.8206 & 0.725 & 137.5 & 0.076 \\
8 & 2.8322 & 0.801 & 154.6 & 0.086 \\
9 & 2.8179 & 0.880 & 172.2 & 0.095 \\
10 & 2.8228 & 0.955 & 189.2 & 0.103 \\
11 & 2.8206 & 1.031 & 206.0 & 0.112 \\
12 & 2.8002 & 1.136 & 228.7 & 0.139 \\
13 & 2.8050 & 1.236 & 248.5 & 0.183 \\
14 & 2.7837 & 1.338 & 268.1 & 0.234 \\
15 & 2.7846 & 1.441 & 287.4 & 0.290 \\
16 & 2.7704 & 1.544 & 306.2 & 0.346 \\
17 & 2.7450 & 1.647 & 325.4 & 0.397 \\
18 & 2.7196 & 1.751 & 344.0 & 0.456 \\
19 & 2.6925 & 1.853 & 361.5 & 0.515 \\
20 & 2.6551 & 1.957 & 378.8 & 0.576 \\
21 & 2.6187 & 2.063 & 396.1 & 0.638 \\
22 & 2.5729 & 2.169 & 412.6 & 0.703 \\
23 & 2.5395 & 2.273 & 428.2 & 0.767 \\
24 & 2.5124 & 2.378 & 443.2 & 0.834 \\
25 & 2.4799 & 2.482 & 459.2 & 0.888 \\
26 & 2.4439 & 2.588 & 475.6 & 0.941 \\
27 & 2.3931 & 2.693 & 491.6 & 0.994 \\
28 & 2.3513 & 2.797 & 503.9 & 1.051 \\
29 & 2.2922 & 2.904 & 518.7 & 1.111 \\
30 & 2.2299 & 3.010 & 530.0 & 1.188 \\
31 & 2.1801 & 3.117 & 540.6 & 1.260 \\
32 & 2.1285 & 3.223 & 552.1 & 1.325 \\
33 & 2.0813 & 3.328 & 562.9 & 1.390 \\
34 & 2.0395 & 3.429 & 572.9 & 1.453 \\
\hline
\end{tabular}

Crack extension determined from DC potential drop method.

Power-Law Fit

DC Potential Method

Coeff. C : $488 \mathrm{~kJ} / \mathrm{m}^{2}$
$\mathbf{J}=\mathbf{C}(\Delta \mathbf{a})^{\mathrm{n}}$

$\mathrm{J}_{\mathrm{Ic}} \quad: 312 \mathrm{~kJ} / \mathrm{m}^{2} \quad$ (14 Data)

Exponent $\mathrm{n} \quad: 0.45$
Fit Coeff. $\mathrm{R} \quad: 0.997$ 
Table B5. Fracture toughness data for specimen $85-3 \mathrm{TT}$ in high-purity water at $289^{\circ} \mathrm{C}$.

Test Number : CGRI JR-31 $\quad$ Test Temp. $289^{\circ} \mathrm{C}$

Test Environment : High-purity water with $\approx 300 \mathrm{ppb}$ dissolved oxygen

Material Type : Type 304 SS Heat Number :10285

Aging Temp. $\quad: 600^{\circ} \mathrm{C} \quad$ Aging Time $: 10.5 \mathrm{~h}$

Irradiation Temp. : $297^{\circ} \mathrm{C} \quad$ Fluence $\quad: 1.44 \times 10^{21} \mathrm{n} / \mathrm{cm}^{2}(2.16 \mathrm{dpa})$

Thickness $\quad: 6.523 \mathrm{~mm}$

Net Thickness $\quad: 5.817 \mathrm{~mm}$

Width $\quad: 11.996 \mathrm{~mm}$

Flow Stress $\quad: 725 \mathrm{MPa}$ (Estimated)

Modulus E $\quad: 175 \mathrm{GPa}$

Initial Crack $\quad: 6.161 \mathrm{~mm}$

Effective Flow Stress : $527 \mathrm{MPa}$ (Estimated)

Final Crack $\quad: 8.880 \mathrm{~mm} \quad$ Final a/W $\quad: 740$ (Measured)

\begin{tabular}{|c|c|c|c|c|}
\hline No. & Load $(\mathrm{kN})$ & Deflection $(\mathrm{mm})$ & $\mathrm{J}\left(\mathrm{kJ} / \mathrm{m}^{2}\right)$ & $\Delta \mathrm{a}(\mathrm{mm})$ \\
\hline 0 & 0.000 & 0.000 & 0.0 & 0.000 \\
1 & 0.976 & 0.021 & 0.7 & 0.000 \\
2 & 1.647 & 0.040 & 2.2 & 0.001 \\
3 & 2.259 & 0.074 & 6.5 & 0.003 \\
4 & 2.899 & 0.111 & 12.7 & 0.007 \\
5 & 3.474 & 0.153 & 21.4 & 0.011 \\
6 & 3.938 & 0.207 & 34.3 & 0.017 \\
7 & 4.321 & 0.267 & 50.4 & 0.025 \\
8 & 4.525 & 0.347 & 73.8 & 0.024 \\
9 & 4.583 & 0.443 & 99.5 & 0.142 \\
10 & 4.560 & 0.547 & 128.1 & 0.234 \\
11 & 4.511 & 0.605 & 151.9 & 0.097 \\
12 & 4.490 & 0.708 & 170.6 & 0.354 \\
13 & 4.385 & 0.821 & 200.0 & 0.456 \\
14 & 4.273 & 0.932 & 228.6 & 0.543 \\
15 & 4.182 & 1.044 & 261.8 & 0.553 \\
16 & 4.046 & 1.160 & 290.2 & 0.633 \\
17 & 3.863 & 1.280 & 307.2 & 0.833 \\
18 & 3.761 & 1.394 & 331.6 & 0.923 \\
19 & 3.570 & 1.567 & 356.6 & 1.147 \\
20 & 3.366 & 1.741 & 384.5 & 1.323 \\
21 & 3.154 & 1.914 & 408.9 & 1.499 \\
22 & 2.833 & 2.149 & 432.4 & 1.761 \\
23 & 2.542 & 2.381 & 445.1 & 2.047 \\
24 & 2.340 & 2.605 & 452.8 & 2.317 \\
25 & 2.169 & 2.829 & 469.0 & 2.519 \\
26 & 2.020 & 3.047 & 479.2 & 2.723 \\
\hline
\end{tabular}

Power-Law Fit

DC Potential Method

Coeff. C : $316 \mathrm{~kJ} / \mathrm{m}^{2}$
$\mathbf{J}=\mathbf{C}(\Delta \mathbf{a})^{\mathrm{n}}$

$\mathrm{J}_{\text {Ic }} \quad: 176 \mathrm{~kJ} / \mathrm{m}^{2} \quad$ (18 Data)

Exponent $\mathrm{n} \quad: 0.45$
Fit Coeff. $\mathrm{R}: 0.959$ 
Table B6. Fracture toughness data for specimen $85-\mathrm{XA}$ in high-purity water at $289^{\circ} \mathrm{C}$.

Test Number : CGRI JR-32 Test Temp. $\quad: 289^{\circ} \mathrm{C}$

Test Environment : High-purity water with $\approx 400 \mathrm{ppb}$ dissolved oxygen

Material Type : HAZ of 304 SS SMAW Heat Number : 10285

Aging Temp. :

Irradiation Temp. : $297^{\circ} \mathrm{C}$

Thickness $\quad: 6.502 \mathrm{~mm}$

Aging Time : :-

Width $\quad: 11.981 \mathrm{~mm}$

Fluence $\quad: 1.44 \times 10^{21} \mathrm{n} / \mathrm{cm}^{2}(2.16 \mathrm{dpa})$

Modulus E $\quad: 175 \mathrm{GPa}$

Initial Crack $\quad: 6.263 \mathrm{~mm}$

Net Thickness $\quad: 5.410 \mathrm{~mm}$

Flow Stress $\quad: 725 \mathrm{MPa}$ (Estimated)

Final Crack $\quad: 9.080 \mathrm{~mm}$

Effective Flow Stress : $527 \mathrm{MPa}$ (Estimated)

Init. a/W : 0.523

Final a/W $\quad: 0.758$ (Measured)

\begin{tabular}{|c|c|c|c|c|}
\hline No. & Load $(\mathrm{kN})$ & Deflection $(\mathrm{mm})$ & $\mathrm{J}\left(\mathrm{kJ} / \mathrm{m}^{2}\right)$ & $\Delta \mathrm{a}(\mathrm{mm})$ \\
\hline 0 & 0.000 & 0.000 & 0.0 & 0.000 \\
1 & 0.911 & 0.040 & 1.2 & 0.001 \\
2 & 1.479 & 0.070 & 3.7 & 0.002 \\
3 & 2.104 & 0.105 & 8.1 & 0.004 \\
4 & 2.689 & 0.142 & 14.4 & 0.007 \\
5 & 3.249 & 0.189 & 24.2 & 0.012 \\
6 & 3.758 & 0.237 & 36.0 & 0.018 \\
7 & 4.200 & 0.293 & 51.6 & 0.026 \\
8 & 4.536 & 0.360 & 72.4 & 0.038 \\
9 & 4.708 & 0.442 & 95.2 & 0.192 \\
10 & 4.135 & 0.608 & 137.9 & 0.484 \\
11 & 3.833 & 0.686 & 154.8 & 0.652 \\
12 & 3.712 & 0.751 & 168.1 & 0.780 \\
13 & 3.627 & 0.811 & 180.7 & 0.878 \\
14 & 3.431 & 0.932 & 206.5 & 1.041 \\
15 & 3.243 & 1.052 & 231.6 & 1.174 \\
16 & 3.131 & 1.164 & 255.1 & 1.278 \\
17 & 2.994 & 1.278 & 278.7 & 1.372 \\
18 & 2.667 & 1.439 & 291.7 & 1.672 \\
19 & 2.338 & 1.602 & 305.2 & 1.926 \\
20 & 2.055 & 1.759 & 314.5 & 2.161 \\
21 & 1.842 & 1.908 & 320.0 & 2.380 \\
22 & 1.719 & 2.054 & 326.8 & 2.562 \\
23 & 1.630 & 2.190 & 333.7 & 2.714 \\
24 & 1.558 & 2.324 & 346.2 & 2.817 \\
\hline
\end{tabular}

Power-Law Fit

DC Potential Method

Coeff. C : $219 \mathrm{~kJ} / \mathrm{m}^{2}$
$\mathrm{J}=\mathrm{C}(\Delta \mathrm{a})^{\mathrm{n}}$

$\mathrm{J}_{\text {Ic }} \quad: 128 \mathrm{~kJ} / \mathrm{m}^{2} \quad$ (16 Data)

Exponent $\mathrm{n} \quad: 0.43$
Fit Coeff. $\mathrm{R} \quad: 0.902$ 
Table B7. Fracture toughness data for specimen GG6T-A in high-purity water at $289^{\circ} \mathrm{C}$.

Test Number $\quad:$ CGRI JR-35 $\quad$ Test Temp. $\quad 289^{\circ} \mathrm{C}$

Test Environment : High-purity water with $\approx 400 \mathrm{ppb}$ dissolved oxygen

Material Type : Type 304L SAWeld HAZ Heat Number : Grand Gulf core shroud shell

Aging Temp. : : -

Irradiation Temp. : $297^{\circ} \mathrm{C}$

Thickness $\quad: 6.533 \mathrm{~mm}$

Width $\quad: 11.999 \mathrm{~mm}$

Aging Time : :

Fluence $\quad: 1.44 \times 10^{21} \mathrm{n} / \mathrm{cm}^{2}(2.16 \mathrm{dpa})$

Modulus E $\quad: 175 \mathrm{GPa}$

Net Thickness $\quad: 5.791 \mathrm{~mm}$

Initial Crack $\quad: 6.747 \mathrm{~mm}$

Flow Stress $\quad: 711 \mathrm{MPa}$

Final Crack $\quad: 9.412 \mathrm{~mm}$

Effective Flow Stress : $502 \mathrm{MPa}$

Init. $\mathrm{a} / \mathrm{W} \quad: 0.562$

Final a/W : 0.784

\begin{tabular}{|c|c|c|c|c|}
\hline No. & Load $(\mathrm{kN})$ & Deflection $(\mathrm{mm})$ & $\mathrm{J}\left(\mathrm{kJ} / \mathrm{m}^{2}\right)$ & $\Delta \mathrm{a}(\mathrm{mm})$ \\
\hline 0 & 0.000 & 0.000 & 0.0 & 0.000 \\
1 & 0.963 & 0.051 & 1.7 & 0.001 \\
2 & 1.711 & 0.091 & 5.3 & 0.003 \\
3 & 2.295 & 0.129 & 10.6 & 0.006 \\
4 & 2.838 & 0.175 & 18.8 & 0.010 \\
5 & 3.290 & 0.231 & 31.0 & 0.016 \\
6 & 3.544 & 0.283 & 43.5 & 0.023 \\
7 & 3.708 & 0.343 & 59.0 & 0.031 \\
8 & 3.764 & 0.413 & 75.7 & 0.133 \\
9 & 3.762 & 0.487 & 94.3 & 0.205 \\
10 & 3.698 & 0.571 & 114.6 & 0.300 \\
11 & 3.622 & 0.655 & 134.1 & 0.396 \\
12 & 3.502 & 0.743 & 152.9 & 0.521 \\
13 & 3.340 & 0.835 & 172.0 & 0.636 \\
14 & 2.720 & 0.974 & 187.9 & 0.949 \\
15 & 2.426 & 1.082 & 195.7 & 1.200 \\
16 & 2.121 & 1.187 & 200.1 & 1.458 \\
17 & 1.983 & 1.280 & 204.8 & 1.645 \\
18 & 1.742 & 1.383 & 210.3 & 1.828 \\
19 & 1.542 & 1.482 & 206.1 & 2.092 \\
20 & 1.449 & 1.567 & 200.5 & 2.328 \\
21 & 1.349 & 1.654 & 198.7 & 2.516 \\
22 & 1.279 & 1.740 & 199.4 & 2.665 \\
\hline
\end{tabular}

Crack extension determined from DC potential drop method.

Power-Law Fit

DC Potential Method

Coeff. C : $179 \mathrm{~kJ} / \mathrm{m}^{2}$
$\mathbf{J}=\mathbf{C}(\Delta \mathbf{a})^{\mathrm{n}}$

$\mathrm{J}_{\text {Ic }} \quad: 121 \mathrm{~kJ} / \mathrm{m}^{2} \quad$ (10 Data)

Exponent $\mathrm{n}: 0.29$
Fit Coeff. R : 0.923 
Table B8. Fracture toughness data for specimen $85-\mathrm{XB}$ in air at $289^{\circ} \mathrm{C}$.

$\begin{array}{llll}\text { Test Number } & : \text { JRI-35 } & \text { Test Temp. } & : 289^{\circ} \mathrm{C} \\ \text { Test Environment } & : \text { Air } & \\ \text { Material Type } & : \text { Type 304 SMA Weld HAZ } & \text { Heat Number }: 10285 \\ \text { Aging Temp. } & :- & \text { Aging Time } & :- \\ \text { Irradiation Temp. } & : 297^{\circ} \mathrm{C} & \text { Fluence } & : 1.44 \times 10^{21} \mathrm{n} / \mathrm{cm}^{2}(2.16 \mathrm{dpa}) \\ \text { Thickness } & : 6.523 \mathrm{~mm} & \text { Net Thickness } & : 5.664 \mathrm{~mm} \\ \text { Width } & : 11.944 \mathrm{~mm} & \text { Flow Stress } & : 725 \mathrm{MPa} \\ \text { Modulus E } & : 175 \mathrm{GPa} & \text { Effective Flow Stress } & : 527 \mathrm{MPa} \\ \text { Initial Crack } & : 6.442 \mathrm{~mm} & \text { Init. a/W } & : 0.539 \\ \text { Final Crack } & : \text { not measured } & \text { Final a/W } & :\end{array}$

\begin{tabular}{|c|c|c|c|c|}
\hline No. & Load $(\mathrm{kN})$ & Deflection $(\mathrm{mm})$ & $\mathrm{J}\left(\mathrm{kJ} / \mathrm{m}^{2}\right)$ & $\Delta \mathrm{a}(\mathrm{mm})$ \\
\hline 0 & 0.000 & 0.000 & 0.00 & 0.000 \\
1 & 0.726 & 0.040 & 1.00 & 0.000 \\
2 & 1.658 & 0.058 & 2.31 & 0.001 \\
3 & 2.434 & 0.084 & 5.86 & 0.003 \\
4 & 3.083 & 0.127 & 13.98 & 0.007 \\
5 & 3.721 & 0.174 & 25.06 & 0.013 \\
6 & 4.282 & 0.234 & 41.26 & 0.053 \\
7 & 4.777 & 0.298 & 60.43 & 0.101 \\
8 & 5.128 & 0.380 & 88.22 & 0.151 \\
9 & 5.310 & 0.448 & 111.84 & 0.200 \\
10 & 5.305 & 0.528 & 141.05 & 0.247 \\
11 & 5.423 & 0.548 & - & - \\
\hline
\end{tabular}

Crack extension determined from DC potential drop method.

\section{Power-Law Fit $\quad \mathbf{J}=\mathbf{C}(\Delta \mathbf{a})^{\mathrm{n}}$}

$\mathrm{J}$-R curve not determined because of uncontrolled crack advance at $\mathrm{J}=141 \mathrm{~kJ} / \mathrm{m}^{2}$. 
Table B9. Fracture toughness data for specimen GG6T-B in air at $289^{\circ} \mathrm{C}$.

$\begin{array}{llll}\text { Test Number } & : \text { JRI-36 } & \text { Test Temp. } & : 289^{\circ} \mathrm{C} \\ \text { Test Environment } & : \text { Air } & & \\ \text { Material Type } & : \text { Type 304L SAWeld HAZ Heat Number } & : \text { Grand Gulf core shroud shell } \\ \text { Aging Temp. } & :- & \text { Aging Time } & :- \\ \text { Irradiation Temp. } & : 297^{\circ} \mathrm{C} & \text { Fluence } & : 1.44 \times 10^{21} \mathrm{n} / \mathrm{cm}^{2}(2.16 \mathrm{dpa}) \\ \text { Thickness } & : 6.543 \mathrm{~mm} & \text { Net Thickness } & : 5.728 \mathrm{~mm} \\ \text { Width } & : 11.993 \mathrm{~mm} & \text { Flow Stress } & : 711 \mathrm{MPa} \\ \text { Modulus E } & : 175 \mathrm{GPa} & \text { Effective Flow Stress } & : 502 \mathrm{MPa} \\ \text { Initial Crack } & : 6.426 \mathrm{~mm} & \text { Init. a/W } & : 0.536 \\ \text { Final Crack } & : 9.833 \mathrm{~mm} & \text { Final a/W } & : 0.820\end{array}$

\begin{tabular}{|c|c|c|c|c|}
\hline No. & Load $(\mathrm{kN})$ & Deflection $(\mathrm{mm})$ & $\mathrm{J}\left(\mathrm{kJ} / \mathrm{m}^{2}\right)$ & $\Delta \mathrm{a}(\mathrm{mm})$ \\
\hline 0 & 0.0000 & & 0.0 & 0.000 \\
1 & 1.283 & 0.022 & 0.9 & 0.000 \\
2 & 2.195 & 0.056 & 4.8 & 0.001 \\
3 & 3.102 & 0.101 & 12.6 & 0.003 \\
4 & 3.794 & 0.145 & 22.8 & 0.008 \\
5 & 4.258 & 0.210 & 40.3 & 0.051 \\
6 & 4.792 & 0.274 & 60.4 & 0.045 \\
7 & 5.113 & 0.354 & 84.8 & 0.158 \\
8 & 4.952 & 0.467 & 120.9 & 0.281 \\
9 & 4.618 & 0.564 & 144.7 & 0.512 \\
10 & 4.182 & 0.659 & 163.9 & 0.757 \\
11 & 3.854 & 0.738 & 176.6 & 0.985 \\
12 & 3.635 & 0.805 & 191.0 & 1.095 \\
13 & 3.351 & 0.883 & 200.8 & 1.298 \\
14 & 3.179 & 0.961 & 209.4 & 1.492 \\
15 & 3.028 & 1.036 & 219.3 & 1.647 \\
16 & 2.786 & 1.134 & 229.3 & 1.857 \\
17 & 2.286 & 1.281 & 225.6 & 2.248 \\
18 & 1.883 & 1.447 & 215.7 & 2.691 \\
19 & 1.635 & 1.599 & 211.0 & 3.096 \\
20 & 1.501 & 1.740 & 3.407 \\
\hline
\end{tabular}

Crack extension determined from DC potential drop method.

Power-Law Fit

DC Potential Method

Coeff. C $\quad: 186 \mathrm{~kJ} / \mathrm{m}^{2}$

$$
\mathbf{J}=\mathbf{C}(\Delta \mathbf{a})^{\mathrm{n}}
$$

$\mathrm{J}_{\text {Ic }} \quad: 125 \mathrm{~kJ} / \mathrm{m}^{2} \quad$ (11 Data)

Exponent $n \quad: 0.29$
Fit Coeff. R : 0.757 
Table B10. Fracture toughness data for specimen $75-11 \mathrm{TT}$ in high-purity water at $289^{\circ} \mathrm{C}$.

Test Number : CGRI JR-33 Test Temp. $\quad: 289^{\circ} \mathrm{C}$

Test Environment : High-purity water with $\approx 400 \mathrm{ppb}$ dissolved oxygen

Material Type :CF-8M Heat Number :75

Aging Temp. $\quad: 400^{\circ} \mathrm{C}$

Aging Time $\quad: 10,000 \mathrm{~h}$

Irradiation Temp. : $297^{\circ} \mathrm{C}$

Thickness $\quad: 6.515 \mathrm{~mm}$

Fluence $\quad: 1.63 \times 10^{21} \mathrm{n} / \mathrm{cm}^{2}(2.46 \mathrm{dpa})$

Width $\quad: 12.022 \mathrm{~mm}$

Net Thickness $\quad: 5.685 \mathrm{~mm}$

Modulus E $\quad: 170 \mathrm{GPa}$

Initial Crack $\quad: 6.338 \mathrm{~mm}$

Flow Stress $\quad: 760 \mathrm{MPa}$ (Estimated)

Final Crack $\quad: 9.626 \mathrm{~mm}$

Effective Flow Stress : $585 \mathrm{MPa}$ (Estimated)

Init. a/W $\quad: 0.527$

Final a/W : 0.801 (Measured)

\begin{tabular}{|c|c|c|c|c|}
\hline No. & Load $(\mathrm{kN})$ & Deflection $(\mathrm{mm})$ & $\mathrm{J}\left(\mathrm{kJ} / \mathrm{m}^{2}\right)$ & $\Delta \mathrm{a}(\mathrm{mm})$ \\
\hline 0 & 0.000 & 0.000 & 0.0 & 0.000 \\
1 & 1.0206 & 0.0606 & 2.1 & 0.001 \\
2 & 1.7444 & 0.0845 & 4.2 & 0.002 \\
3 & 2.3543 & 0.1203 & 9.1 & 0.005 \\
4 & 2.9476 & 0.1635 & 16.8 & 0.008 \\
5 & 3.4982 & 0.2100 & 26.7 & 0.033 \\
6 & 3.9856 & 0.2582 & 38.5 & 0.074 \\
7 & 4.3593 & 0.3225 & 55.8 & 0.140 \\
8 & 4.5293 & 0.4026 & 77.4 & 0.275 \\
9 & 4.2455 & 0.5370 & 108.9 & 0.600 \\
10 & 2.7523 & 0.7904 & 131.0 & 1.555 \\
11 & 2.1877 & 0.9025 & 127.5 & 2.146 \\
12 & 2.0009 & 0.9724 & 134.7 & 2.310 \\
13 & 1.8502 & 1.0371 & 135.0 & 2.548 \\
14 & 1.5426 & 1.1759 & 154.1 & 2.698 \\
15 & 1.3853 & 1.2950 & 165.9 & 2.837 \\
16 & 1.2231 & 1.4167 & 168.6 & 3.065 \\
17 & 1.1405 & 1.4781 & 160.4 & 3.288 \\
\hline
\end{tabular}

Power-Law Fit

DC Potential Method

Coeff. C $\quad: 120 \mathrm{~kJ} / \mathrm{m}^{2}$
$\mathrm{J}=\mathrm{C}(\Delta \mathrm{a})^{\mathrm{n}}$

$\mathrm{J}_{\mathrm{Ic}} \quad: 84 \mathrm{~kJ} / \mathrm{m}^{2} \quad$ (10 Data)

Exponent $\mathrm{n} \quad: 0.24$
Fit Coeff. R : 0.709 
Table B11. Fracture toughness data for specimen $75-11 \mathrm{TM}$ in high-purity water at $289^{\circ} \mathrm{C}$.

Test Number $\quad:$ CGRI JR-34 Test Temp. $\quad: 289^{\circ} \mathrm{C}$

Test Environment : High-purity water with $\approx 400 \mathrm{ppb}$ dissolved oxygen

Material Type : CF-8M

Aging Temp. $\quad: 400^{\circ} \mathrm{C}$

Heat Number $\quad: 75$

Irradiation Temp. : $3297^{\circ} \mathrm{C}$

Aging Time $\quad: 10,000 \mathrm{~h}$

$\begin{array}{ll}\text { Thickness } & : 6.502 \mathrm{~mm} \\ \text { Width } & : 12.012 \mathrm{~mm} \\ \text { Modulus E } & : 170 \mathrm{GPa} \\ \text { Initial Crack } & : 6.384 \mathrm{~mm} \\ \text { Final Crack } & : 9.400 \mathrm{~mm}\end{array}$

Fluence $\quad: 1.63 \times 10^{21} \mathrm{n} / \mathrm{cm}^{2}(2.46 \mathrm{dpa})$

Net Thickness $\quad: 5.702 \mathrm{~mm}$

Flow Stress $\quad: 760 \mathrm{MPa}$ (Estimated)

Effective Flow Stress : $585 \mathrm{MPa}$ (Estimated)

Init. a/W : 0.531

Final a/W $\quad: 0.783$ (Measured)

\begin{tabular}{|c|c|c|c|c|}
\hline No. & Load $(\mathrm{kN})$ & Deflection $(\mathrm{mm})$ & $\mathrm{J}\left(\mathrm{kJ} / \mathrm{m}^{2}\right)$ & $\Delta \mathrm{a}(\mathrm{mm})$ \\
\hline 0 & 0.000 & 0.000 & 0.0 & 0.000 \\
1 & 0.8584 & 0.0531 & 1.5 & 0.001 \\
2 & 1.4541 & 0.0907 & 4.5 & 0.002 \\
3 & 2.0252 & 0.1287 & 8.9 & 0.005 \\
4 & 2.5912 & 0.1725 & 15.5 & 0.070 \\
5 & 3.1271 & 0.2163 & 23.5 & 0.146 \\
6 & 3.5783 & 0.2749 & 36.0 & 0.241 \\
7 & 3.7969 & 0.3269 & 48.3 & 0.329 \\
8 & 3.7874 & 0.3923 & 63.5 & 0.470 \\
9 & 3.1409 & 0.5099 & 84.4 & 0.835 \\
10 & 2.4692 & 0.6285 & 94.6 & 1.352 \\
11 & 2.3553 & 0.6780 & 100.3 & 1.501 \\
12 & 2.1794 & 0.7470 & 107.3 & 1.697 \\
13 & 1.5461 & 0.8658 & 109.6 & 2.157 \\
14 & 1.4229 & 0.9311 & 113.1 & 2.318 \\
15 & 1.2923 & 1.0225 & 118.1 & 2.508 \\
16 & 1.2152 & 1.1085 & 122.4 & 2.672 \\
17 & 1.0075 & 1.2352 & 120.4 & 3.016 \\
\hline
\end{tabular}

Power-Law Fit

DC Potential Method

Coeff. C $\quad: 80 \mathrm{~kJ} / \mathrm{m}^{2}$
$\mathrm{J}=\mathrm{C}(\Delta \mathrm{a})^{\mathrm{n}}$

$\mathrm{J}_{\mathrm{Ic}} \quad: 40 \mathrm{~kJ} / \mathrm{m}^{2} \quad$ (12 Data)

Exponent $\mathrm{n} \quad: 0.45$
Fit Coeff. $\mathrm{R} \quad: 0.959$ 
This page is intentionally left blank.

B-12 
